\title{
THE EFFECT OF RADIUM RADIATIONS ON THE DEVELOPMENT OF CHÆTOPTERUS.
}

\author{
CHARLES PACKARD.
}

INTRODUCTION.

The experiments described in this paper show that the egg of Chcetopterus, if radiated for an appropriate length of time before insemination will be injured to such an extent that its nucleus plays no part in development. Nevertheless the sperm nucleus divides normally; development is therefore androgenetic. The history of the egg nucleus from the time of insemination until it is absorbed into the protoplasm can be followed in detail.

Similar experiments have been performed by Gunther Hertwig ('I I) on the frog's egg. He observed that if the eggs, after a brief radiation, were inseminated with fresh frog sperm, the amount of injury appearing in the embryos is proportional to the length of exposure. But if the eggs are radiated for more prolonged periods, cleavage becomes fairly normal, and the embryos, somewhat retarded in their rate of development, grow into swimming larvæ. These larvæ are normal in shape but are smaller than the controls and not as active, in these respects resembling parthenogenetic larvæ. He also observed that the nuclei of the cells in the embryos developing from eggs radiated for considerable periods are about one half of the size of the nuclei found in the controls. Since the size of the nucleus, according to Boveri, varies with the number of chromosomes contained in it, the inference is that these embryos have developed under the influence of the sperm nucleus and are therefore androgenetic. The egg nucleus has been entirely prevented from taking part in development. Cytological proof of this critical point was lacking.

The experiments of Paula Hertwig ('I6) on the eggs of Triton do not wholly confirm the results just described. Exposures of the eggs for 5 to 30 minutes to a preparation of $5 \mathrm{I} \mathrm{mg}$. of radium 
bromide, previous to insemination, resulted in embryos which were both normal and abnormal. In general there was little difference between the results obtained from the short and from the long exposures. Measurements of the nuclei in the radiated embryos showed that they were approximately one half the normal size and the development was presumably androgenetic. The actual number of chromosomes could not be counted with certainty. Hertwig states that "a certain answer to this question (of the exact number of chromosomes) could be furnished only by a study of the eggs during their early development. Since this is impossible, owing to practical difficulties which the material presents, the question must remain unsolved."

In the reverse experiment, in which frog sperm was radiated, it was found by Gunther Hertwig ('II) that the same developmental conditions obtained which he found when the egg was radiated. Normal eggs fertilized by sperm which had been radiated for short periods gave rise to abnormal embryos. But if the sperm is radiated for a long period the embryos developed normally. Later he repeated this experiment on the sea urchin and found that although the intensely radiated spermatozoon can penetrate the normal egg it fails to develop within the egg, and brings about an abnormal type of cleavage. The egg nucleus may divide by itself, sometimes normally, but more often irregularly, as though the sperm had acted as a mechanical hindrance to orderly cleavage. When the sperm had not thus interfered in the first mitosis it usually fused with the nucleus of one of the blastomeres, thus causing abnormalities in the descendants of that cell. In all of these cases the sperm aster developed normally, the centrosome divided, and the daughter centrosomes became the centers of the first cleavage figure. This fact lead Hertwig to doubt Boveri's conception of the centrosome as a permanent cell organ, and to incline to Lillie's view that it is a result of the interaction of the sperm and the egg protoplasm.

\section{Material and Methods.}

The eggs of the tubicolous annelid, Chatopterus pergamentaceus, are ideal for the type of experiments described in this paper. They can be obtained fresh and in sufficient quantities, 
polyspermy is rare, and the control eggs develop with perfect regularity if kept under appropriate conditions. The number of chromosomes is small, the haploid number being nine, and the achromatic structures are unusually large. The most valuable feature is the fact that the unfertilized eggs, when placed in sea water, proceed in their development as far as the metaphase of the first maturation division, at which time further development ceases. Now it has been shown (Packard, 'I6) that chromatin, when in its most condensed stage at the time of the metaphase, is particularly susceptible to radium radiations. A short exposure therefore is sufficient to injure the chromatin without harming the protoplasm. This is an important point, for I have shown (Packard, 'I5) that prolonged radiations injure the protoplasm and bring about a very abnormal type of development quite different from that which follows the injury of the chromatin alone. A further advantage possessed by these eggs is their extremely labile condition. As Miss Allyn ('I2) showed, they can be stimulated to develop parthenogenetically by a great number of agents. I have found that prolonged exposures will not prevent it from developing when fertilized by a normal sperm.

The metaphase of the first maturation division in the egg of Chatopterus is reached about twenty minutes after the unfertilized eggs are put in sea water. In carrying out an experiment I allowed the eggs to remain for this period in sea water and then exposed them to the radium. A quantity of eggs is gathered into a compact mass in the center of a watch glass containing a measured quantity of water. The tube containing the radium bromide, having the strength of $50 \mathrm{mg}$. of pure bromide, is now held over the center of the mass of. eggs at a distance of $\frac{5}{16}$ inch above it. It is obvious that the eggs did not all receive exactly equal amounts of radiation, but the difference in amount which each received is very slight.

The alpha rays are not able to penetrate the thin walls of the glass tube in which the radium salt is held and are therefore not responsible for any of the effects obtained. Probably some of the slower beta rays are also cut off by the glass or by the sea water over the eggs; but the great majority of beta rays and all of the gamma rays are able to reach the eggs. 
The unfertilized eggs were exposed for periods varying from 5 to 135 minutes, after which they were inseminated with Chatopterus sperm, and their behavior in the formation of polar bodies and in cleavage recorded. In all of these experiments controls were kept, made up from the same lot of eggs and subject to the same temperature conditions.

For cytological study the radiated eggs were killed, at various times after insemination, in Meves' fluid, Boveri's picro-acetic, and in Bouin's fluid. The last named reagent proved to be the best for most purposes. It acts rather destructively on the centrospheres, but is otherwise very good.

\section{The Normal Development of Chrotopterus.}

The process of maturation and fertilization in Chcetopterus has been described by Mead ('97). When the eggs are taken from the genital segments of the female and put into sea water the wall of the germinal vesicle breaks down. Fibers from two welldeveloped egg asters grow in toward the chromosomes which gradually assume an equatorial position. The spindle thus established moves toward the animal pole, rotating as it goes, until it comes to rest at right angles to the periphery of the egg. The chromosomes are already split, being tetrads at this time, but no actual separation occurs until after the sperm has penetrated the egg. In this condition the egg remains until fertilized.

As soon as the sperm has penetrated the egg the first polar body is quickly extruded, about 15 minutes after insemination. The second polar body is given off about io minutes later. Each chromosome remaining within the egg bends into a $\mathrm{V}$ shape and the entire group of nine gathers about the remaining egg aster. Before the group begins to move inward toward the center of the egg each chromosome becomes vesicular. During the inward journey the separate vesicles fuse to form a single large egg nucleus. The egg aster disappears when the fusion of the chromosomal vesicles takes place.

The sperm head does not begin to grow until it has penetrated the egg for some distance. But before its growth commences a small sperm aster with a centrosome appears in front of it. As the sperm moves inward the centrosome divides, each daughter 
centrosome being surrounded by a well-marked aster. Finally the sperm grows into a vesicular form resembling the egg vesicle with which it soon comes in contact. Actual mingling of the chromatin elements does not occur until the metaphase of the first cleavage. Up till that time the chromosomes from each nucleus can easily be distinguished. Before the chromosomes have condensed into their characteristic shape there can be seen in the cleavage nucleus a number of chromatin nucleoli, probably derived from the chromosomes. During cleavage these lag behind, staying in the cleavage plane. The achromatic stuctures are very prominent, the asters remaining even after the completion of cleavage.

\section{Observations on the Living EgGs.}

To test the effect which gradually increasing amounts of radiation will produce in the rate of cleavage and in the production of abnormal cleavages it is necessary to employ throughout any one experiment eggs taken from a single female, for it was found that eggs from different specimens varied in the rate of cleavage and in other ways. In each experiment a sufficient quantity of eggs was exposed, and from this number a few were taken off at Iominute intervals and fertilized in finger bowls. The proportion of cleaving eggs, compared with the controls, and the number of abnormal cleavages were recorded. This experiment was repeated on different days, and with eggs derived from different females.

It was found that brief radiations do not affect the rate at which the polar bodies are extruded. Indeed, prolonged radiations have little effect, for only in a few instances could any unusual condition be found. A cytological study showed that as long a treatment as 80 minutes causes very few abnormal polar divisions. Cleavage is much retarded, the most pronounced retard being seen in eggs radiated for 30 to 40 minutes previous to insemination. Longer exposures result in a more normal rate. This unexpected result is due to the fact that eggs which have been radiated for a long time are almost all polyspermic and such eggs always divide rapidly, sometimes ahead of the controls, and always into three or more parts. 
The significant feature in these experiments is the sudden drop in the rate of cleavage seen in eggs radiated for periods up to 40 minutes. The explanation for this phenomenon is to be found in the behavior of the egg nucleus during maturation and subsequent growth, and in the behavior of the sperm nucleus during cleavage.

\section{Cytological Observations.}

A cytological examination of eggs exposed for periods of 15 to 35 minutes previous to insemination shows that the first effect of the radium radiations is on the chromatin; the protoplasm is not visibly affected. The abnormal behavior of the egg nucleus is perfectly apparent, but even prolonged radiation produces no visible change in the protoplasm. Without doubt the latter is affected, for polyspermy becomes more and more common as the duration of the exposure is lengthened. In Nereis, polyspermy under these conditions is due to a weakening of the egg membrane and perhaps to a partial liquefaction of the protoplasm. The same explanation may hold true for Chetopterus also.

All the eggs exposed for periods up to 35 minutes show the same types of abnormalities but in varying degrees, the more pronounced being found naturally in eggs exposed for the longer periods. The outstanding feature in the development of these eggs is the ever increasing tendency of the germ nuclei to remain apart. This is not due to any unusual development of the sperm; its centrosome divides normally, the asters appear, and the whole apparatus moves inward at the usual rate (Fig. I). But the egg nucleus often remains close under the region of the polar bodies and may even be connected with them by a protoplasmic bridge in which chromatin threads can be distinguished. This phenomenon grows more common as the duration of the exposure is increased to 35 minutes. In this position it develops more or less normally, depending on the length of exposure. During cleavage the egg chromatin always remains separate from the dividing sperm chromosomes and can easily be distinguished from them because of its position and appearance. With this brief statement of the general course of development in the radiated eggs we may now examine in detail some of the conditions found during the various stages of maturation and cleavage. 
After the sperm enters, the first maturation is completed normally and the chromosomes become arranged on the second polar spindle. There are very few exceptions to this, even in eggs exposed for a long time. Fig. 2 shows a condition which may be found occasionally in eggs treated for 80 minutes or more. It is evident that the whole egg, both chromatin and protoplasm, has been greatly disturbed, for the sperm after entrance has failed to develop normally. In the course of normal development it grows into a large vesicle by the time it has reached the vicinity of the egg nucleus, but in this case there is no evidence of any such growth. The tripolar spindle of the first maturation division indicates again how extensive is the injury to the egg. The extra aster may be derived from the sperm aster, or possibly both sperm asters are involved, one having fused with the egg aster; or the latter may have divided, while the sperm aster has not developed at all. The latter view is very likely correct for in other eggs similarly treated the sperm may be seen lying in the center of the egg without any trace of centrosome or asters. Whatever may be the right interpretation it is evident that the egg protoplasm has been injured to such an extent that the sperm cannot develop normally. The same phenomenon can be seen in the eggs of Nereis similarly treated. The chromosomes on the tripolar spindle show no signs of fragmentation but they have not divided, and some of them are irregular in shape. But in eggs treated up to 45 minutes the formation of the polar bodies and the development of the sperm is practically normal. The egg nucleus in a fairly large proportion of cases develops normally after the extrusion of the polar bodies and fuses with the sperm nucleus. The subsequent development of such eggs will be described later.

In a considerable number of eggs exposed for periods up to 45 minutes the egg nucleus does not behave normally. Instead of moving inward to meet the advancing sperm, it tends to remain in its original position under the polar bodies, there developing into the vesicular stage. Fig. 3 illustrates this condition. Here, although a part of the nucleus has moved inward, there still remains a part of it directly under the polar bodies, connected with the rest by a protoplasmic bridge. The distribution of the chro- 
matin follows the shape of the nuclear vesicle; a little is still in the polar position. This condition prevents the egg nucleus from flattening out against the sperm nucleus. The latter is seen normally developed with its astral rays extending far out into the protoplasm.

A more pronounced case of the same sort is seen in Fig. 4. Here the egg nucleus has hardly moved at all but has developed in approximately its original position. Its inner end has come under the influence of a sperm aster, and some of its chromatin is evidently polarized. Its outer end is attached to the second polar body by chromatin threads and the whole nucleus has the appearance of being anchored to it.

Modifications of this condition are seen in the polyspermic egg shown in Fig. 5. Most of the egg nucleus has migrated away from the pole but a small piece about the size of a single chromosomal vesicle is still attached to the second polar body by delicate strands. Two sperms have entered; one of them has entirely fused with the egg nucleus, and the other is about to fuse. Only three asters can be found in this case. In Fig. 6 two sperms have fused with the egg nucleus which, as in the preceding case, is still attached to the polar body. Five asters can be found in connection with this cleavage nucleus. The number of instances in which three or five asters appear make it evident that the original egg aster may persist.

A final stage showing how the egg nucleus in the vesicular condition may fail to fuse normally with the sperm nucleus appears in Fig. 7. The latter nucleus is about fully grown and its asters are well developed. The egg nucleus is developed only in part. The two small vesicles contain numerous chromatin granules. Between them the remainder of the egg chromatin lies free in the protoplasm in the form of rods and spheres. These masses are not chromosomes for they have not the typical size or appearance. The curious positions which they have assumed indicate that the force drawing them inward is not normal.

Those eggs which were radiated for periods up to 25 minutes do not show many of the abnormalities just described. In such eggs the pronuclei develop normally to all appearance and fuse with each other. The first indication that any injury has been 
done to the egg chromatin appears at the anaphase of the first cleavage. Fig. 8 shows an egg in which this is the case. There has not been a complete mingling of the two nuclei for the egg chromosomes are left behind in the future cleavage plane. They are for the most part normal in appearance. One is stretched out to an unusual length as though pulled at each end by a spindle fiber. If this is the case, the spindle-fiber attachment is unusual for here it is evidently terminal while in the normal chrcmosomes it is median. The nine sperm chromosomes in each group show the characteristic V-shape. Division is thus regular and haploid, and the injured egg chromosomes have not interfered with the orderly division of the egg.

A more noticeable injury to the egg chromatin is seen in Fig. 9. Here again the nuclei probably fused normally to all appearances. But at the anaphase, when the sperm chromosomes are moving towards the poles, the egg chromatin is left behind in a very confused condition. A few chromosomes have formed but they are noticeably beaded as though on the point of breaking up into fine granules. The remainder of the chromatin is in irregular masses. Possibly its position outside of the spindle accounts for the fact that the chromosomes show little sign of being drawn towards the poles. No spindle fibers can be found attached to it.

When the nuclei have failed to fuse, as shown in Figs. 3 and 4, the further growth of the egg nucleus is greatly modified. In Fig. Io the chromatin is seen to be condensed into rods and irregular masses which lie wholly outside of the mitotic spindle. The rod-shaped masses are beaded. Only a few of the chromosomal vesicles could have migrated inward.

A polyspermic egg in which the same type of abnormality is found is shown in Fig. II. From the distribution of the chromatin it may be inferred that this condition is a further development of such an egg as is shown in Figs. 5 and 6. It is interesting to note that the egg chromatin which shows the greatest sign of injury remains nearest to the pole. The more normal chromatin has migrated inwards. The sperm chromosomes which are distributed very irregularly are of normal shape and size.

These observations show that when the unfertilized eggs are radiated for periods up to 30 minutes before insemination, the 
nucleus develops normally and fuses with the sperm nucleus. But during cleavage the egg chromosomes do not move together with the sperm chromosomes but lag behind in the future cleavage plane. Under the influence of longer radiations the egg is so affected that its nucleus is unable to move from its position under the polar bodies, but develops there more or less abnormally, and plays no part in the cleavage of the egg. In both cases the cleavage is regular and haploid. A prolonged radiation so affects the egg that the polar bodies may be formed abnormally or not at all; in such instances the sperm also fails to develop, though it can move up to the position of the polar spindle. Polyspermy becomes more and more frequent as the duration of exposure increases. This leads to abnormal cleavage in to three or more cells.

\section{Discussion.}

The facts presented in the foregoing pages show that with increasing periods of exposure the number of diploid cleavages is lessened and the number of haploid cleavages, in which only the sperm nucleus takes part, is greatly augmented. Actual counts of sections of dividing eggs give a clear picture of the proportion which obtains between these two types. These counts are represented graphically in the accompanying text figure. The ordinates represent the percentage of eggs which cleave, and the abscissæ, the duration of the exposure in minutes. Polyspermic eggs were disregarded in making these counts because they belong to a different category of phenomena. The dotted line represents the percentage of eggs which divided regularly.

It is seen that brief exposures do not prevent eggs from dividing, but that exposures of 30 to 35 minutes bring about a marked decrease in the numbers which cleave. This relation was noticed in the living eggs, and the curve plotted from the latter data corresponds closely to that derived from a study of the sections. After this critical period the number of eggs which cleave regularly increases to about 70 per cent. and then, with prolonged exposures, gradually falls off until, after an exposure of I30 minutes, practically no eggs divide.

The other curves show why this sudden drop at the critical 
period occurs. The number of eggs dividing with the full complement of chromosomes falls gradually up to the 30-minute period. Then it drops very suddenly so that after a treatment of 35 to 40 minutes very few eggs divide with the diploid number.

The proportion of eggs dividing wholly under the influence of the sperm rises rapidly at the critical period and remains high until prolonged radiation prevents cleavage altogether. Of the eggs which remain uncleft after the others have divided with either the diploid or the haploid number of chromosomes, most are in the condition shown in Fig. 9. These may divide at a much later time but I have no data on that point. It is evident, therefore, that during the critical period the egg nucleus has been injured to such an extent that it can take no part in cleavage, and in some way prevents or gr eatly retards the cleavage of the sperm nucleus. After that time it acts like a foreign body, exerting very little influence, if any at all.

The form of the curve shown in the dotted line of the text figure bears a striking resemblance to the curves figured by Hertwig ('I I) in his article on the effect of radiations upon the unfertilized frog egg. In his experiments Hertwig exposed different lots of eggs to preparations of radium of different strengths, and then fertilized them with normal sperm. The criterion in estimating the effect of the treatment was the length of life of the embryos. In the three sets of experiments it appeared that with brief exposures the length of embryonic life varies inversely with the duration of the exposure. Thus, the eggs treated for 5 minutes before insemination with a preparation having the strength of $7.4 \mathrm{mg}$. of $\mathrm{RaBr}_{2}$ lived for 5 days, at which age they were abnormal in many respects. An exposure of 15 minutes resulted in much greater injuries, and the embryos lived but 3 days. But with longer radiation, development was normal through the gastrula stage and the embryos lived 8 or 9 days. They were weak and small but fairly well formed. With weaker preparations of radium the results were less pronounced but of the same order.

Hertwig's explanation is that brief radiations injure the egg nucleus but do not prevent it from fusing with the sperm nucleus. However, the injury is sufficient to bring about the production of 
abnormal nuclei in the later embryos, as he demonstrated cytologically. The longer exposures so injured the egg nucleus that it failed altogether to fuse with the sperm nucleus, and therefore played no part in later development. The embryos were therefore androgenetic.

He has brought forward no actual proof that this is the case in the frog egg, except the evidence furnished by measurements of the nuclei. Paula Hertwig has shown that when Triton eggs are similarly treated the number of chromosomes is less than the diploid number and probably the haploid number but of this she is not certain. But Hertwig's explanation is in part supported by the facts brought forward in this paper. A strict comparison cannot be made since his conclusions were based on the length of life of the embryos while mine have to do with the behavior of the germ nuclei up to the time of the first cleavage. But in all probability the same phenomena occur in both cases.

The results obtained in the reverse experiment, in which the frog sperm is first radiated and then added to fresh eggs, are of the same order as the foregoing. Up to a critical time the radiated sperm produces greater and greater abnormalities in the embryo; after that period, more intensely radiated sperm produces more normal embryos. The original experiment of $\mathrm{O}$. Hertwig ('II) has been repeated by G. Hertwig ('I2), Opperman ('I3) and others with the same results. A cytological study of the eggs of the sea-urchin fertilized by radiated sperm has been made by G. Hertwig ('I2). He found that after prolonged radiation the sperm retained their motility and entered the egg, but the sperm nucleus never increased to its normal size in the egg. As a rule it lay as a foreign body outside of the dividing egg nucleus, but occasionally it became involved in the spindle and the division was rendered abnormal, probably because of the mechanical interference. In such instances the sperm nucleus was carried passively into one of the blastomeres later fusing with the nucleus of that cell. The subsequent development of the cell and its descendants was abnormal. On the other hand, a shorter radiation injured the sperm nucleus but it fused with the egg nucleus. Later it was thrown out as in Chetopterus. In such instances the egg nucleus divided abnor mally and cleavage 
was irregular. Hertwig states that the abnormalities of the egg chromosomes are produced by the action of the injured sperm chromatin which operates like a poison. Its decomposition products in some way communicate the poison to the sound chromatin.

There is no evidence, other than that given by Hertwig, that radiated chromatin acts as a poison to the unradiated nucleus. His figures in support of this idea are not convincing; they can be explained more readily on the assumption that the injured chromatin acts merely as a mechanical hindrance in those instances in which it is actually caught in the cleavage spindle. It is difficult to imagine how disintegrating chromatin can communicate its injury to sound chromatin. The idea is apparently drawn from O. Hertwig's theory that the radiation produces a "contagium vivum" which acts in a manner similar to the poison elaborated by a pathogenic bacterium. Such an assumption has no basis in fact and does not explain the observed phenomena.

The cytological studies of Paula Hertwig on the eggs of Triton and the frog, and of Opperman on the trout, indicate that whatever effect the radiated chromatin produces in the division of the unradiated nucleus is due to mechanical interference. Such effects can best be seen when the radiated and sound nuclei actually fuse prior to the formation of the chromosomes. The radiated chromatin is eliminated from the spindle and causes a derangement in the spindle if it lies near enough to it. In Chatopterus the chromosomes form before the fusion of the nuclei and there is no evidence that any such interference occurs.

There is always a noticeable variation in the extent of injury produced by the radiations on a single lot of eggs. The curves shown in the text figure indicate that after the critical length of exposure, when the egg nucleus is greatly injured in the majority of cases, there are still some eggs which develop normally with the diploid number of chromosomes. This variation may be due to the fact that the eggs were not equally exposed, or that some are more resistant than others. The latter is probably the case. Paula Hertwig ('I6) showed that when Triton eggs are exposed for a definite period some develop normally and some abnormally. The normal eggs in certain instances showed the 
diploid number of chromosomes. Her explanation for this phenomenon is that the normal sperm chromosomes divided to form the diploid number at some time before the first cleavage. There is no evidence to prove this point. More probably the egg was not radiated sufficiently and the nucleus was comparatively uninjured so that it fused with the sperm nucleus and the subsequent cleavage was normal.

That sperms show varying resistance was shown by Gunther and Paula Hertwig ('I3). When methylene blue is allowed to act

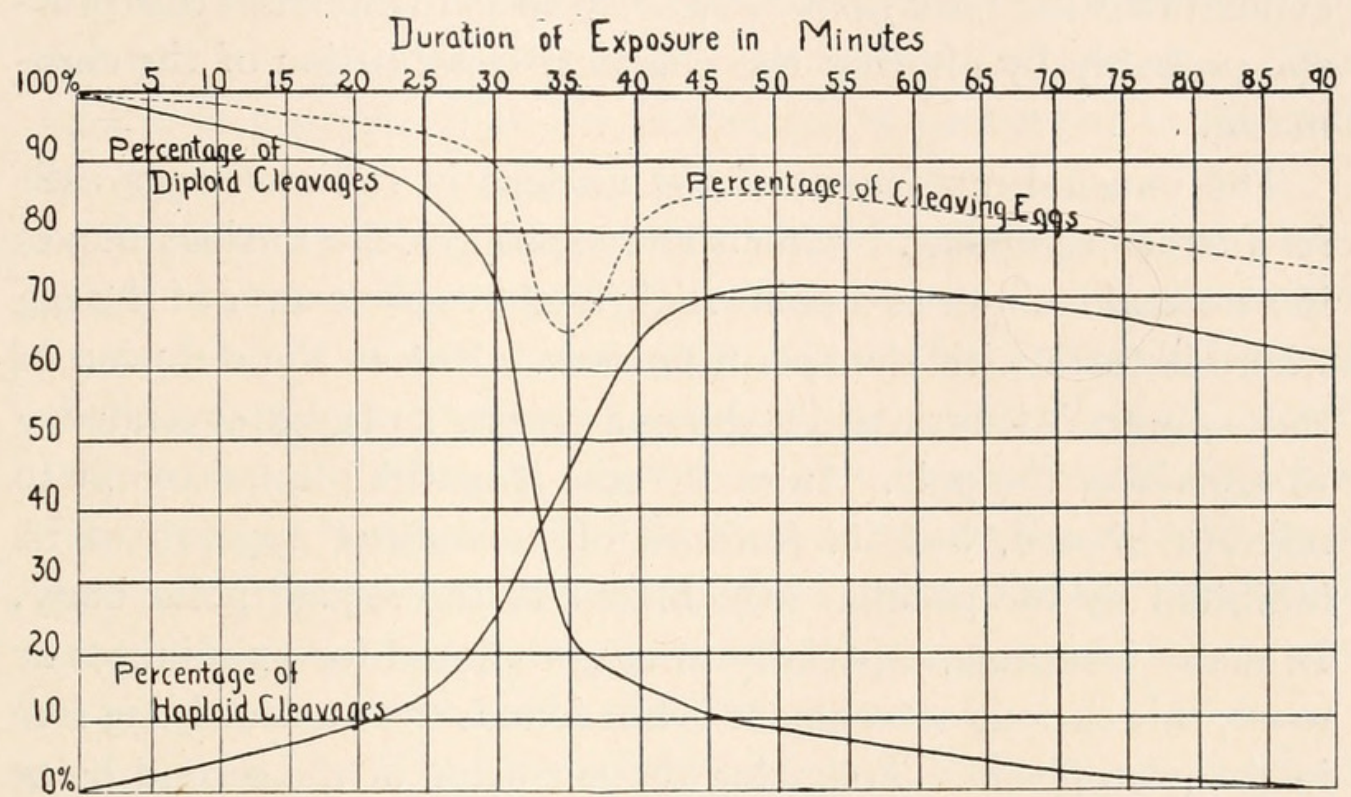

TEXT Figure i.

for I 8 hours on sperm from the same testis, some of the sperms are killed while others retain their motility perfectly. The same variation in susceptibility is probably found in the egg also.

Signs of injury in the chromatin do not appear until the chromatin increases in volume. The radiated sperm appears perfectly normal until it commences to grow inside of the egr. In the case of the sea-urchin it normally does not increase greatly in size until after it has fused with the egg nucleus, and it is not until that time that a radiated nucleus shows its abnormal condition. When the eggs of Chatopterus are radiated the chromosomes are in the form of tetrads, the two successive divisions of the chromatin. having already taken place. The chromosomes divide regularly and do not increase noticeably in size. Polar body formation is 
normal. It is abnormal only when the egg has been radiated so long that the protoplasm has been injured. But if the radiation is for periods up to 50 minutes, the polar bodies are well formed and the remaining chromosomes appear to be normal until they grow into the vesicular condition. The altered mode of development in such cases has already been described. If the radiation is short, that is, from 20 to 30 minutes, the chromatin does not show evidences of injury until the time of cleavage. Since chromatin grows by taking up substances from the protoplasm it is evident that the radiations have acted so as to interrupt this process, probably by altering the chemical constitution of the chromatin.

The unusual movement of the nucleus in radiated eggs calls for further comment. After short exposures the nucleus moves in a normal manner to a point slightly above the center of the egg where it fuses with the sperm nucleus. But as the duration of the exposure is lengthened it shows a greater and greater tendency to remain at the pole. In every case it makes some attempt to migrate inward, but its freedom of movement appears to be inhibited by the peculiar attachment to the second polar body. In many instances, especially in eggs radiated for 35 minutes or more, this curious attachment is not found, the nucleus lying free in the protoplasm. Following the extrusion of the second polar body, a process which is normal in all respects, the remaining chromosomes become vesicular and finally fuse to form a single large vesicle, which, instead of moving toward the sperm nucleus, remains in place. The chromatin which in the course of normal development condenses into chromosomes after the two nuclei have fused here develops into irregular masses, some of which may migrate slightly; the greater number do not. That chromatin which moves furthest from the pole is most normal in appearance.

Why does the egg nucleus fail to travel toward the center of the egg? The egg protoplasm has not been visibly injured; indeed it appears to be perfectly normal for it can draw in the sperm and the latter moves at the usual rate up to the center of the egg. In both monospermic and polyspermic eggs there is evidence that extensive protoplasmic movements are taking place for the yolk 
spheres are pushed away from the advancing sperm so that the latter lies in an area of clear protoplasm. In respect to the sperm, therefore, the egg protoplasm reacts normally. Only the egg nucleus fails to migrate. As the duration of exposure increases the nucleus moves a shorter and shorter distance. In other words, the greater the injury to the chromatin, the smaller is the distance through which it moves. This is shown in Fig. II. The egg nucleus under the polar bodies has formed into chromosomes and chromatin masses, of which the most abnormal in appearance is still in its original position while the rest have moved down to a position normally occupied by the egg nucleus at this stage. This condition suggests that the chromatin is concerned in its own movement.

This idea is supported by the behavior of the radiated chromatin shown in Figs. 8 and 9. In Fig. 8 the radiated chromatin in the form of chromosomes is left behind during the division of the sperm nucleus. One chromosome is normal in appearance but the spindle fiber attachment is abnormal; instead of being median it is terminal. In this instance there is an ineffectual attempt at movement. In Fig. 9 no spindle fibers are found attached to the irregular masses of egg chromatin, and the masses do not move with the sperm chromosomes.

According to Chambers ('I7) the spindle fibers are lines of stress or of protoplasmic flow; they are not formed structures. As such they are probably produced as a result of the interaction of the chromosomes on the egg protoplasm. When the chromatin is rendered abnormal by the radiations it fails to stimulate their production and therefore does not move with the sperm chromosomes to which spindle fibers are attached. If the fibers develop under the influence of the chromosomes, there is no need to assume the presence of contractile fibers in the protoplasm which serve to pull the chromosomes toward the poles. They are not bodies which are passively pulled about in the cell, but are actively concerned in their own movement.

\section{SUMMARY.}

I. Radiation of the unfertilized eggs of Chatopterus results in injurious effects which do not become manifest until after the 
extrusion of the polar bodies, following insemination with normal sperm. That two normal mitotic divisions should intervene after radiation and only then that the injury to the chromosomes becomes apparent can be explained by the fact that the two longitudinal divisions preparatory to polar-body formation have been completed. Only when the chromosomes again "grow" in preparation for a new division do abnormal characters manifest themselves.

2. If the radiation is brief ( 20 to $30 \mathrm{~min}$.) the germ nuclei fuse normally but the radiated egg chromatin fails to form normal chromosomes. No spindle fibers develop from these abnormal chromatin masses, and they remain in the cleavage plane during mitosis. If the radiation is longer (35 to $50 \mathrm{~min}$.) the chromosomes, after the extrusion of the polar bodies, develop abnormally and fail to fuse with the sperm nucleus. In both cases the sperm nucleus divides and development is androgenetic.

3. During cleavage the most injured chromatin does not move and lacks spindle fibers. This suggests that the fibers are normally developed under the influence of the chromosomes and that the latter are concerned in their own movement.

Allyn, H. M.

\section{LITERATURE CITED.}

'I2 The Initiation of Development in Chætopterus. Biol. Bull., Vol. 24. Chambers, R.

'I7 Microdissection Studies, II. The cell aster. Journ. Exp. Zool., Vol. 23. Conklin, E. G.

'I 7 The effect of centrifugal force on the structure and development of the egg of Crefidula. Journ. Exp. Zool., Vol. 22.

\section{Herlant, M.}

'I I Etude sur les bases cytologiques du mecanisme de la parthénogénèse expérimentale chez les Amphibiens. Arch. de Biol., Tm. 28.

\section{Hertwig, G.}

'I I Radium bestrahlung unbefruchteter Froscheier. Arch. f. mikr. Anat., Bd. 77 .

'ı2 Die Schicksal des mit Radiumbestrahlten-Spermachromatin im Seeigelei. Arch. f. mikr. Anat., Bd. 77.

'I3 Parthenogenesis bei Wirbeltieren, hervorgerufene durch artfremden radiumbestrahlten Samen. Arch. f. mikr. Anat., Bd. 8I.

Hertwig, G., and P.

'I3 Beeinflussung der mannlichen Keimzellen durch chemische Stoffe. Arch. f. Mikr. Anat., Bd. 83 .

Hertwig, P.

'13 Das Verhalten des mit radiumbestrahlten Spermachromatins im Froschei. Arch. f. mikr. Anat., Bd. 8I. 


\section{EFFECT OF RADIUM ON DEVELOPMENT OF CHÆTOPTERUS. 67}

'r6 Durch Radiumbestrahlung verursachte Entwicklung von halbkernigen Triton und Fischembryonen. Arch. f. mikr. Anat., Bd. 87.

Lillie, F. R.

'o6 Observations and Experiments concerning the Elementary Phenomena of Embryonic Development in Chætopterus. Journ. Exp. Zool., Vol. I4.

Mead, A. D.

'97 The Origin and Behavior of the Centrosomes in the Annelid Egg. Journ. Morph., Vol. I4.

Opperman, $\mathbf{K}$.

'I3 Die Entwicklung.von Forelleneiern nach Befruchtung mit radiumbestrahl. ten Samenfadens. Arch. f. mikr. Anat., Bd. 83.

\section{Packard, C.}

'I4 The Effect of Radium Radiations on the Fertilization of Nereis. Journ. Exp. Zool., Vol. I6.

'I5 The Effects of the Beta and Gamma Rays of Radium on Protoplasm. Journ. Exp. Zool., Vol. I9.

'I6 The Effect of Radium Radiations on the Rate of Cell Division. Journ. Exp. Zool., Vol. 2 I. 
EXPLANATION OF PLATES.

The drawings were made with the aid of a camera lucida. The lenses employed were a $1.5 \mathrm{~mm}$. Zeiss Apochromatic and a No. 6 Compensating ocular.

\section{Explanation of Plate I.}

FIG. I. Normal fertilization. $25 \mathrm{~min}$. after insemination.

FIG. 2. Egg radiated for $80 \mathrm{~min}$. The development of the sperm is abnormal.

FIG. 3. Egg radiated $35 \mathrm{~min}$. Killed $34 \mathrm{~min}$. after insemination.

FIG. 4. “ "

FIG. 5.

FIG. 6. 


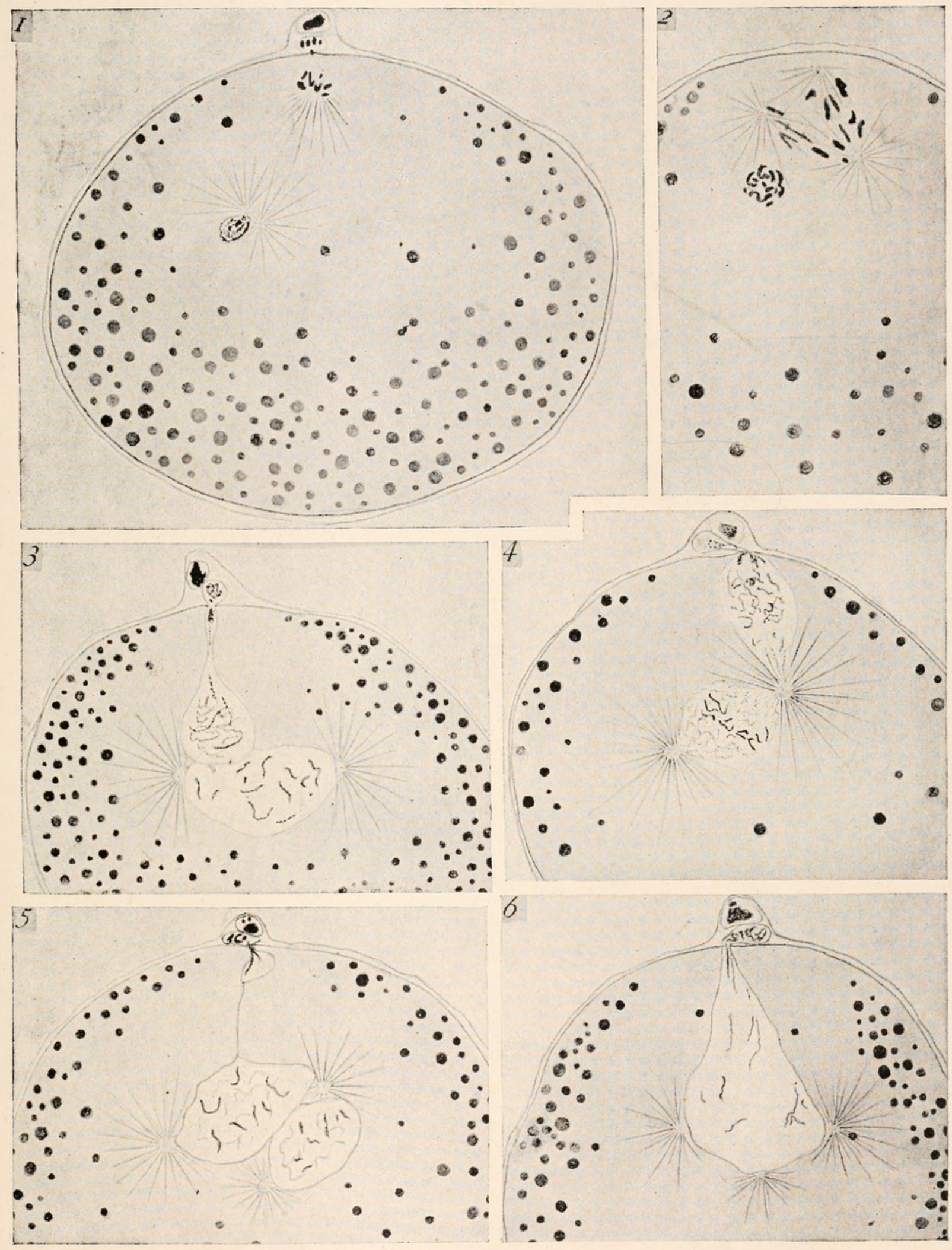

CHARLES PACKARD. 


Explanation of Plate iI.

FIG. 7. Egg radiated $35 \mathrm{~min}$. Killed $34 \mathrm{~min}$. after insemination.

FIG. 8. Egg radiated $25 \mathrm{~min}$. “ $42 \mathrm{~min}$.

FIG. 9. Egg radiated $35 \mathrm{~min}$. “ $39 \mathrm{~min}$.

FIG. Iо. “ “

FIG. II. " 

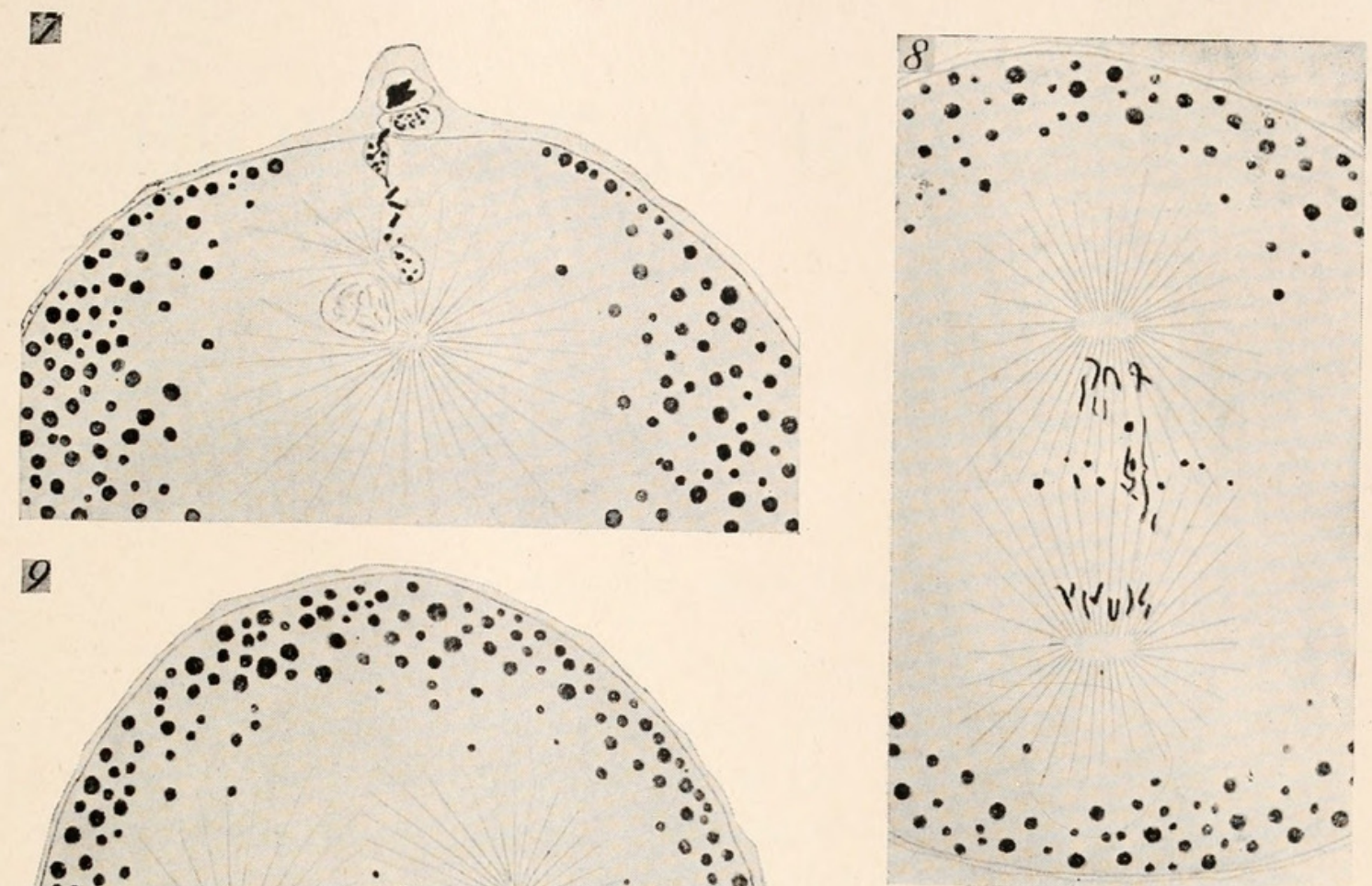

9

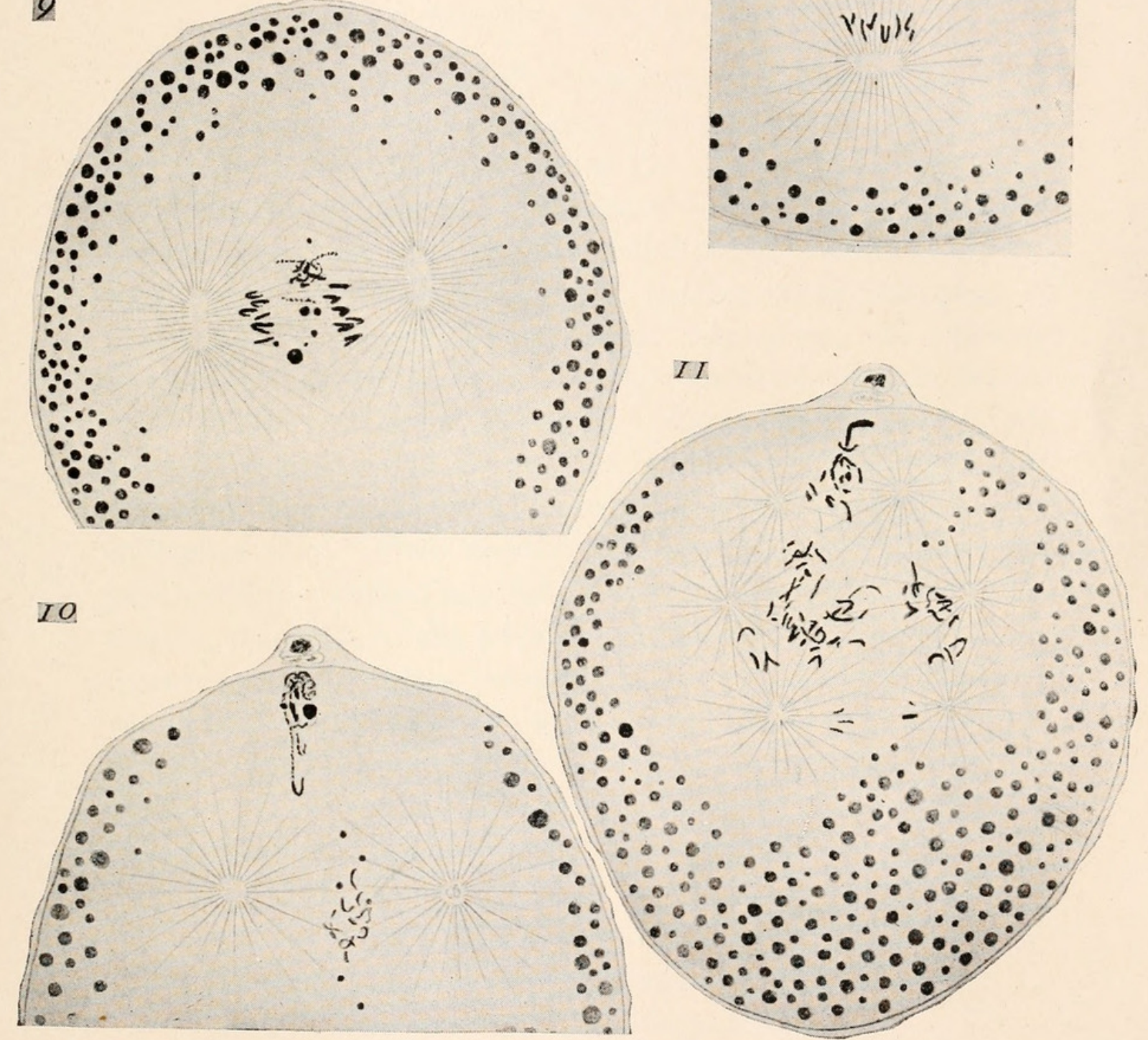

CHARLES PACKARD. 



\section{BIOLOGICAL BULLETIN}

\section{THE CYTOLOGY OF THE MYXOMYCETES WITH SPECIAL REFERENCE TO MITOCHONDRIA.'}

N. H. COWDRY,

Anatomical Laboratory, Johns Hopkins University.

The Myxomycetes, or Slime moulds, constitute a most interesting group of organisms since they are at once so primitive and so specialized and partake of the distinctive properties of both animals and plants. They stand as a sort of link between the two kingdoms. In the plasmodial phase of their existence, for example, they look like gigantic amœbæ, crawl from place to place, exhibit typical protoplasmic streaming and actively phagocytize foreign particles. In the reproductive phase, on the other hand, they form brilliantly colored fungous-like masses strongly suggestive of plants. It is not surprising, therefore, that they have attracted so much interest among botanists and zoölogists alike. Their general form and nuclear structure has been carefully worked up, but no attempt has been made to extend to them the recent work on mitochondria. This is all the more surprising, because the unique properties of these organisms would lead one to suppose that a careful study of mitochondria in them might yield valuable information bearing upon the Myxomycetes themselves, as well as upon the vexed problem of the general functional significance of mitochondria.

\section{Material and Methods.}

The following species of Myxomycetes have been studied:

Arcyria denudata, Badhamia

${ }^{1}$ Contributions from the Anatomical Laboratory, Peking Union Medical College, No. 2 . 


\section{Ceratiomyxa - , \\ Cribraria - \\ Enteridium rozeanum, \\ Hemitrichia clavata, Lycogala epidendrum, Stemonitis}

They were collected during June, July and August near South Harpswell, Me., and during September, October and November in the vicinity of Baltimore, Md. At South Harpswell, the Director, Dr. Kingsley, very kindly placed the resources of the biological laboratory at my disposal and I wish to thank him for his courtesy.

Portions of the plasmodia were collected, shortly before sporangium formation, on the surfaces of leaves, mosses and damp logs. Immature sporangia were found showing well all the stages between the undifferentiated plasmodium and the young spores. These were placed immediately in the fixative. Smears of the plasmodium were treated in the same manner with results which were only confirmatory, but by no means so distinct or satisfactory.

\section{Fixation:}

I. Pieces not larger than 4 cubic millimeters were placed in the following mixture:

Commercial formalin 5 c.c.

(A mixture of formaldehyde, water and methyl alcohol should not be used.)

3 per cent. potassium bichromate.......20 c.c. 4 to 5 days, changing daily.

2. 3 per cent. potassium bichromate, changing every second day, 7 to 8 days.

3. Wash in running water 24 hours.

This is the ordinary Regaud ('Io, p. 296) IVB fixative which can be modified with very excellent results, in some cases, by diluting the fixative with an equal volume of water, applying it for 2 to 4 days only and the bichromate for 3 to 5 days as recommended by Sapehin ('I5, p. 32 I).

Another very good fixative is Regaud IVA:

I. Formalin.................

Water...................... 5 o c.c.

for $\mathrm{I}$ to 5 days.

2. 3 per cent. potassium bichromate, 3 to 4 weeks.

3. Wash in running water, I day. 
I have found that formalin in 5 per cent. or Io per cent. solution preserves the normal form of mitochondria better than higher concentrations. The subsequent long mordanting in potassium bichromate may sometimes be omitted with equally satisfactory results.

Other mitochondrial fixatives have been devised containing chromic, picric or osmic acid in varying concentrations. These are the Benda, Champy and Regaud II and III which give very good results, but mitochondria are, I believe, more constant in their response to the Regaud mixtures given above.

Sections should be cut about 3 or $4 \mu$ in thickness.

\section{Staining:}

The Heidenhain Iron Hematoxylin Method:

I. 5 per cent. iron alum, 24 hours.

2. Wash in water, 5 minutes or less.

3. I per cent. hematoxylin, 24 hours.

(Made by dissolving Io gm. hematoxylin in Ioo c.c. of absolute alcohol. This should be kept until ripe, when io c.c. of the mixture should be added to 90 c.c. of distilled water.)

4. Wash in water, 5 minutes.

5. Differentiate in 2 per cent. iron alum under the microscope.

6. Wash in water at least I hour.

7. Pass through 50 per cent., 70 per cent. and 90 per cent. to absolute alcohol, clear in xylol and mount in balsam.

The Bensley Method (E. V. Cowdry, 'I6b, p.30):

I. I per cent. potassium permanganate, 30 seconds.

2. 5 per cent. oxalic acid, 30 seconds.

3. Rinse in water.

4. Stain in Altmann's anilin fuchsin (anilin water Ioo c.c., acid fuchsin $20 \mathrm{gm}$.), heat once until vapor arises, 6 minutes.

5. Rinse quickly in distilled water.

6. Differentiate in I per cent. aqueous solution of methyl green or toluidin blue very quickly. 
7. Drain and dehydrate quickly with absolute alcohol.

8. Clear in xylol and mount in balsam.

The Altmann Method:

I. Stain on slide with Altmann's anilin fuchsin, heating once until vapor arises, 6 minutes.

2. Wash quickly in water.

3. Differentiate in alcoholic solution of picric acid (made by mixing one part of a saturated alcoholic solution with two parts of distilled water) until the sections assume a yellowish-pink color.

4. Dehydrate very quickly in absolute alcohol, clear in xylol and mount in balsam.

The Benda Method ('OI, p. I55):

I. 4 per cent. iron alum, 24 hours.

2. Wash in water, 2 or 3 minutes.

3. Sulphalizarinate of soda, 24 hours. (Made by adding a saturated alcoholic solution of sulphalizarinate of soda drop by drop to distilled water until an amber color is obtained.)

4. Dry excess with blotting paper.

5. Cover with a solution of crystal violet, and warm until production of vapor begins, 5 minutes.

(Made by mixing

I vol. saturated solution of crystal violet in 70 per cent. alcohol.

I vol. acid alcohol.

2 vol. anilin water.)

6. Dry off excess with blotting paper.

7. Differentiate with 30 per cent. acetic about 3 minutes.

8. Dehydrate in absolute alcohol quickly.

9. Pass through xylol to balsam.

\section{OBSERVATIONS.}

The chief stages in the complicated life history may first be mentioned.

The vegetative phases or plasmodia are found in damp locations, on the surface of logs, fallen leaves and debris. They are 
slippery, slimy masses, sometimes nearly a foot in diameter. The color is often very brilliant. For instance, in Ceratiomyxa it is white, Fuligo septica yellow, Lycogala epidendrum light red and Hemitrichia vesparium a beautiful dark crimson. But the color is of no generic significance because different species of the same genus exhibit great variability. It is to be noted that they never, under any circumstances, contain chlorophyll, and in this respect they differ sharply from all plants which are not saprophytic and closely approximate to animals. Plasmodia are naked masses of protoplasm containing abundant nuclei, but destitute of cell walls, thus resembling in many ways the syncytia of higher animals and large multinucleate giant cells. They apparently possess all the properties of amœbæ, especially the power of amœboid movement and of being actively phagocytic. They engulf bacteria and foreign particles in much the same way as the so-called macrophages which have been brought into prominence lately in mammals through the use of vital dyes.

In some cases, when the conditions become unfavorable, the nuclei tend to clump together into larger or smaller masses which encapsulate and desiccate. This resting stage, called the sclerotium, may persist for some time. On the resumption of favorable conditions the envelopes are dissolved and the plasmodia reformed.

The reproductive stages are just as remarkable. The plasmodium first migrates to the upper surface of the log or stump or other object, as the case may be, where it will be exposed to more light. It then undergoes great and varied changes in different species. It may form a cushion-like mass, an æthalium, as in Fuligo; a flat vermicular aggregation called a plasmodiocarp; or a number of separate sporangia as in Hemitrichia clavata. The sporangia may be either sessile or elevated on pedicels. They are surrounded by a definite envelope, termed the sporangium wall, which may even be double. The sporangia contain spores of many hues and varied sculpture and in most cases a capillitium. The capillitium, which is composed of tubes or of threads, generally arranged in the form of a network, is sometimes supportive and may be, at the same time, concerned with the dispersal of the spores. The sporangium wall, the spore wall and the capillitium are all differentiations of the plasmodium. 
On germination the protoplasmic content of the spore escapes. It soon becomes actively motile, develops a flagellum and food vacuole and reminds one forcibly of the flagellates. The flagellum is withdrawn and the organism either goes into a brief resting stage (microcyst) or multiplies freely by fission. In the case of multiplication by fission there is a karyokinetic figure and distinctive chromosomes may be seen. Finally these swarm cells clump together and fuse to form another plasmodium.

The granulations about to be described are identified as mitochondria on the basis of the following observations:

I. Their morphology is identical with that of mitochondria in the higher forms of both plants and animals. While they are for the most part spherical, rod-shaped forms do occur.

2. Their distribution is also characteristic. They are generally single but are often arranged in rows like streptococci, or in clumps. They seem to be rather more abundant near the nuclei and about the circumference of the vacuoles.

3. The janus-green reaction is exhibited beautifully by the mitochondria when the contents of the adult spores are crushed out in janus-green solution.

4. They are easily fixed by Regaud's mixtures, as indicated above.

5. They may be stained by the standard mitochondrial methods including the iron-hematoxylin method, the Altmann method, fuchsin and methyl green, and the Benda method.

I have been able to discover no descriptions relating to them in the literature except possibly that of Harper ('oo, p. 25I, fig. I8), who made a study of cell and nuclear division in Fuligo varians, and found certain granules, in a single spore cell only, which he refers to as "granules of reserve material," in a preparation fixed in Flemming's weak fluid and stained with safranin, gentian violet and orange. These granulations present the same morphology as mitochondria, but in the total absence of detailed information, there is no means of ascertaining their nature.

In Enteridium rozeanum, we find comparatively large areas of protoplasm in which no differentiations of any sort can be distinguished. There are no nuclei, no mitochondria and but few vacuoles (Fig. I). Such extensive areas of protoplasm without 
visible organization, are, I believe, without counterpart in any other living organisms, outside the Myxomycetes. We must not commit the usual error, however, of calling this protoplasm homogeneous, because homogeneous protoplasm would be incapable of any vital manifestations or of activity of any sort. They stain light gray with iron hematoxylin, green with fuchsin methyl green, yellow with the Altmann method, and a dull pink by the Benda method. Around their margins groups of nuclei with a few mitochondria may be seen and a greater tendency toward vacuolation is noted.

In other parts of the plasmodium the mitochondria are fairly abundant (Fig. 5). They are for the most part spherical and of quite uniform size, varying between 0.25 and $0.5 \mu$ in diameter. The absence of the really tiny mitochondria, to be seen occasionally in higher forms, should be noted. Since the mitochondria never exceed these limits, the possibility of plast formation may be definitely excluded, except perhaps along the margins of the capillitial vacuoles. Rod-like mitochondria occur but they are quite rare. Filamentous, net-like and ring forms were never seen. The spherical mitochondria often clump together in pairs like diplococci or in linear series like streptococci. There can be no confusion with bacteria, however, because of their perfectly definite and characteristic reactions to fixatives and stains, which have already been mentioned. They are likewise spherical and look quite homogeneous. They stain quite darkly with iron hematoxylin and undergo definite modifications with the approach of spore formation, to be described subsequently. The ground substance is but faintly vacuolated and the nuclei are scattered irregularly, but fairly evenly.

Sometimes the vacuolation of the ground substance is much more marked, as is illustrated in Fig. 3. The vacuoles themselves are quite large and are usually, though not always, spherical. They often seem to run together. They contain for the most part a colorless liquid, never distinct spherules of protein as in the so-called "vacuoles de ségrégation" of Renaut and Dubreuil. Their walls are merely separation membranes and cannot be distinguished except in Cribraria where well formed and quite thick boundaries occur. 
The mitochondria, which are also quite numerous, are frequently clumped about the periphery of the vacuoles, but they are never to be found within them, and this is another and very important distinction between mitochondria and bacteria which are phagocytized by Myxomycetes and are segregated and digested inside the vacuoles. The heaping up of mitochondria about the vacuoles may be merely a surface tension phenomenon. Their accumulation about the nuclei represented in Figs. I, 3 and 4 may also be due in part to surface tension. It is important to bear in mind that the areas of clear protoplasm are, in their deeper parts, devoid of both mitochondria and vacuoles which become more numerous as we approach the nuclei, and that we may be dealing with nothing more than a heaping up of mitochondria in foci of more rapid metabolism.

Still more abundant mitochondria are shown in Figs. 4 and 6 but the vacuoles are fewer. Different parts of the organism are often separated by irregular, dense and homogeneous septæ, not related to capillitium threads, one of which is illustrated. It often happens that stretches of protoplasm separated in this way may exhibit a difference in the intensity of staining, the extent of vacuolation or in the number of mitochondria.

Fig. 2 of Lycogala epidendrum shows a portion of the active protoplasm of the plasmodium migrating upward through the interstices of the hypothallus to the æthalium where the spores will be formed. The nuclei are still spherical and of about the same size, but contain more distinct and prominent nucleoli. The mitochondria show little tendency toward perinuclear condensations. The protoplasm appears to be of rather open texture. The hypothallus presents an ill-defined fibrous appearance and is quite devoid of mitochondria and nuclei.

\section{Spore Formation:}

The early stages in spore formation in Badhamia are illustrated in Fig. 8. The nuclei, which were so conspicuous in the plasmodium, can no longer be seen with the aid of mitochondrial methods of staining. Their loss of affinity for iron hematoxylin and other basic dyes calls to mind the condition of affairs in oögenesis of certain animals where there is a temporary dis- 
appearance of basophilic chromatic material. The ground substance of the protoplasm presents a sort of flocculent appearance, being denser in some regions than in others. The first indication that spore formation is taking place is to be seen in the clumping of the mitochondria. All the mitochondria are in the form of spherules of fairly uniform size. They stain with equal intensity with iron hematoxylin. The differences in shade illustrated are indicative of perspective only. Soon the little clumps of mitochondria become surrounded by a membrane, the first spore membrane, which stains only faintly with iron hematoxylin. Traces of nuclei can be seen in some of these early spores. Spore formation proceeds from a definite center so that it is possible to see many stages in a small area. Fig. 8 is taken through such an area, the early stages being above and the later stages below. In certain other Myxomycetes, however, spore formation is said to take place simultaneously throughout the whole sporangium.

Rather more advanced stages in Fuligo septica are shown in Figs. 7 and 9. Here all the spores are well formed and discrete and surrounded by membranes. The nuclei have reappeared. They are spherical and stain diffusely. It is difficult to distinguish any nucleoli within them, since they are of about the same size as the mitochondria. There is no apparent change in the mitochondria. The ground substance of the protoplasm presents the same flocculent appearance with a marked tendency toward the production of vacuoles in some of the spores.

Very profound changes now take place. In Fuligo septica (Fig. Io) the spores lose every trace of their membranes and degenerate into naked, nucleated masses of protoplasm which are distinctly smaller than in the preceding stage. They also lose their spherical or oval shape and become often quite angular. Their nuclei stain so intensely with iron hematoxylin that it is difficult to make out any structure in them. The ground substance is more homogeneous and stains diffusely and evenly. The appearance of the mitochondria has completely changed. Instead of occurring in the form of large spherules they are now considerably smaller, rod-like and sometimes almost filamentous. They often clump about the nuclei in a manner suggestive of 
certain stages in the spermatogenesis of mammals. But they may be quite uniformly distributed through the cytoplasm or else condensed to one side of the nucleus only. Different spores vary greatly in this respect. Sometimes the spores stain so intensely that the mitochondria can only be distinguished with difficulty. The large clear vacuoles and tortuous spaces which occur in some of the spores indicate that it might be worth while to study this material with methods adapted to the demonstration of the vacuolar apparatus. The conditions in Badhamia are identical except for the fact that the mitochondria in the spores are much more numerous and filamentous.

Other alterations accompany the formation of the definitive spore capsules which are best seen in sections of Enteridium rozeanum (Fig. II). The capsules are quite complicated in structure. At first sight they seem to be covered with spines but Fig. I I shows that the spines are in reality the walls of little compartments set upon a homogeneous basement membrane. It often happens that the substance of the spore shrinks away from the membrane. Sometimes this is followed by the partial collapse of the membrane itself. The contents of these mature spores are important. The nuclei seem to be much broken down and traces of them can be distinguished only after careful study. The mitochondria have, almost uniformly, reverted to their original spherical shape and can easily be stained in the usual way with janus green, if the spore contents are squeezed out in a solution of $\mathrm{I}$ : IO, OOO of the dye.

The entire process of spore formation is subject to great variation in different Myxomycetes. In Arcyria denudata, for instance, the process is quite different from that which I have described in Badhamia, Fuligo and Enteridium. The first sign of approaching spore formation is a segregation and encapsulation of comparatively large masses with abundant nuclei and many mitochondria. Instead of being hard to distinguish, the nuclei are quite conspicuous with well-defined chromatin networks and nucleoli. Through successive divisions these multinucleated masses become smaller and smaller. As the final division approaches, the walls become thicker and the nuclei stain less intensely, as is shown in Fig. I2. Division is by mitosis. The 
structure of the spores is very intricate and is best brought out when stained with fuchsin and methyl green. The nuclei are large and faintly stained and usually present a solitary spherical nucleolus which likewise stains but faintly. There is often, though not always, present in the cytoplasm an irregular mass of material surrounded by a vacuole. The material can be clearly resolved into acidophilic and basophilic constituents, staining with fuchsin and methyl green respectively. Of the two, the basophilic structures are the most definite and appear in the form of definite spherules suggestive in some measure of chromosomes. But the occurrence of the material in vacuoles is equally suggestive of phagocytosis, which, however, would seem to be unlikely in view of the dense membrane surrounding each spore. Only further study will reveal the nature of the material. Mitochondria are distributed quite evenly throughout the remainder of the cytoplasm and are characterized by their rod-like shape. There is no counterpart here for the changes in the morphology of mitochondria observed in Badhamia, Fuligo and Enteridium.

No special provision is made during spore formation, or in cell division generally, for an equal division of mitochondria, which might be looked for if we regard them as in any sense carriers of heredity. They do not, like the nucleus, change their solubilities or staining reactions during spore formation. This is the more interesting since the resistance of the mitochondria increases progressively in the spermatogenesis of mammals. There is some indication, however, that with spore formation there is a tendency toward a reduction in the amount of mitochondria with relation to the cytoplasm.

\section{Capillitium:}

I have not traced the formation of the capillitium from confluent vacuoles as described by Strasburger but my observations of the later stages are of interest in connection with the work of Harper and Dodge ('I4, p. 3). In plasmodia of Hemitrichia clavata and rubiformis fixed in weak Flemming and stained with either safranin, gentian violet and orange $\mathrm{G}$, or with iron hematoxylin, they describe lines running toward the vacuolar tube, where their centers of convergence are marked by a series of granulations (see their Figs. I-5). 
In my own material of the same species, I have been unable to find the radiating lines and perhaps this may be due to the fixative which I have used, but I have observed the granules. The granules in my preparations fixed in Regaud's fluid and stained with iron hematoxylin are almost indistinguishable from the mitochondria which I see in the surrounding plasmodium (Fig. I3). They are of the same shape except in some cases where they are in very intimate contact with the vacuolar membrane and flatten out upon it, which may be due to surface tension. It is important to note that the mitochondria are not illustrated in Harper and Dodge's figures which would lead one to suppose that they have been destroyed by the fixative; so that our conclusion is warranted that the granules which surround the vacuole and constitute the termini of the lines are more resistant than the mitochondria to fixation. It is probable that the destruction of the mitochondria may have been occasioned by the acetic acid in the Flemming's fluid. We know that plasts generally are more resistant to acetic acid than are true mitochondria, which would lead us to suppose that the granules in question are plastlike. This interpretation falls well in line with Harper and Dodge's explanation of the significance of the radiating lines. They regard them as "pathways by which materials are brought in from the surrounding cytoplasm." I cannot agree with them, however, in their interpretation of the significance of the nuclei as morphogenic factors. I would be inclined, on the contrary, to regard the granules as plast-like and perhaps truly formative, as in the higher plants.

Furthermore, Harper and Dodge ('I4, p. 7) have described certain interesting formations within the lumen of the capillitial tube. They say that:

"The granular material in the interior of the capillitial thread (Figs. I and 2) becomes less as the wall thickens and the spirals appear, and as the thread matures it practically disappears (Figs. 3 and 4). There is, of course, no evidence that granular material as such passes from the interior of the thread into the forming spirals. We are inclined to suspect that the stainable granules in the interior of the thread are precipitation products formed in fixation, and that in the living condition the capillitial 
cavity contains only materials in solution in the cell-sap. These materials may be used up in the formation of the capillitial wall and spirals so that in late stages no such precipitation products are formed."

In the first place my observations show, contrary to Harper and Dodge, that the granular material is quite abundant in well formed capillitial threads. In Fig. I7 of Arcyria denudata the granules are very numerous and occupy almost the whole interior of the thread. In fact I have never found them to be so abundant in early stages in the formation of the capillitial threads in Hemitrichia clavata. Neither have I found any indication that granular material as such passes from the interior of the thread into the forming spirals (see Figs. I3, I5, I7, I8 and I9). It is hard for me to believe that these granules are precipitation products formed by fixation. It will be noted that they are often of astonishingly uniform size and shape which one would not expect in products of precipitation or coagulation. Moreover they are often absent or isolated or distributed evenly over the interior of the thread showing little tendency to clump, which one would likewise expect in the case of products of fixation. They do resemble mitochondria very closely. Their rod-like and even filamentous shape is well illustrated in my figures. They are of ten arranged in rows, suggestive also of mitochondria. They are usually about the same size as mitochondria but they are sometimes larger, as shown especially in Fig. I7. Their staining reactions also are suggestive of mitochondria, for they take the fuchsin as well as the iron hematoxylin, after fixation in Regaud's fluid. Nevertheless we cannot consider them to be mitochondria because they occur within the capillitial tubes, quite apart from nuclei and from protoplasm. It would appear more probable that they constitute merely a part of the material brought in, which is useless in the formation of the capillitial wall.

Harper and Dodge refer to two types of nuclei at this stage in Hemitrichia clavata and I have been able to confirm their finding as illustrated in Fig. I9. It will be seen that the majority of the nuclei are large and pale and have definite nucleoli. Some, however, are smaller and much more intensely stained with the hematoxylin: these Harper and Dodge regard as undergoing 
degeneration. They are distributed quite evenly throughout the plasmodium which definitely precludes the possibility that they may result from mechanical injury. In preparations stained with fuchsin and methyl green, the small nuclei take the fuchsin to a remarkable degree, behaving just like the nuclei of the spores, which stain in precisely the same way. This points, perhaps, to the conclusion that these small nuclei are undergoing differentiation with a view to spore formation.

\section{Sporangium Wall and Hypothallus:}

My observations do not bear upon the question of the mode of formation of the sporangium wall and hypothallus. In all probability both of them are differentiations or secretions of the plasmodium as is generally supposed. I have found no indications that the mitochondria play any part in their formation. They are at first gelatinous and afterwards become membranous. A good account of sporangium formation in Trichia and Arcyria is given by Kranzlin ('o7, p. I79).

With this progressive differentiation of spores, capillitium, sporangium wall and hypothallus, there is a distinct and gradual alteration in the plasmodium itself. At first it usually contains comparatively large quantities of debris, the more solid portion of which is left behind in its path and persists to some extent in the hypothallus. There is a further segregation with the formation of differentiated products, the end result being that the protoplasm of the spores is comparatively free of foreign material.

\section{Discussion.}

We are inclined to divide living organisms into two groups, plants and animals, and perhaps unconsciously to assume that this classification is sufficient. It is interesting to find that the Myxomycetes, or slime moulds, cannot be dismissed so easily, for they partake of the properties which we have been inclined to regard as distinctive of plants, on the one hand, and of animals, on the other. Great difference of opinion is manifest in the literature. At first they were considered to be plants and were called Myxogastres, in I 829, by Fries, who grouped them among the fungi. The word Myxomycetes also indicates their fungous- 
like properties. With the discovery of the plasmodium, opinion changed and the term Mycetozoa was introduced. Even now there is absolutely no concensus of opinion on the subject of their relationships. Coulter, Barnes and Cowles ('Io, p. I) place them tentatively among the first of the Thallophytes. Chamberlain ('I5, p. I52) groups them with the Schizophytes. Torrend ${ }^{1}$ and Schintz $z^{2}$ conclude that the Myxomycetes are related to Fungi rather than to animals. And finally Osborn ('i I, p. 339) Schwartz ('I4, p. 238), Harper ('oo, p. 235) and others associate them with the Plasmodiophoraceæ, Chytrideæ and Acrasieæ; while Maire and Tison ${ }^{3}$ relate them to the Sporozoa, Elliott ${ }^{4}$ to animals generally, by reason of their feeding reactions, and Parker and Haswell ('97, p. 6I) classify them as intermediate between the Rhizopoda and the Mastigophora.

We may summarize their plant-like features as follows: In the first place they form brilliantly colored fungous-like masses strongly suggestive of true fungi. The capillitial threads which are found in the sporangia frequently play an important part in the dispersal of the spores and remind one of the elaters of liverworts. If Harper and Dodge ('I4, p. 9) are correct, however, there would appear to be a closer analogy between the capillitium and the protozoan endoskeleton, since they believe them both to be formed by a process of intraprotoplasmic secretion. They bear also a certain superficial resemblance to the puff-balls, which have likewise a mass of spores supported by a capillitium-like framework and contained in a sporangium. Pinoy ('o8, p. 630) records a sexual dimorphism in Didymium which reminds him of the condition in Mucor as described by Blakeslee. Moreover the supposed presence of cellulose in the sporangium walls, the spore walls and the cyst walls of the sclerotium indicate a plant affinity. And finally the possession of well-defined spores is cited as evidence that they should be regarded as plants.

Yet they apparently resemble animals just as closely and for this reason they have been called "Mycetozoa" (fungus-animals),

${ }^{1}$ Reviewed in Jour. Roy. Micr. Soc., I9Io, p. 221.

2 Jour. Roy. Micr. Soc., I914, p. 292.

3 Jour. Roy. Micr. Soc., I909, p. 626.

${ }_{4}$ Jour. Roy. Micr. Soc., I9I 7, p. 500. 
a term which indicates a compromise, and is perhaps preferable. We may enumerate briefly their many points of resemblance to members of the animal kingdom. It has already been mentioned that the plasmodium behaves to all intents and purposes like a gigantic amœba. It moves freely from place to place, burrows deeply in rotten wood and into the substrata when it is necessary to obtain nutriment, and, most significant of all, it is capable of phagocytosis. That is to say, it can actively devour and digest bacteria and other foreign bodies which it is able to engulf. In the total absence of chlorophyll, the green pigment so characteristic of plants generally, and the accompanying saprophytic behavior, they resemble the fungi, bacteria and other saprophytic plants, on the one hand; and the whole animal kingdom on the other, with but few exceptions. Following a study of the feeding habits of Badhamia Elliott ${ }^{5}$ looks on Mycetozoa as parasites, more animal than vegetable. The swarm cells with their flagella and food vacuoles, their motility and power to multiply by fission call to mind the Flagellata.

To these points of similarity to animals may now be added the mitochondria, which I have found to occur in all the species of Myxomycetes which I have examined, numbering ten or more. The mitochondria observed are identical, so far as can be ascertained, with the mitochondria in the higher plants and in the whole animal series from the protozoa to man. The point is, that in some lower plants, the mitochondria are apparently totally absent or else quite different from those which I have described in the Myxomycetes. They have not been described in the Cyanophyceæ; in the bacteria their presence is doubtful (E. V. Cowdry 'I6a, p. 433), and in the Chlorophyceæ they have been found in but few forms: Guilliermond ('I3, p. 86) thinks that here the enlarged chloroplast takes over their function. So that the mitochondria of the Myxomycetes approximate far more closely to the mitochondria of animals than to those of the lowest plants.

The discovery of mitochondria in the Myxomycetes extends our knowledge of the extraordinary breadth of distribution of these granulations in living matter. I have already shown ('I 7, p. 225) that, so far as our present methods of technique go; 
they are identical in animals and in plants. Champy's ('i I, p. I54) statement that "I would not regard as living a cytoplasm which does not contain mitochondria" is rather radical in view of our knowledge of the structure of the lowest plants. The bacteria and the Cyanophyceæ are of special interest in this connection. Furthermore, it is common to find comparatively large stretches of protoplasm in certain of the Myxomycetes which contain no mitochondria. While we cannot say how active this protoplasm is we cannot regard it as totally inert and lifeless.

Concerning the continuity of mitochondria in the Myxomycetes it may be said that they invariably occur in the plasmodia as well as in all stages of spore formation, even to the adult spore. While I have not yet studied the swarm spores, it is extremely probable that mitochondria occur in all stages of the life cycle. No indications were observed of de novo formation of mitochondria though it is highly improbable that if such occurred they would have been detected. It seems unnecessary to assume, as some workers have done, that we must find mitochondria grading into the invisible in order to demonstrate a de novo origin, because it is possible that the mitochondrial aggregate must attain to a certain size before acquiring characteristic density and staining reactions.

The cyclical changes in the morphology of the mitochondria suggest similar changes which have already been described, long since, in higher forms. The most striking of these is the change from the large spherical mitochondria of the youngest spores to the smaller rather rod-like ones of those which are more mature. They resume their granular condition in the mature spores. They are often rod-like and arranged parallel to the direction of the current in streaming protoplasm of active plasmodia. Their clumping about the nucleus and their whole behavior make it very plain that their morphology and distribution are governed by the same laws here which operate in animals and in the higher plants, whatsoever they may be.

It is interesting to note, a propos of current statements to the effect that the mitochondria are transformed into cellular differentiations, that, so far as can be ascertained, they play no 
active part in the formation of the sporangium wall, the complicated spore capsules and capillitia, the hypothallus, the pigment and lime deposits of the Myxomycetes.

The occurrence of typical mitochondria in the active plasmodia, crawling from place to place, as well as in all stages in spore formation even to the fully mature spore, surrounded as it is with a thick restraining horny capsule must indicate one of two things: either that the mitochondria are active in some of these locations and passive in others or else that they take part in the activities of the cell in all stages. The second supposition is usually granted by workers on mitochondria in higher forms. It is apparent, then, that this study of the Myxomycetes materially supports the general supposition that the mitochondria are concerned in some fundamental vital process common to all living matter, perhaps with protoplasmic respiration and possibly with growth.

\section{Conclusions.}

I. Mitochondria occur in Arcyria, Badhamia, Ceratiomyxa, Cribraria, Enteridium, Fuligo, Hemitrichia, Lycogala, Stemonitis and probably in all other Myxomycetes.

2. The mitochondria in Myxomycetes so far as can be ascertained differ in no wise from those occurring in the majority of plants and in all animals.

3. The Myxomycetes resemble the lower animals much more closely than they do the lower plants with respect to their mitochondrial content.

4. The Myxomycetes offer a unique opportunity in many ways for the experimental study of mitochondria.

Benda, C.

BIBLIOGRAPHY.

'or Die Mitochondriafärbung und andere Methoden zur Untersuchung der Zellsubstanzen. Verh. d. Anat. Gesell., pp. I55-I 74.

Chamberlain, C. J.

'I5 Methods in plant histology. Univ. of Chicago Press, 3 I 4 pp.

Champy, C.

'I I Recherches sur l'absorption intestinale et le rôle des mitochondries dans l'absorption et la sécrétion. Arch. d'Anat. micr., T. I3, pp. 55-I 70.

Coulter, J. W., C. R. Barnes and H. C. Cowles.

'Io A Textbook of Botany. Vol. I, Morphology and Physiology. American Book Co., New York, 484 pp. 


\section{Cowdry, E. V.}

'I6a The general functional significance of mitochondria. Amer. Jour. Anat., Vol. I9, pp. 423-446.

'I6b The structure of chromophile cells of the nervous system. Contributions to Embryology, No. II, pp 27-43.

\section{Cowdry, N. H.}

'I7 A comparison of mitochondria in plant and animal cells. Biol. Bull., Vol. 33, pp. 196-228.

\section{Guilliermond, A.}

'I3 Sur la signification du chromatophore des algues. C. rend. Soc. Biol., T. 75 pp. $85-87$.

\section{Harper, R. A.}

'oo Cell and nuclear division in Fuligo varians. Bot. Gaz., Vol. 30, pp. 2 I 7-25I.

Harper, R. A., and B. O. Dodge.

'I4 The formation of the capillitium in certain Myxomycetes. Ann. Bot., Vol. 28, pp. I-I8.

\section{Kranzlin, Helene.}

'o7 Zur Entwicklungsgeschichte der Sporangien bei den Trichien und Arcyria. Arch. f. Protisten., Bd. 9, pp. I70-I94.

\section{Osborn, T. G.}

'II Spongospora subterranea. Ann. Bot., Vol. 25, pp. 327-34I.

Parker, T. J., and W. A. Haswell.

'97 Textbook of Zoology, Vol. I, London, Macmillan and Co., 779 pp.

Pinoy, E.

'o8 Sur l'existence d'un dimorphisme sexuel chez un myxomycete, didymium Regaud, Cl. nigripes, Fries. C. rend. Soc. Biol., T. 74, pp. 630-631.

'ıo Étude sur la structure des tubes seminiféres, etc. Arch. d'Anat. micr., T. II, pp. 29I-433.

Sapehin, A. A.

'I5 Untersuchungen über die Individualität der Plastide. Arch. Zellforsch. Bd. I3, pp. 319-398.

Schwartz, E. J.

'I4 The Plasmodiophoraceæ and their relationship to the Mycetozoa and the Chytridiæ. Ann. Bot., Vol. 28, pp. 227-240. 


\section{Explanation of Plate I.}

All the figures have been drawn with Zeiss apochromatic $1.5 \mathrm{~mm}$., compensating ocular 8 and camera lucida. They have been reproduced without reduction so that the magnification as they now appear on the plates is 2,600 diameters.

FIG. I. Enteridium rozeanum fixed in Regaud's fluid and stained by the Benda method. The mitochondria are stained a dark purplish-blue color against a pink background. Plasmodium showing a large area of apparently homogeneous protoplasm, a few spherical nuclei and some mitochondria, are seen to one side. The ground substance shows a tendency to be more vacuolated and to stain fainter in the vicinity of the nuclei.

FIG. 2. Lycogala epidendrum fixed in Regaud's fluid and stained with iron hematoxylin. The mitochondria are stained bluish-black against a gray back ground. A portion of the plasmodium crawling upward toward the æthalium on the meshwork of the hypothallus.

FIG. 3. Enteridium rozeanum same fixation and stain as Fig. I. Likewise a portion of the plasmodium greatly vacuolated. The nuclei are stained intensely and the mitochondria are often grouped about them as well as about the vacuoles.

FIG. 4. The same showing quite well differentiated fibrous structures which often appear to be of the nature of septæ separating the plasmodium into different areas.

Fig. 5. Another part of the same plasmodium, with scattered nuclei and mitochondria of various forms. The ground substance shows an indistinct vacuolation. 


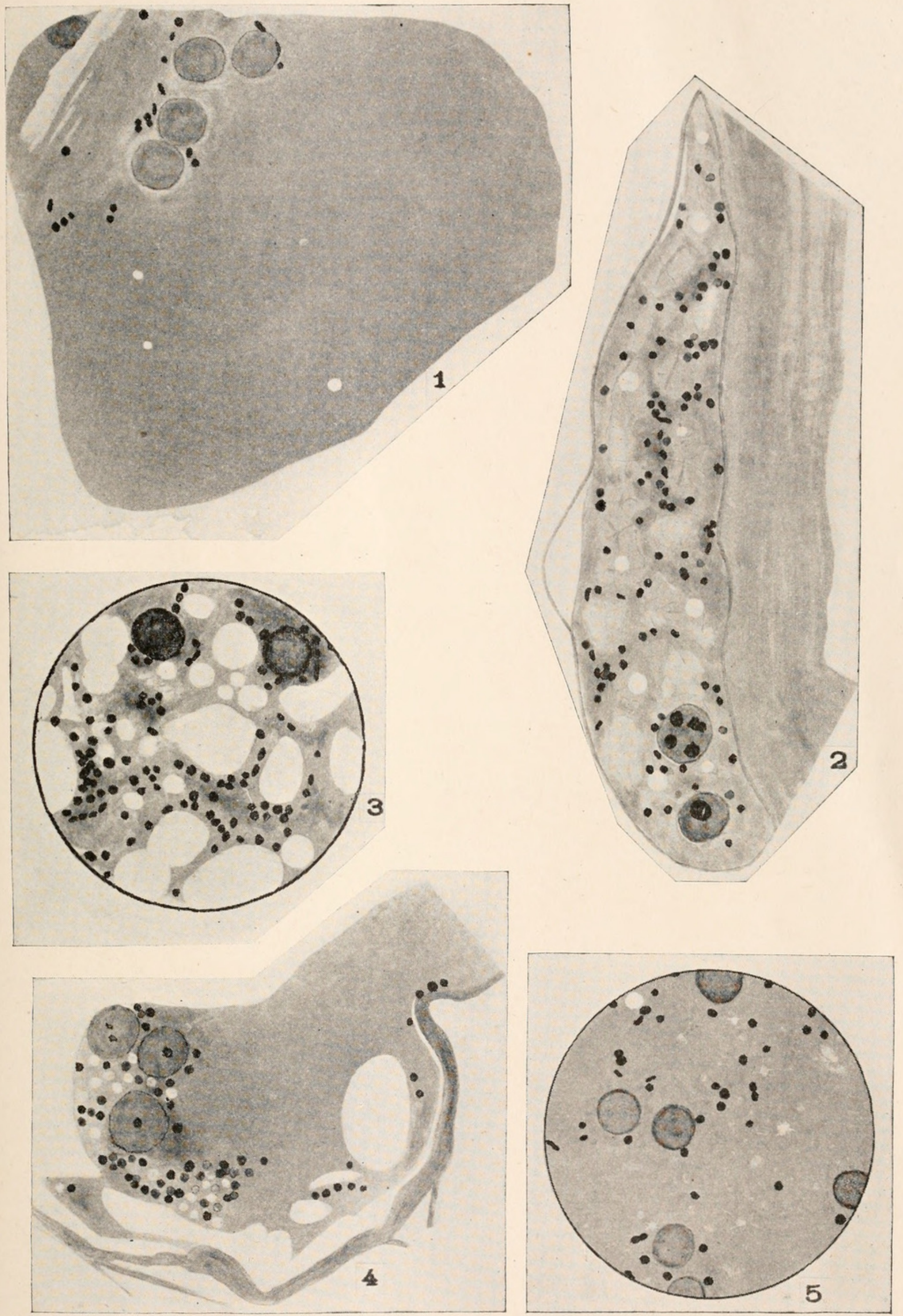

N. H. COWDRY. 




\section{Explanation of Plate iI.}

FIG. 6. Enteridium rozeanum fixed in Regaud's fluid and stained by the Benda method, mitochondria blue-black and ground substance pink. Another septum is shown at the side. The mitochondria occur in distinct clumps sometimes about the nuclei. The apparent differences in the staining reactions of the mitochondria simply indicate depth in the preparation.

FIG. 7. Fuligo septica fixed in Regaud's fluid and stained with iron hematoxylin, mitochondria blue-black and ground substance gray. Immature spore with a faint nucleus and conspicuous mitochondria.

FIG. 8. Badhamia - fixed and stained in the same way. It shows the first stages in spore formation. The nuclei are indistinct; the mitochondria show progressive clumping and the spore membranes are gradually formed.

FIG. 9. Fuligo septica, same fixation and stain. More mature spores of smaller size, without a distinct cell membrane, with strongly stained nuclei and more rodlike mitochondria. The mitochondria often closely approximate to the nucleus. The ground substance is more homogeneous than in the preceding stage and more deeply stained.

FIG. I0. Fuligo septica fixed and stained in the same way showing rather later stages in spore formation than Figs. 7 and 8. The spores are surrounded with a definite membrane. They have faintly staining nuclei and spherical mitochondria. One of them is rather more advanced.

FIG. II. Enteridium rozeanum same fixation and stain. Quite advanced spores with definite capsules. The nuclei are faintly stained and the mitochondria spherical and in one case clumped near the nucleus.

FIG. I2. Arcyria denudata fixed in Regaud's fluid and stained with fuchsin and methyl green. The mitochondria are crimson against a greenish background. One cell not finally divided containing three nuclei and two others each containing a mass of material in a vacuole. The material consists of a basophilic part, staining green, definitely delimited in the form of spherules, and of a more irregular acidophilic mass staining red. 

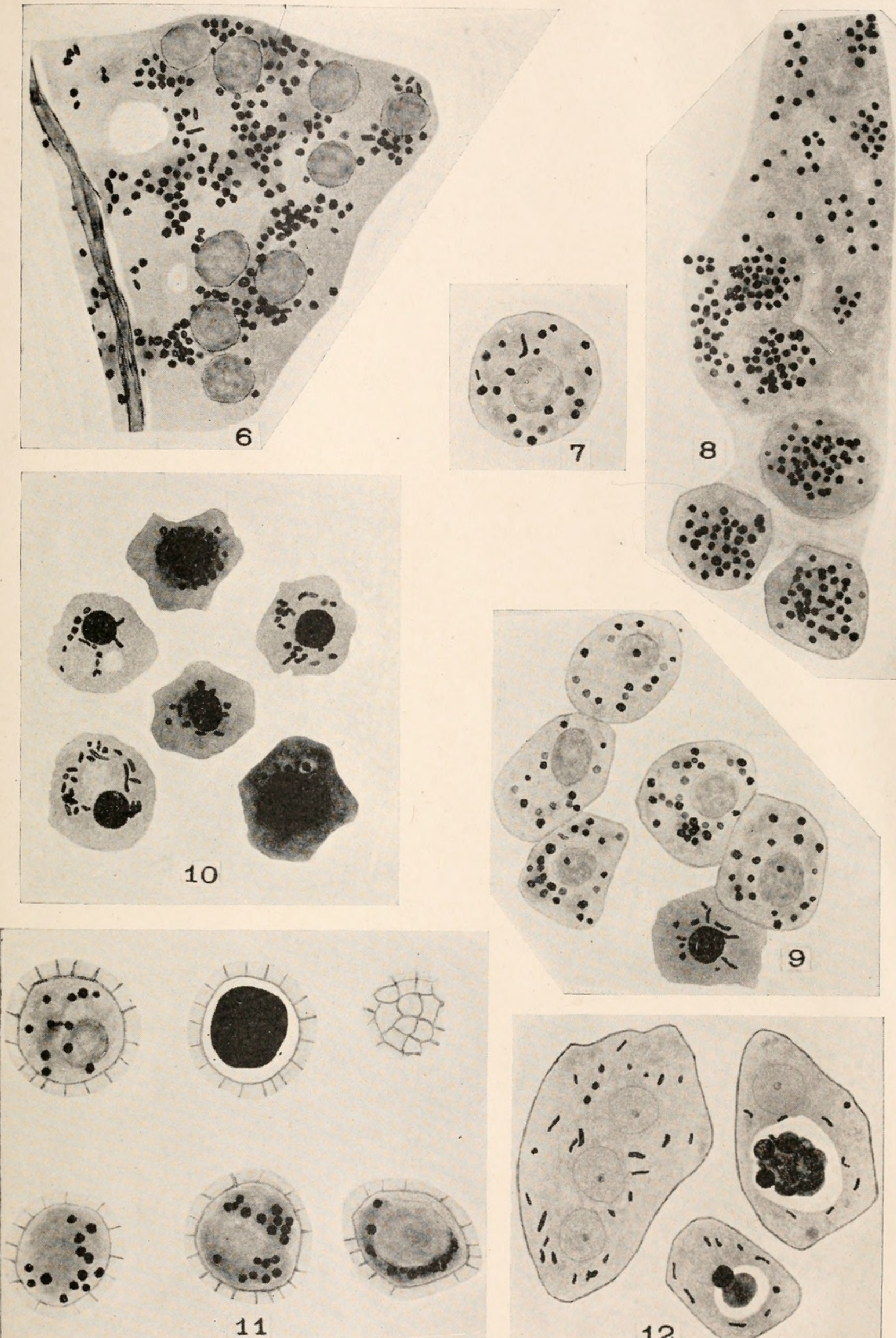




\section{Explanation of Plate iII.}

FIG. I3. Hemitrichia clavata fixed in Regaud's fluid and stained with iron hematoxylin. The mitochondria are blue-black and can with difficulty be distinguished from the granulated ground substance. Plasmodium, within the sporangium, showing an early stage in the formation of the capillitium. The spirals are beginning to appear.

Fig. I4. Arcyria denudata fixed and stained in the same way. These cells are in the stalk, next the envelope. They will apparently take no part in spore formation. They show indications of cytolysis and contain but few mitochondria.

FIG. I5. Hemitrichia vesparium fixed and stained in the same way. Spores and cross and longitudinal sections of capillitium.

FIG. I6. Hemitrichia vesparium, same fixation and stain. A portion of the plasmodium flowing between the meshwork of the hypothallus. The mitochondria are elongated in the direction of movement. There is also a faint striation in the ground substance in the same direction. Some of the nuclei have well marked nucleoli.

FIG. I7. Arcyria denudata fixed in Regaud's fluid and stained with fuchsin and methyl green. The mitochondria are crimson. There are two immature spores which apparently contain a comparatively large amount of golden yellow pigment. The terminal enlargement of the capillitial thread also contains a series of granulations staining just as the mitochondria do.

FIG. I8. Hemitrichia clavata fixed in Regaud's fluid and stained with iron hematoxylin showing also internal granulation.

FIG. 19. Hemitrichia clavata fixed and stained in the same way. Plasmodium with cross section of capillitial thread and two types of nuclei, the smaller ones staining darkly and the larger ones lightly. 

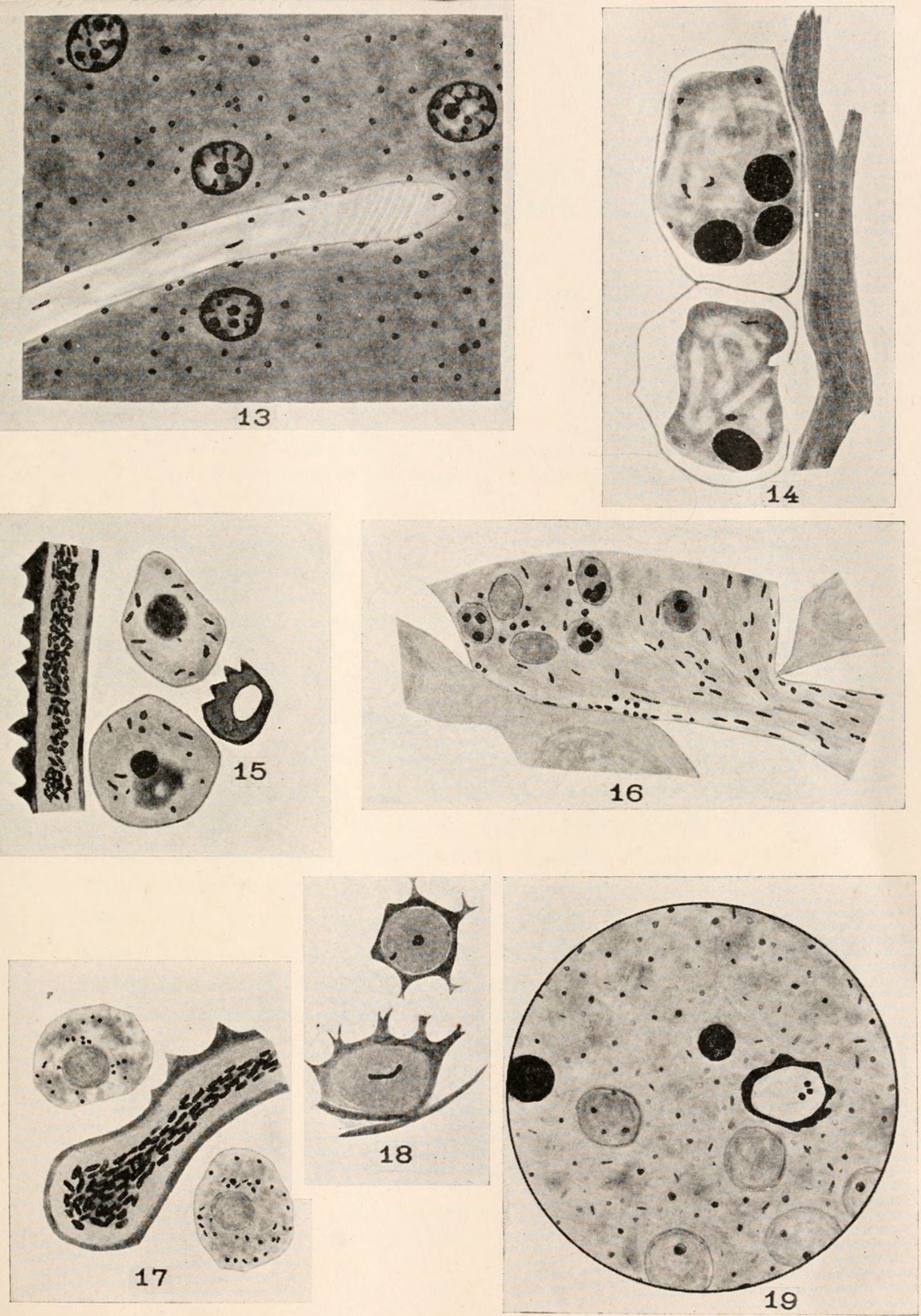

N. H. COWDFY. 



\section{A CONTRIBUTION TO THE PHYSIOLOGY OF WING DEVELOPMENT IN APHIDS. ${ }^{1}$}

GEORGE O. SHINJI,

University of Missouri, Columbia, Mo.

\section{CONTENTS.}

\begin{tabular}{|c|c|}
\hline I. & Introduction . \\
\hline II. & Experiments with the Rose Aphid. . \\
\hline III. & 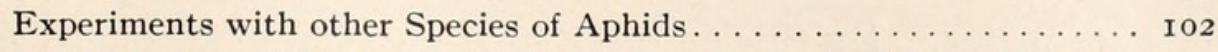 \\
\hline IV. & Period during which the Wing Development may be Controlled...... I04 \\
\hline V. & Strength of Magnesium Salts needed to Produce the Winged Aphids.. I05 \\
\hline VI. & Physical Factors: \\
\hline & I. Temperature...... \\
\hline & 2. Wilting of the Plant..... \\
\hline VII. & Morphological Studies......... \\
\hline JIII. & General Discussion ......................... I \\
\hline IX. & List of Aphids Experimented with $\ldots \ldots \ldots \ldots \ldots \ldots \ldots \ldots \ldots \ldots \ldots \ldots \ldots \ldots$ \\
\hline $\mathrm{X}$. & 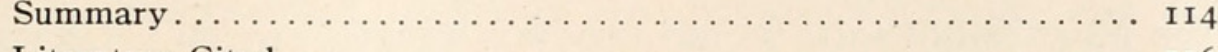 \\
\hline XI. & iterature Cited $\ldots \ldots \ldots \ldots \ldots \ldots \ldots \ldots \ldots \ldots \ldots \ldots \ldots$ \\
\hline
\end{tabular}

\section{INTRODUCTION.}

There are at least two closely related and equally interesting phenomena observed in the aphids, or plant-lice as they are commonly called. These are the development of apterous or alate forms, or both, as the offspring of either a winged or apterous viviparous female, and the parthenogenesis exhibited by them. The phenomena are not the result of alternation of generations, for it has been found by Slingerland (I893) and others that under certain favorable conditions a species of aphid might continue multiplying for a period of several years without producing a single male or winged individual.

Several attempts have been made to explain the phenomenon of wing-development in aphids. Shortage of food supply, it is believed, will usually produce winged aphids so that they may fly away to other plants where the supply of food has not been

${ }^{1}$ A thesis submitted in partial satisfaction of the requirements for the degree of Master of Science in the Graduate School of the University of California, April, I9I3. 
exhausted. Climatic changes, especially the approach of cooler weather, humidity, the wilting of host plants and many other factors have been regarded as possible causes of the appearance of the winged aphid. All explanations, however, have been advanced as the results of observations rather than as the results of experimental work.

The first experimental study of the problem was undertaken by Professor W. T. Clarke, of the University of California, in I9oI. He planted a rose twig bearing an apterous parthenogenetic female in each of a series of four-ounce tumblers. These he filled with washed sand, moistened with solutions of several salts or pure water. By this method, he could charge with any desired solution the sap-sucking insect through the plant. He was influenced, so he states, in his choice of chemicals by the chemical analysis of the ingredients of plants. Professor Clarke used sodium hydroxide, sodium phosphate, magnesium sulphate, magnesium chloride, and distilled water as a check. As a result of such experiments, he found that among these substances only the magnesium salts would produce winged aphids. Changes of temperature, he suggested, may not be a factor in the development of the wing in aphids.

In 1908 Professor C. W. Woodworth expressed his views on the problem. He stated that he believed that the wilting of plants might help develop the wing by retarding the growth of other parts and giving an even chance for the wing buds to develop.

Mr. J. D. Neiils, who studied the problem in I9I 2 , not only confirmed the findings of Clarke, but also pointed out a new fact that three days were usually required for the magnesium salts to produce a large number of winged aphids. Further, he found that the young aphids become winged, if they are subjected to the magnesium solutions within three days after birth.

Professor Clarke, and also Mr. Neiils, worked on a single species, namely, the common rose aphid, using the limited series of chemicals above mentioned. In order to determine whether other salts than those of magnesium would have a similar effect on the production of winged aphids, and also to determine whether the results of Clarke and Neiils were applicable to other species of aphids, I undertook an experimental study of the problem. 
Before going further, the writer wishes to acknowledge his indebtedness to Professor Woodworth, at whose suggestion the work was begun. His hearty thanks are also due to Professor E. Van Dyke, who, jointly with Professor Woodworth, gave valuable criticism and helpful suggestions during the progress of the investigation.

\section{Experiments with the Rose Aphid.}

These were partly to verify the findings of Professor Clarke and partly to make a more extensive test of the action of chemicals. The method of experimentation was that adopted and carried out by Professor Clarke. Sharp, clean sand was washed several times in running water, and then left to soak over night. The following day it was washed again with distilled water and after drying was ready for use. Four-ounce tumblers were then filled to one half of their depth with this sand and moistened with solutions of various chemicals. In each of these tumblers, a rose twig bearing from one to three viviparous females, usually apterous, was planted. Though Mr. Neiils pointed out the fact that three days are usually required for the magnesium salts to produce the largest number of winged aphids, it is not always necessary that the mother aphids be transferred to the twig that number of days after it is planted, to see the effect of the salts, for, as is also stated by Mr. Neiils, the young aphids become winged if they are subjected to magnesium salts within three days after birth. Consequently, I used the method previously described. A careful watch was kept of the twigs and when winged forms appeared, they were taken away, and the records kept of their appearance, as well as of the total number of young born. In my later experiments, the record was taken only once, when the first born had acquired the wings, because I had found that the tendency of the young aphids to produce wings could be accurately determined a certain number of days after birth.

I had thought that some other substances might also produce winged aphids. This belief was suddenly strengthened when I found, late in November, that a rose twig that was planted in an old tin can containing ordinary water, was infested with I 26 
winged and 2 apterous forms. This, I thought, was due to the presence of either tin or iron, because ordinary water, as will be seen elsewhere in the table, never produces more than 5 per cent. of winged forms. Consequently, I tested several salt solutions of the heavier metals and obtained the results which not only confirmed my belief, but also incidentally led to the finding of several new salts which could develop winged aphids.

Sugar and urea were also used in order to determine the effect of electrolytes as well as osmotic pressure. Urea never, or very rarely, produced winged individuals. The action of cane sugar caused rather confusing results, because the young ones produced on twigs, placed in the sugar solution that had been standing for a few days, remained apterous, while those on twigs in fresh sugar solution produced winged forms. These apparantly contradictory results, it was first thought, might be due to the decomposition of sugar by fermentation. That this explanation may be correct is indicated by the fact that both alcohol and acetic acid always produced apterous forms. From December 8 th on, the practice was followed of transferring the twig to a fresh solution every three days with uniform results.

When a stronger solution, about $m / 20$ of strontium bromide or strontium chloride was used, the tips of the twigs would dry out in the course of from 36 to 48 hours. Many aphids would fall off the twigs; those staying on the twigs would change to a dark salmon color, lose water, and finally dry upon the twig. Even in a solution of $m / 100-m / 300$ of strontium bromide, the twigs planted in it became darker in color and emitted the characteristic odor of strontium salts. About 99 per cent. of the young aphids remaining on the twig developed no wings.

Calcium chloride produced the same, but a weaker effect on the twig and also on the aphids. All aphids stayed on the twig charged with $m / 50$ solution of the salt, but remained apterous.

Owing to the very poisonous nature of the chemicals used, of ten the entire number of the young born on a twig charged with the solutions of mercury, lead or copper salts, would drop off before it could be determined whether they were winged or not. But the fact that some of them, happening to remain long enough, produced wings indicated that the solution had the wing-develop- 
TABLE I.

EXPERIMENTS With Rose ApHids.

\begin{tabular}{|c|c|c|c|}
\hline Date. & Chemicals. & $\begin{array}{c}\text { Total No. of Winged } \\
\text { Individuals. }\end{array}$ & $\begin{array}{l}\text { Total No. of Ap- } \\
\text { terous Individuals. }\end{array}$ \\
\hline \multirow[t]{10}{*}{ Up to October $20 \ldots$} & $\mathrm{CaCl}_{2} \ldots \ldots \ldots \ldots \ldots$ & 2 & 83 \\
\hline & $\mathrm{H}_{2} \mathrm{O}$, distilled $\ldots \ldots \ldots \ldots$ & o & 62 \\
\hline & $\mathrm{H}_{2} \mathrm{O}, \operatorname{tap} \ldots \ldots \ldots \ldots$ & 7 & I 12 \\
\hline & $\mathrm{KCl} \ldots \ldots \ldots \ldots \ldots \ldots$ & o & $5^{8}$ \\
\hline & $\mathrm{Na}_{2} \mathrm{CO}_{3} \ldots \ldots \ldots \ldots$ & 0 & 38 \\
\hline & $\mathrm{NaOH} \ldots \ldots \ldots \ldots \ldots$ & I & I 53 \\
\hline & $\mathrm{MgSO}_{4} \ldots \ldots \ldots \ldots \ldots$ & I 82 & 4 \\
\hline & 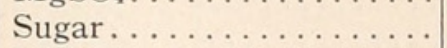 & I 8 & 34 \\
\hline & $\mathrm{SrCl}_{2} \ldots \ldots \ldots \ldots \ldots$ & I & 40 \\
\hline & Urea $\ldots \ldots \ldots \ldots \ldots$ & 2 & 32 \\
\hline \multirow[t]{12}{*}{ October $22 \ldots \ldots$} & $\mathrm{CaCl}_{2} \ldots \ldots \ldots \ldots \ldots$ & 0 & 42 \\
\hline & $\mathrm{H}_{2} \mathrm{O}$, distilled $\ldots \ldots \ldots \ldots$ & 0 & 24 \\
\hline & $\mathrm{KCl} \ldots \ldots \ldots \ldots \ldots \ldots$ & 0 & 42 \\
\hline & $\mathrm{NaH}_{p} \mathrm{O}_{4} \ldots \ldots \ldots \ldots$ & 0 & 28 \\
\hline & $\mathrm{MgSO}_{4} \ldots \ldots \ldots \ldots \ldots$ & 84 & I \\
\hline & $\mathrm{SrCl}_{2} \ldots \ldots \ldots \ldots$ & 0 & I 4 \\
\hline & Sugar . . . . . . . . & 36 & 25 \\
\hline & Urea ................ & 0 & 24 \\
\hline & $\mathrm{MgSO}_{4}-\mathrm{NaOH} \ldots \ldots \ldots$ & 22 & 2 \\
\hline & $\mathrm{MgSO}_{4}-\mathrm{Na}_{2} \mathrm{CO}_{3} \ldots \ldots \ldots$ & 30 & 5 \\
\hline & $\mathrm{MgSO}_{4}-\mathrm{Na}_{2} \mathrm{CO}_{3} \ldots \ldots$ & 2 & I6 \\
\hline & Acetic acid........... & 0 & 52 \\
\hline \multirow[t]{9}{*}{ November I I . . . . . } & Ordinary water......... & 2 & 24 \\
\hline & $\mathrm{KCl} \ldots \ldots \ldots \ldots \ldots$ & 0 & 27 \\
\hline & $\mathrm{NaOH} \ldots \ldots \ldots \ldots \ldots$ & o & 52 \\
\hline & $\mathrm{MgSO}_{4} \ldots \ldots \ldots \ldots \ldots$ & I 42 & I \\
\hline & Mg citrate . . . . . . . . & 28 & I \\
\hline & Sugar . . . . . . . . . & 82 & 0 \\
\hline & $\mathrm{SrCl}_{2} \ldots \ldots \ldots \ldots \ldots$ & I & I4 \\
\hline & 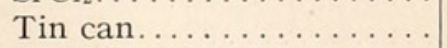 & 38 & 3 \\
\hline & $\mathrm{NaOH}-\mathrm{MgSO}_{4} \ldots \ldots \ldots$ & 48 & II \\
\hline \multirow{13}{*}{ December $2 \ldots .}$. & Alcohol . . . . . . . . . . & I & 48 \\
\hline & $\mathrm{CaCl}_{2} \ldots \ldots \ldots \ldots \ldots$ & o & I4 \\
\hline & $\mathrm{H}_{2} \mathrm{O} \ldots \ldots \ldots \ldots \ldots$ & 0 & 48 \\
\hline & $\mathrm{KCl} \ldots \ldots \ldots \ldots \ldots$ & 0 & 20 \\
\hline & $\mathrm{NaOH} \ldots \ldots \ldots \ldots \ldots$ & o & 48 \\
\hline & $\mathrm{Na}_{2} \mathrm{CO}_{3} \ldots \ldots \ldots \ldots$ & I & I 43 \\
\hline & $\mathrm{MgSO}_{4} \ldots \ldots \ldots \ldots$ & I 2 & o \\
\hline & Mg citrate . . . . . . . . & 24 & o \\
\hline & Tin can $\mathrm{H}_{2} \mathrm{O} \ldots \ldots \ldots$ & 62 & 0 \\
\hline & 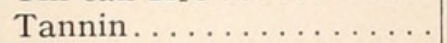 & 0 & I4 \\
\hline & $\mathrm{SrCl}_{2} \ldots \ldots \ldots \ldots \ldots$ & 0 & 28 \\
\hline & Creek water............. & 3 & 87 \\
\hline & Urea ................. & o & I 8 \\
\hline \multirow{7}{*}{ December $18 \ldots . .}$. & $\mathrm{SrCl}_{2} \ldots \ldots \ldots \ldots \ldots \ldots$ & . 33 & I \\
\hline & $\mathrm{CuSO}_{4} \ldots \ldots \ldots \ldots \ldots$ & I 2 & 0 \\
\hline & $\mathrm{Hg}\left(\mathrm{NO}_{3}\right)_{2} \ldots \ldots \ldots \ldots$ & 6 & I \\
\hline & $\mathrm{NiSO}_{4} \ldots \ldots \ldots \ldots \ldots$ & 86 & 0 \\
\hline & $\mathrm{ZnCl}_{2} \ldots \ldots \ldots \ldots \ldots$ & 38 & I \\
\hline & $\mathrm{SnCl}_{4} \ldots \ldots \ldots \ldots$ & 92 & 0 \\
\hline & $\mathrm{AgNO}_{3} \ldots \ldots \ldots \ldots \ldots$ & I I & 0 \\
\hline \multirow{3}{*}{ January 20, I9I3... } & $\mathrm{Hg}\left(\mathrm{NO}_{3}\right)_{2} \ldots \ldots \ldots \ldots$ & & \\
\hline & $\mathrm{MgSO}_{4} \ldots \ldots \ldots \ldots \ldots$ & 8 & 0 \\
\hline & $\mathrm{NiSO}_{4} \ldots \ldots \ldots \ldots \ldots$ & I $4 \mathrm{I}$ & 0 \\
\hline
\end{tabular}




\begin{tabular}{|c|c|c|c|}
\hline Date. & Chemicals. & $\begin{array}{l}\text { Total No. of Winged } \\
\text { Individuals. }\end{array}$ & $\begin{array}{l}\text { Total No. of Ap- } \\
\text { terous Individuals. }\end{array}$ \\
\hline \multirow{11}{*}{ January 20, I9I $3 \ldots$} & $\mathrm{PbCl}_{2} \ldots \ldots \ldots \ldots \ldots$ & 2 & 0 \\
\hline & $\mathrm{SbCl}_{3} \ldots \ldots \ldots \ldots$ & I 8 & 2 \\
\hline & $\mathrm{SnCl}_{4} \ldots \ldots \ldots \ldots \ldots$ & I 48 & 4 \\
\hline & $\mathrm{Na}_{2} \mathrm{CO}_{3} \ldots \ldots \ldots \ldots$ & o & 53 \\
\hline & $\mathrm{NaOH} \ldots \ldots \ldots \ldots \ldots$ & 0 & 38 \\
\hline & Urea ............. & 0 & I4 \\
\hline & Sugar.............. & I & 85 \\
\hline & Alcohol.............. & o & 62 \\
\hline & Tannin .............. & I & I4 \\
\hline & Alum............ & I & 82 \\
\hline & $\mathrm{H}_{2} \mathrm{O} \ldots \ldots \ldots \ldots \ldots$ & 0 & 28 \\
\hline \multirow[t]{7}{*}{ February $7 \ldots \ldots$} & $\mathrm{CuSO}_{4} \ldots \ldots \ldots \ldots \ldots$ & 5 & o \\
\hline & $\mathrm{KCl} \ldots \ldots \ldots \ldots \ldots$ & 0 & 59 \\
\hline & $\mathrm{H}_{2} \mathrm{O} \ldots \ldots \ldots \ldots \ldots$ & 0 & 48 \\
\hline & $\mathrm{NiSO}_{4} \ldots \ldots \ldots \ldots \ldots \ldots$ & 62 & 0 \\
\hline & $\mathrm{NaOH} \ldots \ldots \ldots \ldots \ldots$ & o & 48 \\
\hline & $\mathrm{SnCl}_{4} \ldots \ldots \ldots \ldots$ & I I I & I \\
\hline & $\mathrm{ZnCl}_{2} \ldots \ldots \ldots \ldots \ldots$ & 2 & \\
\hline \multirow[t]{14}{*}{ February 2 I . . . . } & $\mathrm{CaCl}_{2} \ldots \ldots \ldots \ldots \ldots$ & & $5^{2}$ \\
\hline & $\mathrm{CuSO}_{4} \ldots \ldots \ldots \ldots$ & 5 & I \\
\hline & $\mathrm{AgNO}_{3} \ldots \ldots \ldots \ldots \ldots$ & I 2 & 0 \\
\hline & $\mathrm{HgCl}_{2} \ldots \ldots \ldots \ldots \ldots$ & I 7 & 4 \\
\hline & $\mathrm{H}_{2} \mathrm{O} \ldots \ldots \ldots \ldots \ldots$ & I & 148 \\
\hline & $\mathrm{KCl} \ldots \ldots \ldots \ldots \ldots \ldots$ & I & I 4 \\
\hline & $\mathrm{SrCl}_{2} \ldots \ldots \ldots \ldots \ldots$ & o & 29 \\
\hline & $\mathrm{Na}_{2} \mathrm{CO}_{3} \ldots \ldots \ldots \ldots$ & o & 24 \\
\hline & $\mathrm{SnCl}_{4} \ldots \ldots \ldots \ldots \ldots$ & I 84 & I \\
\hline & $\mathrm{MgSO}_{4} \ldots \ldots \ldots \ldots \ldots$ & I 7 & I \\
\hline & $\mathrm{PbCl}_{2} \ldots \ldots \ldots \ldots \ldots$ & IO & 2 \\
\hline & $\mathrm{ZnCl}_{2} \ldots \ldots \ldots \ldots \ldots$ & 8 & I \\
\hline & Alcohol.............. & I & 42 \\
\hline & Acetic acid.......... & 0 & I 4 \\
\hline \multirow{12}{*}{ March $5 \ldots \ldots \ldots$} & $\mathrm{AgNO}_{3} \ldots \ldots \ldots \ldots \ldots$ & 2 & o \\
\hline & $\mathrm{CaCl}_{2} \ldots \ldots \ldots \ldots \ldots$ & 0 & 33 \\
\hline & $\mathrm{KCl} \ldots \ldots \ldots \ldots \ldots$ & 2 & 54 \\
\hline & $\mathrm{H}_{2} \mathrm{O}$, surface $\ldots \ldots \ldots \ldots$ & 2 & 142 \\
\hline & $\mathrm{H}_{2} \mathrm{O}$, distilled......... & o & 22 \\
\hline & $\mathrm{HgCl}_{2} \ldots \ldots \ldots \ldots \ldots$ & 8 & I \\
\hline & $\mathrm{MgSO}_{4} \ldots \ldots \ldots \ldots \ldots$ & $3 I$ & I \\
\hline & $\mathrm{NiSO}_{4} \ldots \ldots \ldots \ldots \ldots \ldots$ & IIO & 2 \\
\hline & $\mathrm{Na}_{2} \mathrm{CO}_{3} \ldots \ldots \ldots \ldots \ldots$ & 0 & 87 \\
\hline & $\mathrm{SrCl}_{2} \ldots \ldots \ldots \ldots \ldots$ & 0 & 42 \\
\hline & Sugar . . . . . . . . & I & I 5 \\
\hline & Urea ............... & 2 & I 8 \\
\hline \multirow{12}{*}{ March 20} & $\mathrm{AgNO}_{3} \ldots \ldots \ldots \ldots \ldots$ & I 4 & 0 \\
\hline & $\mathrm{CaCl}_{2} \ldots \ldots \ldots \ldots \ldots$ & 0 & 48 \\
\hline & $\mathrm{H}_{2} \mathrm{O}$, distilled.......... & 6 & I 4 \\
\hline & $\mathrm{KCl} \ldots \ldots \ldots \ldots \ldots$ & 0 & $6 \mathrm{I}$ \\
\hline & $\mathrm{SrCl}_{2} \ldots \ldots \ldots \ldots$ & 0 & 32 \\
\hline & $\mathrm{MgSO}_{4} \ldots \ldots \ldots \ldots$ & 36 & I \\
\hline & $\mathrm{Mg}$ citrate.$\ldots \ldots \ldots \ldots$ & 44 & 0 \\
\hline & $\mathrm{Na}_{2} \mathrm{CO}_{3} \ldots \ldots \ldots \ldots$ & I & 20 \\
\hline & $\mathrm{NiCl}_{2} \ldots \ldots \ldots \ldots \ldots$ & 98 & I \\
\hline & $\mathrm{SnCl}_{4} \ldots \ldots \ldots \ldots \ldots$ & I 12 & 3 \\
\hline & Urea .............. & I & I6 \\
\hline & Sugar . . . . . . . . . & 218 & I \\
\hline
\end{tabular}


PHYSIOLOGY OF WING DEVELOPMENT IN APHIDS.

\begin{tabular}{|c|c|c|c|}
\hline Date. & Chemicals. & $\begin{array}{l}\text { Total No. of Winged } \\
\text { Individuals. }\end{array}$ & $\begin{array}{l}\text { Total No. of Ap- } \\
\text { terous Individuals. }\end{array}$ \\
\hline April $3 \ldots$. & 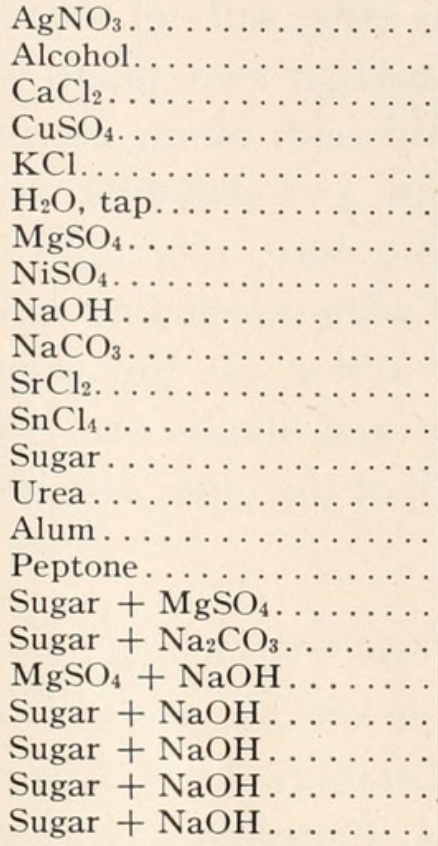 & $\begin{array}{r}\mathrm{I} 2 \\
0 \\
6 \\
\mathrm{I} 2 \\
0 \\
2 \\
32 \\
\mathrm{I} 82 \\
0 \\
0 \\
0 \\
\mathrm{I} 16 \\
\mathrm{I} 18 \\
0 \\
0 \\
\mathrm{I} \\
0 \\
\mathrm{I} \\
0 \\
0 \\
0 \\
2 \\
0\end{array}$ & $\begin{array}{r}0 \\
\text { I36 } \\
62 \\
0 \\
47 \\
48 \\
0 \\
\text { I } \\
84 \\
92 \\
24 \\
0 \\
\text { I } \\
3 \text { I } \\
\text { I6 } \\
\text { I } 5 \\
24 \\
82 \\
62 \\
40 \\
\text { I } 2 \\
\text { I } 2 \\
42\end{array}$ \\
\hline
\end{tabular}

The following is the summary of the foregoing data.

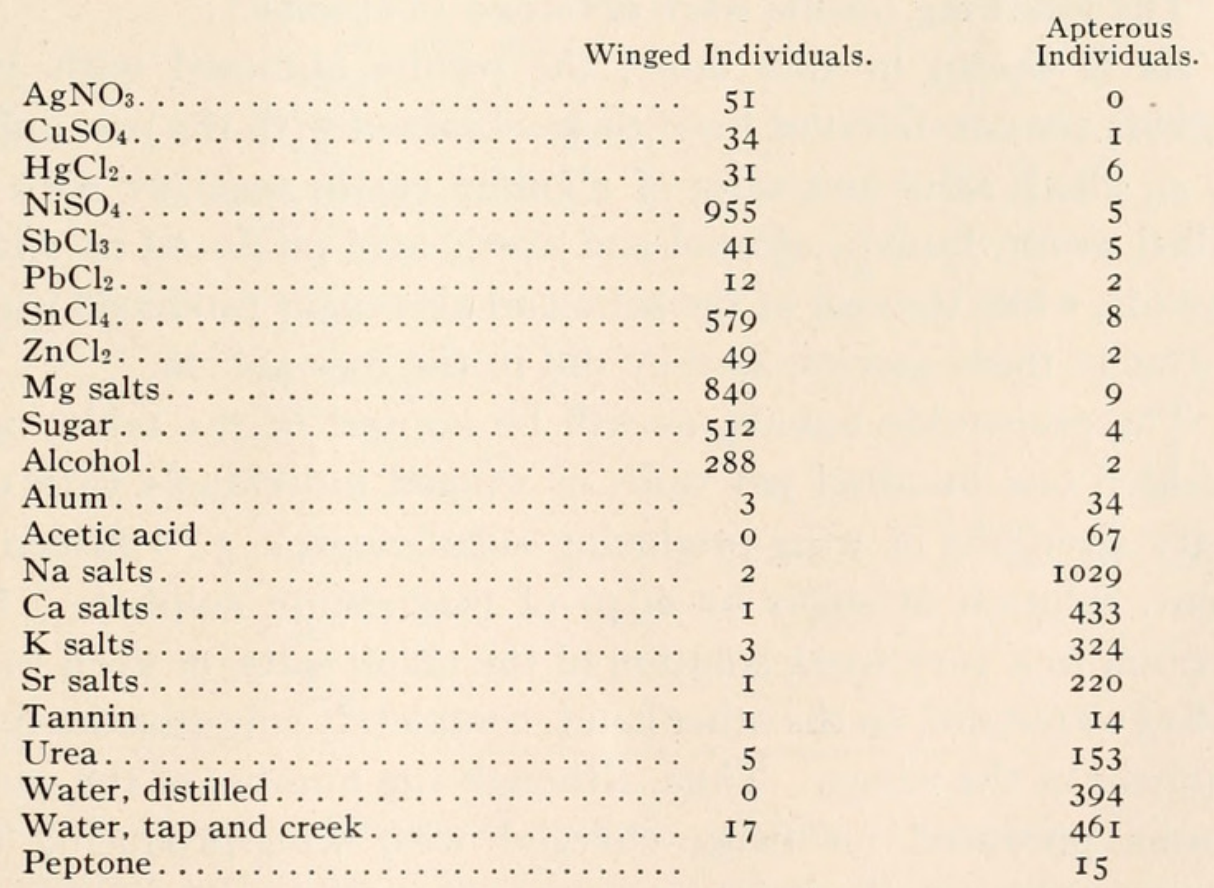

ing qualities. Only a few drops of the normal solutions of these salts were added to the $5 \mathrm{c}$. c. of distilled water, in most of my experiments. 
The above results not only verified the findings of Professor Clarke, but also led to the discovery of new substances. In addition to the magnesium salts, salts of antimony, nickle, tin, mercury, lead, zinc and also sugar were found to produce winged aphids; while alcohol, acetic acid, alum, tannin, salts of strontium, potassium and calcium, and also urea were shown to have no effect. These substances may, therefore, be classified into wing-developing and non wing-developing substances, respectively, according to their action on the wing buds. To the former class, belong the salts of alkalis and the alkaline earths, while to the latter belong all of the other salts mentioned, as well as sugar.

\section{Experiments with Other Species of Aphids.}

The studies thus far mentioned concerned only the common rose aphis. Do these substances have a similar effect upon other species of aphids? I, therefore, instituted another series of experiments, using the same methods as were employed in the course of the development in the rose aphid.

The following results were obtained (Table II.):

As is shown in this table, the results obtained with these aphids are not different from those obtained with the rose aphids, $i$. e., alkali salts and salts of alkaline earth, together with distilled water, tannin, alcohol and acetic acid produced no winged aphids, while the rest of the salts and also sugar produced winged forms in these species, as they did in the rose aphids.

The periwinkle aphids, as will be noticed in the table, never yielded one hundred per cent. of winged individuals with ordinary strengths of wing-producing substances; $e$. g., a fifteen per cent. solution of sugar or $m / 40$ of magnesium sulphate. Subjection to a very weak solution of the alkali salts, or even to distilled water, did, on the other hand, completely suppress the development of the wings. Thus, although the number of the winged forms produced on twigs charged with wing-producing substances was small, their appearance must be accredited to the presence of these substances. The common aphids on Sonchus, on the mustard and on the German ivy (Senecio sp.) were found to develop their wings after subjection to very weak solutions of 
TABLE II.

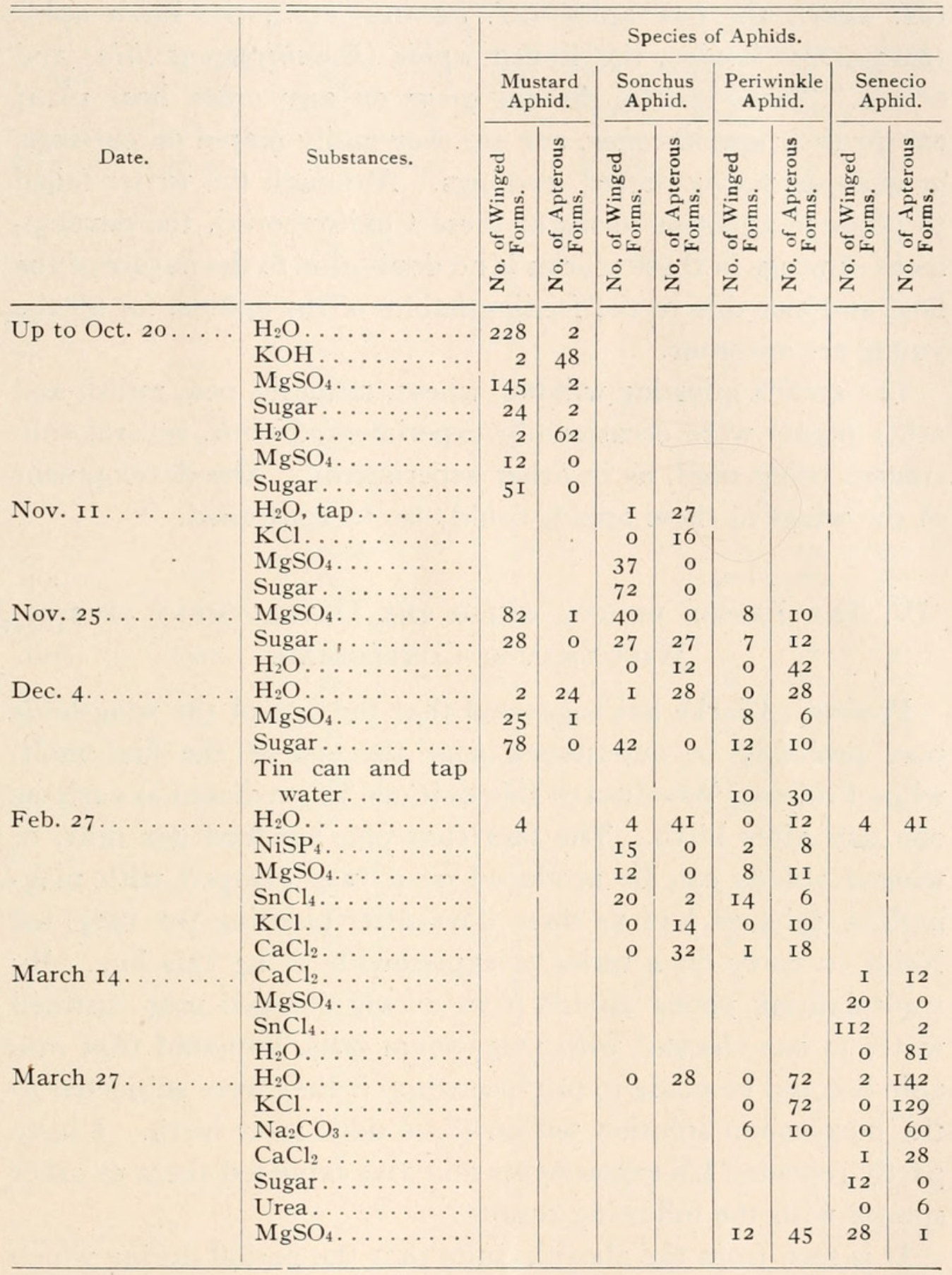

any of the wing-producing substances. Thus, it is evident that there exists a variation in the degree of susceptibility among the species of aphids.

It might also be well to add here that in several species of aphids belonging to the tribe Chaitophorini no apterous viviparous females have as yet been found. Such, for example, is the 
case with the chestnut aphis (Myzocalis castance), the ulmus aphis (M. ulmi), the oak aphis ( $M$. quercus, etc.), the birch aphis (Euceraphis betula), the linden aphis (Eucallipterous tilic) and others. These species do not grow on any other host plant except their specific ones, nor are they easily reared on cuttings, or even on young potted seedlings. Although the writer failed to produce apterous forms of these Chaitophorini, the development of wings in these species is no doubt due to the nature of the host and also due to the feeding habits of the aphids, for all the young are apterous.

The aphids infesting willows, wheat, clematis, pea, radish and other plants were occasionally experimented with, several substances being used, as in other experiments. The development of the wings in these aphids could also be controlled.

\section{The Period during which the Development of the Wings may BE Controlled.}

Professor Clarke has suggested that the fate of the wing-buds may probably be determined near the end of the first molt, while Professor Woodworth thinks it can be predicted as early as one day after birth. The fact that one hundred per cent. of winged aphids can be produced on a twig charged with magnesium salts as late as three days after planting the twig, led Neiils to carry on a series of experiments along this line. By transplanting young aphids from a twig charged with distilled water to one charged with magnesium salts, he found that rose aphids could be made to produce wings if they were subjected to the magnesium solution within three days after birth. I have partly repeated his experiments and also extended them to other species with the following results:

It is seen from the above results that the period during which the development of the wing-buds can be controlled varies with the species. I have also observed in the course of my experiments that the aphids infesting the German ivy (Senecio sp.) develop the wing-buds within sixty hours after their birth. 
TABLE III.

\begin{tabular}{|c|c|c|c|c|c|c|c|c|}
\hline Date. & $\begin{array}{l}\text { Name of } \\
\text { Plant. }\end{array}$ & $\begin{array}{l}\text { Total } \\
\text { No. of } \\
\text { Young } \\
\text { Trans. } \\
\text { ferred. }\end{array}$ & $\begin{array}{l}\text { Sol. on } \\
\text { which } \\
\text { Young } \\
\text { were } \\
\text { Born. }\end{array}$ & $\begin{array}{l}\text { No. of } \\
\text { Days } \\
\text { left on } \\
\mathrm{H}_{2} \mathrm{O} \text {. }\end{array}$ & $\begin{array}{l}\text { Sol. to } \\
\text { which they } \\
\text { were Trans- } \\
\text { ferred. }\end{array}$ & $\begin{array}{l}\text { No. that } \\
\text { Re- } \\
\text { mained } \\
\text { Wing- } \\
\text { less. }\end{array}$ & $\begin{array}{c}\text { No, that } \\
\text { De- } \\
\text { veloped } \\
\text { Wings. }\end{array}$ & $\begin{array}{l}\text { Per } \\
\text { Cent. of } \\
\text { Winged } \\
\text { Forms. }\end{array}$ \\
\hline \multirow{6}{*}{$\begin{array}{l}\text { Oct. } 8-\text { I } 8 \text {, } \\
\text { I9I } 2\end{array}$} & Rose & IO & $\mathrm{H}_{2} \mathrm{O}$ & I & $\mathrm{MgSO}_{4}$ & I & 9 & 90 \\
\hline & “" & IO & “" & 2 & “ & 0 & IO & 100 \\
\hline & “ & Io & “ & 3 & “ & 0 & IO & IOO \\
\hline & “" & IO & “ & 4 & “ & 2 & 8 & 80 \\
\hline & “ & IO & “" & 5 & “" & 9 & I & Io \\
\hline & “ & IO & ". & 6 & “ & 9 & I & IO \\
\hline \multirow{12}{*}{$\begin{array}{l}\text { Nov. } 30- \\
\text { Dec. } 9\end{array}$} & "“ & IO & “ & I & “" & I & 9 & 90 \\
\hline & “ & IO & “ & 2 & “" & o & IO & IOO \\
\hline & “ & Io & “" & 3 & “" & o & IO & 100 \\
\hline & “ & IO & “" & 4 & “" & 3 & 7 & 70 \\
\hline & “" & Io & “ & 5 & “ & 8 & 2 & 20 \\
\hline & “ & IO & “، & 6 & “ & 9 & I & Io \\
\hline & Sonchus & IO & “ & I & “ & 0 & IO & IOO \\
\hline & " & IO & “ & 2 & “" & 0 & IO & IOO \\
\hline & “ & Io & “، & 3 & “" & 0 & IO & IOO \\
\hline & “ & IO & “. & 4 & “. & 0 & IO & IOO \\
\hline & “" & Io & “، & 5 & ““ & o & IO & IOO \\
\hline & “" & IO & "، & 6 & “. & 3 & 7 & 70 \\
\hline \multirow{22}{*}{$\begin{array}{l}\text { Feb. Io, } \\
\text { I9I3 }\end{array}$} & Rose & & “ & I & “" & 0 & IO & IOO \\
\hline & " & I0 & “. & 2 & “ & 0 & IO & IOO \\
\hline & “ & Io & “ & 3 & “" & I & 9 & 90 \\
\hline & “ & IO & “ & 4 & “ & 0 & IO & IOO \\
\hline & “ & IO & “، & 5 & “ & 2 & 8 & 80 \\
\hline & “ & IO & “، & 6 & “. & IO & 0 & 0 \\
\hline & “" & IO & “ & 8 & “ & 9 & I & IO \\
\hline & Sonchus & 5 & “" & I & “" & & & \\
\hline & “ & 5 & “" & 2 & “ & & & \\
\hline & “ & 5 & “" & 3 & “. & & & \\
\hline & “" & 5 & “" & 4 & “" & 0 & Io & IOO \\
\hline & “" & 5 & “. & 5 & “" & 0 & IO & 100 \\
\hline & “. & 5 & “. & 6 & “. & 0 & IO & IOO \\
\hline & ، & 5 & “. & 8 & “. & & 2 & 20 \\
\hline & Mustard & 5 & “. & 9 & “. & & 0 & 0 \\
\hline & . & $\begin{array}{l}5 \\
5\end{array}$ & ." & I & “، & & & \\
\hline & “ & 5 & “" & 3 & “. & & & \\
\hline & “ & 5 & “" & 4 & “" & & IO & 100 \\
\hline & “" & 5 & “ & 5 & “” & & IO & IOO \\
\hline & “ & 5 & “ & 6 & “" & & IO & IOO \\
\hline & “ & 5 & “ & 8 & “ & & 8 & 80 \\
\hline & “" & 5 & “ & 9 & “" & & 0 & 0 \\
\hline
\end{tabular}

V. Strength of Magnesium Sulphate needed to Produce the Winged Aphids.

It must be conceded that no accurate methods of measuring the amount of any solution can be devised, for the reason that the solution must first pass through the plant tissue before it reaches the body of the insect. For the purpose of obtaining 
some idea of the amount of the wing-developing substances to be effective in the development of the wing-buds, I instituted a series of experiments. In these experiments, the solutions of the magnesium sulphate, of various strengths, were poured directly into a series of tumblers, in each of which a rose twig, bearing a viviparous female, had been placed.

TABLE IV.

\begin{tabular}{|c|c|c|c|c|}
\hline Date. & Solutions. & No. Winged. & No. Apterous. & Per Cent. Winged. \\
\hline \multirow[t]{7}{*}{ Oct. $9 \ldots$. } & $m / 2$ & 8 & 2 & 80 \\
\hline & $m / 3$ & 3 & o & 100 \\
\hline & $m / 4$ & 5 & 0 & 100 \\
\hline & $m /$ Io & I3 & 0 & IOO \\
\hline & $m / 20$ & 33 & 0 & IOO \\
\hline & $m /$ I OO & I6 & I & 92 \\
\hline & $m / 200$ & I 12 & 4 & 95 \\
\hline \multirow[t]{6}{*}{ Dec. I $2 \ldots$} & $m / 20$ & 6 & I & 86 \\
\hline & $m / 20$ & 5 & 0 & I00 \\
\hline & $m / 80$ & I 8 & I & 90 \\
\hline & $\mathrm{m} / 320$ & 38 & I & 97 \\
\hline & $m / 50$ & IO & 0 & 100 \\
\hline & $m /$ I 00 & 22 & I & 95 \\
\hline \multirow{5}{*}{ Feb. $25 \ldots$} & $m /$ I OO & 52 & o & IOO \\
\hline & $m / 200$ & 52 & o & IOO \\
\hline & $m / 400 ?$ & I 2 & 2 & 90 \\
\hline & $m / 500 ?$ & $2 \mathrm{I} 2$ & 4 & 98 \\
\hline & $m /$ I $000 ?$ & I 13 & 6 & 96 \\
\hline
\end{tabular}

As will be seen from the table, I have been unable as yet to reach the lowest strength at which the majority of the aphids born on the twig would remain apterous. The table, however, suggests that this minimum amount may lie beyond the strength of an $m /$ IOOO solution.

It may also be added here that the susceptibility to the chemicals varies greatly with the species. Euceraphis betulce on the birch tree growing on a sunny soil rarely or never produces apterous forms, while a considerable number of Calaphis betulacolens infesting the same host become winged. Macrosiphum rose also produce alate forms even on a relatively younger shoot, but it is utterly impossible to raise winged Myzus persica on a similar host without the application of a wing-developing substance.

\section{On the Physical Factors.}

I. Temperature.-No special experiment for determining the effect of temperature upon the development of the wings has 
been made. A part of my experiments, and also those of Professor Clarke, were carried on in our laboratory where a nearly uniform temperature was kept throughout a period of several days. A larger part of my work was done in an old greenhouse where the change of temperature between day and night was exceedingly great. I have also done a part of my work out of doors. In all of these cases, only a very few of the winged aphids appeared on the twigs charged with any of the non-wingdeveloping substances. Professor Clarke stated that he had subjected aphid-infested twigs charged with distilled water to a sudden change of temperature from $80^{\circ} \mathrm{F}$. to $30^{\circ} \mathrm{F}$., and had observed no effect on the wing development. These observations, therefore, establish the fact, I believe, that changes in temperature have no effect on the production of winged forms.

The popular conception that the approach of cold weather makes winged aphids appear may be explained in the following manner. Plants mature either at the time when the cold weather sets in or previous to that period. They also manufacture, through the agency of their leaves and under the influence of sunlight, starch, which at this maturing period is changed to sugar and stored away in other parts of the plant. This sugar is the most common wing-developing substance, as we have seen. Therefore, the aphids produce wings at the approach of cold weather, not because of the low temperature, but because of the presence of sugar in the plant tissues at that time.

2. Wilting of the Plant.-Professor Woodworth has pointed out that when the plants, especially cabbages on which he has made extensive observations, are badly infested with aphids and begin to wilt, there was a decrease in the birth rate of the insects and a "spontaneous appearance of the aphids with wingpads was noticed." His explanation of this phenomenon is that the wilting of plants probably causes an effect similar to that produced by the magnesium salts, that is, it makes it possible for the wing-buds to have an even chance with the rest of the body to develop. Under more favorable conditions, he suggests that the growth of the wing-fundaments might be retarded on account of the faster growth of the other parts of the body. A morphological study bearing upon this point is pre- 
sented farther on, but I shall now attack the problem by experimental means.

The weight of a number of fresh rose twigs, similar to those used in my other experiments, was recorded. One of these twigs was then planted in a tumbler containing distilled water, and one in a tumbler containing calcium chloride, in the manner already described. Three days later, the twigs were taken out of the tumblers, placed on a paper, and left to dry from four to twentyfour hours. The second or dried weight of each was recorded, and the twigs then replaced in their respective tumblers. Three to four apterous viviparous females were then transferred to each of them, and a careful watch kept for the young. The following tabulation shows the results obtained:

TABLE V.

The Effects from the Wilting of the Plant.

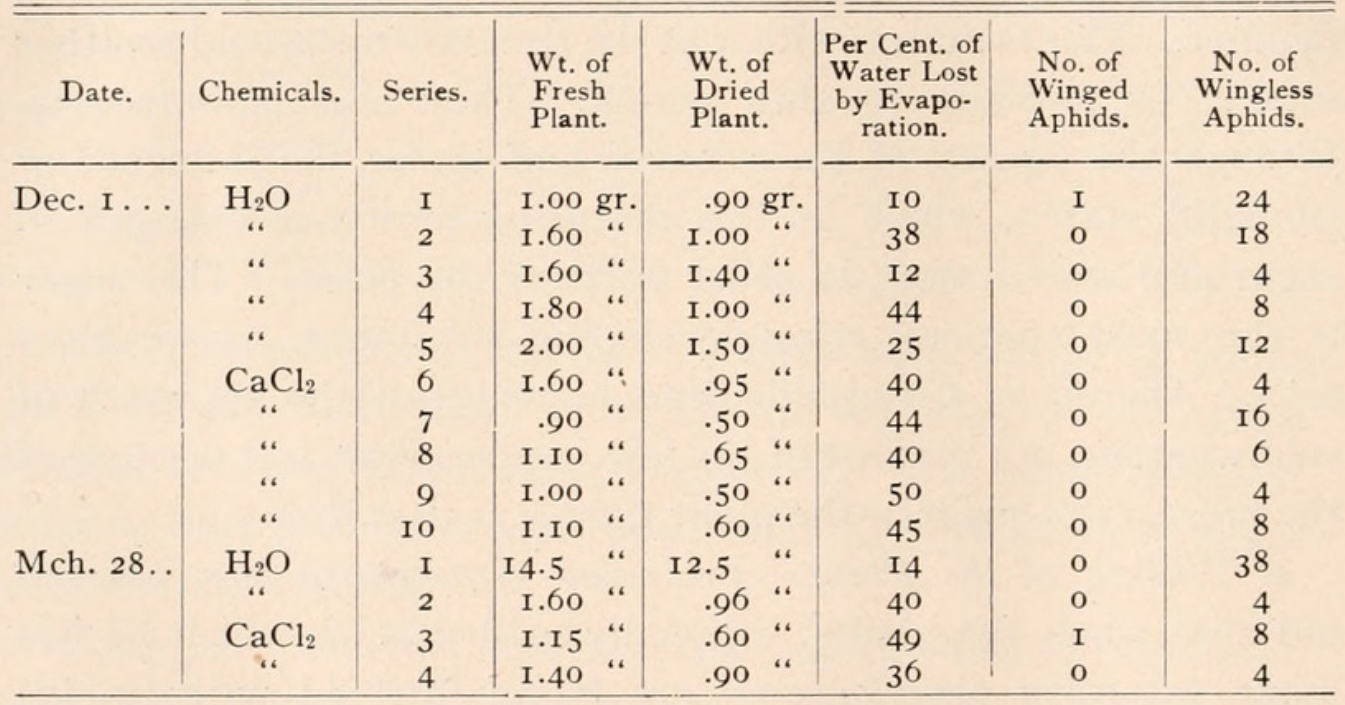

Thus the mere wilting of the plant is not a factor in the production of the winged aphids. The drying out of the plant may, however, indirectly help to produce the winged insects by concentrating the ingredients in the plant tissues.

\section{Mor phological Study.}

The young female aphids are, externally at least, well developed at the time of their birth. They have three pairs of legs and a pair of antennæ as stout as their mother's, but shorter. A pair of so-called honey-tubes and the caudal appendage are also 
present. There is, however, no external indication of the wings or of their buds. The body is almost columnar, with a constriction back of the head, but with no marked differentiation between the thorax and abdomen.

In those individuals which ultimately become winged, the second and the third thoracic segments begin to swell laterally as well as dorso-ventrally. The swollen thorax is ordinarily noticeable at the end of the first ecdysis in the case of the rose aphids. Usually after the second, yet occasionally after the third ecdysis, in the case of the mustard aphis, a pair of hyaline wing-pads protrude from each side of the second and third thoracic segments. At the following ecdysis, the wing-pads become unfolded and the adult insect results. In those forms which remain apterous, no constriction between the thorax and abdomen occurs.

Other structural differences noticeable between the apterous and alate viviparous females of the common rose aphid, Macrosiphum rosa (L.), may be tabulated as follows:

Winged Viviparous Female.

Color-Dorsal marking present.

Length $-2.2 \mathrm{~mm}$.

Antenne-Articles I to VI dark throughout.

Sensoria on $I I I$-More than 60 found throughout the entire length.

Color of Cornicle-Dark throughout.
Wingless Viviparous Female.

Dorsal marking absent.

$2.7 \mathrm{~mm}$.

Only I, II, and VI dusky.

About 12, all being found near the basal portion.

Dark with lighter rings near the base and apex.

These are some of the more prominent differences. Minor differences, as, for example, the relative length, shape, size, etc., of the cornicle; cauda, antenna, etc., are numerous and cannot be enumerated here. It follows, then, that the factor which is responsible for the production of either the apterous or the alate forms not only determines the fate of the wings, but also causes other morphological changes as above mentioned.

Although no special effort was made to study the histological differences between the two forms, the sectioned material showed that there is a less amount of muscles and ectodermal cells, but more of fat body in the apterous form as compared with the alate individual. 


\section{ViII. General Discussion.}

As the result of our experiments, we have been able to distinguish two groups of substances, one that produces and the other that does not produce winged aphids. Clarke (I90I), Neiils (I9I2) and Woodworth (I908) held that the presence of magnesium in the plant tissue might be responsible for the phenomenon under discussion. My experiments have shown that the magnesium salts are not the sole substances that produce the winged aphids. Other substances, namely, the salts of heavy metals, had a similar effect on the development of wings. Consequently, it becomes clear that what is really responsible for the appearance of the winged aphids is the excess of magnesium and other wing-producing substances over the non-wingproducing substances contained in the plant sap.

Morgan (I909) presented an analysis of the leaves of plants, the rose and the maple, at two different seasons of the year, namely, June and October. His table showed, as we should expect, a marked difference in the amount of ash contained in the leaves of the two kinds of plants at the same time of the year. A similar difference was also pointed out in the case of the same plant at two different seasons of the year. The chemical analysis of plants is, then, in accordance with the general observation in the field that the alate forms are more abundant during the autumn than in the spring and that the winged forms of the same species are more abundant on one kind of plant than on another even at the same period of the year.

Morgan's table is also valuable in estimating the proximate amount of wing-developing substances that may be effective. According to the analysis, the percentages of ash contained in the fresh rose leaves in October and June are 3.6I and 3.69, respectively. The difference between these two figures, or 0.54I per cent., may then be regarded as the maximum amount of the wing-developing substances which would be effective when added to the spring leaves.

I have already given an explanation of why the drying of plants produced alate forms as reported by Woodworth (I908). However, I did not discuss the secondary effect of temperature on the development of the wing. Recently Ewing (I9I6) stated 
that a great number of alate forms would appear under a certain optimum temperature in the form he had been experimenting with, namely, Aphis avence. I have already shown that the temperature had nothing to do with causing the appearance of the winged forms under a well-controlled environment. Ewing's result, like that of Woodworth on the effect of dryness, was obtained under natural conditions, with perhaps little attention paid to the chemical constituents of the host plant. It is strongly doubted whether any winged forms would have appeared, had they been reared under his optimum temperature but on the host charged with any one of the non-wingdeveloping substances. In fact, I believe that the appearance of winged forms under his "optimum temperature" is due, not so much to the direct action of heat as such, but indirectly to either an increase in the solubility of the wing-developing substances or to a decrease of the non-wing-developing substances.

Tannreuther (1907), who has made extensive observations on the life history as well as the genetic cycle of Pterocomma salicis and P. salicicola, says: "The prevalent idea that the development of aphis is unstable and controlled directly by external conditions is certainly very misleading especially in the idea that unfavorable conditions or lack of food is a direct cause for the appearance of the winged and sexual forms. We find in the species studied that just the reverse is true, and that the greatest number of winged forms are found in the second parthenogenetic generation; here in some instances ninety-five per cent. may become winged, especially those found on the rose in good condition which furnished an abundance of food." Pterocomma bicolor and $P$. rufurum found in the vicinity of the University of California campus, however, reacted to the chemicals, but they were peculiar in that they did not produce sexual forms at the sixth generation.

Now I come to the consideration of the question which was set forth by Tannreuther (1907), to wit, "Why some of the hypodermic cells of the thorax begin to divide, emarginate and form the adult wings in a few days." According to Anderson (I 893) and others there are two groups of salts, one that excites the muscles and one that has little effect upon them. Our so-called 
wing-developing substances correspond with the former, and the non-wing-developing substances to the latter. Further, so far as these non-wing-developing substances are concerned, Herbst (I906), Loeb (I907), and others have proven them to be injurious to other classes of animals. For example, Herbst (I906) found that the addition of potassium salts to sea water suppressed the development of the arms of the Echinus larvæ. These investigators have also found that the development of the alimentary canal of the Echinus larva was impossible in magnesium-free sea water. Again, Fischer (1903) and others have proven that magnesium salts counteract the effect of saline purgative. All these results obtained with other animals by various investigators suggest that wing-developing and non-wing-developing substances exert, respectively, characteristic action on the organic matter. We have at least two evidences that tend to show that in all probability the two phenomena of the appearance of the winged or wingless individuals may be due to the physiological actions osmosis and surface tension. One of these is the presence of more of the fat cells, which are derived from mesoderm cells, in the apterous forms than in the alate forms, and the other is the fact that the cells of the apterous forms are slightly larger than those of the alate forms. The first of these evidences suggests the probable degeneration of muscle and probably nerve cells at the time when the wing cells are in the process of differentiation. The degeneration may, it must be said, be due to the increase in the cytoplasmic area of the cell and the subsequent loss of the coördination between the nucleus and its surrounding cytoplasm, as is manifested in the case of the fat body. The difference in the size of the two forms may not only strengthen the view just presented, but also explains why the winged forms resemble the male, and the apterous, the sexual females; for the two winged forms, the male and the alate viviparous females are much more highly developed than the two wingless sisters, and are produced by the same factor-the decrease in surface tension and osmosis. These physiological factors osmosis and surface tension produce the male if they act on the egg at the time of polar-body formation, and the winged viviparous female if they act on the larva within three days after birth. 
In concluding this paper, it may be added here that in the year I909 von Baehr made the following prediction: "Meine Beobachtungen an Schizoneura lanigera führen mich zu dem Schluss, dass der Factor, welcher bei den Embryonen die zu Geschlechtstieren werden, den Impuls zur Ausbildung der Winterovarien und zur Degeneration der schon ziemlich entwickelten parthenogenetische Eiröhren gibt, wahrscheinlich im kausalen Zusummenhang mit der Entwicklung der Flügel, Brustmuskalatur, Sinnesorgane u. s. w. des Muttertieres steht in dem sie sich entwickeln. Derselbe Factor dürfte wohl die Veranlassung sein, dass einige Eier sich zu Männchen entwickeln, wie es im speziellen Teil ausgef ührt wurde, werden nämlich fast immer ausser geschlechtlichen Weibchen noch I-4 Männchen von derselben Mutter geboren."

\section{iX. Aphis Species Mentioned.}

Only the common or vernacular names have been given so far in this paper. It, however, seems necessary to add the scientific names of the aphids I have made use of for the reason that the species of aphids infesting the same host frequently vary with the locality as well as with the season of the year. A list of the specific names, together with some of the more common synonyms, is given below:

I. The small birch aphis:

Caraphis butulaecolens Fitch.

Siphonocallis butulecolens Fitch.

2. The clematis aphis:

Myzus persica Sulz.

Aphis persica.

A. dianthi.

Rhopalosiphum dianthi.

Siphonophora achyrantes.

Myzus malve.

Rhonpalosiphum persica Sulz.

3. The German ivy aphids:

Aphis senecio Swaine (MS.).

4. The California maple aphids:

Thomasia californica Shinji. 
5. The mustard aphis: Aphis brassica Linn.

6. The Periwinkle aphis: Myzus circumflexivum.

7. The green pea aphis:

Macrosiphum ulmarice (Schv.).

Aphis ulmarice Schr.

A. pisi Kalt.

Siphonophora pisi Koch.

S. ulmarice Kalt.

Nectraophora pisi Oestl.

$N$. destructor Johns.

8. The large rose aphis:

Macrosiphum rosa Beaum.

Aphis rose Linn.

A. dipsaci Schr.

Siphonophora rosa Beaum.

Nectarophora rose Linn.

9. The large sonchus aphis:

Macrosiphum solanifolice.

Io. The small sonchus aphis:

Aphis gossipii Glov.

Aphis citrulli Ashm.

A. cucumeris Forbes.

\section{Summary.}

Results of the observations and experiments reported above may briefly be summarized as follows:

I. Either an apterous or an alate parthenogenetic female may bear young larvæ, some of which may finally attain the winged condition, while the others may remain wingless throughout life.

2. When newly born aphids were reared on rose twigs planted in tumblers, containing washed and sterilized sand which had previously been saturated with the solution of a certain substance, nearly one hundred per cent. of winged individuals appeared on the twigs, while either none or few winged forms developed on the twigs charged with any one of another set of chemi- 
cals. For the sake of making a distinction between these two groups of substances, we may call the former the "wing-developing" substances, and the latter, the "non-wing-developing" substances.

3. As far as the tests go, the salts of the alkalis $(\mathrm{Na}, \mathrm{Cl}, \mathrm{K}$, etc.) and alkaline earths ( $\mathrm{Ca}, \mathrm{Br})$ with the exception of magnesium, distilled water, urea, alum and others were shown to belong to the non-wing-developing substances, while the salts of the heavy metals, and of magnesium, sugar, and perhaps some others belong to the category of wing-developing substances.

4. The wing-developing substances were only effective when applied within a certain period after birth. This period varied with temperature and also with the species, $e . g$., the maximum time for the rose aphis, Macrosiphum rosa L., during the early summer was found to be from 2 to 3 days, while under the same conditions from 5 to 7 days was the maximum in the case of the sonchus aphids, Macrosiphum solanifolice Ashm., the mustard aphis, A phis brassica L., etc.

5. The amount of magnesium salts and also of other wingdeveloping substances needed to produce winged aphids was very small. Subjection to a $m / 1$ Ioo solution of magnesium sulphate for I2-24 hours produced nearly one hundred per cent. of winged aphids, so far as Macrosiphum rose was concerned.

6. When twigs planted in the sand saturated with distilled water and calcium chloride were subjected to a drying process, the young aphids born on these twigs remained apterous, whereas on those that had been charged with solutions of magnesium salts or some other wing-developing substances, the greatest number of the winged aphids appeared.

7. When newly born aphids are subjected to a mixed solution of wing-developing and non-wing-developing substances, winged aphids may or may not appear, according to whether or not the solution contains an excess of the wing-developing over the nonwing-developing substances.

8. Variation in temperature, or a sudden change from as high as $100^{\circ} \mathrm{F}$. to as low as $35^{\circ} \mathrm{F}$., failed to produce winged aphids on the twigs charged with non-wing-developing substances. 


\section{Anderson, Stuart}

\section{LITERATURE CITED.}

'9o Nickel and cobalt: their physiological action on the organism. Journ. of Anat. and Physiol., Vol. XVII.

\section{von Baehr, W. S.}

'o9 Die Oögenese bei einigen viviparen Aphiden usw. Arch. Zellf., Vol. III.

Clarke, W. T.

'o3 Wing development in plant lice. Journ. of Tech. U. C. Student Publ., Vol. I., No. 3 .

\section{Ewing, H. E.}

'I6 Eighty-seven generations in a parthenogenetic pure line of Aphis avence Fabr. Biol. Bull., Vol. XXXI., No. 2.

\section{Fischer, M. H.}

'oo On the production and suppression of glycosuria in rabbits through electrolytes. U. C. Publ. Physiol., Vol., I., No. 9.

Herbst, C.

'93 Experinientalle Untersuchungen über den Einfluss der veränderten chemischen Zusammensetzung des umgebenden Mediums auf die Entwickelung der Tiere: I. Versuche an Seeigeleiern. Zeitsch. Wissensch. Zoöl., Vol. LV.

Loeb, J.

'o8 Über den Einfluss von Alkalien und Säuren auf die Embryonale Entwickelung und das Waschstum. Arch. Entwicklungsmec., Vol. VII.. ,

\section{Morgan, T. H.}

'og A biological and cytological study of sex determination in Phylloxera and aphids. Journ. Exper. Zoöl., Vol. VII.

Neiils, J. D.

'I2 Wing production in aphids. Entom. News, Vol. XXIII.

Slingerland, M. V.

'93 Notes from Cornell Insectory, II. Some observations upon plant lice, Vol. XXI.

Tannreuther, Geo. W.

'o7 History of germ cells and early embryology of certain aphids. Zoöl. Jahrb. Abt. Anat. u. Ont., Vol. XXIV.

Woodworth, C. W.

'o8 Winged aphids. Entomol. News, Vol. XIX. 


\title{
EYE-SPOTS IN DIGENEA. ${ }^{1}$
}

\author{
ERNEST CARROLL FAUST, PH.D.,
}

\section{INTRODUCTION.}

While considerable work has been done on the eye structure of the free-living Plathelminthes and ectoparasitic Trematoda, no adequate study of the eye-spots of the digenetic Trematoda has been made. In fact, although the nervous system of this group has been comparatively well known since the days of Lang (I880), students of Trematoda have been content with the mere mention of the occurrence of eye-spots in this or that species, or at most with a description of an isolated case and perhaps a reference to this organ in Turbellaria or ectoparasitic Trematoda.

There remain unanswered, then, two fundamental questions relative to the eyes of Digenea, (I) What is the fundamental structure of this organ, and (2) how extensive is the development of the organ in the group.

\section{- Historical.}

The earliest mention of eye-structure in Digenea was made by O. F. Müller (I773:68, 70) for Cercaria lemna. He suggested that the two black pigment spots of these larvæ were probably eyes. Mehlis (I83I) described for the first time pigment eyes in miracidia (Cathemasia hians). In 1832 von Nordmann (II., I40) made record of the eye-spots in the miracidia of Bunodera lucioperca. Shortly afterward the X-type of pigment pattern in the embryos of Fasciola hepatica and the two beehive spots in the embryos of Cyclocalum mutabile were described. Meanwhile other records of cercariæ with eye-spots had been published. O. F. Müller in 1776 (C. inquieta), Hemprich und Ehrenberg in I83I (C. alata), J. Müller in I850 (C. setifera and C. elegans), and La Valette St. George in I855 (C. ocellata) for cercariæ, and de Filippi in 1857 for the amphistomulum of

${ }^{1}$ Contributions from the Zoölogical Laboratory of the University of Illinois no. II4. 
Diplodiscus subclavatus (Goeze), together with an occasional record of the pigment-spots in miracidia-these observers showed the rather wide distribution of this type of sense organ in the group.

In his second memoir de Filippi (I $857: 433)$ described the pigment spots of Cercaria echinocerca. Among the granules, he wrote, were two large pockets of irregular form but symmetrical arrangement on the sides of the esophagus, comparable to the eyes of the amphistome, while within the pirment pocket was a nucleus which represented a veritable rudimentary lens. Leuckart (I863:465) expressed his credulity about the true lenticular function of the nucleus, but saw the relationship to the eyespots of ectoparasitic trematodes. He mentioned the occasional presence of such organs in the distome, even in the definitive host. Later (I886: 26) he emphasized their homology to the eyes of the Monogenea.

Accounts of the eye structure in ectoparasitic trematodes have been given by Lang (I 880), Goto (I 894), Hesse (I 897), Beers (I90I), and André (I9IO). Lang worked out the histology of this organ carefully for Tristomum coccineum. He found the roots to be a branch of the weak posterior dorsalis, the eye itself to consist of (I) a saucer-shaped pigment cap, (2) a spherical or oval lens, (3) a retinal ganglion cell, and (4) muscle cells. Goto (p. 8I) was unable to believe that the eyes of his species were functional because (I) of the position of the pigment granules between the source of light and the lens and (2) because of the degeneracy in part of the lens itself. He was inclined to consider them as temperature sense organs.

In very young cercariæ of Diplodiscus subclavatus Looss (I892: I65) found two or three limpid cells with refractive nuclei situated on each side of the esophagus. He thought these to be connected with the developing eye-spots, "die oberste vorzugsweise den lichtbrechenden, die unteren vielleicht die percipirenden Apparate darstellen. Alle drei bleiben aber noch einfache Zellen." Osborn (1903), in connection with the histology of Cotylaspis insignis, described eyes for the adults of this species as "located at the front of the pharynx between it and the posterior nerve trunk. . . in close contact with the latter." Each 
eye at its best consisted of a pigment cup in which the contents are figured but not recognized as lenticular in function. Monticelli's study (I9I4) of the eye structure in Cercaria echinocerca Fil. is not as clear as the work of the earlier investigator on this species. The eyes in Cercaria equitator (Ssinitzin, I9I I : Fig. 54) are of interest because they correspond to the X-type originally described for the miracidium of Fasciola hepatica. Cort (I9I5) discussed the eye-spots in monostome and amphistome cercariæ but failed to show their connection with the brain.

\section{MORPHOLOGY.}

The writer has studied intimately the eyes of several monostome and distome cercariæ (Faust, I9I7, I9I8, I9I8a). Of twenty-eight species of cercariæ which have come under the writer's observation, seven possess pigmented eyes and four have non-pigmented eyes. The existence of these non-pigmented eyes was first described by the writer for Cercaria racemosa and C. gracillima (I9I7).

The eye-spots of the binoculate species are usually in direct connection with the posterior dorsal nerve trunks (Faust, I9I8). However, the forked-tailed species, Cercaria gigas (Faust, I9I8a) has connections with the anterior dorsal rami. While the posterior dorsal trunks are, on the whole, much smaller and less important than the corresponding ventral trunks, the ramus to the lateral eye on each side is conspicuous. The cyclopean eye in the trioculate species (confined to certain monostome cercariæ) arises from a fused anterior dorsal nerve trunk. It receives a blunt nerve fiber from below. Thus it differs markedly from the anterior pair of eye-spots in the Monogenea which are innervated by a branch of the same nerve which innervates the posterior pair.

Description of the eye-spot.-In the pigmented eye-spots the pigment consists of a cluster of rather large dark-brown granules, grouped together so as to form a deep cup. At the base of the cup the granules lie several layers deep, but toward the mouth they are seldom more than one layer deep. The opening of the cup in the case of the paired eyes is usually dorsolaterad, whereas the cyclopean eye opens dorsomesad (Fig. I). Within the pigment 
cup is a spherical body, barely touching the pigment granules, opalescent, and containing within it an oval nucleus. This spherical body is the enlarged nerve-cell ending with its nuclues. The nerve may be clearly traced out of the mouth of the pigment cup where it merges into the dorsal branch of the nerve trunk

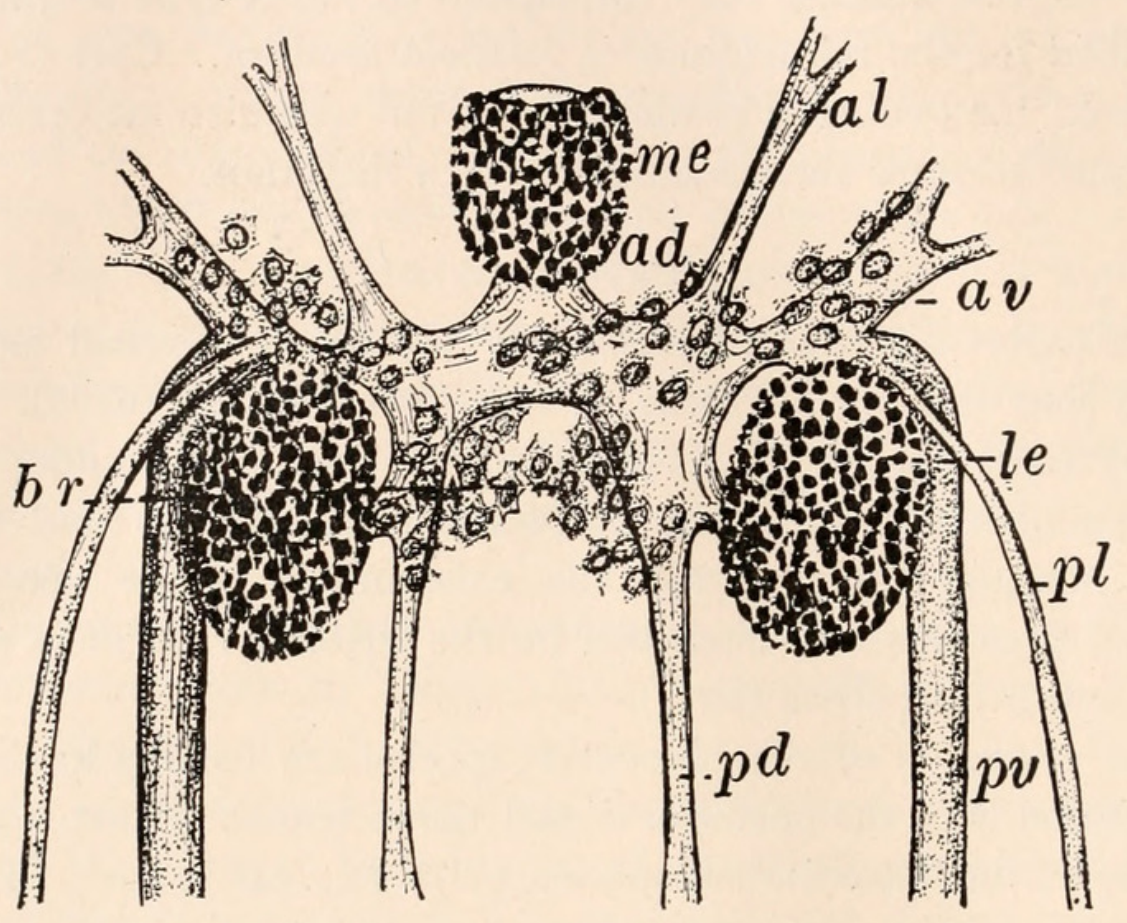

Fig. I. Dorsal view of the central nervous system of Cercaria pellucida Faust, showing paired lateral and cyclopean eye-spots and their connection with the dorsal nerve trunks. $a d$, anterior dorsalis; $a l$, anterior lateralis; $a v$, anterior ventralis; $b r$, ganglion cells; $l e$, lateral eye; $m e$, cyclopean eye; $p d$, posterior dorsalis; $p l$, posterior lateralis; $p v$, posterior ventralis. $\times 660$.

(Fig. 2). Thus the end organ of this nerve is imbedded in the center of the pigment cup. In the mature cercaria the eye-spot is sunken beneath the basement membrane.

The above description holds likewise for the pigmentless eye-spot, except that in this type of organ no pigment is present. It is recognized in the living cercaria as a round milky body slightly whiter and less transparent than the surrounding parenchyma cells. In stained material its nucleus is conspicuous and its connection with the main nerve center can be made out. In Cercaria pellucida although there are ganglion cells scattered superficially along the main nerve trunks no cell is found at the base of the cup. The pigment cup varies in shape from 
saucer-shape to deeply pocketed (C. gigas). In all cases recorded for the Digenea the opening of the cup is toward the source of light. Thus the organ may function as a light-percipient mechanism, although its function is undoubtedly impaired by the position

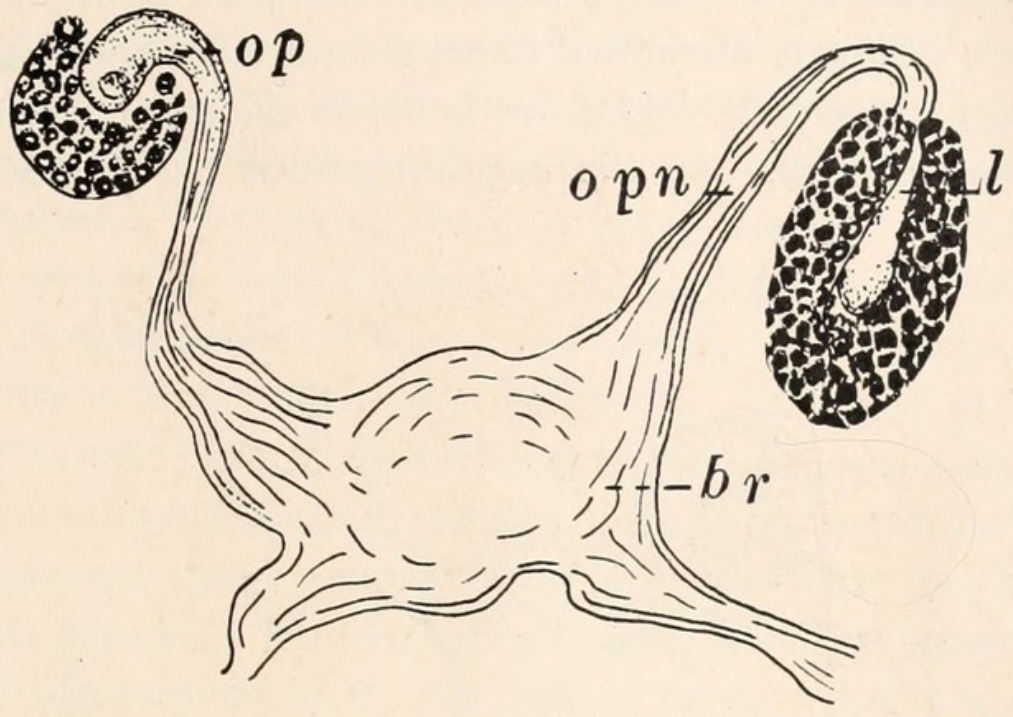

FIG. 2. Section through young Cercaria pellucida showing relation of pigment cup to nerve ending in the paired lateral eyes. $b r$, brain center; $l$, "lens" of authors; $o p$, optic cell; opn, optic nerve. $\times 660$.

of the nerve fiber in front of the "lens." This type of eye-spot shows no differentiation into rod and cone structure, such as André (I9IO) has depicted for Polystomum integerrimum. The mechanism at its best is decidedly an inferior one.

\section{Development.}

The pigment eye-spot of the Digenea, as studied by the writer in Cercaria pellucida Faust, C. urbanensis Cort and C. gigas Faust, presents significant points in development. At an early stage of the germ ball it becomes differentiated in accordance with the precocious development of the nervous system in the group. A branch of the posterior dorsalis, with a single nucleus, pushes out from the nerve center to the dorsolateral margin of the embryo. As it reaches a position near the surface somewhat posterior to the cerebral mass, the ectodermal layer of the embryo pushes inward, just posterior to the nerve, so that a pocket is formed with the opening opposed to the nerve cell. The nerve fiber and enlarged end then twist around the inner wall of the 
pocket so that the bulbous end with its nucleus comes to lie within the cup (Fig. 3). Although the ectodermal cells of this impocketing are at first visible, they appear to play no further part in the development of the organ. Pigment granules are not present until the nerve ending comes to occupy a position within the pocket. Shortly afterward these granules, at first a goldenbrown color, come to be laid down between the nerve ending and the ectodermal cup. As the organ matures the cell with its

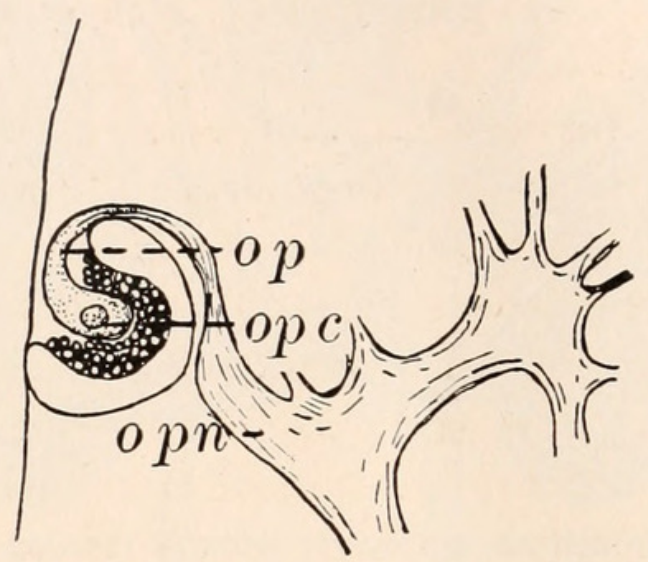

FIG. 3. Section through young germ ball of Cercaria urbanensis Cort, showing formation of pigment granules between optic cup and nerve cell. $o p$, optic cell; $o p c$, optic cell nucleus; opn, optic nerve. $\times 1,460$.

nucleus enlarges and assumes the appearance of a lens, although it does not take on concentric rings. The pigment granules become more numerous and darker in color so that en masse they look black. Meanwhile the ectodermal pocket becomes less and less conspicuous so that in later embryos it entirely disappears.

While the writer can agree with Looss (I892: I65) that a nucleus is concerned with the formation of the "lens," this nucleus is derived from the nerve center rather than from indifferentiated cells in situ. Moreover, the pigment accumulation is not brought about by a secondary nucleus but is the direct result of the apposition of the end organ and the optic cup. Its shape depends on the shape of the optic cup. The melanoidin precipitation is probably a by-product of the nervous system, as has been shown for Cercaria pellucida.

The eye-spots are, then, specialized end organs around which a considerable amount of pigment accumulates on account of 
increased activity. The pigment is possibly both light- and heatpercipient.

\section{Distribution of Pigment in the Digenea.}

For convenience the pigment spots in miracidia, cercariæ, immature and mature trematodes will be discussed separately. Leuckart (I886: 73) states that in general eyes are lacking in miracidia, while Ward (I9I8) defines a miracidium as possessing an eye-spot. In treating the nervous system of Digenea, Braun (I 892) remarks that pigment eyes in adults are exceptional, citing Acanthopsolus ocellatus (Levinsen) as the only adult in this order in which eye-spots are known. A survey of the group shows that the data are isolated and in many cases incomplete.

The common examples usually cited in miracidia are the beehive pigment eyes of Cyclocalum mutabile and the X-type of Fasciola hepatica. Among monostomes it is the common thing to find pigment flecks in the ciliated larva, even in the eggs in utero. Among distomes the only species found with pigmented eyes in miracidia are Fasciola hepatica, F. hepatica var. egyptiaca, Bunodera lucioperce, and Cathemasia hians (fide Leuckart). The miracidium of the holostome, Strigea cornucopice (von Linstow, I885) possesses conspicuous eye-spots. No record of pigment spots in the miracidia of amphistomes has been found, although Looss (I892, I896) has worked out the details in the early stages of the life history of four representative species. The miracidia of the Aspidocotylea are not well known.

No pigment eye-spots have been described for the parthenitæ.

Turning to the cercariæ, one is struck by the disproportionally wide distribution of pigmented eyes. In monostomes the cercariæ thus far described possess eye-spots of the binoculate or trioculate types (Fig. I). Amphistome cercariæ are commonly binoculate. Both monostome and amphistome cercariæ have a considerable amount of pigmentation over the nerve center around the eyes. However, the greatest number of records of eyes in cercariæ concerns the distomes. They are recorded for gymnocephalous species by Ercolani (I 88 I : 54, 55), and Looss (I 896: 204-210); for setiferous species by La Valette (I855), Odhner (I9I4) and de Filippi (I 857:433); for stylet cercariæ by Ssinitzin 
(I9II) and Faust (I9I7); for furcocercous forms by La Valette (I855), Sonsino (I897), Cort (I9I4, I9I7), O’Roke (I9I7) and Faust (I9I7, I9I $8 a)$; and, in addition, for many other less closely related species by O. F. Müller (I773, I776), Hemprich und Ehrenberg (I83I) and Ssinitzin (I9II). Holostome cercariæ have not been shown to possess pigment eye-spots. The existence of the cercaria stage in Aspidocotylea is still uncertain.

After the cercaria stage the pigment may persist for a little while but is usually lost on the arrival of the fluke within the definitive host. However, the pigment granules persist in some cases, being found in the mature worm. Although the pigmentation of the monostome cercaria is carried over to the encysted monostomulum, pigmentation in adult monostomes is quite unknown. On the other hand, several amphistomula which have reached their final host still have a clump of pigment granules around the optic end organ. Among distomes the distomula and adults known to possess pigment eye-spots belong to the Allocreadiidæ or closely related species. In many cases the pigmentation is faint and the "lens" degenerate. No holostome adults are recorded as having pigmented eyes. Whereas the other stages in the life cycle of the Aspidocotylea are in doubt, the group is represented in the adult stage by one pigmented species, Cotylaspis insignis.

Reviewing the entire field of the Digenea, pigment eye-spots are found in representative species of all suborders of the Prostomata at one time or another in the life cycle of the individual. Among the monostomes, both miracidia and cercariæ commonly possess these organs. Amphistome miracidia usually lack pigment eyes, while amphistome cercariæ are usually binoculate. Holostome miracidia are pigmented (at least in one species), while neither cercariæ nor adults are pigmented. Few distome miracidia are marked by pigment eyespots, although a pigmented optic organ is common in cercariæ of various distome families and usually present in Allocreadiide distomula and adults. The only recorded instance of pigmented eye-spots in miracidia, cercariæ, and adults is that of Bunodera lucioperca. 
Table Showing Pigmented Eye-spots in Digenea.

\begin{tabular}{|c|c|c|c|}
\hline Group. & Miracidium. & Cercaria. & Adult. \\
\hline $\begin{array}{l}\text { Gasterostomata ...... } \\
\text { Prostomata }\end{array}$ & none & none & none \\
\hline Aspidocotylea.... & ? & ? & $\begin{array}{l}\text { present in Cotylaspis } \\
\text { insignis }\end{array}$ \\
\hline Monostomata.... & common & common & none \\
\hline Amphistomata .... & none (?) & common & $\begin{array}{l}\text { in amphistomula and } \\
\text { some adults }\end{array}$ \\
\hline $\begin{array}{l}\text { Distomata........ } \\
\text { Holostomata..... }\end{array}$ & $\begin{array}{c}\text { seldom } \\
\text { in Strigea cornucopiae }\end{array}$ & $\begin{array}{l}\text { common } \\
\text { none (?) }\end{array}$ & $\begin{array}{c}\text { in Allocreadiide species } \\
\text { none (?) }\end{array}$ \\
\hline
\end{tabular}

\section{- General Considerations.}

The occurrence of eye-spots in various stages of the life cycle of Digenea and in representative species of all suborders of the Prostomata at one time or another in the life cycle show the fundamental significance of the eye structure. The preservation of the pigmentation and of the "lens" in this or that group has been decidedly erratic and apparently unrelated to the systematology of the group. The great trend has been one of degeneration. If the sporocyst or redia ever possessed eye-spots they have lost all vestiges of them. The absence of eye-spots in many cercaria-trematode generations shuts out any clue of pigmentation at a former period. In some cases absolutely no evidence exists in the life cycle of a possible former pigmentation. In spite of these facts, the widespread pigmentation throughout the Digenea warrants the belief that pigmentation was general throughout the Class at some former time.

In most cases pigment eye-spots have been described because they were conspicuous. It is highly probable that in many species pigmentless eye-spots exist. The three cases on record (Cercaria racemosa, C. gracillima and C. minor) were found only by a most careful study of the worms under high powers of the microscope. While they are undoubtedly functionless, a record of their existence extends the knowledge of the extent of eye-spots and of the types of degeneration that have occurred under conditions of endoparasitism. 
André, J.

\section{IMPORTANT REFERENCES.}

'Io Zur Morphologie des Nervensystems von Polystomum integerrimum Froel. Zeit. wiss. Zool., 95: I9I-220, I3 figs.

Beer, Th.

'or Über primitive Seh-Organe. Wien. klin. Wochensch., I4: 3I4-324.

Braun, M.

'92 Bronn's Tierreich. Vermes. Trematodes. Leipzig. 619 pp., 27 pl.

Cort, W. W.

'I4 Larval Trematodes from North American Fresh-Water Snails. Jour. Parasit., I: $64-84$, I3 figs.

'I5 Some North American Larval Trematodes. Ill. Biol. Monogr., I: 447-532, 8 pl.

' 'I7 Homologies of the Excretory System of the Forked-Tail Cercariæ. Jour. Parasit., 4: 49-57, 2 figs.

de Filippi, Ph.

'57 Deuxième Mémoire pour servir à l'histoire génétique des Trématodes. Mem. r. Acc. Sci. Torino, (2) I6: 4I9-442, 2 pl.

\section{Ercolani, G.}

'8I Dell' adattemento della specie all' ambiente. Nuove ricerche sulla storia genetica dei Trematodi. I. Mem. r. Acc. Ist. Bologna, (4) 3: 46-III; 3 Tav.

Faust, E. C.

'I7 Notes on the Cercariæ of the Bitter Root Valley, Montana. Jour. Parasit., 3: I05-I23, I pl.

'I8 Life History Studies on Montana Trematodes. Ill. Biol. Monogr., 4: II $20,9 \mathrm{pl}$.

'I8a Studies on Illinois Cercariæ. Jour. Parasit., 4: 93-1 Io, 2 pl.

Goto, S.

'94 Studies on the Ectoparasitic Trematodes of Japan. Jour. Coll. Sci. Imp. Univ. Japan, 8 (I): I-273, $27 \mathrm{pl}$.

\section{Hemprich und Ehrenberg.}

'3 I Symbolæ physicæ. Berol. (Cited after Braun.)

Hesse, R.

'97 Untersuchungen über die Organe der Lichtempfindung bei niederen Thieren. II. Die Augen der Plathelminthen. Zeit. wiss. Zool., 62: 527-582, 2 Taf.

Lang, A.

'80 Untersuchungen zur vergleichenden Anatomie und Histologie des Nervensystems der Platyhelminthen. II. Ueber das Nervensystems der Trematoden. Mitth. Zool. Sta. Neapel, 2: 28-56, 3 Taf.

La Valette St. George, A.

'55 Symbolæ ad Trematodum Evolutionis Historiam. Berol. 38 pp. 2 Tab. Leuckart, R.

'63 Die Menschlichen Parasiten. Leipzig u. Heidelberg. 766 pp.

'86 Die Parasiten des Menschen. Leipzig. 897 pp.

Linstow, O. von.

'85 Beobachtungen an bekannten und neuen Nematoden und Trematoden. Arch. Naturgesch., 51: 235-255, 3 Taf. 
Looss, A.

'92 Ueber Amphistomum subclavatum Rud. Leuckart's Festschrift, Leipzig, I 47-I67, 2 Taf.

'96 Recherches sur la Faune parasitaire de l'Égypte. Prem. Partie. Le Caire. Mem. l'institute Egyptien, 3: I-250, I 7 pl.

Mehlis, E.

'3 I Anzeige von Creplin's Novæ Observationes de Entozois. Isis, I83I, pp. I66-I99.

Monticelli, Fr. Sav.

'I4 Ricerche sulla Cercaria setifera di Joh. Müller. Ann. Mus. Univ. Napoli, Müller, J. 4, no. 5. 49 pp., 5 pl.

'50 Ueber eine eigenthümliche Würmlarve aus der Classe der Turbellarien und aus der Familie der Planarien. Arch. Anat. Physiol., I850: 485-500, 2 Taf.

Müller, O. F.

'73 Vermium Terrestrium et Fuviatilium Historia. Havniæ et Lipsiæ. I35 pp.

'76 Zoologiæ Danicæ Prodromus. Havniæ.

Nordmann, A. von.

'32 Mikrographische Beiträge zur Kenntniss der Wirbellosen Thiere, II. Berlin. I50 pp., Io pl.

Odhner, Th.

'I4 Cercaria setifera-von Monticelli- die Larvenform von Lepocreadium album Stoss. Zool. Bid. Uppsala, 3: 247-255, I Taf.

O'Roke, E. C.

'I7 Larval Trematodes from Kansas Fresh-Water Snails. Kan. Univ. Sci. Bull., I0: I6I-I80, 7 pl.

Osborn, H. L.

'o3 On the Habits and Structure of Cotylaspis insignis Leidy, from Lake Chautauqua, New York. Jour. Morph., I 8: I-44, 2 pl.

\section{Sonsino, P.}

'97 Cenni sulle forme larvali di Trematodi osservate nei Gasteropodi di acqua dolce dei diu torni di Pisa. Atti Soc. tosc. Nat. Proc.-verb., I0: 249-253.

Ssinitzin, D. Th.

'i I La génération parthénogénétique des Trématodes et sa descendence dans les mollusques de la Mer Noire. Mém. Acad. Sci. St. Petersbourg, (8) 30, no. 5. $127 \mathrm{pp} ., 6 \mathrm{pl}$.

Ward, H. B.

'I8 Fresh-Water Biology. Parasitic Flat Worms. New York. 98 pp. 



\section{BIOLOGICAL BULLETIN}

\section{THE MARINE BIOLOGICAL LABORATORY}

Twentieth Report; For the Year igi7

\section{Thirtieth Year}

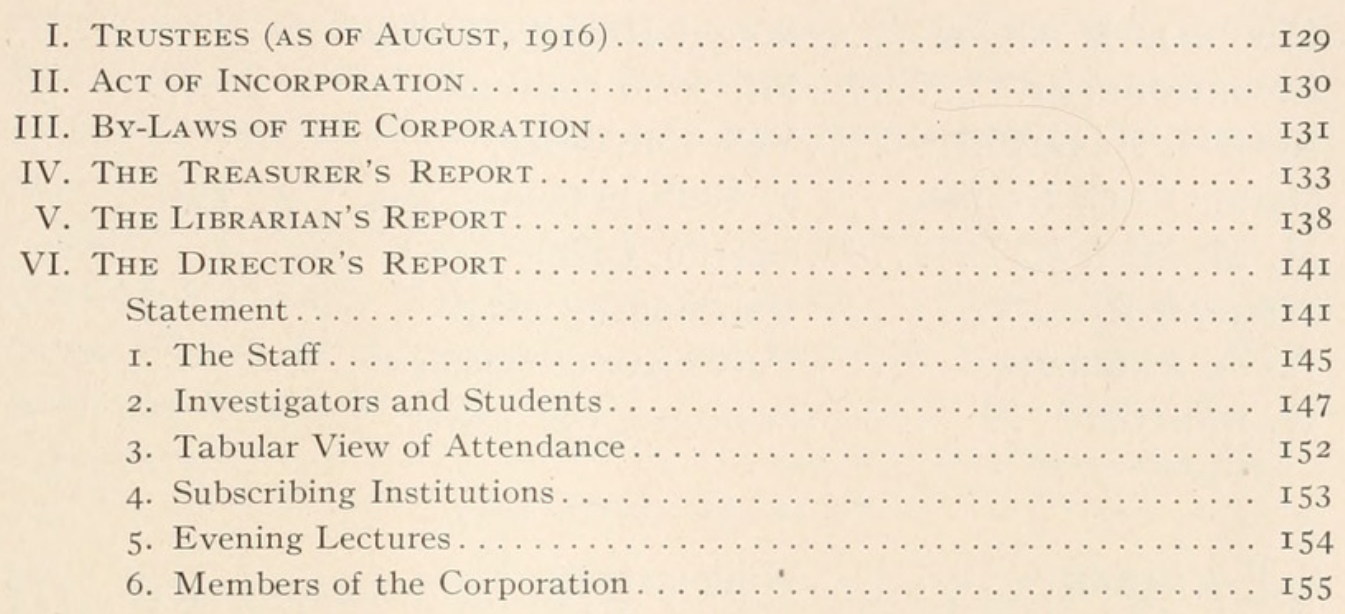

\section{TRUSTEES}

\section{EX OFFICIO}

Frank R. Lillie, Director, The University of Chicago.

Gilman A. Drew, Assistant Director, Marine Biological Laboratory. D. Blakely Hoar, Treasurer, i6 I Devonshire Street, Boston, Mass. Gary N. Calkins, Clerk of the Corporation, Columbia University.

TO SERVE UNTIL I920

H. H. Donaldson........ Wistar Institute of Anatomy and Biology. M. J. Greenman........ Wistar Institute of Anatomy and Biology. C. W. Hargitt . . . . . . . Syracuse University. H. S. Jennings . . . . . . Johns Hopkins University.

George Lefevre....... University of Missouri, Secretary of the

Board.

A. P. Mathews......... The University of Chicago.

G. H. PARker......... Harvard University.

HENRY B. WARD ....... University of Illinois. 
TO SERVE UNTIL I9I9

H. C. Bumpus . ....... Tufts College.

R. A. Harper . . . . . . . Columbia University.

W. A. Locy . . . . . . . . Northwestern University.

Jacques Loeb.......... The Rockefeller Institute for Medical Research.

F. P. Mall. ......... Johns Hopkins University.

George T. Moore....... Missouri Botanical Garden, St. Louis.

L. L. Nunn. . . . . . . . . . Telluride, Colo.

John C. Phillips . . . ..... 299 Berkeley Street, Boston, Mass.

TO SERVE UNTIL I9I 8

Cornelia M. Clapp....... Mount Holyoke College.

E. G. Conklin .......... Princeton University.

Ross G. HARrison . . . . . Y Yale University.

Camillus G. Kidder.....27 William Street, New York City.

M. M. Metcalf . ....... Oberlin, Ohio.

William Patten........ Dartmouth College.

JACOB REIGHARD........ University of Michigan.

W. B. Scotт . . . . . . . Princeton University.

TO SERVE UNTIL I9I 7

S. F. Clarke ........Williamstown, Mass.

Charles A. Coolidge.....Ames Building, Boston, Mass.

C. R. Crane. . . . . . . . Woods Hole, Mass., President of the Board.

Alfred G. Mayer........ Carnegie Institution.

C. E. McClung . . . . . . University of Pennsylvania.

T. H. Morgan.......... Columbia University.

Erwin F. Smith . . . . . . United States Department of Agriculture. E. B. Wilson ......... Columbia University.

\section{ACT OF INCORPORATION}

No. 3170.

\section{Commonwealth of Massachusetts}

Be It Known, That whereas Alpheus Hyatt, William Sanford Stevens, William T. Sedgwick, Edward G. Gardiner, Susan Minns, Charles Sedgwick Minot, Samuel Wells, William G. Farlow, Anna D. Phillips and B. H. Van Vleck have associated themselves with the intention of forming a Corporation under the name of the Marine Biological Laboratory, for the purpose of establishing and maintaining 
a laboratory or station for scientific study and investigation, and a school for instruction in biology and natural history, and have complied with the provisions of the statutes of this Commonwealth in such case made and provided, as appears from the certificate of the President, Treasurer, and Trustees of said Corporation, duly approved by the Commissioner of Corporations, and recorded in this office;

Now, therefore, I, Henry B. Pierce, Secretary of the Commonwealth of Massachusetts, do hereby certify that said A. Hyatt, W. S. Stevens, W. T. Sedgwick, E. G. Gardiner, S. Minns, C. S. Minot, S. Wells, W. G. Farlow; A. D. Phillips, and B. H. Van Vleck, their associates and successors, are legally organized and established as, and are hereby made, an existing Corporation, under the name of the MARINE Biological LABORATORY, with the powers, rights, and privileges, and subject to the limitations, duties, and restrictions, which by law appertain thereto.

Witness my official signature hereunto subscribed, and the seal of the Commonwealth of Massachusetts hereunto affixed, this twentieth day of March, in the year of our Lord One Thousand, Eight HunDRED and EIGHTY-EIGHT.

[SEAL.]

HENRY B. PIERCE, Secretary of the Commonwealth.

\section{BY-LAWS OF THE CORPORATION OF THE MARINE BIOLOGICAL LABORATORY}

I. The annual meeting of the members shall be held on the second Tuesday in August, at the Laboratory, in Woods Hole, Mass., at I2 o'clock noon, in.each year, and at such meeting the members shall choose by ballot a Treasurer and a Clerk, who shall be, ex officio, members of the Board of Trustees, and Trustees as hereinafter provided. At the annual meeting to be held in 1897 , not more than twenty-four Trustees shall be chosen, who shall be divided into four classes, to serve one, two, three, and four years, respectively, and thereafter not more than eight Trustees shall be chosen annually for the term of four years. These officers shall hold their respective offices until others are chosen and qualified in their stead. The Director and Assistant Director, who shall be chosen by the Trustees, shall also be Trustees, ex officio.

II. Special meetings of the members may be called by the Trustees, to be held in Boston or in Woods Hole at such time and place as may be designated. 
III. The Clerk shall give notice of meetings of the members by publication in some daily newspaper published in Boston at least fifteen days before such meeting, and in case of a special meeting the notice shall state the purpose for which it is called.

IV. Twenty-five members shall constitute a quorum at any meeting.

V. The Trustees shall have the control and management of the affairs of the Corporation; they shall present a report of its condition at every annual meeting; they shall elect one of their number President and may choose such other officers and agents as they may think best; they may fix the compensation and define the duties of all the officers and agents; and may remove them, or any of them, except those chosen by the members, at any time; they may fill vacancies occurring in any manner in their own number or in any of the offices. They shall from time to time elect members to the Corporation upon such terms and conditions as they may think best.

VI. Meetings of the Trustees shall be called by the President, or by any two Trustees, and the Secretary shall give notice thereof by written or printed notice sent to each Trustee by mail, postpaid. Seven Trustees shall constitute a quorum for the transaction of business. The Board of Trustees shall have power to choose an Executive Committee from their own number, and to delegate to such Committee such of their own powers as they may deem expedient.

VII. The President shall annually appoint two Trustees, who shall constitute a committee on finance, to examine from time to time the books and accounts of the Treasurer, and to audit his accounts at the close of the year. No investments of the funds of the Corporation shall be made by the Treasurer except approved by the finance committee in writing.

VIII. The consent of every Trustee shall be necessary to dissolution of the Marine Biological Laboratory. In case of dissolution, the property shall be given to the Boston Society of Natural History, or some similar public institution, on such terms as may then be agreed upon.

IX. These By-Laws may be altered at any meeting of the Trustees, provided that the notice of such meeting shall state that an alteration of the By-Laws will be acted upon.

$\mathrm{X}$. Any member in good standing may vote at any meeting, either in person or by proxy duly executed. 


\section{TREASURER'S REPORT}

\section{Marine Biological Laboratory Balance Sheet, DECEMBER 3I, I9I 7}

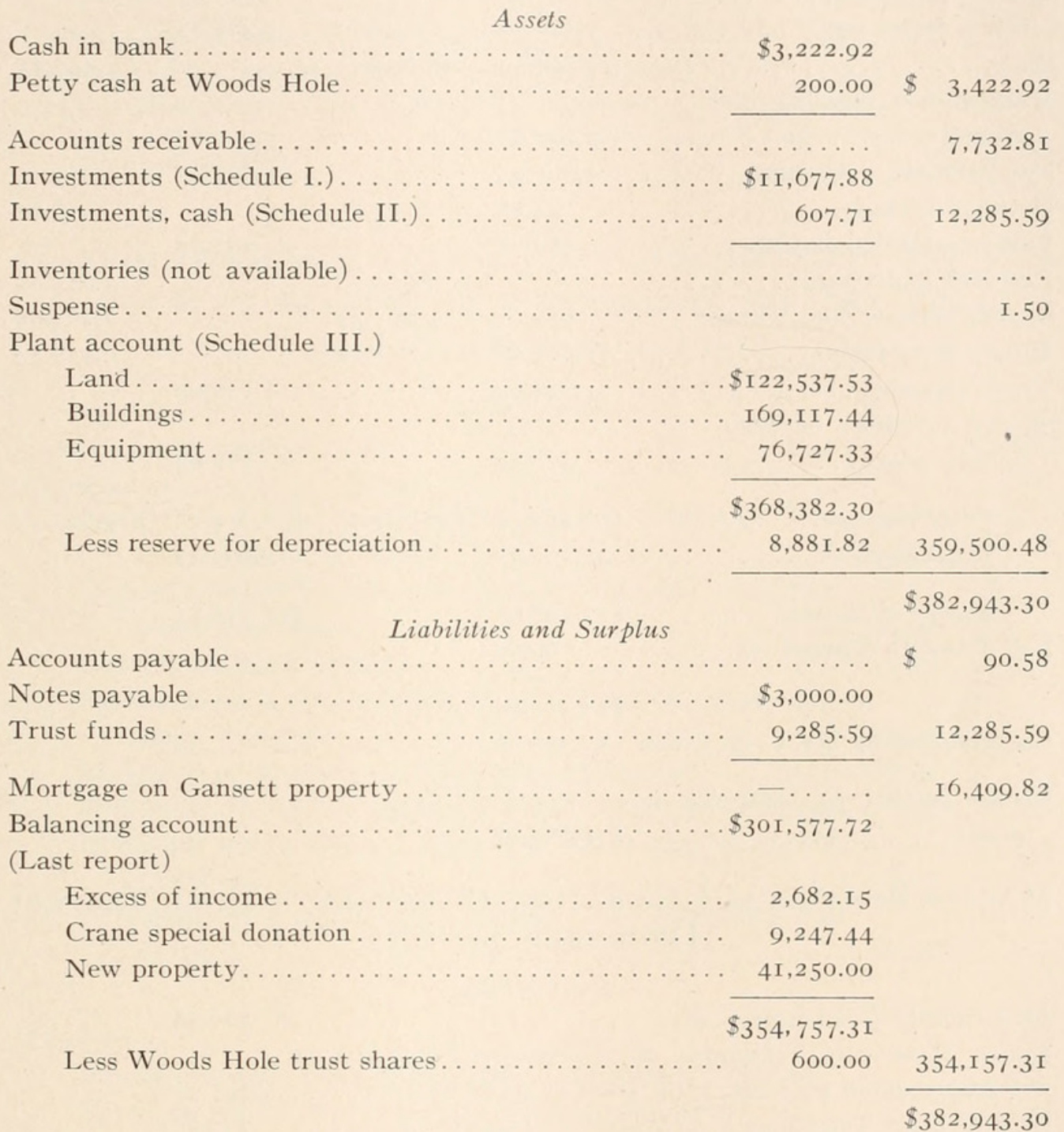

\section{Marine Biological Laboratory Income And Expense for YEAR ENDED DECEMBER 3I, I9I7}

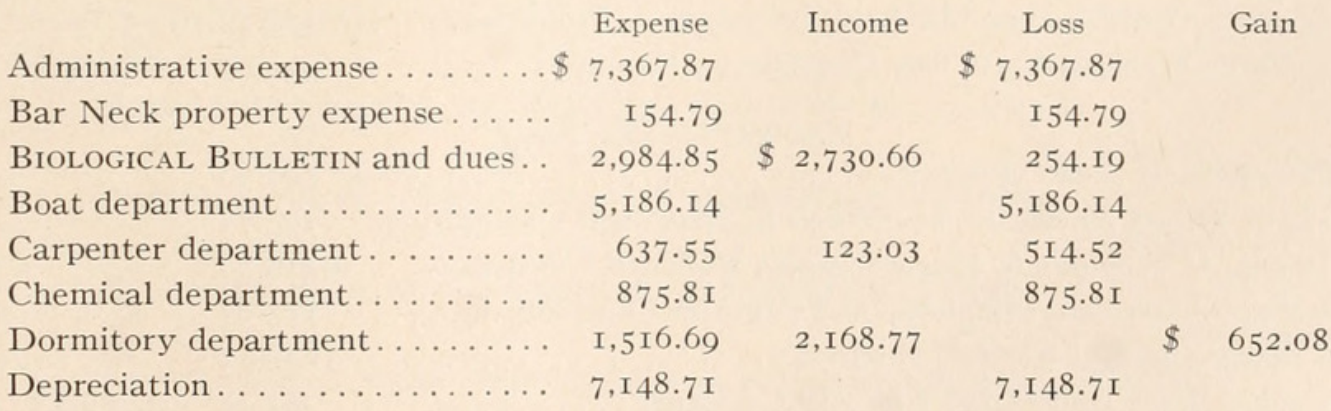


Fish trap.............. 830.04

Gansett property expense...... 939.08

Interest on notes payable..... I 50.00

Instruction . . . . . . . . . . 3,992.09

Lectures, philosophical ........ I00.00

Lectures, evening ........... 65.00

Library department........ 2,503.62

Mess... . . . . . . . . . . . I I,394.20

Maintenance, buildings and

grounds............. 3,222.66

New laboratory expense....... I, 847.40

Newman cottage........... 44.28

Pumping station expense...... 286.75

Research department..........

Sundry expense and income.... 982.8I

Supply department......... I2,002.68

Truck expense............ I, I 48.65

Special dormitory expense

Dexter house........... 372.03

\begin{tabular}{|c|c|c|c|}
\hline & & & \\
\hline Total expense ..........\$69,753.70 & $\$ 52,504.85$ & $\$ 32, \mathrm{I} 12.22$ & $\$ \mathrm{I}_{4}, 863 \cdot 37$ \\
\hline Total income.......... 52,504.85 & & I $4,863 \cdot 37$ & \\
\hline Excess of expense.......\$ ${ }_{17,248.85}$ & & $\$ I 7,248.85$ & \\
\hline
\end{tabular}

Bad accounts charged off....... 69.00

\begin{tabular}{|c|c|c|}
\hline I, 44 I. 77 & & 6 II.73 \\
\hline & 939.08 & \\
\hline & I 50.00 & \\
\hline 4, I30.00 & & I37.9I \\
\hline & I00.00 & \\
\hline & 65.00 & \\
\hline 25.00 & $2,478.62$ & \\
\hline I $6,835.4 \mathrm{I}$ & & I, 44I.2I \\
\hline & $3,222.66$ & \\
\hline & I, 847.40 & \\
\hline I I 2.50 & & 68.22 \\
\hline & 286.75 & \\
\hline $3,675.00$ & & $3,675.00$ \\
\hline $2,447.49$ & & $I, 464.68$ \\
\hline I 8,8 I $_{5} .22$ & & 6,8 I $2 \cdot 54$ \\
\hline
\end{tabular}

I, I 48.65

372.03

$\$ 17,317.85$

Contribution by Mr. C. R. Crane. 20,000.00

Excess carried to balancing ac-

count.............\$2,682.I5

\section{Marine Biological Laboratory Investments (Book Values) December 3i, I9I 7}

\section{Reserve Fund}

$\$ 300$ Liberty Loan Bonds, 4 s................... 300.00

$\$ 3,000$ American Telephone \& Telegraph Company 4s

(represented by receipts for same as collateral) ...... 2,921.25

$\$ 500$ Western Telephone \& Telegraph Company, 5s ..... 496.88

6 shares American Smelting \& Refining Company, Pre-

ferred (receipt on file) ................... 732.00

8 shares General Electric Company ............... 972.05

I4 shares United Shoe Machinery Company, Preferred.... 393.75

5 shares Massachusetts Gas Companies, Preferred....... 444.63

$\$ 6,260.56$

\section{Lucretia Crocker Fund}

$\$$ Ioo Liberty Loan Bond $45 \ldots \ldots \ldots \ldots \ldots \ldots \ldots \ldots \ldots$ 100.00

I/5 of \$I,000 American Telephone \& Telegraph Company 4s I94.75

I8 shares Vermont \& Massachusetts Railroad Company ... 2,4I6.50

I share American Telephone \& Telegraph Company..... I25.03

2 shares General Electric Company............... 240.85

I share West End Street Railway Company.......... 83.00

3, I60.I3 


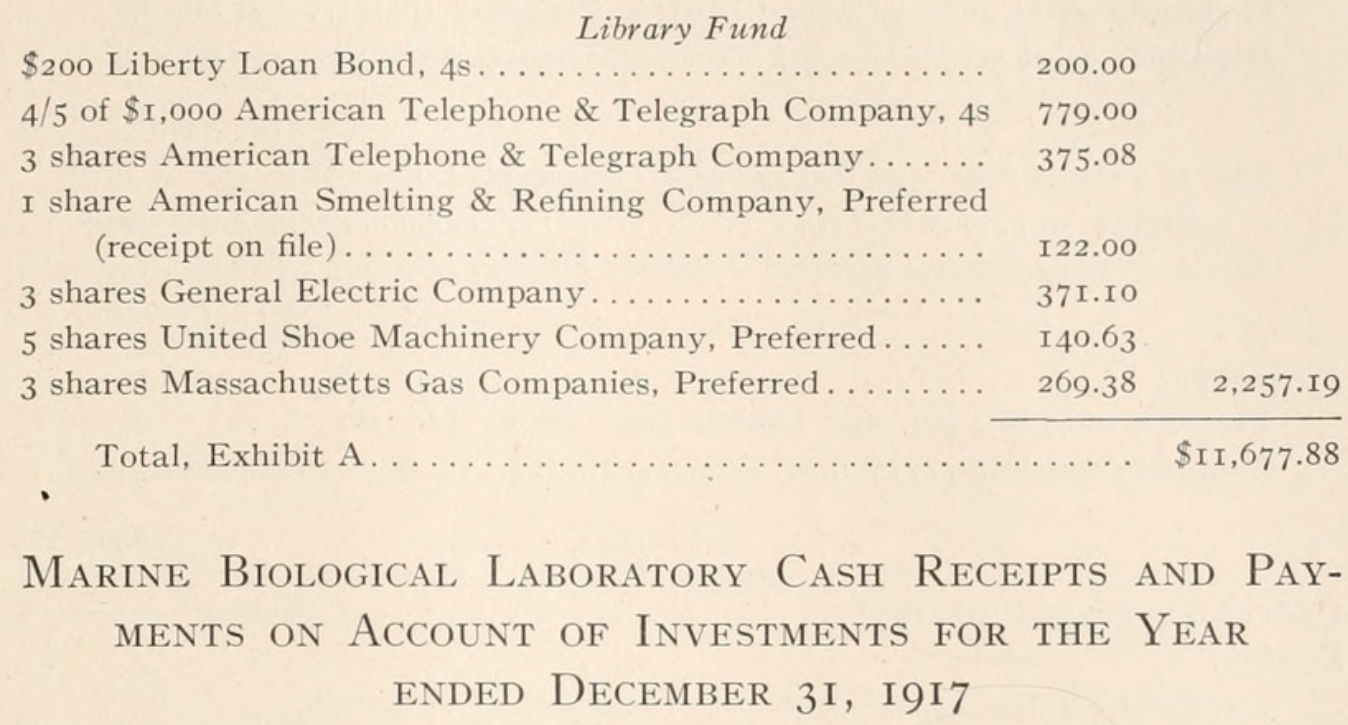

Reserve Fund

Cash on hand January I, I9I7.

$\$ 266.20$

Receipts:

Interest on $\$ 3,000$ American Telephone \& Telegraph Company, 4 per cent. Bonds............... I20.00

Interest on $\$ 500$ Western Telephone \& Telegraph Company,

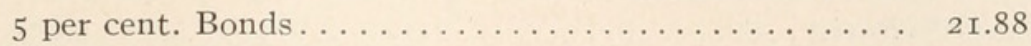

Interest on Bank Balance............... 6.04

Dividends on 6 shares American Smelting \& Refining Company, Preferred.................. 42.00

Dividends on 8 shares General Electric Company ........ 64.00

Dividends on 8 shares General Electric Company Red Cross 8.00

Dividends on 14 shares United Shoe Machinery Company, Preferred . . . . . . . . . . . . . .

Dividends on 5 shares Massachusetts Gas Companies, Preferred . . . . . $20.00 \ldots \ldots \ldots \ldots \ldots \ldots \ldots \ldots \ldots \ldots \ldots$

$2 \mathrm{I} .00$

$\$ 579.12$

Payments:

Purchase of $\$ 3004$ per cent. Liberty Loan Bonds. .\$300.00

Purchase I/4 of $\$ 500$ Western Telephone \& Telegraph Company $5 \mathrm{~s}$.

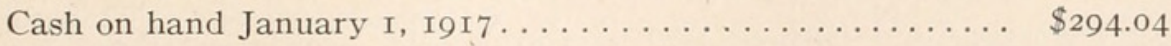

Receipts:

Interest on I/5 of $\$$ I,00o American Telephone \& Telegraph

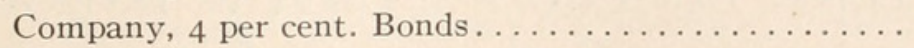

Dividends on 18 shares Vermont \& Massachusetts Railway

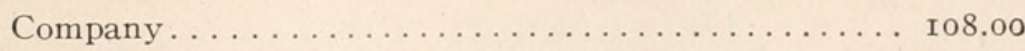

Dividends on I share American Telephone \& Telegraph Company ....................... 8.00

Dividends on I share West End Street Railway Company.. $\quad 3.50$ 
Dividends on $2 \frac{1}{2}$ shares General Electric Company (part). I 7.00

Dividends on $2 \frac{1}{2}$ shares General Electric Company Red Cross $\quad 2.00$

$\$ 440.54$

Sale of I share American Telephone \& Telegraph Company

Rights...................... 2.00

Sale of $\frac{1}{2}$ share General Electric Company Stock........ 83.00

$\$ 525.57$

Payments:

Purchase of \$Ioo 4 per cent. Liberty Loan Bonds. \$Ioo.oo

Paid for Scholarship ............... $50.00 \quad$ I 50.00

\section{Library Fund}

Cash on hand January I, I9I $7 \ldots \ldots \ldots \ldots \ldots \ldots \ldots \ldots \ldots \ldots \ldots \ldots \ldots \ldots$

Receipts:

Interest on $4 / 5$ of $\$$ I, ooo American Telephone \& Telegraph

Company 4 per cent. Bonds............. 32.00

\$50.30

Interest on $\mathrm{I} / 4$ of $\$ 500$ Western Telephone \& Telegraph

Company, 5 per cent. Bonds . . . . . . . . . . . . \$ 3.12

Dividends on 3 shares American Telephone \& Telegraph Co. 24.00

Dividends on I share American Smelting \& Refining Com-

pany Preferred ................... 7.00

Dividends on $2 \frac{1}{2}$ shares General Electric Company (part)... 23.00

Dividends on $2 \frac{1}{2}$ shares General Electric Company Red Cross $\quad 3.00$

Dividends on 5 shares United Shoe Machinery Company

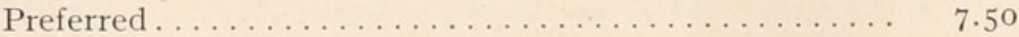

Dividends on 3 shares Massachusetts Gas Companies, Pre-

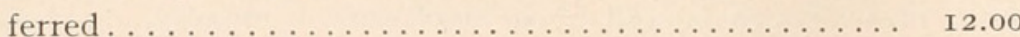

\section{$\$ 229.92$}

Sale of 3 shares American Telephone \& Telegraph Company

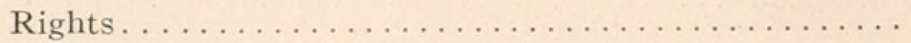

Sale of I/4 of $\$ 500$ Western Telephone and Telegraph Com-

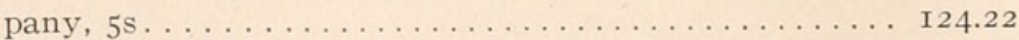

$\$ 360.24$

Payments:

Purchase of \$200 4 per cent. Liberty Loan Bonds. .\$200.00

Purchase of $\frac{1}{2}$ share General Electric Company

Stock. . . . . . . $\ldots \ldots \ldots \ldots \ldots$ 83.00 $283.00 \quad 77.24$

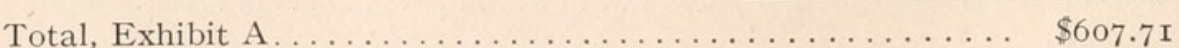

Marine Biological Laboratory Summary of Inventory of Land, Buildings, and Equipment for Period Ended DECEMBER 3I, I9I 7

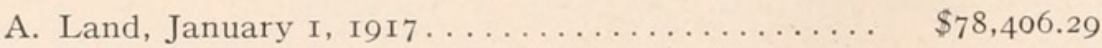

Purchases, I9I 7 -

Bar Neck property . ........\$30,000.00 


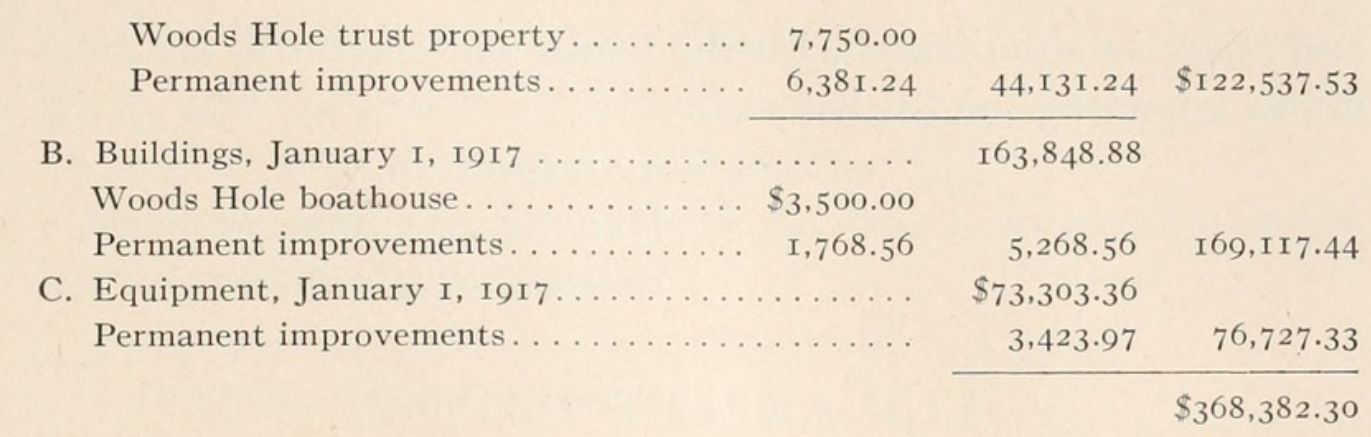

\section{Marine Biological Laboratory Depreciation Reserve}

\section{Buildings}

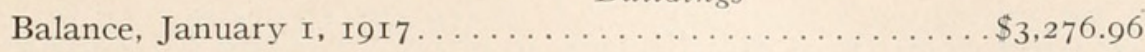

2 per cent. depreciation, I9I $7 \ldots \ldots \ldots \ldots \ldots \ldots \ldots \ldots \ldots \ldots \ldots \ldots \ldots \ldots \ldots .32 .35$

$\$ \$ \$ 6,589.31$

Less upkeep charges. . . . . . . . . . . . . . . . 3,092.05 \$3,497.26

5 per cent. depreciation, I9I 7 .

$\$ 3,665.16$

$3,836.36$

$\$ 7,501.52$

Less upkeep charges

2, I $6.96 \quad 5,384.56$

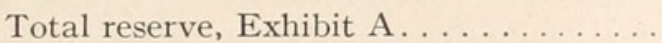

$\$ 8,88$ I. 82

Mr. D. Blakely Hoar,

February 6, I9I8.

i6i Devonshire Street,

Boston.

Dear Sir: We have completed our audit of the accounts of the Marine Biological Laboratory for the year ended December 3I, I9I 7 , as kept both at your office in Boston and at Woods Hole, and report thereon in the accompanying exhibits and schedules:

Exhibit A-Balance-Sheet as of December 3I, I9I7.

B - Income-and-Expense for year ended December 3I, I9I7.

Schedule I-Investments (Book Values).

II-Cash Receipts and Payments on account of Investments.

III-Summary of Inventory of Land, Buildings and Equipment.

IV-Depreciation Reserve.

We certify that, subject to the comments herewith, the balancesheet and income-and-expense statement shown in Exhibits A 
and $\mathrm{B}$ are in accordance with the books and correct to the best of our knowledge and belief.

Very respectfully, Harvey S. Chase \& Co., Certified Public Accountants.

\section{LIBRARIAN'S REPORT}

\section{August I4, I9I7}

The continued growth of the library is shown by the following figures:

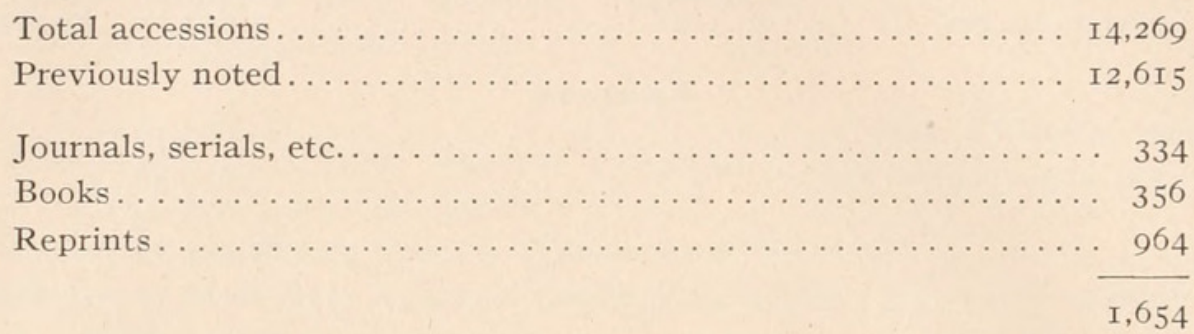

This shows the greatest gain, as compared with last year, in new books and reprints; about four times as many books and one third more reprints. More individuals have demonstrated interest in the library this year. The following must be noted especially:

Books have been received from authors as follows: Raymond Pearl, A. Petrunkevitch, W. E. Castle, James G. Needham, A. M. Reese, W. B. Scott, J. B. Henderson, Jacques Loeb, R. Goldschmidt, H. S. Pratt, A. S. \& P. P. Calvert, A. H. R. Buller and J. E. Peabody.

The University of Chicago Press has given 6 volumes and the Cambridge Press I volume.

Miss Mathilde Koch presented 30 bound volumes and a collection of miscellaneous material, not yet catalogued; Dr. Knower I3 bound volumes and a series of reprints; Prof. S. F. Clarke his collection of papers on hydroids consisting of Io bound volumes and over 300 reprints; Miss Alice W. Wilcox a file of Science and one of the Popular Science Monthly. Dr. W. B. Cannon sent 40 reprints of his own papers and those of his students; and Dr. Wagner two more installments of duplicates 
from the Wisconsin Academy. The Redwood Library, Newport, R. I., sent two boxes of miscellaneous duplicates, from which we have secured several valuable papers.

About 25 volumes and Ioo reprints have been secured by the exchange of duplicate material.

The following sets have been completed this year:

Experiment Station Record,

Proc. Zoöl. Soc. France,

Chemical Abstracts.

The assistant librarian has kept a constant watch for opportunities to secure desirable accessions, as was proposed last year when a special fund requested was set aside for this purpose. The good effects of an extensive preliminary study and correspondence to prepare for such enterprise are now seen. Of the $\$ 500$ set aside for the purchase of second-hand books and periodicals, $\$ 342.60$ has been expended and 25I volumes secured.

Important monographs by Weismann, Garbowski, Blochman and many other bargains were secured; a full set of Wallace and Huxley were added; 33 leather bound volumes of Popular Science Monthly, in perfect condition, were bought at 30 cents each.

89 volumes have been added to incomplete files by securing missing parts. In this way substantial progress has been possible toward making up deficiencies. This method of building in lost parts, now feasible for the first time, is as important as extension From now on desirable bargains are apt to appear in numbers, which will enable us to systematically follow up this campaign. This should be done!

The serials listed below were not on our shelves last year:

Abstracts of Bacteriology,

Journal of Genetics,

Memoirs Zoöl. Soc. France,

Archives Russes d'Anat. d'Hist. et d'Embryol.,

Journ. Russe de Zoölogie, Revue Zoölogique Russe,

Chemical Abstracts.

Journal of Heredity.

The last two journals have been secured by exchange with the Biological Bulletin.

Miscellaneous gifts may be noted as follows: A photograph of 
Professor Whitman, and a medallion of Maupas by Dr. Lillie; a panorama of the Scripps Institute for Biological Research was given by Dr. Ritter, and colored by Miss L. M. Wallace; a history and photographs of the Indiana University Biological Station has been prepared by Dr. Fernandus Payne and presented to the laboratory as part of our biological station exhibit - an excellent idea. Miss Dunn has given a map of Woods Hole in I 887 , just before the establishment of the laboratory.

The Journal Fund and individual financial support, promised from year to year as explained in the report for last year, will be continued. Owing to exceptional conditions we shall not now make any further statement of subscriptions, beyond an acknowledgment to Drs. Just and Alfred G. Mayer for their contributions of \$IO each. The payment of other amounts promised will enable us to continue the New Journal list. Miss Mary E. Collett gave \$IO for the purchase of books on the biography of scientific men.

Two useful undertakings have been started this year: First, a duplication of text-books and monographs which are used in the classes. The extra set will be of great value to investigators. We shall be glad for assistance here. Second, we have extended the loan department, borrowing from and loaning to other libraries, even in the winter, and permitting students here to take out books not demanded by investigators - volumes on the theoretical aspects of the subject, evolution, biography, heredity, etc., have been in demand by a certain few of the students.

As this has been a rather dull year in library development, in as far as external efforts are concerned, it has been possible to do more work in cataloging. Miss Scott has added 5,000 new cards to the author list started in revised form in I9I 3 ; and I 5,O0O subject cards have been made to start a subject-catalogue to be made as complete as possible. It may take 50,000 cards to make this index representative, but the effort seems well worthwhile, especially because of the lapses in foreign bibliographies. Several investigators have gone over the subject scheme and have made valuable suggestions; we are anxious for all the assistance obtainable in this enterprise. 


\title{
VI. THE DIRECTOR'S REPORT
}

\author{
JANUARY I, I9I 8
}

To the Trustees of the Marine Biological Laboratory:

Gentlemen: I beg to present herewith a report of the thirtieth session of the Marine Biological Laboratory covering the year I9I7. Shortly after our country was forced by Germany into a state of war, the suggestion came from several sources that the use of the buildings and equipment of the Marine Biological Laboratory should be offered to the Navy Department for the duration of the war, owing to the evident strategic position of Woods Hole with reference to naval operations. After some consultation the Director decided to write Secretary Daniels offering to recommend to the Board of Trustees that the property and equipment of the Laboratory should be placed at the disposal of the Navy for the duration of the war. It seemed important that the matter should come before the Secretary of the Navy in such a way that he would not fail to recognize the significance of the scientific work that would be displaced. It was therefore arranged through one of our number that the letter should be presented personally to Secretary Daniels by one of the assistant secretaries of the War Department. This was accordingly done. Secretary Daniels returned his thanks for the offer and stated that on account of the importance of the scientific work being accomplished by the men at the Laboratory, he hesitated to accept it, and that the Navy would not take advantage of the offer except under the greatest military necessity, and would not disturb us during the approaching summer.

In the course of the summer it was decided by the Navy Department to subdivide the coast defence work of the Second Naval District with headquarters at Newport among a number of subdistricts or sections and to locate the headquarters of subdistrict A at Woods Hole. H. F. Emmons was placed in command of this section. In the early part of the summer the Director of the Laboratory had several conversations with Commander Emmons which resulted in an agreement to furnish board and lodging to as many members of his corps as was possible up to 
September 15, and to recommend certain arrangements for the winter to our Board of Trustees meeting on August I4. At this meeting the Director reported the negotiations to the Board, which thereupon voted "that the principle underlying the correspondence between Commander Emmons and the Director is approved by the Board of Trustees and that the details regarding use by the Navy of the Laboratory buildings and equipment be referred to the Director and the Assistant Director with power."

In accordance with this vote a contract was drawn up between the Marine Biological Laboratory and the United States of America for the Navy Department, leasing without compensation the mess hall, laundry, kitchen and store house, the homestead, the lecture hall building, the yacht club and the Dexter House together with all necessary equipment from September I5, I9I7, to May I5, I9I8; inventories were attached. It was agreed that there should be compensation for all wear and tear of a damaging character, and that the Navy Department should pay for insurance and all expenses of occupancy. Provision was also made for supervision by the Laboratory of all alterations in buildings, restoration of original conditions as desired, and retention of heating appliances by the Laboratory.

In accordance with this contract the buildings named, with the exception of the Dexter House, which was not needed, are being occupied by the Navy Department.

The spirit of the dealings has been that we should render the greatest possible service to the Navy without prejudice to our work of investigation and instruction. With the expiration of the contract next May the question will arise how to correlate the needs of the Navy with our own demands for the session of I9I8. It is clear that unforeseen circumstances may arise requiring emergency action, and it is therefore suggested that the Board should leave adequate discretion to the Directors for dealing with the situation up to the time of its next meeting.

We are proceeding with the usual arrangements for the next summer session believing that it is the duty of scientific men not called directly to war service to maintain their scientific activities. It was expected that the war would exert an unfavorable effect upon the Laboratory; to a certain extent this expectation has 
been realized, though not to the extent that was anticipated. The total attendance of investigators and students at the Laboratory since I9I3 has been: I9I3, I9I; I9I4, 2I8; I9I5, 242; I9I6, 23I; I9I7, 2I2. If I9I6 is used for reference the reduction in attendance was about 8 per cent., with reference to I9I5 about I $2 \mathrm{I} / 2$ per cent.; only about 3 per cent. less than I9I4, and over Io per cent. more than I9I3. The decline since I9I5 must

- be attributed primarily to war conditions. It must be anticipated that the decline will continue for the duration of the war.

Analyzing the figures of attendance a little farther the attendance of investigators was I29, the same as I9I4 and I9I6, but 8 less than I9I5; the attendance of students was 83 or ig less than in I9I6. Many of the young men, who registered earlier in the year for courses, withdrew on account of military duties; the decrease of attendance of men in courses was I7, of women 2 .

Attendance of Men And Women in Courses

\begin{tabular}{|c|c|c|c|c|c|c|c|c|}
\hline & \multicolumn{2}{|c|}{ I9I7. } & \multicolumn{2}{|c|}{ г916. } & \multicolumn{2}{|c|}{ rgr 5.} & \multicolumn{2}{|c|}{ I9I4. } \\
\hline & Men. & Women. & Men. & Women. & Men. & Women. & Men. & Women. \\
\hline I. Zoölogy .... . . . & 9 & 37 & I 2 & 38 & 20 & 27 & I6 & 27 \\
\hline II. Embryology . . . . . & 6 & IO & I4 & I 2 & I 8 & 19 & IO & I I \\
\hline III. Physiology . . . . . & 6 & 7 & 8 & 6 & I4 & I & 5 & 5 \\
\hline IV. Botany . . . . . . . & 3 & 5 & 7 & 5 & 2 & 4 & IO & 5 \\
\hline Total. . . . . . . & 24 & 59 & $4 \mathrm{I}$ & $6 I$ & 54 & $5 \mathrm{I}$ & $4 \mathrm{I}$ & 48 \\
\hline
\end{tabular}

The number of subscribing institutions was 38 in I9I7 as against 40 in I9I6. The receipts from such institutions were $\$ 4,750$ in I9I 7 as against $\$ 4,900$ in I9I6. The total receipts on account of tuition and investigation were $\$ 7,850$ in I9I $7, \$ 8,625$ in I9I6.

The charge for board at the mess was raised for the first time in thirty years on account of the increased cost of supplies; members of the Laboratory were charged $\$ 5.50$ per week instead of $\$ 5.00$. The rate was raised for those not members of the Laboratory to $\$ 8.00$ per week. Contracts for all staple supplies were made in the winter. The net results were entirely satisfactory to the members and to the Laboratory and the season closed with a net surplus of \$I,44I.2 I, as compared with a loss of \$IOI.52 last year. There will thus be a sufficient sum for 
repairs and replacements for the coming season. Part of the better results for this year must be attributed to the war garden which occupied most of our vacant land and supplied a large quantity of fresh vegetables, and part to a larger percentage of boarders who paid the higher rate and remained later in the season, including members of the Woods Hole Naval Section.

In accordance with the vote of the Board of Trustees on December 29, I9I6, the executive committee adopted regulations with reference to the development of the Gansett property and to sales and leaseholds of parts thereof. Roads have been surveyed through the property and partly built; about I,ooo feet of six-inch water main has been laid; a provisional plan of subdivision of the property into 63 lots has been adopted, prices fixed, and part of it has been accurately surveyed for registration with the land court of Massachusetts, in accordance with the blue print submitted. The sale of five lots to three parties has been negotiated for the sum of $\$ 5,235$. It is also proposed to reserve from sale for the present certain parts of the property for possible construction by the Laboratory of cottages for rent. Mr. Crane has furnished $\$ 5,6$ I 3.56 for this work of development. It is hoped that in the future the receipts from sales and leaseholds will carry the property completely.

In connection with the future development of this property, Mr. Crane has also purchased the Newman lot Ioo $\times 60$ feet with bungalow for the sum of $\$ 2$, ooo and presented it to the Laboratory.

We are farther and most deeply grateful to Mr. Crane for presentation to the Laboratory of the harbor property known as the Bar Neck Wharf, comprising 54,624.4 square feet with 355 feet of harbor frontage. This is a direct continuation of our present frontage on the harbor, and for Laboratory purposes undoubtedly the most valuable piece of real estate in Woods Hole. This property has been conveyed to the Laboratory and was accepted by the Board of Trustees at the summer meeting (I9I7) subject to a lease of forty years to the Bar Neck Corporation, with the provision, however, that they may be dispossessed at any time by vote of our Board of Trustees that the Laboratory requires the use of the property. 
In accordance with the vote of the Board of Trustees last August a committee consisting of H. C. Bumpus, A. P. Mathews and F. R. Lillie has approved a plan for a tablet inscription in Bronze in memory of our first Director and has let the contract to Miss Frances Grimes of New York. It is hoped to place this in the vestibule of our new building before next summer.

Lists of the staff, of investigators and students, a tabular view of attendance, of subscribing institutions, of evening lectures and of members of the corporation are appended as parts of this report.

\section{THE STAFF}

I9I 7

FRANK R. LILLIE, DiRECTOR,

Professor of Embryology, and Chairman of the Department of Zoölogy, The University of Chicago.

Gilman A. DREW, Assistant Director, Marine Biological Laboratory.

\section{ZOÖLOGY}

I. INVESTIGATION

Gary N. Calkins........ Professor of Protozoölogy, Columbia University.

E. G. Conklin ......... Professor of Zoölogy, Princeton University.

Gilman A. Drew ........ Assistant Director, Marine Biological Laboratory.

George Lefevre........ Professor of Zoölogy, The University of Missouri.

Frank R. Lillie.........Professor of Embryology, The University of Chicago.

C. E. McClung .........Professor of Zoölogy, University of Pennsylvania.

T. H. Morgan ......... Professor of Experimental Zoölogy, Columbia University.

E. B. Wilson .......... Professor of Zoölogy, Columbia University.

II. INSTRUCTION

Caswell Grave......... Associate Professor of Zoölogy, Johns Hopkins University.

W. C. Allee .......... Professor of Biology, Lake Forest College. 
Robert Hall Bowen... Graduate Student, Columbia University. W. J. KostiR............ Instructor in Zoölogy and Entomology, Ohio State University.

Francis M. Root.......... Bruce Féllow, Johns Hopkins University. W. H. Taliaferro........Graduate Student, Johns Hopkins University.

Raymond Binford ........ Professor of Zoölogy, Earlham College.

\section{EMBRYOLOGY}

I. INVESTIGATION (See Zoölogy)

II. INSTRUCTION

William E. Kellicott . . Professor of Biology, Goucher College.

Robert A. Budington ... Professor of Zoölogy, Oberlin College.

Charles Packard....... Instructor in Zoölogy, Columbia University.

Charles G. Rogers....... Professor of Zoölogy, Oberlin College.

\section{PHYSIOLOGY}

I. INVESTIGATION

Albert P. Mathews..... Professor of Physiological Chemistry, The University of Chicago.

Ralph S. Lillie........ Professor of Biology, Clark University.

Harold C. Bradley ..... Assistant Professor of Physiological Chemistry, University of Wisconsin.

II. INSTRUCTION

Ralph S. Lillie......... Professor of Biology, Clark University.

Walter E. Garrey....... Professor of Physiology, Tulane University.

Frank P. Knowlton..... Professor of Physiology, Syracuse University.

A. R. Moore........... Professor of Physiology, Rutgers College.

\section{PHILOSOPHICAL ASPECTS OF BIOLOGY AND ALLIED SCIENCES} LECTURES

Edward G. Spaulding.... Professor of Philosophy, Princeton University.

\section{BOTANY}

George T. Moore........ Director, Missouri Botanical Garden and Professor of Botany, Washington University. 
Ivey F. Lewis. . . . . . . Professor of Biology, University of Virginia.

CARL S. HOAR.......... Instructor in charge of Botany, Williams College.

W. D. Hoyt........... Associate Professor of Boilogy, Washington and Lee University.

\section{LIBRARY}

H. McE. Knower. . . . . Professor of Anatomy, University of Cincinnati, Librarian.

MARy E. Scott.......... Assistant Librarian.

\section{CHEMICAL SUPPLIES}

Oliver S. Strong.........Assistant Professor of Neurology, College of Physicians and Surgeons, New York City, Chemist.

\section{SUPPLY DEPARTMENT}

G. M. Gray......... Curator. A. M. Hilton ...... Collector.

John J. Veeder...... Captain. F. G. Gustafson . . Collector in E. M. LEWIS ........ Engineer. Botany.

A. W. Leathers...... Collector. Edna M. Wells.... Clerk.

F. M. MacNaught....... Business Manager.

Herbert A. Hilton...... Superintendent of Buildings and Grounds.

\section{INVESTIGATORS AND STUDENTS}

I9I 7

\section{ZOÖLOGY}

\section{Independent Investigators}

Addison, William H. F., Assistant Professor of Normal Histology and Embryology, University of Pennsylvania.

Allee, Warder C., Professor of Biology, Lake Forest College.

Allen, Ezra, University of Pennsylvania.

Altenburg, Edgar, Instructor in Biology, Rice Institute.

Bigelow, Robert P., Associate Professor of Zoölogy, Massachusetts Institute of Technology.

Binford, Raymond, Professor of Zoölogy, Earlham College.

Bridges, Calvin B., Research Assistant, Carnegie Institution.

Budington, Robert A., Professor of Zoölogy, Oberlin College.

Calkins, Gary N., Professor of Protozoölogy, Columbia University.

Carothers, E. Eleanor, Assistant in Zoölogy, University of Pennsylvania.

Carver, Gail L., Professor of Biology, Mercer University.

Chidester, Floyd E., Professor of Zoölogy, Rutgers College. 
Clapp, Cornelia M., Professor Emeritus, Mount Holyoke College.

Conklin, Edwin G., Professor of Biology, Princeton University.

Copeland, Manton, Professor of Biology, Bowdoin College.

Danchakoff, Mme. Vera, Assistant Professor in Anatomy, Columbia University.

Donaldson, Henry H., Professor of Neurology, Wistar Institute.

Drew, Gilman A., Assistant Director, Marine Biological Laboratory, Woods Hole.

Forbes, William T. M., 23 Trowbridge Road, Worcester, Máss.

Goldfarb, A. J., Assistant Professor of Biology, College of the City of New York. Goldschmidt, RichaRd, Kaiser Wilhelm Institut für Biologie.

Goodrich, Hubert B., Associate Professor of Zoölogy, Wesleyan University.

Gould, Harley N., Assistant Professor, West Virginia University Medical School.

Grave, Caswell, Associate Professor of Zoölogy, Johns Hopkins University.

Gregory, Louise H., Assistant Professor of Zoölogy, Barnard College.

Gross, Alfred O., Assistant Professor of Zoölogy, Bowdoin College.

Hance, Robert T., Assistant in Zoölogy, University of Pennsylvania.

Hogue, Mary J., Instructor in Zoölogy, Wellesley College.

Kellicott, William E., Professor of Biology, Goucher College.

Knower, Henry McE., Professor of Anatomy, University of Cincinnati.

Lillie, Frank R., Chairman Department of Zoölogy, University of Chicago.

McClung, Clarence E., Director of the Zoölogical Laboratory, University of Pennsylvania.

Malone, Edward F., Associate Professor of Antaomy, University of Cincinnati.

Mast, Samuel O., Associate Professor of Zoölogy, Johns Hopkins University.

Metz, Charles W., Staff Member, Carnegie Institution of Washington.

Miner, Roy W., Associate Curator in Invertebrate Zoölogy, American Museum of Natural History.

Morgan, Thomas H., Professor of Experimental Zoölogy, Columbia University.

Muller, Hermann J., Instructor, Rice Institute.

Neal, Herbert V., Professor of Zoölogy, Tufts College.

Osburn, Raymond C., Professor of Zoölogy, Ohio State University.

PACKARD, Charles, Instructor in Zoölogy, Columbia University.

Patten, William, Professor of Biology, Dartmouth College.

Payne, Fernandus, Associate Professor of Zoölogy, Indiana University.

Peebles, Florence, Professor of Biology, Sophie Newcomb Memorial College.

Plough, Harold H., Instructor in Zoölogy, Amherst College.

Rice, Edward L., Professor of Zoölogy, Ohio Wesleyan University.

Richards, A., Professor of Zöology, Wabash College.

Rogers, Charles G., Professor of Comparative Physiology, Oberlin College.

Root, Francis M., Instructor in Zoölogy, Johns Hopkins University.

Smith, Lucy W., Instructor in Zoölogy, Mount Holyoke College.

Spaulding, Edward G., Professor of Philosophy, Princeton University.

Stockard, Charles R., Professor of Anatomy, Cornell University.

Strong, Oliver S., Assistant Professor of Neurology, Columbia University.

Sturtevant, Alfred H., Research Assistant, Columbia University.

Wallace, Edith M., Research Assistant, Columbia University.

Warren, Howard C., Professor of Psychology, Princeton University.

Weinstein, Alexander, Assistant in Zoölogy, Columbia University.

Wieman, Harry L., Head of Dept. of Zoölogy, University of Cincinnati.

Wilson, Charlie W., Head of Biology Department, Mills College. 
Wilson, Edmund B., Professor of Zoölogy, Columbia University.

Woodward, Alvalyn E., Instructor, Simmons College.

Young, Robert T., Professor of Zoölogy, University of North Dakota.

Zeleny, Charles, Professor of Zoölogy, University of Illinois.

\section{Beginning Investigators}

Blake, Irving H., Instructor in Zoölogy, Syracuse University.

Bowen, Robert H., Instructor in Invertebrate Zoölogy, Columbia University.

Brown, Albert M., Columbia University.

Charlton, Harry H., North Billerica, Mass.

Davies, I. J., Technician, Rice Institute.

Fernald, Helen E., Research Assistant, Columbia University.

Gunther, Maude C., Eastern High School, Washington, D. C.

Hayden, Margaret A., 400 West im8th St., New York City.

Hopkins, Hoyt S., Student, Johns Hopkins University.

Kostır, W. J., Instructor in Zoölogy, Ohio State University.

Lynch, Clara J., Brooks Hall, New York City.

Mahr, Ernest F., 227 Clarendon St., Syracuse, N. Y.

Montgomery, Priscilla B., University of Pennsylvania.

Mudd, Stuart, Student, Washington University Medical School.

Olsen, I. E., American Museum of Natural History, New York City.

Parmenter, Charles L., Assistant, University of Pennsylvania.

Safir, Shelley R., Teacher in Stuyvesant High School, New York City.

Shimotori, Show, American Museum of Natural History.

Stark, Mary B., Graduate Student, Columbia University.

StARr, ISAAC, JR., University of Pennsylvania.

Stringer, Caroline E., Head of Department of Natural Science, Omaha High School.

Swingle, Wilbur W., Instructor in Zoölogy, University of Kansas.

Taliaferro, William H., University, Va.

Thiel, George A., Teaching Fellow, University of Minnesota.

\section{PHYSIOLOGY}

\section{Independent Investigators}

Adler, IsaAc, 40r West End Ave., New York City.

Chambers, Robert, Instructor in Anatomy, Cornell University Medical College.

Duesberg, Jules, Research Associate, Carnegie Institution.

Edwards, Dayton J., Instructor in Physiology, College of City of New York.

Garrey, Walter E., Professor of Physiology, Tulane University.

Harvey, E. Newton, Assistant Professor of Physiology, Princeton University.

Harvey, Mrs. E. Newton, Princeton, N. J.

Hoskins, Elmer R., Instructor in Anatomy, New York University.

Hoskins, Mrs. Elmer R., Instructor in Histology, New York University.

Hyde, Ida H., Professor of Physiology, University of Kansas.

Just, ERnest E., Professor of Physiology, Harvard University.

Knowlton, Frank P., Professor of Physiology, Syracuse University.

Lillie, Ralph S., Professor of Biology, Clark University.

Loeb, JAcques, Head of Department of Experimental Biology, Rockefeller Institute for Medical Research.

Lyon, Elias P., Professor of Physiology, University of Minnesota. 
Mathews, A. P., Professor of Physiological Chemistry, University of Chicago. Moore, Arthur R., Professor of Physiology, Rutgers College.

Morgulis, Sergius, Professor of Physiology, Creighton University, College of Medicine.

Northrop, John H., Assistant, Rockefeller Institute for Medical Research.

PARker, George H., Professor of Zoölogy, Harvard University.

Perlzweig, William A., Assistant Professor of Biochemistry, Creighton University, College of Medicine.

Redfield, Alfred C., Teaching Fellow in Physiology, Harvard Medical School. Rudisch, Julius, Consulting Physician, Mount Sinai Hospital, New York.

\section{Beginning Investigators}

Adler, Francis H., Student of Medicine, University of Pennsylvania.

Bright, Elizabetd M., Technician, University of Maine.

Frizzell, Tom P., Fellow in Biology, Rice Institute.

Irwin, Marian, Graduate Student, Radcliffe College.

Moore, Mrs. Arthur R., Graduate Student, Rutgers College.

Young, Elrid G., Demonstrator in Chemistry, McGill University.

\section{BOTANY}

\section{Independent Investigators}

Davis, Bradley M., Professor of Botany, University of Pennsylvania.

Hoar, CARL S., Instructor in Biology, Williams College.

Ноyт, William D., Associate Professor of Biology, Washington and Lee University.

Lewis, Ivey F., Professor of Biology, University of Virginia.

Lyman, George R., Department of Agriculture, Washington, D. C.

Moore, George T., Director, Missouri Botanical Garden, St. Louis.

Osterhout, W. J. V., Professor of Botany, Harvard University.

Stokey, Alma G., Professor of Botany, Mount Holyoke College.

\section{Beginning Investigators}

Furber, JANE M., 769 Washington St., Brookline, Mass.

HaAs, Albert R., Harvard University.

Raber, Oran L., Harvard University.

Stockhausen, Regina E., Assistant in Botany, Mount Holyoke College.

Yampolsky, Cecil, Professor of Biology, Toledo University.

\section{STUDENTS}

I9I 7

\section{BOTANY}

Bishop, Della, Teacher, The Liggett School.

Cleland, Ralph E., Graduate Student, University of Pennsylvania.

Henderson, Margaret W., University of Pennsylvania.

Kinnear, Eunice A., Student, Oberlin College. .

Russell, Alice M., Graduate Student, University of Pennsylvania.

Taylor, William Randolph, Fellow in Botany, University of Pennsylvania.

Thomas, Ruth E., Teacher, East Boston High School, Boston, Mass.

White, Richard P., Student, Dartmouth College. 


\section{EMBRYOLOGY}

Allen, Helen J., Graduate Student, University of Cincinnati.

Armstrong, Nellie P., Student, Knox College.

Bristol, Elisabeth, Vassar College.

Clark, Dana V., Knox College.

Carlson, C. O., Professor of Biology, Doane College.

Dietrich, Bertha K., Teacher, Bushwick High School.

Donovan, Stephen M., Professor of Biology, St. Bonaventure's College.

Gostenhofer, Dorothy M., Student, Columbia University.

HerRICK, Ruth, University of Chicago.

Hinrichs, Marie A., Lake Forest College.

Ingraham, Helen, Student, Knox College.

McKenzie, Robert A., Student, Rutgers College.

Proctor, Harriet T., Student, Radcliffe College.

Stoll, Norman R., Graduate Assistant, University of Michigan.

Warren, Shields, Student, Boston University.

Whiting, Helen B., Instructor in Biology, Brown University.

\section{PHYSIOLOGY}

Ash, Rachel, 4I 76 Leidy Ave., Philadelphia, Pa.

Ashman, Richard, Assistant in Zoölogy, Rutgers College.

Banus, Mario G., Rockefeller Institute.

Beyer, Henry G., U. S. Navy, Retired.

Greenleaf, Walter J., Princeton University.

Griffith, Fred R., JR., Associate Professor of Biology, Southern Methodist University.

Herman, William, Student, Harvard Medical School.

Ingals, Mary G., Student, University of Chicago.

Knight, Mary S., Student, University of Cincinnati.

Littell, Elizabeth D., Head of Science Dept., Brearley School, New York City.

Marks, Pauline C., Radcliffe College.

Stokes, Frances B., Swarthmore College.

Weinstein, Florence, Student, Barnard College.

\section{ZOÖLOGY}

Abt, Arthur F., Student, University of Chicago.

Arnold, Emilie E., Western Reserve Unive*sity.

Bourquin, Helen, Agnes Scott College.

Champlin, Areta L., Student, Mt. Holyoke College.

Clark, Martha L., Student, Doane College.

Coleman, Lawrence V., Assistant in Peabody Museum, Yale University.

Collins, Anna M., Student, Butler College.

Conklin, Mary, Student, Goucher College.

C.rocker, Josephine, Hunter College.

Danforth, Ralph E., East Jaffrey, N. H.

Davy, Mary W., Goucher College.

Elliott, Margaret E., Stucient, Knox College.

Fiske, Mildred, Laboratory Assistant at Wellesley College.

Grbbs, Grace M., University of Maine. 
Graves, Lucy E., Goucher College.

Greenleaf, William E., Graduate Student, Yale University.

Guthrie, Mary J., Assistant in Zoölogy, University of Missouri.

Harper, Isabel W., 36 Mercer St., Princeton, N. J.

Harvey, Lois F., Student, Oberlin College.

Hibbard, Hope, Assistant in Zoölogy, University of Missouri.

Hoagland, Ruth A., Assistant in Zoölogy, Vassar College.

Hosford, Caroline A., Doane College.

Humphreys, Mildred J., Student, Mount Holyoke College.

Jacobs, Helen G., Student, Simmons College.

Kraft, Nettie E. H., Student, Carleton College.

Merritt, Olive E., Hunter College.

Miller, Jeannette, Student, Doane College.

Moore, Emily L., Student, Goucher College.

Nairne, Mathilde A., Student, Sophie Newcomb College.

Nichols, Hope, Student, Mount Holyoke College.

Parker, Mary F., Student, Simmons College.

Pickels, Esther E., Laboratory Assistant, Mount Holyoke College.

Pierce, Ruth W., Student, Oberlin College.

Raymond, Mary, Sophie Newcomb College.

Robbins, Harriet L., Teacher of Biologv, Knox College.

Roenm, Hilda. E., Student, Wellesley College.

Schiller, Esther B., Student, Goucher College.

Seibert, Florence B., Student, Goucher College.

Spong, Philip, Student, Butler College.

Stewart, Dorothy G., Assistant in Department of Zoölogy, Mount Holyoke College.

Stockman, Charles C., 2D, Student, Massachusetts Institute of Technology.

Stone, Leon S., Yale University.

Tappan, Vivian, Student, Barnard College.

Thorndike, Augustus, Jr., Student, Harvard University.

Vrabec, Setti L., Student, Mount Holyoke (ollege.

WiLson, IRA T., Student, Lake Forest University.

\section{TABULAR VIEW OF ATTENDANCE}

\begin{tabular}{|c|c|c|c|c|c|}
\hline & I9I3 & I9I4 & I9I 5 & I9I6 & I9I 7 \\
\hline INVESTIGATORS - Total. & $\mathrm{I} 22$ & 129 & I 37 & I 29 & I 29 \\
\hline \multicolumn{6}{|l|}{ Independent: } \\
\hline Zoölogy . . . . . . . . & $5^{8}$ & 62 & 69 & 70 & 63 \\
\hline Physiology . . . . . . & 17 & 22 & 20 & 23 & \\
\hline Botany . . . . . . . . & . II & IO & 6 & 7 & \\
\hline \multicolumn{6}{|l|}{ Under Instruction: } \\
\hline Zoölogy . . . . . . . & . $2 \mathrm{I}$ & $3 \mathrm{I}$ & 36 & 25 & \\
\hline Physiology ....... & 7 & I & 4 & 3 & \\
\hline Botany......... & 7 & 3 & 2 & I & \\
\hline
\end{tabular}




\begin{tabular}{|c|c|c|c|}
\hline Students-Total.......... 69 & 89 & 105 & $\mathrm{IO} 2$ \\
\hline Zoölogy ............. 33 & 43 & 47 & $5^{\circ}$ \\
\hline Embryology .......... 22 & $2 \mathrm{I}$ & 37 & 26 \\
\hline Physiology . . . . . . . . 8 & IO & I 5 & I 4 \\
\hline Botany ............ 7 & I 5 & 6 & I 2 \\
\hline Total Attendance........... I9I & $2 \mathrm{I} 8$ & 242 & $23 \mathrm{I}$ \\
\hline Institutions RepREsEnted- & & & \\
\hline Total ............ 80 & 77 & 79 & 73 \\
\hline By investigators......... 50 & $5 \mathrm{I}$ & 59 & $5 \mathrm{I}$ \\
\hline By students.......... 4I & 47 & 42 & 45 \\
\hline
\end{tabular}

Schools and Academies Represented.

By investigators........ 3 . 3 I $\quad 3 \quad 004$

By students.......... 6 6 5 5

\section{SUBSCRIBING INSTITUTIONS-I9I7}

Barnard College

Bowdoin College

Carleton College

College of Physicians and Surgeons

Columbia University

Creighton University

Dartmouth College

Doane College

Else Seringhaus Scholarship, Hunter College, New York City

Goucher College

HARVARD UNIVERSITY

Johns Hopkins University

Kaiser Wilhelm Institut für Biologie

Lake Forest College

Lucretia Crocker Scholarship

Mount Holyoke College

Oberlin College

Princeton University, Dept. of Biology

Princeton University, Dept. of Psychology

Radcliffe College

Rice Institute

Rockefeller Institute for Medical Research

Rutgers College 


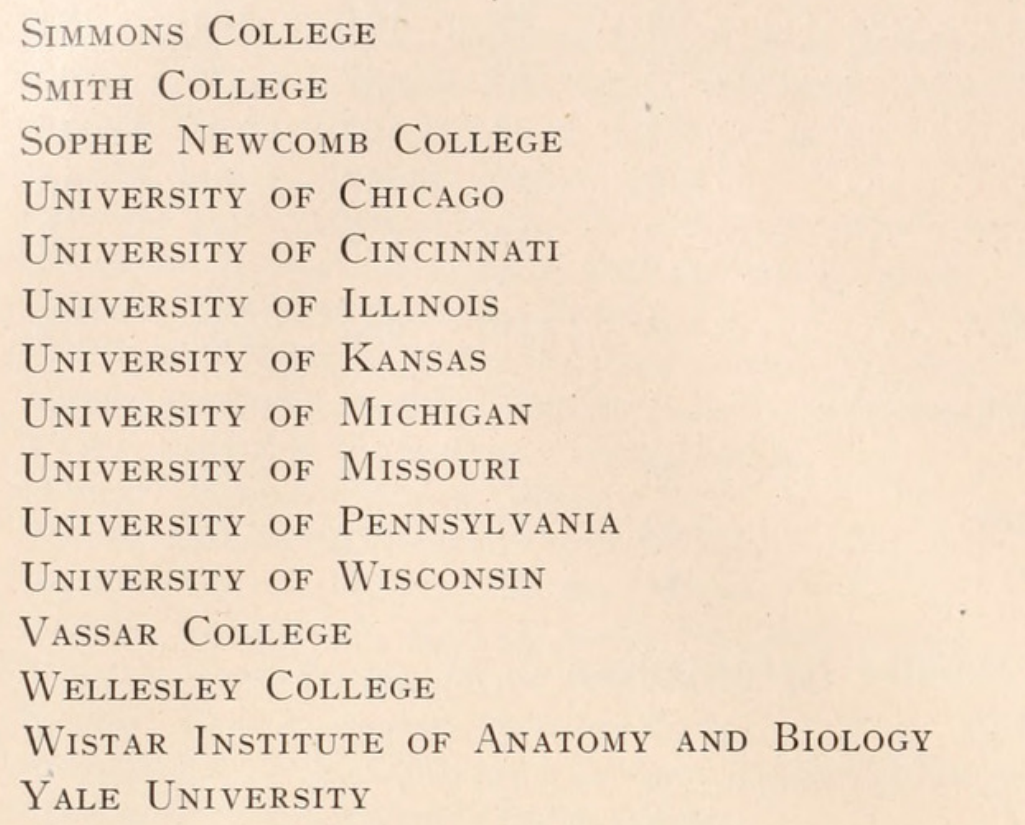

\section{EVENING LECTURES, I9I7}

Tuesday, July 3 ,

Prof. G. H. Parker............ "New Experimental Evidences on the Question of Hearing in Fishes."

Friday, July 6

Prof. T. H. Morgan..........."The Factorial Treatment in Heredity.",

Wednesday, July i I,

Dr. G. H. Clowes............ "Surface Tension and Protoplasmic Permeability."

Friday, July I3,

Prof. William Patten......... "The Creative Power of Co. operation."

Tuesday, July I 7 ,

Dr. Charles R. Stockard...... "Modification of Germ Cells by Alcohol."

Friday, July 20,

Dr. George T. Moore.........."Some Phases of Applied Botany."

Tuesday, July 24,

Dr. Gilman A. Drew.........."The Spermatophore of the Squid."

Friday, July 27 ,

Dr. C. E. McClung..........."Reactions of Cellular Structures to Physical Agents." 
Tuesday, July $3 \mathrm{I}$,

Prof. Howard C. Warren...... "The Investigation of Human

Friday, Aug. 3, Intelligence."

Prof. H. H. Donaldson........ "Post-Natal Growth of the Mammalian Nervous System."

Tuesday, Aug. 7 ,

Dr. H. LANG.............. "Six Years in the Belgian Congo with Remarks on the Natural History and the $\mathrm{Na}$ -

Friday, Aug. Io, tives."

Mr. William Lyman Underwood . "A Strange Story of the North Woods."

\section{MEMBERS OF THE CORPORATION}

\section{August, I9I7}

Авbott, Prof. J. F., Washington University, St. Louis, Mo.

Addison, Dr. W. H. F., University of Pennsylvania Medical School, Philadelphia, Pa.

Allee, Dr. W. C., Lake Forest College, Lake Forest, Ill.

Allen, Prof. Ezra, I25 Thompson Ave., Ardmore, Pa.

Allyn, Miss Harriet M., Hackett Medical College, Canton, China.

Alsburg, Dr. C. S., U. S. Dept. of Agriculture, Washington, D. C.

Baitsell, Dr. George A., Yale University, New Haven, Conn.

Baker, Mrs. L. D., I23 Chiswick Road, Boston, Mass.

Baker, Dr. E. H., I54 W. Randolph St., Chicago, Ill.

Bancroft, Prof. F. W., Aloha Farm, Concord, Cal.

Bardeen, Prof. C. R., University of Wisconsin, Madison, Wis.

Beckwith, Miss Cora J., Vassar College, Poughkeepsie, N. Y.

Behre, Miss Elinor H., Un versity of Chicago, Chicago, Ill.

Beyer, Dr. H. G., Stoneleigh Court, Washington, D. C.

Bigelow, Prof. M. A., Teachers College, Columbia University, New York City.

Bigelow, Prof. R. P., Mass. Institute of Technology, Cambridge, Mass. 
Binford, Dr. RAymond, Earlham College, Richmond, Ind. Blake, Dr. Irving H., Syracuse University, Syracuse, N. Y. Blakeslee, Prof. A. F., Carnegie Station, Cold Spring Harbor, Lond Island.

Boring, Miss Alice M., University of Maine, Orono, Maine. Box, Miss Cora May, University of Cincinnati, Cincinnati, Ohio.

Bradley, Dr. Harold C., University of Wisconsin, Madison, Wis.

Brumfiel, Mr. Daniel M., University of Iowa, Iowa City, Iowa. Buckingham, Miss Edith N., 342 Marlboro St., Boston, Mass. Budington, Prof. R. A., Oberlin College, Oberlin, Ohio.

Bumpus, Dr. H. C., Tufts College, Tufts College, Mass. Byrnes, Dr. Esther F., I93 Jefferson Ave., Brooklyn, N. Y.

Calkins, Prof. Gary N., Columbia University, New York City, N. Y.

Calvert, Prof. Philip P., University of Pennsylvania, Philadelphia, $\mathrm{Pa}$.

Carlson, Prof. A. J., University of Chicago, Chicago, Ill.

Carothers, Miss Eleanor, University of Pennsylvania, Philadelphia, $\mathrm{Pa}$.

Carver, Prof. Gail L., Mercer University, Macon, Ga.

CARY, Dr. L. R., Princeton University, Princeton, N. J.

Casteel, Dr. D. B., University of Texas, Austin, Texas.

Cattell, Prof. J. McKeen, Garrison-on-Hudson, N. Y.

Cattell, Mr. McKeen, Harvard Medical School, Boston, Mass.

Chambers, Dr. Robert, Jr., Cornell University Medical College, New York City, N. Y.

Chester, Prof. Webster, Colby College, Waterville, Maine.

Chidester, Dr. F. E., Rutgers College, New Brunswick, N. J. Child, Prof. C. M., University of Chicago, Chicago, Ill.

Clapp, Prof. Cornelia M., Mount Holyoke College, South Hadley, Mass.

Clark, Dr. E. R., University of Missouri, Columbia, Mo. Coe, Prof. W. R., Yale University, New Haven, Conn. Cohn, Mr. Edwin J., 3I 5 Central Park West, New York City, N. Y. 
Cole, Dr. Leon J., College of Agriculture, Madison, Wis.

Colley, Dr. R. H., Dartmouth College, Hanover, N. H.

Colton, Prof. H. S., Ardmore, Pa.

Coolidge, Mr. C. A., Ames Building, Boston, Mass.

Copeland, Dr. Manton, Bowdoin College, Brunswick, Maine.

Cowdry, Dr. E. V., Johns Hopkins Medical School, Baltimore,

Md.

Crampton, Prof. H. E., Barnard College, Columbia University,

New York City, N. Y.

Crane, Mrs. C. R., Woods Hole, Mass.

Curtis, Prof. W. C., University of Missouri, Columbia, Mo.

Danchakoff, Mme. Vera, College of Physicians and Surgeons,

New York City, N. Y.

Davis, Mr. Donald W., College of William and Mary, Williamsburg, Va.

Davis, Prof. Bradley M., University of Pennsylvania, Philadelphia, Pa.

Derick, Prof. Carrie M., McGill University, Montreal, Canada.

Dexter, Mr. J. S., University of Saskatchewan, Saskatoon, Saskatchewan.

Dodds, Prof. G. S., University of Missouri, Columbia, Mo.

Donaldson, Prof. H. H., Wistar Institute of Anatomy and Biology, Philadelphia, Pa.

Donaldson, Dr. John C., University of Cincinnati, Cincinnati, Ohio.

Drew, Prof. Gilman A., Marine Biological Laboratory, Woods Hole, Mass.

Duggar, Prof. B. M., Missouri Botanical Garden, St. Louis, Mo. Dungay, Dr. Neil S., Carleton College, Northfield, Minn.

Dunn, Dr. Elizabeth, Woods Hole, Mass.

Eaton, Prof. E. H., Hobart College, Geneva, N. Y.

Edwards, Dr. D. J., College of the City of New York, New York City, N. Y.

Eigenmann, Prof. C. H., University of Indiana, Bloomington, Ind.

Ellis, Dr. F. W., Monson, Mass. 
Farnum, Miss Louise W., 43 Hillhouse Ave., New Haven, Conn. Field, Miss Hazel E., Milwaukee Downer College, Milwaukee, Wis.

Field, Prof. Irving, i Autumn St., Worcester, Mass.

Fish, Mr. J. Burton, Boys' High School, Brooklyn, N. Y.

Gage, Prof. S. H., Cornell University, Itahaca, N. Y.

Garrey, Prof. W. E., Tulane University, Richardson Memorial,

New Orleans.

Gee, Prof. Wilson, Emory University, Oxford, Ga.

Gies, Prof. W. J., Columbia Univ. Dept. Physiological Chemistry, New York City, N. Y.

Glaser, Prof. O. C., University of Michigan, Ann Arbor, Mich. Glaser, Dr. R. W., Bussey Institution, Forest Hills, Mass.

Goldfarb, Prof. A. J., College of the City of New York, New

York City.

Goonrich, Mr. H. B., Wesleyan University, Middletown, Conn. Grave, Dr. Caswell, Johns Hopkins University, Baltimore, Md. Gregory, Dr. Louise H., Barnard College, Columbia University, New York City, N. Y.

Gregory, Dr. Emily R., Sweet Briar College, Sweet Briar, Va. Greenman, Dr. M. J., Wistar Institute of Anatomy and Biology, Philadelphia, Pa.

Gross, Miss Beatrix H., 457 Convent Ave., New York City, N. Y.

Gunther, Miss Maude C., Eastern High School, Washington, D. C.

Guyer, Dr. M. F., University of Wisconsin, Madison, Wis.

Hahn, Dr. C. W., 567 West I86th St., New York City, N. Y. Hance, Mr. Robert T., University of Pennsylvania, Philadelphia, Pa.

Hargitt, Dr. C. W., Syracuse University, Syracuse, N. Y.

Harman, Dr. Mary T., Kansas State Agricultural College, Manhattan, Kans.

Harper, Prof. R. A., Columbia University, New York City, N. Y.

Harrison, Mr. A. C., 660 Drexel Bldg., 5th and Chestnut Sts., Philadelphia, $\mathrm{Pa}$. 
Harrison, Prof. Ross G., Yale University, New Haven, Conn. Harvey, Prof. B. C. H., University of Chicago, Chicago, Ill.

Harvey, Dr. E. N., Princeton University, Princeton, N. J.

Harvey, Mrs. E. N., Princeton, N. J.

Haughwont, Mr. F. G., College of Medicine and Surgery, Calle Herran, Manila.

Hayden, Miss Margaret A., 400 West ir8th St., New York City, N. Y.

Heath, Prof. Harold, Stanford University, Calif.

Hegner, Prof. R. W., University of Michigan, Ann Arbor, Mich. Heilbrunn, Mr. L. V., University of Illinois College of Medicine,

Chicago.

Hoar, Mr. D. Blakeley, i6i Devonshire St., Boston, Mass.

Hogue, Dr. Mary J., Wellesley College, Wellesley, Mass.

Hoge, Dr. Mildred A., Univ. of Indiana, Arbutus Apts., Bloomington, Ind.

Holmes, Prof. S. J., University of California, Berkeley, Calif, Hoskins, Mrs. Elmer R., 338 East 26th St., New York City. N. Y.

Hoyt, Dr. William D., Washington and Lee University, Lexington, Va.

Hyde, Dr. IdA H., State University of Kansas, Lawrence, Kans.

Iseley, Prof. W. B., Central College, Fayette, Mo.

Jackson, Prof. C. M., University of Minnesota, Minneapolis, Minn.

Jacobs, Dr. Merkel H., University of Pennsylvania, Philadelphia, Pa.

Jennings, Prof. H. S., Johns Hopkins University, Baltimore, Md.

Jenner, Prof. E. A., Simpson College, Indianola, Iowa.

Jewett, Prof. J. R., Harvard University, Cambridge, Mass.

Jones, Prof. Lynds, Oberlin College, Oberlin, Ohio.

Jordan, Prof. H. E., University of Virginia, Charlottesville, Va. Just, Prof. E. E., Howard University, Washington, D. C.

Kanda, Dr. Sakyo, Physiological Laboratory, Kyushu Imperial University, Fukuoka, Japan. 
Kellicott, Prof. W. E., Goucher College, Baltimore, Md. Kennedy, Dr. Harris, 286 Warren St., Roxbury, Mass.

King, Dr. Helen Dean, Wistar Institute of Anatomy and Biology, Philadelphia, Pa.

Kingsbury, Prof. B. F., Cornell University, Ithaca, N. Y.

Kingsley, Prof. J. S., University of Illinois, Urbana, Ill.

Kirkham, Dr. W. B., Yale University, New Haven, Conn.

Knower, Prof. H. McE., University of Cincinnati, Cincinnati, Ohio.

Knowlton, Prof. F. P., Syracuse University, Syracuse, N. Y.

Kostir, Mr. W. J., Ohio State University, Columbus, Ohio.

Kribs, Dr. Herbert, University of Pennsylvania, Philadelphia, $\mathrm{Pa}$.

Lane, Prof. Henry H., State University of Oklahoma, Norman, Okla.

Lee, Prof. F. S., 437 West 59th St., New York City, N. Y.

Lefevre, Prof. George, University of Missouri, Columbia, Mo. Lewis, Prof. I. F., University of Virginia, Charlottesville, Va. Lewis, Prof. W. H., Johns Hopkins University, Baltimore, Md. Lillie, Prof. Frank R., University of Chicago, Chicago, Ill.

Lillie, Prof. R. S., Clark University, Worcester, Mass.

Linton, Prof. Edwin, Washington and Jefferson College, Washington, $\mathrm{Pa}$.

Loeb, Prof. Jacques, Rockefeller Institute for Medical Research Loeb, Prof. Jacques, Rockefeller Institute for Medical Research, New York City, N. Y.

Loeb, Dr. Leo, Washington University Medical School, St. Louis, Mo.

Lowther, Mrs. Florence DeL., Barnard College, Columbia University, New York City, N. Y.

Lund, Dr. E. J., University of Pennsylvania, Philadelphia, Pa. Luscombe, Mr. W. O., Woods Hole, Mass.

Lyman, Prof. George R., Federal Horticultural Board, Washington, D. C.

Lynch, Miss Clara J., Smith College, Northampton, Mass. Lyon, Dr. E. P., University of Minnesota, Minneapolis, Minn.

MacCallum, Dr. G. A., 98I Madison Ave., New York City, N. Y. 
McClung, Prof. C. E., University of Pennsylvania, Pniladelphia, Pa.

McGill, Dr. Caroline, Leonard Hotel, Butte, Montana.

McGregor, Dr. J. H., Columbia University, New York City, N. Y.

McIndoo, Dr. N. E., Bureau of Entomology, Washington, D. C.

McMurrich, Prof. J. P., University of Toronto, Toronto, Canada.

Macklin, Dr. Charles C., Johns Hopkins University, Baltimore, Md.

Mahr, Mr. Ernest F., University of Chicago, Chicago, Ill.

Mall, Prof. F. P., Johns Hopkins University, Baltimore, Md.

Malone, Dr. E. F., University of Cincinnati, Cincinnati, Ohio.

Martin, Miss Bertha E., Wheaton College, Norton, Mass.

Marquette, Dr. William, Columbia University, New York City, N. Y.

Mathews, Prof. A. P., University of Chicago, Chicago, Ill.

Mayer, Dr. A. G., Maplewood, N. J.

Meigs, Dr. E. B., Dairy Division Experiment Station, Beltsville, $\mathrm{Md}$.

Meigs, Mrs. E. B., I722 H St., N. W., Washington, D. C.

Meltzer, Dr. S. J., I3 West I2 Ist St., New York City, N. Y.

Metcalf, Prof. M. M., I28 Forest St., Oberlin, Ohio.

Miner, Dr. Roy W., American Museum of Natural History, New York City, N. Y.

Minor, Miss Marie L., Women's University Club, New York City, N. Y.

Minoura, Mr. Tadachika, University of Chicago, Chicago, Ill. Mitchell Dr. Philip H., Brown University, Providence, R. I. Moore, Prof. George T., Missouri Botanical Garden, St. Louis, Mo.

Moore, Dr. Carl R., University of Chicago, Chicago, Ill.

Moore, Prof. J. Percy, University of Pennsylvania, Philadelphia, $\mathrm{Pa}$.

Moore, Dr. A. R., Rutgers College, New Brunswick, N. J.

Moore, Miss Dorothea M., 2 I Kirkland St., Cambridge, Mass.

Morgan, Prof. H. A., Agricultural Experiment Station, Knoxville, Tenn. 
Morgan, Dr. Anna H., Mount Holyoke College, South Hadley, Mass.

Morrill, Prof. A. D., Hamilton College, Clinton, N. Y.

Morrill, Dr. C. V., 338 East 26th.St., New York City, N. Y. Murbach, Dr. Louis, Central High School, Detroit, Mich.

Nachtrieb, Prof. Henry F., University of Minnesota, Minneapolis, Minn.

Neal, Prof. H. V., Tufts College, Tufts College, Mass.

Newman, Prof. H. H., University of Chicago, Chicago, Ill.

Nichols, Dr. M. Louise, 322 I Race St., Philadelphia, Pa.

Oliver, Dr. Wade W., Ohio-Miami Medical College, Cincinnati, Ohio.

Osburn, Prof. R. C., Connecticut College, New London, Conn. Osterhout, Prof. W. J. V., Harvard University, Cambridge, Mass.

Packard, Dr. Charles, Columbia University, New York City, N. Y.

Packard, Dr. W. H., Bradley Polytechnic Institute, Peoria, Ill. Painter, Dr. T. S., University of Texas, Austin, Texas.

Pappenheimer, Dr. A. M., Columbia University, New York City, N. Y.

Parker, Prof. G. H., Harvard University, Cambridge, Mass. Paton, Dr. Stewart, Princeton University, Princeton, N. J. Patten, Dr. William, Dartmouth College, Hanover, N. H. Patterson, Prof. J. T:, University of Texas, Austin, Texas. Payne, Prof. F., University of Indiana, Bloomington, Ind.

Pearse, Prof. A. S., University of Wisconsin, Madison, Wis. Peebles, Miss Florence, Sophie Newcomb College, New Orleans, La.

Phillips, Miss Ruth L., Western College, Oxford, Ohio. Pike, Prof. Frank H., 437 West 59th St., New York City, N. Y. Pinney, Miss Mary E., Bryn Mawr College, Bryn Mawr, Pa. Porter, Mrs. M. B., 402 West 3oth St., Austin, Texas.

Prentiss, Miss Henrietta, Normal College, New York City, N. Y.

Price, Dr. Weston A., Research Commission of the National Dental Association, Cleveland, Ohio. 
Rae, Miss Anne M., 34 Jefferson Ave., Brooklyn, N. Y.

Rankin, Prof. W. M., Princeton University, Princeton, N. J.

Rea, Dr. Paul M., Charleston Museum, Charleston, S. C.

Redfield, Dr. Alfred C., Harvard Medical School, Boston, Mass.

Reighard, Prof. JaCob, University of Michigan, Ann Arbor, Mich.

Reinke, Mr. E. E., Vanderbilt University, Nashville, Tenn.

Rice, Prof. Edward L., Ohio Wesleyan University, Delaware, Ohio.

Richards, Dr. A., Wabash College, Crawfordsville, Indiana.

Robbins, Dr. W. J., Alabama Polytechnic Institute, Auburn, Ala.

Robertson, Miss Alice, Wellesley College, Wellesley, Mass.

Robertson, Prof. W. R. B., University of Kansas, Lawrence, Kansas.

Rogers, Prof. Charles G., Oberlin College, Oberlin, Ohio.

Rosenow, Dr. E. C., Mayos Clinics, Rochester, Minn.

Rudisch, Dr. J., Mount Sinai Hospital, New York City, N. Y.

Sands, Miss Adelaide G., 348 N. Main St., Port Chester, N. Y. Sands, Dr. Georgiana, 348 N. Main St., Port Chester, N. Y. Scott, Dr. Ernest L., Columbia University, New York City, N. Y.

Scott, Prof. G. G., College of the City of New York, New York City, N. Y.

Scott, Prof. John W., University of Wyoming, Laramie, Wyo.

Shull, Dr. A. Franklin, University of Michigan, Ann Arbor, Mich.

Shumway, Mr. Waldo, Amherst College, Amherst, Mass.

Smith, Dr. Bertram G., State Normal College, Ypsilanti, Mich.

Snow, Miss Laetitia M., Wellesley College, Wellesley, Mass.

Sollman, Dr. Torald, Western Reserve University, Cleveland, Ohio.

Spaeth, Dr. Reynold A., Yale University, New Haven, Conn. Spaulding, Dr. E. G., Princeton University, Princeton, N. J. Spencer, Dr. H. J., I25 Washington Place, New York City, N. Y. Sprowles, Miss Edith A., 4833 Griscom St., Frankford, Pa. 
Stewart, Miss Mary W., Barnard College, Columb:a University, New York City, N. Y.

Stockard, Prof. C. R., Cornell Univeristy Medical College, New York City, N. Y.

Stokey, Dr. Alma G., Mount Holyoke College, South Hadley, Mass.

Streeter, Dr. George L., Johns Hopkins Medical School, Baltimore, Md.

Strong, Dr. O. S., Columbia University, New York City, N. Y. Strong, Dr. R. M., Vanderbilt University, Nashville, Tenn.

Sturtevant, Dr. Alfred H., 528 West i23d St., New York City, N. Y.

Tashiro, Dr. Shiro, University of Chicago, Chicago, Ill.

Taylor, Miss Katherine A., Cascade, Washington Co., Md.

Tennent, Prof. D. H., Bryn Mawr College, Bryn Mawr, Pa.

Thomas, Dr. Adrian, 2012 Hanover Ave., Richmond, Va.

Thompson, Prof. Caroline B., I95 Weston Road, Wellesley, Mass.

Tinkham, Miss Florence L., 7i Ingersoll Grove, Springfield, Mass.

Tompkins, Miss Elizabeth M., 20i 5 Bedford Avenue, Brooklyn, N. Y.

Treadwell, Prof. A. L., Vassar College, Poughkeepsie, N. Y. Turner, Mr. C. L., Marquette Univ. School of Medicine, Milwaukee, Wis.

Uhlenhuth, Dr. Edward, Rockefeller Institute for Med:cal Research, New York City, N. Y.

Van Cleave, Dr. H. J., University of Illinois, Urbana, Ill.

Vaughan, Dr. T. W., U. S. Geological Survey, Washington, D. C.

Waite, Prof. F. C., Western Reserve University Medical School, Cleveland, Ohio.

Wallace, Prof. Louise B., Mount Holyoke College, South Hadley, Mass.

Warbasse, Mrs. J. P., 384 Washington Ave., Brooklyn, N. Y.

Ward, Prof. H. B., University of Illinois, Urbana, Ill. 
Wardwell, Dr. E. H., Mattapoisett, Mass.

Warren, Prof. Howard C., Princeton University, Princeton, N. J.

Wasteneys, Dr. Hardolph, University of California, Berkeley, Calif.

Watson, Mr. Frank E., Hobart College, Geneva, N. Y.

Wenrich, Dr. D. H., University of Pennsylvania, Philadelphia, $\mathrm{Pa}$.

Werber, Dr. E. I., Yale University, New Haven, Conn.

Wheeler, Prof. W. M., Bussey Institution, Forest Hills, Mass.

Wherry, Dr. W. B., Cincinnati Hospital, Cincinnati, Ohio.

White, Miss E. Grace, io7o7 Grantwood Ave., Cleveland, Ohio. Whitney, Dr. David D., University of Nebraska, Lincoln, Neb.

Wieman, Prof. H. L., University of Cincinnati, Cincinnati, Ohio.

Wilcox, Dr. Alice W., Fairbanks Museum of Natural History, St. Johnsbury, Vt.

Wildman, Dr. E. E., 47th \& Walnut Sts., Philadelphia, Pa.

Williams, Dr. Anna W., 549 River:ide Drive, New York City, N. Y.

Wilson, Prof. H. V., University of North Carolina, Chapel Hill, N. C.

Woglom, Dr. William H., Columbia University, New York City, N. Y.

Woodruff, Prof. L. L., Yale University, New Haven, Conn.

Woodward, Miss Alvalyn E., Simmons College, Boston, Mass. Whiting, Mr. Phineas W., University of Pennsylvania, Philadelphia, Pa.

Young, Mr. D. B., 33 Dunmoreland St., Springfield, Mass.

.Young, Prof. Robert T., University of North Dakota, University, N. D. 


\section{A STUDY OF SOMATIC CHROMOSOMES.}

\section{The Chromosomes In Embryos of Epilachna borealis AND Diabrotica vittata.}

W. E. HOY, JR.,

Princeton University and the University of Rochester.

Epilachna borealis.

The oögenesis of Epilachna has not been described. Miss Stevens ('o6) briefly described the spermatogenesis of this beetle. There are 18 chromosomes in the spermatogonia. One of these chromosomes, the $y$, is extremely small, its mate, the $x$, is larger. In each plate there are 2 chromosomes noticeably larger than the others. In the first maturation division the $x$-chromosome passes undivided to one pole of the spindle, while the $y$ passes to the other pole. The spermatozoa, then, differ in that one half contain a small $y$, and the other half a larger $x$. Each contains one large macrochromosome (autosome).

Although the oögonial divisions and the maturation of the egg have not been worked out, the anticipated result of fertilization would be two sorts of embryos with respect to their chromosome content, one with two $x$ 's, and one with an $x y$ combination. This expectation is fulfilled in the divisions of the embryonic cells, as I shall show. The stages of development studied were: (I) Late cleavage, and (2) shortening of the elongate embryo. In all about 60 plates have been recorded.

Figs. $\mathrm{I}-4$ are from embryos having the $x y$ combination in their chromosome complexes, these being the smallest chromosomes in the plate. Fig. I is a late cleavage division figure and shows the same characteristic elongation of the chromosomes as was seen in the case of Anasa at a similar stage of development (Hoy, 'I6). Figs. 2 and 3 are from cerebral neuroblasts, and are both from the same individual. Fig. 4 is from an ectoderm cell in the thoracic region. It will be seen that in all these figures there are two macrochromosomes comparable to those 
found in the spermatogonia. Again, in all the figures the small $y$-chromosome is very conspicuous. The $x$-chromosome is here undoubtedly the next smallest in size, since this chromosome has no homologous mate. All the chromosomes show the typical elongate and more or less slender form characteristic of the Coleoptera. There do not seem to be any special peculiarities shown by the seven pairs of mesochromosomes, ranging between the macrochromosome pair and the $x y$ pair, other than that they fall into a graded series according to size.

Plates from embryos containing no very small $y$-chromosome, but apparently having the small $x$-chromosome paired, are shown in Figs. 5-8. All these figures again show the large pair of macrochromosomes, and a series of seven paired mesochromosomes graudally diminishing in size. In none of the figures is there a small rounded $y$-chromosome, but in its place there is another the size of the $x$-chromosome.

It has, therefore, been possible to demonstrate that in Epilachna, where the male has an $x-y$ pair in the spermatogonial complex, the embryos fall into two classes as regards their chromosome content, one class containing an $x y$ pair, and the other $2 x$ 's.

RECORD OF COUnts of Chromosomes in Epilachna.

Stage I.

Cleavage Mitoses. xy Type.

Embryo.
I
2
3
4
5
6

No. of Chromosomes.

No. of Counts.

I8
I8
I
I8
I8
I 8

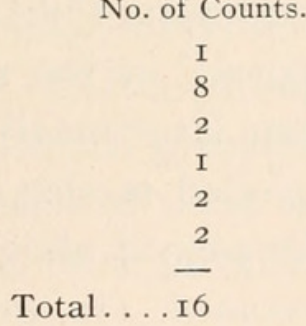

Cleavage Mitoses. $2 x$ Type.

Embryo.
I
2
3
4
5
6

No. of Chromosomes.

No. of Counts.

$\begin{array}{lr}\text { I8 } & \text { I } \\ \text { I8 } & 2 \\ \text { I8 } & \text { I } \\ \text { I8 } & \text { I } \\ \text { I8 } & \text { I } \\ \text { I8 } & 3 \\ & \\ & \text { Total . . }\end{array}$


StAGE II.

Shortening of the Elongate Embryo, xy type.

\begin{tabular}{|c|c|c|c|c|c|c|}
\hline Embryo. & $\begin{array}{c}\text { No. of } \\
\text { Chromo- } \\
\text { somes in } \\
\text { Hypodermis. }\end{array}$ & No. of Counts. & $\begin{array}{l}\text { No. of } \\
\text { Chromo- } \\
\text { somes in } \\
\text { Neuroblast. }\end{array}$ & No. of Counts. & $\begin{array}{l}\text { No. of } \\
\text { Chromo- } \\
\text { somes in } \\
\text { Mesoderm. }\end{array}$ & No. of Counts. \\
\hline \multirow{10}{*}{$\begin{array}{r}\text { I } \\
2 \\
3 \\
4 \\
5 \\
6 \\
7 \\
8 \\
9 \\
\text { I0 }\end{array}$} & I 8 & I & & & & \\
\hline & & & & & I 8 & I \\
\hline & & & I 8 & I & & \\
\hline & & & I 8 & I & & \\
\hline & 18 & 1 & I8 & 3 & & \\
\hline & I 8 & 2 & & & & \\
\hline & & & I 8 & 2 & & \\
\hline & & & I 8 & I & & \\
\hline & & & I 8 & 2 & & \\
\hline & & Total 4 & & Total Io & & Total I \\
\hline
\end{tabular}

$2 x$ Type.

\begin{tabular}{r|c|c|c|c|c|c}
\hline I & I8 & 3 & & & & \\
2 & I8 & I & & & I8 & I \\
3 & & & I8 & I & I8 & I \\
4 & & & & & I8 & \\
5 & I8 & I & & & I8 & I \\
6 & & & & & \\
7 & & & I8 & I & & \\
8 & & & I8 & I & & \\
9 & & I8 & 3 & & \\
I0 & & & I8 & I & \\
\hline
\end{tabular}

Diabrotica vittata.

Miss Stevens ('08) reports 2I chromosomes "of various sizes and shapes" in the spermatogonia of this species. Her figure shows one large macrochromosome pair. If arranged in a paired series graded in size, the unpaired $x$-chromosome would apparently be placed about ninth, followed by two pairs of smaller chromosomes. In the first maturation division the $x$-chromosome moves undivided to one pole of the spindle, giving them two classes of secondary spermatocytes. Of the resulting spermatozoa, one half contain an $x$-chromosome, and one half do not.

The second maturation of the egg was reported in a paper preliminary to this (Hoy, 'I4). Eleven chromosomes enter the female pronucleus. Fig. I 2 shows the chromosomes of the first maturation division. There are eleven, each of them appearing 
as a tetrad. They are clearly of different sizes, though the same size differences, such as appear in the spermatogonia, can not be observed.

Accordingly, two classes of embryos would be expected as the result of the fertilization, one containing $2 \mathrm{I}$, and the other 22 chromosomes in the embryonic cells. These differences have been observed and are shown in Figs. 9-II.

Figs. 9 and Io are of the $2 \mathrm{I}$ chromosome type and are from the same embryo, corresponding in development to the stage of 3 of Epilachna. Fig. I I is from an ectoderm cell of a late blastoderm stage of the 22 chromosome type. In all these figures one pair of chromosomes is much larger than any of the others. With the exception of the ninth chromosome in Figs. 9 and Io, all the other chromosomes form a paired series graded in size. In Fig. I I there is no unpaired chromosome.

\section{Conclusions.}

I. The developing eggs and embryos of Epilachna borealis fall into two classes in respect to their chromatin content, one containing an $x y$ combination, and the other an $x x$ combination of sex chromosomes in all the cells of the body which have been examined, the former corresponding to the chromosomes of the spermatogonia, the latter probably to those of the oögonia. The same size relations are maintained in all the chromosome groups of one type.

2. Two types of chromosome groups are found in embryos of Diabrotica vittata, one with $2 \mathrm{I}$ chromosomes, corresponding to the spermatogonial chromosomes and one with 22, presumably homologous with those of the oögonia. In each of these types the chromosomes do not vary in number and form in different tissue cells which have been studied.

Hoy, W. E., Jr.

BIBLIOGRAPHY.

'I4 A Preliminary Account of the Chromosomes in the Embryos of Anasa tristis and Diabrotica vittata. Biol. Bull., Vol. 27, No. I.

'i6 A Study of Somatic Chromosomes, I. Biol. Bull., Vol. 31, No. 5.

Stevens, N. M.

'o6 Studies in Spermatogenesis. Pub. Carn. Inst. Wash., 36.

'o8 The Chromosomes in Diabrotica vittata, Diabrotica soror and Diabrotica I 2-punctata. Journ. Exp. Zoöl., Vol. 5, No. 4. 
Explanation of Plate I.

Epilachna xy Type.

FIG. I. Cleavage.

FIG. 2. Neuroblast.

FIG. 3. Neuroblast.

FIG. 4. Ectoderm. 


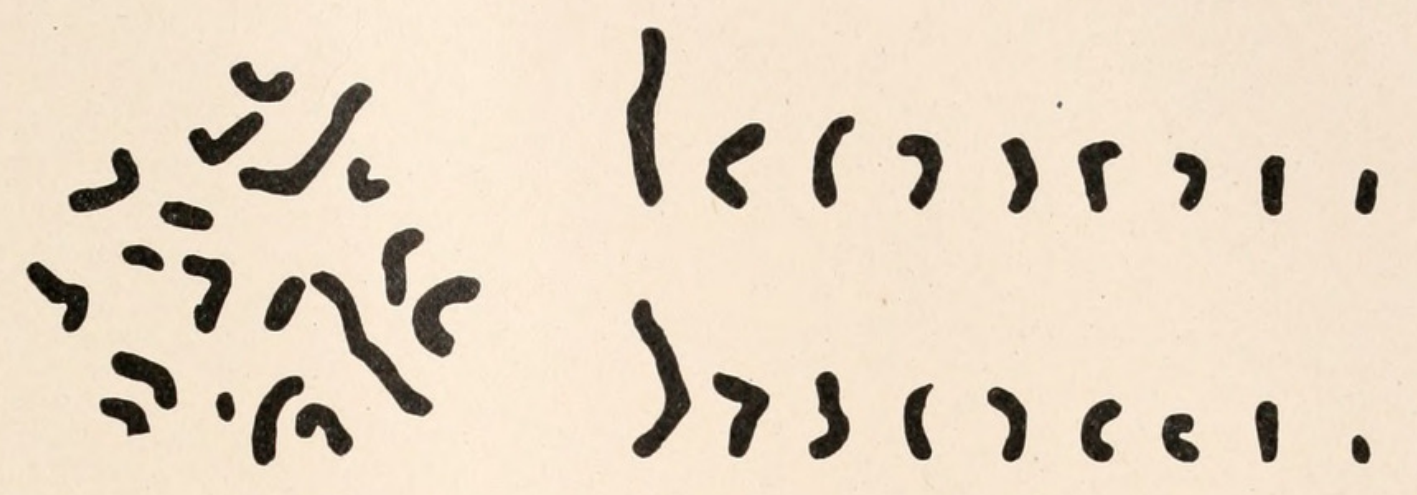

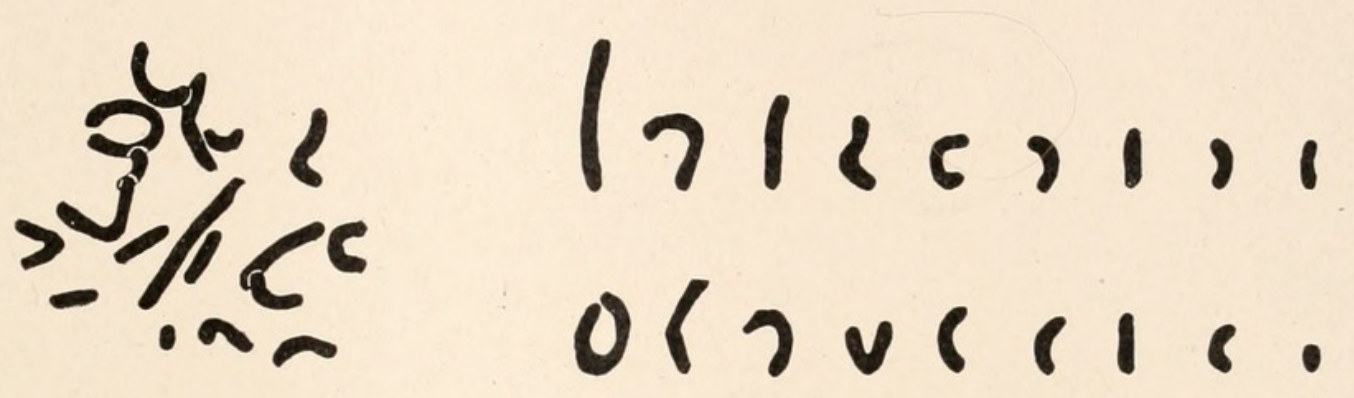

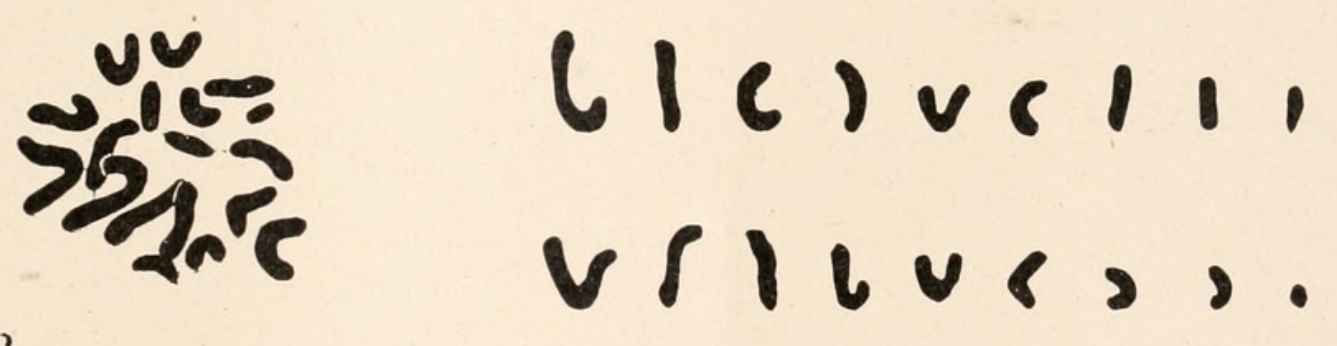

(1), ,

ril ral, 


Explanation of Plate II.

Epilachna xx Type.

FIG. 5. Cleavage.

FIG. 6. Neuroblast.

FIG. 7. Neuroblast.

FIG. 8. Ectoderm. 
J)eberin Jomeser.

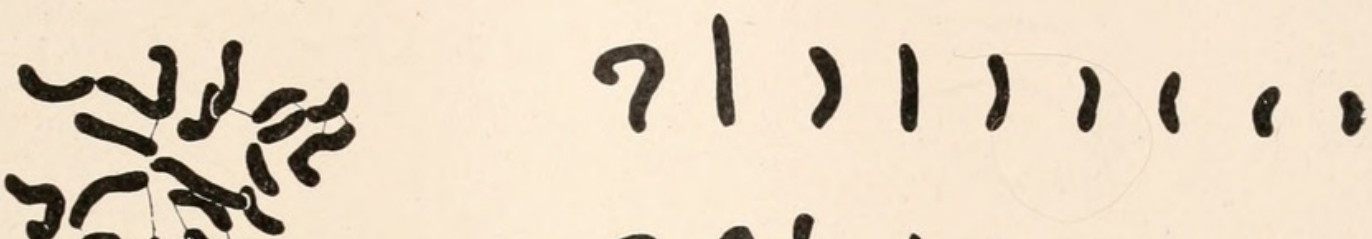
selesere

J $1,1,1)$

c(sesil)

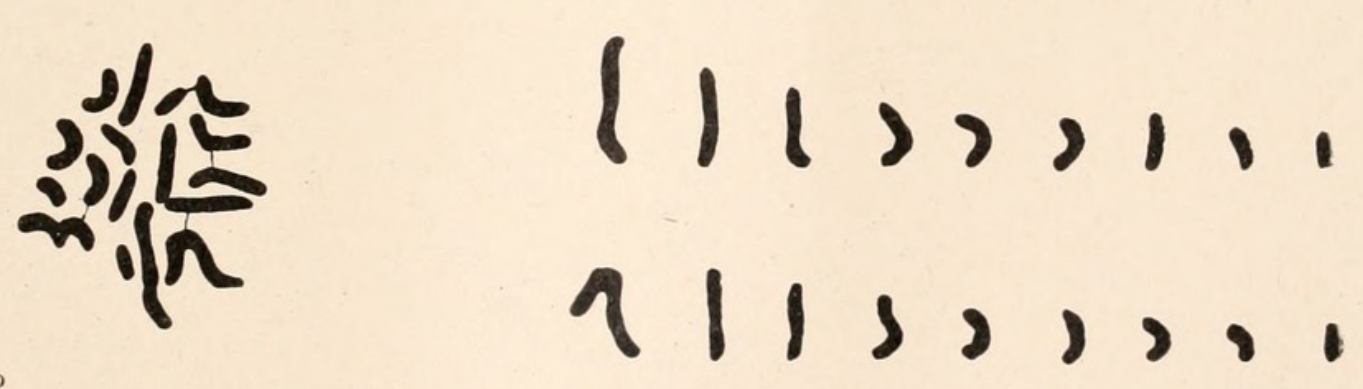




Explanation of Plate iII.

Diabrotica.

Fig. 9. Ectoderm, 2I chromosomes.

FIG. I0. Neuroblast, 2I chromosomes.

FIG. II. Ectoderm, 22 chromosomes.

FIG. I2. Tetrads of first maturation division of the egg. 


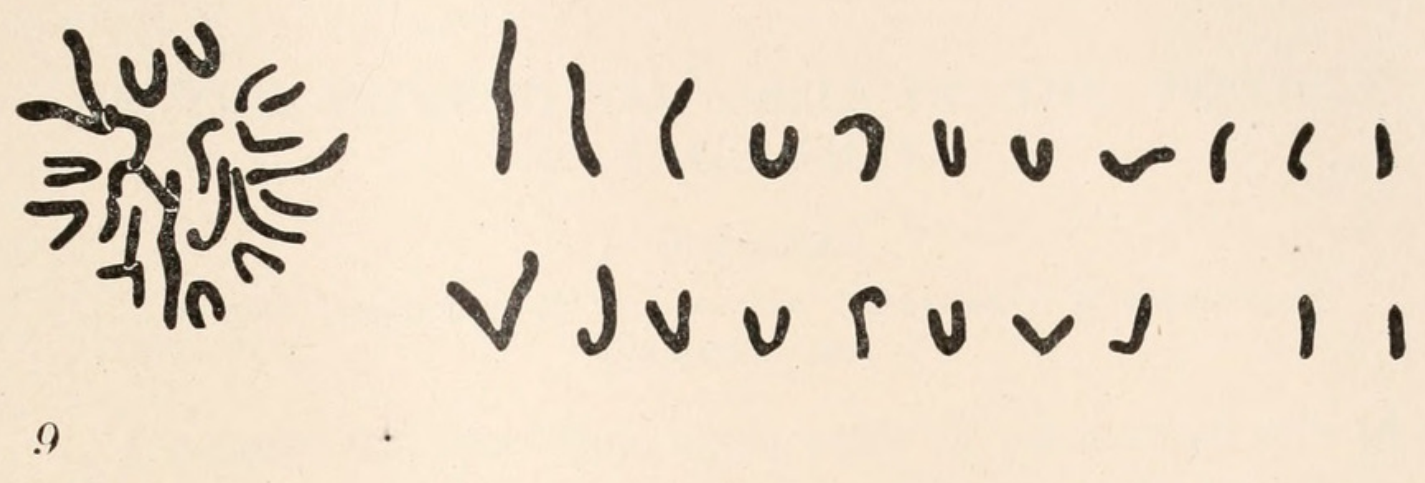

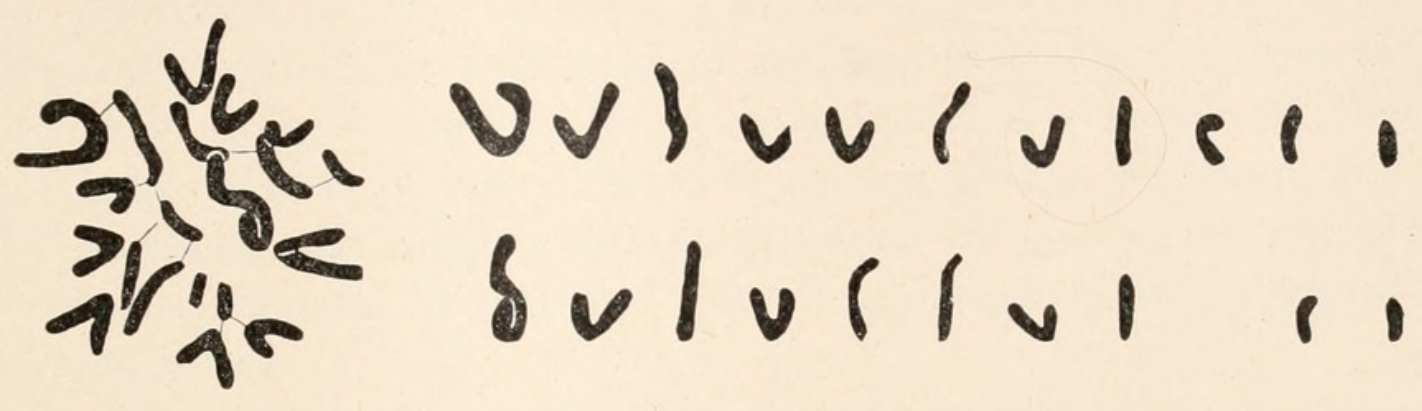

10

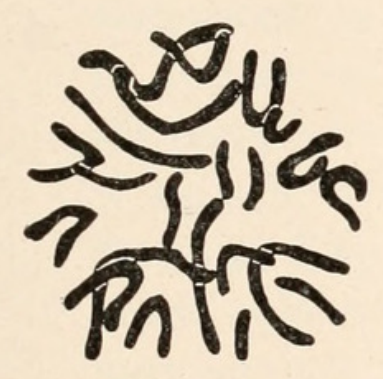

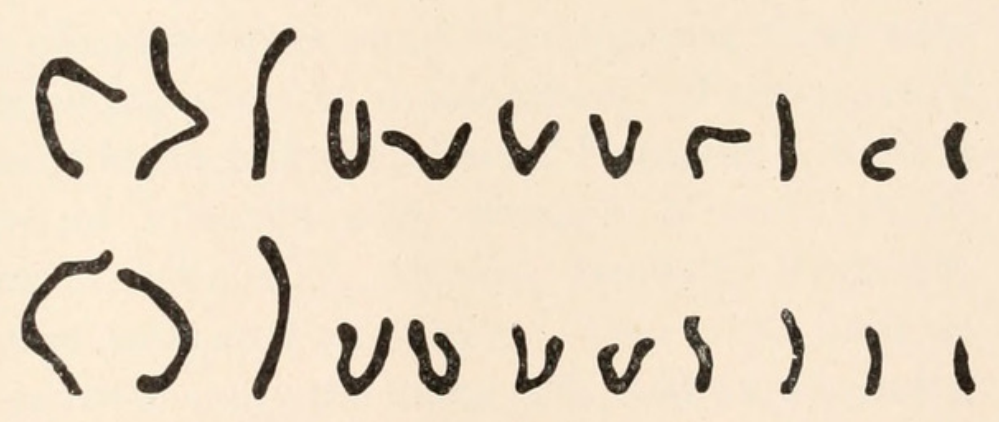

11

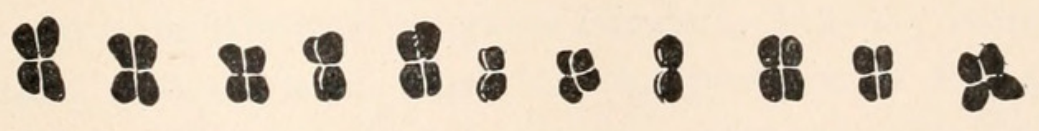





\section{ON THE INTERSTITIAL CELLS OF THE TESTICLE IN DIDELPHYS.}

\section{J. DUESBERG,}

Carnegie Institution of Washington, Department of Embryology, BAltimore, MD.

I completed a short time ago a study of the seminal cells of Didelphys, to appear (I9I9) in Contributions to Embryology, published by the Carnegie Institution of Washington, in a memorial volume dedicated to the late Professor Franklin P. Mall. While making that investigation I was struck by the large number of interstitial cells present in the testicle of the opossum, and, upon closer observation, by the complexity of their structure. I therefore determined to undertake a study of these cells.

The material upon which it was based consisted of nine animals. Five were full grown, a sixth exhibited all stages of spermiogenesis except the very last - i.e., the formation of the spiral filament at the expense of the chondriosomes - and the remaining three were in a much less advanced stage of development. Fragments of the testicle were fixed in the following fluids: Hermann's, Ramon y Cajal's mixture of formalin and uranium nitrate (I9I2), Bouin's, Flemming's, Altmann's, Meves', Benda's, Regaud's, acetic sublimate and saturated sublimate. Two adult animals were sacrificed in order to study the living cells, and were injected with a solution of janus-green $(\mathrm{I}-\mathrm{IO}, 000$ in 0.85 per cent. salt solution). I am greatly indebted to Professor E. V. Cowdry for his help in carrying out these experiments.

Of the above mentioned reagents Benda's, Meves', Regaud's and Altmann's fluids were used for the purpose of fixing the chondriosomes. To stain these bodies iron-hematoxylin, Benda's and Altmann's methods, and a combination of acid fuchsin and methylgreen were employed. Ramon y Cajal's mixture of formalin and uranium-nitrate was applied in order to bring into evidence the apparatus of Golgi. The best preparations were 
obtained by leaving the pieces in the fixative for 9 hours, in the silver nitrate 37 hours, and in the developer I4 hours. Instead of other complicated procedures, at the suggestion of Professor Cowdry I used the following method in the treatment of the sections: The slides were first immersed in o.I per cent. gold chloride for $2-3$ hours; then in 5 per cent. hyposulphite $20-30$ minutes. The results were excellent. Probably any nuclear dye could be used as a counterstain. I resorted to Ehrlich's hematoxylin, safranin, and methyl green (Cowdry, I9I6), which in a concentration of one half per cent., applied for 30-6o seconds, gives a very sharp contrast to the black color of the apparatus and the pale background. For reasons to be made clear later on, special methods (Mallory's, safranin-light green, and a combination of Congo red, iron-hematoxylin and light green) had to be used for staining the connective tissue. In the application of these, especially of the latter method, Professor Van der Stricht kindly gave me the benefit of his wide experience. It may be worth while to state in passing that Mallory's method gives just as good if not better results after fixation with Flemming's fluid (modifications of Benda and of Meves included) as after sublimate or similar fixatives.

Concerning the structure of the interstitial cells in the opossum, I find in the literature only two short notes; one by Whitehead (I908), the other by Jordan (I9I I). Whitehead states that these cells contain no fat. Jordan represents the mitotic division of the interstitial cells and mentions their chondriosomes. Data on the structure of interstitial cells in other mammals, on the other hand, are abundant and will be referred to when occasion arises.

In accord with the description of a number of authors, notably Reinke (I896), Lenhossek (I897), Bouin and Ancel (I903), and Winiwarter (I9I2, I), I found both single and double-nucleated interstitial cells (Figs. 2 and 7 ), although the latter are of far less frequent occurrence. Most of the nuclei show a marked depression on one side (Figs. I, 3, 5, 9 and Io); only in material fixed with Regaud's fluid is this peculiarity of structure not visible, probably because the nuclei swell somewhat in this fixative. The process of formation of the double nuclei has not 
been observed but is probably amitosis. Perhaps the nuclear depression just mentioned may be considered as an indication of direct division, but it must be stated that the number of cells in which this was noted greatly exceeded the number of - binucleated cells. Mitotic division of the interstitial cells in the opossum, although observed occasionally, is rare. Jordan (I9II, Fig. 7) has mentioned it.

The structure of the groundsubstance of the protoplasm varies considerably after the different fixatives. After all reagents that preserve the chondriosomes it appears homogeneous and exhibits a remarkable affinity for a number of dyes. In preparations made after Benda's method it stains intensely with sulfalizarin. Acid fuchsin is retained by it so tenaciously that the seminal epithelium usually has to be almost entirely unstained in order to obtain the proper grade of differentiation in the interstitial cells. Mulon (I9I I, I and 2) describes in the cells of the cortical suprarenal, in the corpora lutea and in the interstitial cells of the ovary, an amorphous, siderophile or osmiophile substance which, he supposes, is formed by the coalescence of chondriosomes. This substance he considers as a secretion which accumulates in the cell and is finally eliminated in bulk. Athias (I9II), however, believes in the presence of a diffuse lipoid formed at the expense of poorly preserved chondriosomes. It is possible that the diffuse substance observed in my material may be the product of secretion, as we shall later see, but it certainly has nothing to do with artificial or natural disaggregation of the chondriosomes, for these bodies appear well preserved within it.

Lenhossek (1897) was the first author to describe the centers of the interstitial cell. In man he describes a darker inner zonean "endoplasm" which corresponds obviously to the idiosome, ${ }^{1}$ although he was not able to demonstrate the presence of centrioles within it. These have been recently brought into evidence in human material by Winiwarter (I9I2, I), who found them to be rod-shaped. In the interstitial cells of the cat Lenhossek undoubtedly saw both the idiosome and the centrioles. In the opossum I find that there exists in most of the interstitial cells,

\footnotetext{
${ }^{1}$ In future I shall adopt the spelling idiosome, as proposed by Regaud (I9IO), instead of idiozome, for the reasons assigned by that author.
} 
in close proximity to the nucleus, a differentiation of the cytoplasm (Figs. I, 2 and 8). This zone contains the centrioles of the resting cell and is undoubtedly to be considered as an idiosome. In contradistinction to what one observes in the seminal cells, the idiosome of the interstitial cells is not sharply delimited by a special cortical layer. It appears most clearly in material fixed with Bouin's fluid or with any reagent containing osmic acid. It is frequently found located in the nuclear depression, as Ballowitz (I898, I900) observed it, but not always so (for instance, Fig. I). While two centrioles exist in the cells provided with only one nucleus, I find, as did Winiwarter in human material, that binucleated cells have four centrioles, and in some cases these are obviously rod-shaped (Fig. 2).

The extreme results obtained for the apparatus of Golgi by the Ramon y Cajal method are illustrated in Figs. 3 and $4 \cdot^{1}$ In the first, the apparatus appears as a dense reticulum, in the second the reticulum is much looser. Normally, the apparatus is concentrated at one pole of the nucleus; cases like the one represented in Fig. 4, in which one or two branches of the network extend to the opposite pole and surround the nucleus completely, are exceptional. The apparatus is found either in the nuclear depression or in another place (Fig. 3). It behaves in this respect like the idiosome, and consequently nothing definite can be said concerning the topographical relationship of these two bodies. Nothing, however, would seem to militate against the existence of a close relationship such as has been established for a large number of other cells (for literature, see Duesberg, I9I4, I9I9). Other investigations will probably help to solve the problem, the present one being, to the best of my knowledge, the first on the apparatus of Golgi in the interstitial cells of the testicle. Concerning the interstitial cells of the ovary, we have the data of Cattaneo (I9I4) and Kulesch (I9I4).

While the interstitial cells of the opossum contain little fat, it would not be correct to say, with Whitehead, that they contain none at all. As a matter of fact, while the number of fat droplets is usually small, it varies with each animal. In other mam-

${ }^{2}$ Another drawing of an interstitial cell in the testicle of the opossum, with the apparatus of Golgi, will appear in another paper (I9I9, Fig. 34). 
mals (rat, guinea-pig, rabbit, dog and man) Ciaccio (r9Io) describes a number of granules and vesicles which, after fixation with his special methods, stain with Sudan. Ciaccio considers these bodies as formed by a lipoid substance which, in his opinion, has a great analogy to the substance of the chondriosomes. Although none of my material was fixed exactly according to Ciaccio's prescription, I applied his method of staining to material fixed in Regaud's fluid and subsequently kept in 3 per cent. bichromate for a week, a procedure which is similar to Ciaccio's method I. The results were identical with those obtained from preparations fixed with reagents containing osmic acid; that is to say, Sudan apparently stained in red what would be stained black in osmic acid. This conclusion was reached through the study of the seminal epithelium, in which the fat droplets have a characteristic arrangement, rather than through the study of the interstitial cells in which no such regular arrangement exists.

Pigment, which has often been found in other mammals and quite lately in the woodchuck by Rasmussen (I9I7), does not appear to exist at all in the interstitial cells of the opossum. Crystalloids, on the other hand, are found in many cells and are of two types. So far, those described for the first time by Reinke (I896) are supposed to exist only in human material, although Mathieu (I898) mentions the presence of "filaments cristalloïdiens" in the interstitial cells of the testicle in the cat. The plates accompanying his paper, however, are by no means clear. In the opossum many interstitial cells contain bodies similar to Reinke's crystalloids, although smaller and not so abundant (Fig. 6). They appear most clearly after fixation with Benda's or Meves' fluid, and can be seen in all other material except that fixed with Regaud's reagent; after the application of Benda's method they usually stain in brown. These bodies are rather short and thick; their ends are not pointed but blunt. Frequently they appear to be formed of two substances-a darker peripheric, and a lighter central one. In most cases only one crystalloid is found in a cell; occasionally, however, their number is increased, although they are never so abundant as Reinke's crystalloids in man. Sometimes a large crystalloid 
will appear to be split at one end. The resemblance of these bodies to the crystalloids of Reinke is accentuated by the fact that, in rare cases, they are found surrounded by a clear space, located in a sort of vacuole.

The second type is not quite so frequently noted as that just described. It is represented by what appear to be thin rods, pointed at both extremities, which vary considerably in length in the different cells. The shorter ones are usually straight, the larger ones curved. In most of the cells they are multiple (Fig. 5). These, too, are seen most clearly after fixation with Benda's fluid, but are preserved in other fixatives also. In Regaud's preparations, however, I was never able to find them. Similar bodies exist in the cells of Sertoli. If I were to venture a comparison it would be to liken them to the bodies described by Lubarsch in the human testicle under the name of CharcotBöttcher's crystals. The so-called Lubarsch crystals are, as Lenhossek has pointed out, located in the spermatogonia, but there is in the seminal epithelium another form of crystalloids, also described by Lubarsch (the Charcot-Böttcher crystals), which are larger and are located in the cells of Sertoli. According to Montgomery (I9II) and to Winiwarter (I9I2, 2), the two forms are in genetic relation. Montgomery, who unfortunately failed to compare his observations with those of previous authors, described them in the "antepenultimate spermatogonia" of man as "rods," and came to the interesting conclusion, corroborated by Winiwarter (I9I2, 2), that "the presence of the rod determines the line of the Sertoli cell" (p. 368). Crystalloids have also been found in the Sertoli cells of the pig by Bouin and Ancel (I903, Fig. II) and possibly in the cat by Hague (I9I4). I did not see anything resembling the numerous small crystalloids described by Lenhossek (p. 68, Figs. 2, 3 and 4), which correspond, in my opinion, to Winiwarter's (I9I2, I) "grains riziformes."

The chondriosomes of the interstitial cells in mammals have been seen by Jordan (I9II), Winiwarter (I9I2, I), and Rasmussen (I9I7). As stated above, Jordan merely mentions their presence in the opossum. Winiwarter gives a longer account of these bodies in man, where he finds both granules and rods. Rasmussen describes in the woodchuck small granules, "the only 
thing of a mitochondrial character that could be demonstrated in the interstitial cell at any time," a description which is rather unsatisfactory. My own observations show that the chondriosomes are exceedingly numerous and that they are mostly rods, short and curved. They are crowded into several heaps, some of which are often seen in close proximity to the nucleus. Fig. 7, drawn from a preparation fixed and stained after Benda, gives what should be considered their natural aspect, as they appear exactly alike in teased preparations after injection of janus-green. It is surprising how easily the interstitial cells take up the vital dye, in contradistinction to the seminal cells, which it is very difficult to stain in vivo: the reason for this difference is obviously the presence of a sheath of connective tissue around the seminiferous tubule. After fixation in Regaud's fluid the appearance is not altered; it must be stated, however, that after the action of that fluid, which has a great power of penetration, the chondriosomes can be well preserved all through the piece, while in Benda's material they are well fixed only in a very thin layer of tissue, at the periphery. The chondriosomes seem to be especially labile in the interstitial cells. As usual, the figures of deformation are, in the first stages, granules and vesicles. Of other forms, which I am led to consider as related to the chondriosomes, I shall speak later.

Winiwarter (I9I2, I) mentions the existence of transitional forms between the chondriosomes and the crystals, but does not conclude definitely in favor of a genetic relationship. As an argument in favor of such a relationship one could bring into the field the following observations of that author: In the fetus chondriosomes only are present in the interstitial cells, the other elements appearing afterward. I regret to say that I have no information to offer on this point.

In all my material, except when again fixed with Regaud's fluid, cells are found, which contain a number of granules. These granules can be stained by different methods. I am strongly inclined to consider them as a secretion product, a question which will be taken up again shortly. As stated, these granules are not constant nor are they very abundant in one cell: not to be compared with the bulky masses represented by Bouin and Ancel (1903) for instance, in Fig. 7 of their paper. 
We come now to the description of a most interesting condition in these interstitial cells of the opossum, a condition which I noted first in preparations stained and fixed after Benda, where it is most conspicuous. It can be seen also, however, in other preparations, such as Flemming's, Meves', Hermann's and Bouin's. A substance, which sometimes appears granular, at other times amorphous, fills the intercellular spaces. Its quantity is variable; some interspaces show so little of it as to escape notice, others are widely dilated by the presence of large quantities of the substance, as shown in Fig. I3. It is most conspicuous in preparations made after Benda's method because it takes up avidly the crystal-violet, in striking contrast to the light-brown color of the background and of the nuclei. The same substance stains intensely with safranin and iron-hematoxylin; in the Mallory method it takes up the orange and is consequently rather inconspicuous.

A closer investigation shows that from these intercellular spaces processes penetrate into the cell-body (Figs. I2 and I3). While most of these processes look like the substance accumulated in the intercellular spaces, some have the sharp appearance of a more definite structure, such as laminæ of some sort, and my first supposition was that I had to do with processes of connective tissue penetrating into the cell-body, such as have been described for large nerve-cells. A study of preparations stained especially for the connective tissue failed, however, to substantiate this opinion. After Mallory's stain, for instance, I could not find any such process electively stained in blue. While the thinnest fibrils of connective tissue in the sheath of the vessels and the connective membrane of the seminiferous tubules gave a typical collagenous reaction, in the same preparations the intracellular processes always were stained in orange like the intercellular substance. As a matter of fact, the study of these preparations corroborates Lenhossek's description (p. 78). The interstitial cells lie in heaps or irregular rows separated by the larger vessels. It is quite exceptional to see a process of the connective sheath of these vessels penetrate into a group of interstitial cells. The cells are, as a rule, separated only by intercellular spaces, virtual or real, and perhaps also in certain 
places by small capillaries. I conclude, therefore, that the intracellular processes are formed by the substance filling the intercellular spaces, a substance which, in my opinion, represents the product of secretion. If this interpretation be correct, as I believe it to be, here is a remarkable instance of a gland with internal secretion, in which the product of secretion can be followed, owing to its staining qualities, from within the cell into the passage of excretion. Favorable sections, like that represented in Fig. 13, carry one even a step farther and show the same product in a vessel.

What, then, is the real nature of these intracellular and intercellular spaces, and of these vessels with which the intercellular spaces seem to be in some way connected? The penetration of lymphatics into a cell, not to speak of the much discussed and very disputable conditions described by Adamkiewicz (I886, I900), Browicz (I902, I and 2), Schäfer (I902, I903), Schlater (I902) and others, has been repeatedly reported. At first Holmgren interpreted his trophospongium as such. Among the more recent observations I may mention those published by Ciaccio (I903), Felicine (I904), Kumita (I909) and Matsunaga (I909). The first three authors studied the suprarenal. Ciaccio, after the application of Golgi's method, and Felicine and Kumita, as a result of injections, come to the conclusion that there exists a pericellular net of capillaries which send processes into the cells. Matsunaga has published similar results after his study of the thyroid by the injection method. Kumita, however, wonders whether these intracellular processes are really vessels, or "ob sie nicht durch einen sekretorischen Zellzerfall zustande gekommen sind" (p. 325). This last hypothesis, however, in his opinion can hardly be reconciled with the fact that the injected mass never spreads over all the cell, and that the intracellular space has a definite shape, ending often in a swelling in the neighborhood of the nucleus. No matter what the interpretation may be in these cases, it appears to me that the intracellular processes in the interstitial cells of the opossum are not well defined canals of any kind - neither processes of lymphatics nor intracellular ducts. They are always exceedingly irregular in appearance and are never seen in an empty condition, but always 
as processes of the intercellular substance. No structure, at least no visible structure, appears to be the substratum of these processes. They represent, in my opinion, something like the "sekretorischer Zerfall" supposed by Kumita, or the accumulation along certain lines, perhaps in connection with protoplasmic currents, of the product of secretion. Nor do the intercellular spaces represent capillaries. Their irregular shape and the fact that no endothelium seems to line them, show that they are, as I have called them so far, merely intercellular spaces which become more or less dilated according to the quantity of secretion which is accumulated in them. Finally, that the space into which this substance is poured is a capillary cannot be doubted, for it is lined with a well-recognizable endothelium. Whether, on the other hand, this capillary is a lymphatic or a bloodvessel is not so easy to tell, and must be decided by methods other than those employed by me. Nor do the bibliographic data give any definite clue. Regaud (1897), who has made a special study of the distribution of the lymphatics in the mammalian testicle, finds that it is exceedingly variable in the different species. He distinguishes three types: One in which the lymphatic net is exclusively peritesticular; another in which the lymphatics penetrate as far as the corpus Highmori and the interlobular septa; and a third, in which the lymphatics form a network around the seminiferous tubules. It may be worth while to determine sometime, in connection with the problem of the excretion from the interstitial cells, to which type the opossum belongs.

To sum up, the product of secretion is accumulated in the interstitial cell, then discharged into the intercellular spaces, and from there passes into the circulation. Although this is one of the clearest instances in which the secretion product of a gland with internal secretion actually could be followed from the glandular cell into the vascular system, owing probably to the favorable staining properties of the secretion product, there are similar observations in the literature. Reinke has already called attention to the common staining properties of his crystals and the testicular lymph, and concludes in favor of the passage of the substance of these crystals in to the lymphatics. Lenhossek 
mentions (p. 78) the presence of a coagulum into the "lymphatic spaces" of the human testicle, and Sénat (I900, p. 65) writes: "Chez tous les rats dont les testicules ont été examinés, environ une dizaine, C. Regaud a rencontré dans les espaces conjonctifs une substance particulière, évidemment coagulée par les réactifs. ... Cette substance a les mêmes réactions colorantes que le contenu protoplasmique des cellules interstitielles. Elle forme des flaques, parfois très étendues, qui englobent ces cellules. Cette substance parait être le produit de secrétion des cellules interstitielles; peut-être résulte-t-elle de leur désintégration." Bouin and Ancel (I903) state: "Une fois gorgées de leur produit de secrétion, les cellules l'expulsent au dehors; aussi le retrouve-t-on en grande abondance dans les espaces laissés libres entre ces cellules. . . . De plus, on voit également de semblables formations dans les vaisseaux sanguins et lymphatiques" (p. 476).

Something similar was found by the same authors (I904) in their "cellules à granulations xanthiques;" that is to say, special interstitial cells which appear in the testicle of the horse fetus. Here, however, the process goes so far that after the excretion, "la cellule est réduite à son noyau et à une fäible quantité de cytoplasme, jaune noirâtre après emploi de la méthode de Benda. Nous n'avons pu discerner si ces éléments étaient susceptibles de recommencer un nouveau cycle secrétoire ou s'ils disparaissent après la phase d'excrétion, à la manière des cellules glandulaires holocrines" (pages CXLIV-CXLV). Finally, Popoff (I909), describing the interstitial cells in a human fetus $14 \mathrm{~cm}$. long, says (pp. 447-448): "Dans un grand nombre de cellules, on observe des formations vacuolaires, à contours précis, entourant partiellement le noyau ou occupant au sein du protoplasme une place quelconque. Le nombre, la forme et les dimensions de ces vacuoles sont des plus variables. Tantôt, elles se présentent sous formes de fentes étroites et allongées, à direction inconstante; tantôt c'est un petit canal irrégulièrement calibré, incurvé ou une lacune en forme de croissant diversement orientée. Des formations analogues, peut-être en communication avec les précédentes, se rencontrent encore entre les cellules. Le tissu interstitiel est traversé par un grand nombre de capillaires sanguins, dont quelques-uns ont à peine le diamètre d'un 
globule rouge. Un examen attentif révèle un rapport étroit des capillaires avec les espaces intercellulaires."

Similar observations on other glands with internal secretion have been made, notably the following: Hultgren and Andersson (I899) describe the secretion products in the medullar part of the suprarenal in mammals as granules which are expelled into the bloodvessels (see pp. 268-269): "Dies geschieht entweder durch das Wandern der kleinen Körner durch die Wandung der Gefässe, wie dies besonders an den Venen beobachtet wird, oder, es wird das Endothel der Capillaren an gewissen Stellen zersprengt und die Zellen treten mit dem Gefässlumen in direkter Verbindung."

In this case the fate of the secretion product is very clearly shown. Colson (I9IO) finds in the same gland intercellular spaces filled with the substance secreted by the cells. Apparently the cell-bodies are, to a certain extent, liquified, since there appear to be no definite boundaries between cells and intercellular spaces. These spaces are, in Colson's opinion, the same that Kumita, as reported above, found in communication with the lymphatic system. Van der Stricht (I9I2), in the corpus luteum, finds also that the secretion product of the lutein cells is accumulated in the intercellular spaces; in some cases this intercellular space is an axial cavity around which the cells are oriented as in an epithelium.

Finally, there are within the interstitial cells certain very peculiar constituents, which are represented in Figs. 6, 9, IO, I I and I3. They have the appearance of a sort of huge network. In a number of cells the meshes of this network are small and the trabeculæ are thin, while in others the meshes are wide and the trabeculæ quite thick. The extremes are shown in Figs. 9 and II, but all stages of transition between these two types can be found; one of these is seen in Fig. Io. The resemblance of this network to some apparatuses of Golgi is indeed very striking, but the results obtained with the method of Ramon y Cajal, which have already been described, show that the apparatus of Golgi in these cells is something entirely different. There is also a certain resemblance to some of the trophospongia pictured by Holmgren (I904), a point which will 
shortly be discussed. In most cases, it is quite apparent that this peculiar formation does not invade the entire cell-body, but leaves two parts free; first, a space located in the immediate neighborhood of the nucleus, which it is safe, I believe, to consider as corresponding to the idiosome; second, the periphery of the cell. There are, however, exceptions to the latter rule, as in a number of cases some trabeculæ are seen very close to the cell-boundary.

The question arises: is there any connection between this network and the intracellular accumulations of the secretion product? In many cases it would appear as though both formations were in continuity, and that consequently the network were merely an extension of the intracellular processes throughout the cell-body. I am, however, of a different opinion. To me the network is the product of a transformation of the chondriosomes under special conditions of imperfect preservation. I am perfectly aware that no such forms have been described heretofore. The only thing with which I can, to a certain extent, compare these structures are the chondriosomes in the seminal cells of Scolopendra cingulata as represented (in my opinion imperfectly preserved) by Bouin (1905) especially in his Figs. I3, I4 and I5. The basis for this interpretation is that this network is found only in material fixed with Benda's or Meves' fluid (after Altmann's fixation the interstitial cells kept the acid fuchsin with such tenacity that no definite conclusion could be reached), but only in the deeper parts of the pieces; that is, where the chondriosomes are not well preserved. It is not found in material fixed in Regaud's fluid, but I assume that, as the latter reagent penetrates better than those just mentioned, it never gives the chondriosomes a chance to produce such distorted figures. As a matter of fact, they are pretty well preserved all through the pieces, and the only modified forms that appear in that material are the vesicles - the well-known first stages of chondriolysis. On the other hand, the secretion product is preserved by a number of reagents which do not fix the chondriosomes. The staining reactions are also different and point toward the chondriosomal nature of the network. Generally speaking, the network is stained in purple after Benda's method, that is, 
like the product of secretion (the very large networks, such as that represented in Fig. I I, may make exception and stain with alizarin); but if we stain with safranin, we find that the secretion product alone takes up the dye and stands out conspicuously. A second reason which argues in favor of my interpretation is the existence of all possible transition forms between the network and the first stages of chondriolysis. In the cell represented in Fig. 8 there are some of those vesicles, which, as we know, result from the artificial fragmentation and swelling of the chondriosomes. There are present also some forked forms, which are probably produced by the confluence of the swollen chondriosomes, and give an indication of how a network can be built at the expense of the normal, independent chondriosomes. Again, although at times the network appeared to be connected with the intracellular accumulations of secretion, on closer examination no such connection could be actually established. Finally, there is a difference in the structure; the product of secretion usually appears granular, while the substance of the network is homogeneous.

As stated above, I consider this network as produced by the transformation of the chondriosomes, not by a natural process, as is well understood, but by an artificial one. Of any intervention on the part of the chondriosomes in the formation of the secretion product, an intervention which in a number of cases seems to me entirely plausible, nothing could be seen here. Under what form does the product of secretion of the interstitial cells make its appearance? 'I have mentioned the presence of granules that are preserved by a number of fixing reagents. These granules are certainly secreted by the cell, but in my opinion they are too scarce and inconstant to be considered as the forerunners, or at least the only forerunners, of the product of the cell. One must consequently admit that the bulk of the secretion makes its appearance in a diffuse or non-stainable form. I would suggest, without, however, being able to substantiate that opinion, that the product of secretion is represented by the substance which is responsible for the diffuse staining of the protoplasm, something like Mulon's osmiophile or siderophile substance. But there is no indication in this case, as Mulon states it, that 
this substance be formed by the coalescence of the chondriosomes, nor that the elimination be accompanied by a partial destruction of the cell.

While the existence of these strangely deformed chondriosomes is perhaps not very interesting in itself, it calls the attention of the cytologist to the possibility of a confusion between different cellular structures. Regardless of whether or not my interpretation be correct, two things are evident: (I) That the network has nothing whatever to do with the apparatus of Golgi, as is shown after the application of Ramon y Cajal's method; (2) that it bears a remarkable resemblance to many of the structures described as the apparatus of Golgi. There is one instance in the literature in which the chondriosomes, after application of a silver method, have been mistaken for the Golgi's apparatus (the cartilage cell, by Pensa, I90r), ${ }^{1}$ and it is possible that a similar error is also the basis for Monti's interpretation of this structure in the adult nerve-cell. According to that writer (I9I5), what was described in these cells as the apparatus of "Golgi is identical with the chondriosomes. I have discussed her paper extensively in another place (I9I9). Having since discovered this network in the interstitial cells of the opossum I am inclined to believe that Monti has been misled by a similar appearance.

Another point which I feel should be touched upon in this connection is Holmgren's trophospongium theory. In its latest form this theory claims the existence in a tissue of two types of cells - the parenchymal cells and the trophocytes. The former are penetrated by processes of the trophocytes, processes which form the trophospongial net and become, under certain circumstances liquified, forming the "Kanälchen des Trophospongiums." The rôle of the trophocytes is, as their name implies, a trophic one. While Holmgren himself has never published anything on the interstitial cells of the testicle, these are the only objects for which his theory has found whole-hearted support. In one paper Bouin and Ancel (I905, I) describe, in the first generation of interstitial cells in the testicle of horse fetuses from 22 to 42 $\mathrm{cm}$. long, a structure which is "l'homologue du trophosponge de

${ }^{1}$ Pensa himself later on (I9I3) acknowledged his mistake. 
Holmgren" (p. 395). This trophospongium belongs to the diffuse type. It appears either as a canalicular network (p. 399), or as a solid network (p. 404), and the authors suppose that it is the "transformation substantielle de ce trophosponge qui donne naissance au réseau des canalicules du suc, selon la conception de Holmgren" (p. 404). In that paper Bouin and Ancel are quite reserved as to the existence of connections between this network and trophocytes, but they subscribe entirely to Holmgren's conception in a note published the same year $(1905,2)$, evidently written subsequent to the other. According to their description the young interstitial cells of the testicle of the horse are penetrated by processes of cells of connective tissue acting as trophocytes. These processes are later transformed in to a system of canals which open at the periphery of the interstitial cells. In these later stages they still surround, but can no longer be followed within the interstitial cells.

Whether or not Bouin and Ancel are still upholding their view I do not know, but it should be pointed out that no mention of it, or of the "canalicules du suc" is made in Bouin's description of the interstitial cells of the testicle, in Prenant, Bouin and Maillart's Traité d'Histologie. I would call attention also to the fact that the only figure in the above mentioned papers (Fig. 3, I905, I) that shows anything like what the authors describe, in reality rather contradicts that description. This figure represents a group of interstitial cells containing something that resembles the "canalicules du suc"; but at the same time there is no trace of trophocytes, cells of connective tissue, or any connective tissue at all, between these cells, and consequently no indication of a connection between such cells and the canalicular apparatus. This is the crucial point. Aimé (I907) also has described in the interstitial cells of the ovary intracellular spaces whose existence is beyond doubt, but he states definitely: “Nous n'avons pas vu de relations entre ces canaux et les cellules conjonctives entourant les cellules interstitielles" (p. I2I, Fig. II). The first point I would dispute is the existence of the trophocytes, at least in the opossum. As stated above, in a heap or row of interstitial cells the cells themselves are not separated by connective tissue or cells of any kind. On the other hand, if 
Bouin and Ancel met with intracellular accumulations of an unstainable product of secretion, or such deformed chondriosomes as I have described above, I can readily see, from my own observations, how they arrived at their interpretation.

Concerning variations in number, size or structure of the interstitial cells with the development of the testicle (the most recent investigations upon these points being those of Rasmussen, I9I7), I have little to say. The only thing which I noted was that, in the youngest testicles preserved (those in which the process of spermatogenesis had just begun) the interstitial cells were smaller than in the adult.

Adamkiewicz, A.

\section{BIBLIOGRAPHY.}

'86 Der Blutkreislauf der Ganglienzelle. Berlin, Hirschwald. ${ }^{1}$

'oo Zum Blutgefässapparat der Ganglienzelle. Anat. Anz., Vol. I7.

Aimé, P.

'o7 Recherches sur les cellules interstitielles de l'ovaire chez quelques mammifères. Arch. de Zoöl. exp. et. gén., nouv. sér., Vol. 7 .

Athias, M.

'I I Observations cytologiques sur l'ovaire des mammifĕres. I. Les cellules interstitielles de l'ovaire chez le cobaye (foetus à terme et nouveau-né). Anat. Anz., Vol. 39.

Ballowitz, E.

'98 Zur Kenntniss der Zellsphäre. Eine Zellstudie am Salpenepithel. Arch. f. Anat. u. Phys. Anat. Abt.

'oo Ueber das Epithel der Membrana elastica posterior des Auges, seine Kerne und eine merkwürdige Struktur seiner grossen Zellsphären. Ein Beitrag zur Kenntniss der Organisation der Zelle. Arch. f. mikr. Anat., Vol. 56.

Bouin, P.

'o5 Ergastoplasme, pseudochromosomes et mitochondria. A propos des formations ergastoplasmiques des cellules séminales chez Scolopendra cingulata. Arch. de Zoöl. exp. et gén., nouv. sér., Vol. 3.

Bouin, P., et Ancel, P.

'o3 Recherches sur les cellules interstitielles du testicule des mammifères. Arch. de Zoöl. exp. et gén., nouv. sér., Vol. I.

'04 Recherches sur la structure et la signification de la glande interstitielle dans le testicule normal et ectopique du cheval (Note préliminaire). Arch. de Zoöl. exp. et gén., nouv. sér., Notes et Revue, Vol. 2.

'o5 I. La glande interstitielle du testicule chez le cheval. Arch. de Zool. exp. et gén., nouv. sér., Vol. 3 .

'05 2. A propos du "trophospongium" et des "canalicules du suc." C. R. Soc. Biol. Paris.

Browicz, T.

'02 I. Die Beziehungen zwischen den intraacinösen Blutkapillaren und den intracellulären Ernährungskanälchen der Leberzelle. Anat. Anz., Vol. 22.

1 Not available. 
'O2 2. Meine Ansicht über den Bau der Leberzelle. Virchow's Arch., Vol. I68. Cattaneo, D.

'I4 Richerche sulla struttura dell'ovario dei Mammiferi. Arch. ital. di Anat. e Embr., Vol. I2.

\section{Ciaccio, C.}

'o3 Communicazione sopra i canaliculi di secrezione nella capsule soprarenali. Anat. Anz., Vol. 22.

'ı Contributo alla distribuzione ed alla fisio-patologia cellulare dei lipoidi. Arch. f. Zellf., Vol. 5.

\section{Colson, R.}

'ro Histogenèse et structure de la capsule surrénale adulte. Arch. de Biol., Vol. 25 .

\section{Cowdry, E. V.}

'i6 The structure of chromophile cells of the nervous system. Contr. to Embr. Carnegie Inst. of Washington, Vol. 4.

\section{Duesberg, J.}

'I4 Trophospongien und Golgischer Binnenapparat. Anat. Anz. Ergänzungsheft (Verh. d. anat. Geslls. Innsbruck).

'I9 Cytoplasmic structures in the seminal epithelium of the opossum (Didelphys virginiana). Contr. to Embr. Carn. Inst. of Washington. Memorial Vol. for Prof. F. P. Mall.

\section{Felicine, L.}

'o4 Ueber die Beziehungen zwischen dem Blutgefässsystem und den Zellen der Nebenniere. Arch. f. mikr. Anat., Vol. 63.

\section{Hague, F. S.}

'I4 Numerical relation of spermatozoa to Sertoli cells. Kansas Univers. Sc. Bull., Voi. 9.

\section{Holmgren, E.}

'o4 Beiträge zur Morphologie der Zelle, 2. Verschiedene Zellarten. Anat. Hefte, Vol. 25.

Hultgren, E. O., und Andersson, Oskar A.

'99 Studien uber die Physiologie und Anatomie der Nebennieren. Skand. Arch. f. Phys., Vol. 9.

Jordan, H. E.

'I I The spermatogenesis of opossum (Didelphys virginiana), with especial reference to the accessory chromosome and the chondriosomes. Arch. f. Zellf., Vol. 7 .

\section{Kulesch, L.}

'I4 Der Netzapparat von Golgi in den Zellen des Eierstockes. Arch. f. mikr. Anat., Vol. 84.

\section{Kumita .}

'o9 Ueber die parenchymatösen Lymphbahnen der Nebenniere. Arch. f. Anat. und Phys. Anat. Abt.

\section{Lenhossek, M. von.}

'97 Beiträge zur Kenntniss der Zwischenzellen des Hodens. Ibid.

\section{Mathieu, Ch.}

'98 De la cellule interstitielle du testicule et de ses produits de secrétion (cristalloïdes). Thèse de Nancy. 


\section{Matsunaga.}

'o9 Die parenchymatösen Lymphbahnen der Thyreoidea und ihre Sekretion. Monti, R. Arch. f. Anat. u. Phys. Anat. Abt.

'I5 I condriosomi e gli apparati di Golgi nelle cellule nervose. Arch. ital. di Anat. e di Embr., Vol. I4.

Montgomery, Th. H., Jr.

'I I Differenciation of the human cells of Sertoli. BIOL. Bull., Vol. 2 I. Mulon, P.

'I I I. Sur une secrétion lipoïde nouvelle de la glande interstitielle ovarienne. C. R. Soc. Biol. Paris, Vol. 69.

'I I 2. Démonstration. C. R. Assoc. Anat. Paris (pages 33 I-332).

Pensa, A.

'or I. Osservazioni sulla struttura delle cellule cartilaginee. Boll. Soc. Med.Chir. Pavia.

'or 2. Demonstration von Präparaten über einen Netzapparat in den Hyalinknorpelzellen. Verh. anat. Gesells. Bonn.

'or 3. Observations sur la structure des cellules cartilagineuses. C. R. Assoc. Anat. Lyon.

'I3 La struttura della cellula cartilaginea. Arch. f. Zellf., Vol. XI.

Popoff, N.

'og L'ovule mâle et le tissu interstitiel du testicule chez les animaux et chez l'homme. Arch. de Biol., Vol. 24.

\section{Prenant, A., Bouin, P., et Maillart, L.}

'I I Traité d'Histologie, 2. Histologie et anatomie microscopique. Paris.

\section{Ramon y Cajal, S.}

'I2 Formula de fijacion para la demonstracion facil del apparato reticular de Golgi y apuntes sobre la disposicion de dicho apparato en la retina, en los nervios y algunos estados patologicos. Trab. Lab. Invest. Biol. Univers. Madrid, Vol. Io.

Rasmussen, A. T.

'I7 Seasonal changes in the interstitial cells of the testis in the woodchuck (Marmota monax). Am. Journ. of Anat., Vol. 22.

\section{Regaud, Cl.}

'97 Les vaisseaux lymphatiques du testicule et les faux endothéliums de la surface des tubes séminifères. Thèse de Lyon.

'ı Etudes sur la structure des tubes séminifères et sur la spermatogenèse

\section{Reinke, Fr.} chez les mammifères. Arch. d'Anat. micr., Vol. XI.

'96 Beiträge zur Histologie des Menschen. Arch. f. mikr. Anat., Vol. 47.

Schäfer, E. A.

'o2 On nutritive channels within the liver-cells, which communicate with the lobular capillaries. Anat. Anz., Vol. 2 I.

'o3 Dr. Emil Holmgren and the liver-cell. Ibid., Vol. 23.

Schlater, G.

'02 Kritisches zur Frage vom Bau der Leberzelle (vom intranukleären Hohlraum). Anat. Anz., Vol. 22.

Sénat, L.

'oo Contribution à l'étude du tissu conjonctif du testicule. Thèse de Lyon. 
Van der Stricht, 0 .

'I2 Sur le processus de l'excrétion des glandes endocrines: le corps jaune et la glande interstitielle de l'ovaire. Arch. de Biol., Vol. 27.

Whitehead, R. H.

'08 Studies of the interstitial cells of Leydig, 3. Histology. Anat. Rec., Vol. I. Winiwarter, H. von

'I2 I. Observations cytologiques sur les cellules interstitielles du testicule humain. Anat. Anz., Vol. 4I.

'I2 2. Etudes sur la spermatogenèse humaine, I. Cellule de Sertoli, 2. Hétérochromosome et mitoses de l'épithélium séminal. Arch. de Biol., Vol. 27. 



\section{EXPLANATION OF PLATES.}

All figures were outlined with a Zeiss camera-lucida, at the level of the stage of the microscope. Lenses used: for Figs. I-I 2, Zeiss apochr. immers. $2 \mathrm{~mm}$. (ap. I, 40), in combination with ocular I2; for Fig. I3, Zeiss apochr. imm. I mm. 5 (ap. I, 30), and ocular 6. Artificial light (gas).

\section{Explanation of Plate I.}

I. Interstitial cell with idiosome and 2 centrioles. Fixation and stain after Benda.

2. Interstitial cell with two nuclei, idiosome and 4 centrioles. Fixation and stain after Benda.

3. The apparatus of Golgi. Ramon y Cajal's method. Counterstain: Ehrlich's hematoxylin.

4. Another form of the apparatus of Golgi. Ramon y Cajal's method. Counterstain: methylgreen.

5. Interstitial cells with several crystals of the thin type. Fixation and stain after Benda.

6. A crystal of the thick type. Fixation and stain after Benda. The same cel shows part. of the network made up of modified chondriosomes. 


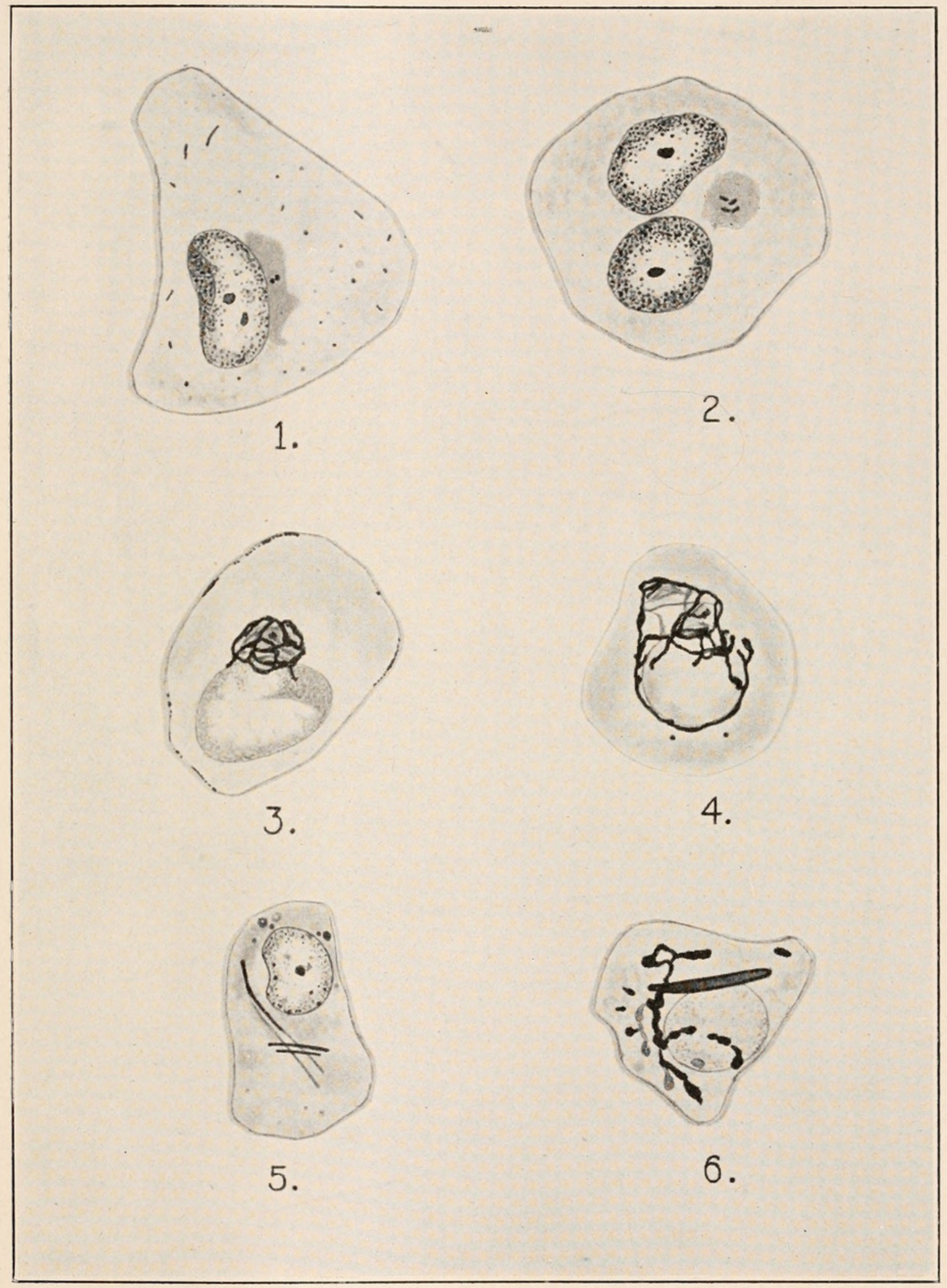

J. DUESBERG. 


7. Binucleated cell with normal chondriosomes. Fixation and stain after Benda.

8. Cell with modified chondriosomes. Same fixation and stain.

9, Io and II. Different types of networks formed of modified chondriosomes. Same fixation and stain.

I2. An interstitial cell with several exogenous processes. Same fixation and stain.

13. A group of interstitial cells, with intracellular and intercellular accumulation of secretion-product. The capillary, filled with the same product, extends, as the next section shows, up to the point marked $\mathrm{X}$. Same fixation and stain. 

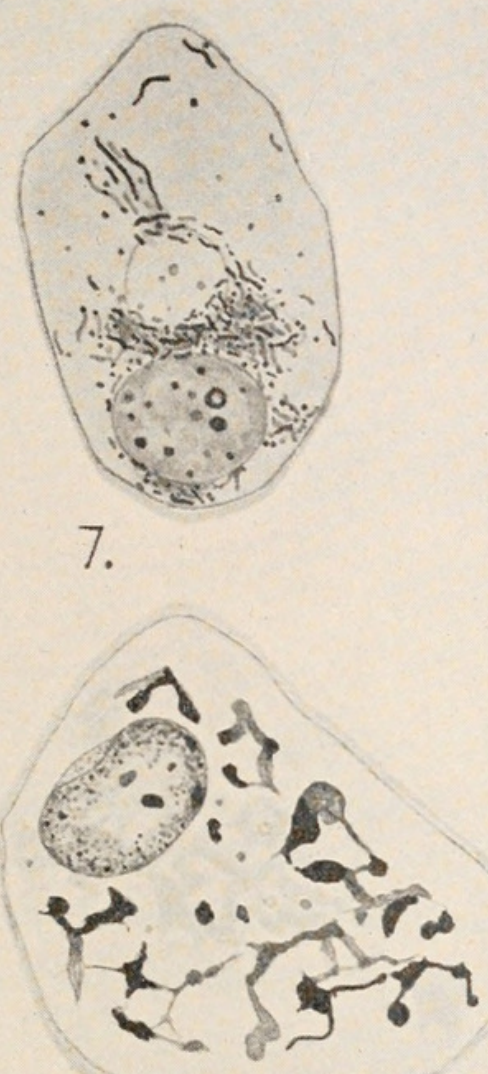

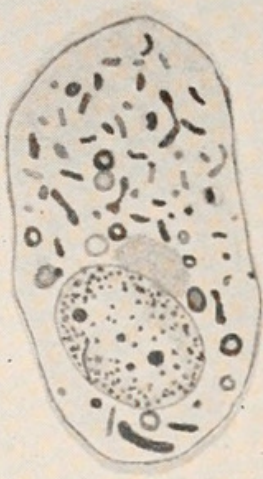

8.
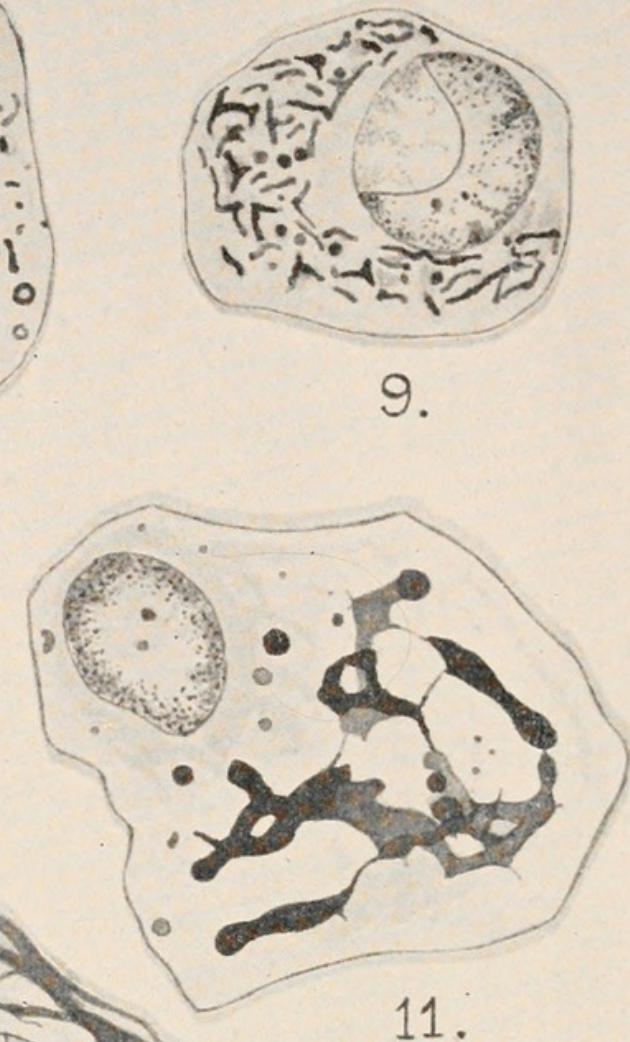

10.

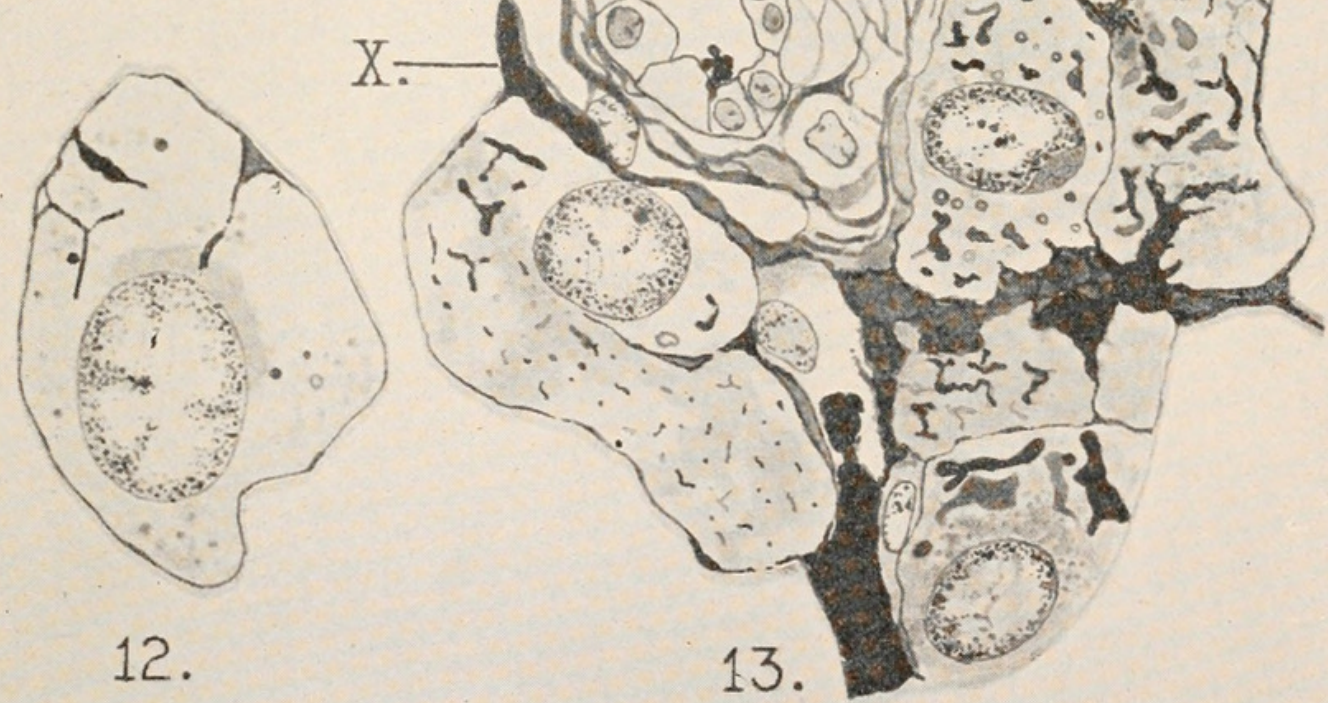

J. DUESBERG. 



\title{
BIOLOGICAL BULLETIN
}

\section{TWO NEW EYE COLORS IN THE THIRD CHROMO- SOME OF DROSOPHILA MELANOGASTER.}

\author{
MILDRED HOGE RICHARDS, \\ CRAWFORDSVILle, INDIANA.
}

In the cultures of Drosophila melanogaster which I have been breeding at Indiana University, two new eye colors have lately appeared. One of these, rose, closely resembles pink and peach of the third chromosome, and is allelomorphic to them. The other eye color, scarlet, is a bright red much like the vermilion of the first chromosome in appearance, but quite distinct from it genetically, for it is located on the third chromosome.

Both eye color mutations occurred in the winter of I9I6. Scarlet appeared (November I8, I9I6) in a wild stock which was being used in a temperature experiment. Rose appeared (January 9, I9I7) after scarlet had been crossed to eyeless, and later was found in the eyeless stock, so that the mutation evidently had occurred there.

A series of temperature experiments was undertaken in the fall of I9I6 in the effort to determine whether it would be possible to adjust a strain of Drosophila to a temperature abnormally high for that species. The flies were bred in pairs, the temperature of the incubator usually being maintained at $27-3 \mathrm{I}^{\circ}$. Each generation of flies was raised, during the greater part of its period of development, at this higher temperature. The flies would not lay, however, under the abnormal conditions; they were allowed to mate, therefore, at room temperature, after which they were transferred to the incubator. The larvæ having pupated, the cultures were again removed from the incubator, for the heat proved fatal to the pupa stages. Even with these 
precautions all of the flies died if the temperature was allowed to rise above $33^{\circ}$.

Although from the standpoint of its original purpose the experiment, due to inadequate apparatus, was not entirely successful, a number of interesting things resulted from it. Abnormalities of various kinds appeared in the second generation of incubated flies. In one case, after the first generation had been developed in the incubator, some of the progeny $\left(F_{1}\right)$ were bred at room temperature, and among the $\mathrm{F}_{2}$ so obtained arose the scarlet eye color.

The temperature experiments were carried on for seven generations; and in each variations appeared. Most of these were peculiarities of the wings, but there were also modifications of eye and leg characters. Among the wing peculiarities were the following: short wings, wing edges turned up, wings folded at the tip, wings bent at abnormal angles, wings spread similar to "spread" of the third chromosome, and wings of odd shapes. Still other flies had weak legs, bent between the joints, and one fly had small eyes.

In each case the variant was allowed to mate with a wild fly at room temperature. The $F_{1}$ were divided into two lots, one of which reproduced at room temperature and the other in the incubator. It was hoped in this way to perpetuate the variations, should any of them be germinal. Many of the flies were nonviable or non-fertile, but in those cases where $F_{2}$ were obtained they were usually normal, and the abnormals which did appear were not like those of the original parent.

Only one color variation appeared. It proved to be germinal in character, and has given rise to the strain called scarlet.

Scarlet is a bright color, like the vermilion of the first chromosome, in flies that are newly hatched. As the flies get older the color gradually changes, and in old flies it is almost indistinguishable from the wild red type. In all crosses where scarlet is used it is highly important, therefore, to count the flies immediately after hatching.

Scarlet was crossed with a member of each of the four groups of linked genes in order to determine its linkage. Crosses were made with blood of the first chromosome, with vestigial of the 
second, with sooty of the third, and with eyeless of the fourth. The results of these crosses demonstrated that scarlet is a member of the third group of linked genes. When scarlet was crossed to blood, vestigial, or eyeless, all possible combinations were formed in $\mathrm{F}_{2}$, showing that independent assortment occurs between these genes and scarlet. However, when scarlet was crossed to sooty, no scarlet sooty flies were obtained in $\mathrm{F}_{2}$. The crosses gave the following results:

I. Scarlet $\sigma^{7} \times$ Blood o (first chromosome character).

$\mathrm{F}_{1} \quad$ Wild-type $\circ$, blood $\sigma^{7}$

$$
\mathrm{F}_{2}\left\{\begin{array}{l}
\text { Wild-type } \sigma^{7} \mathrm{~s} \text { and } \text { is } \mathrm{s} 78 \\
\text { Blood } \sigma^{7} \mathrm{~s} \text { and } \text { क s I } 56 \\
\text { Scarlet } \sigma^{7} \mathrm{~s} \text { and of s } 70 \\
\text { Blood scarlet } \sigma^{7} \mathrm{~s} \text { and o s } 50
\end{array}\right.
$$

2. Scarlet $\times$ Vestigial (second chromosome character).

$\mathrm{F}_{1}$ Wild-type

$$
\mathrm{F}_{2}\left\{\begin{array}{l}
\text { Wild-type 3I2 } \\
\text { Vestigial } 93 \\
\text { Scarlet I09 } \\
\text { Vestigial scarlet } 38
\end{array}\right.
$$

This is evidently a $9: 3: 3:$ I ratio.

3. Scarlet $\times$ Sooty (third chromosome character).

$\mathrm{F}_{1}$ Wild-type

$$
\mathrm{F}_{2}\left\{\begin{array}{l}
\text { Wild-type } 6 \text { I I } \\
\text { Scarlet } 265 \\
\text { Sooty } 284 \\
\text { Scarlet sooty o }
\end{array}\right.
$$

4. Scarlet $\times$ Eyeless (fourth chromosome character).

$\mathrm{F}_{1} \quad$ Wild-type

$$
\mathrm{F}_{2}\left\{\begin{array}{l}
\text { Wild-type } \\
\text { Scarlet } \\
\text { Eyeless } \\
\text { Scarlet eyeless }
\end{array}\right.
$$

Among the $\mathrm{F}_{2}$ of this cross appeared the new eye color which has given rise to the strain called rose. This new eye color was later found in the eyeless stock itself.

The exact linkage relations of scarlet were next determined by mating scarlet to sooty and to dichæte, and back crossing the 
$F_{1}$. Genes for these two characters are located quite far apart in the third chromosome.

Scarlet $X$ sooty

$\mathrm{F}_{1}$ Wild-type

$\mathrm{F}_{1}$ o back crossed to scarlet sooty $0^{x}$ gave the following:

$$
\begin{aligned}
& \text { non cross overs }\left\{\begin{array}{l}
\text { Scarlet I } 230 \\
\text { Sooty I } 5 \text { I I }
\end{array}\right. \\
& \mathrm{F}_{2} \quad \text { cross overs }\left\{\begin{array}{l}
\text { Wild-type } 695 \\
\text { Scarlet sooty } 623
\end{array}\right.
\end{aligned}
$$

Percentage of crossing over was 32.4

Dichæte $\times$ scarlet. Dichæte is a dominant character, nonviable in the homozygous condition. The dichæte to which scarlet was crossed was therefore heterozygous. The $F_{1}$ dichæte females were back crossed to scarlet males and the percentage of crossing over thus immediately obtained in the $\mathrm{F}_{2}$.

$$
\begin{gathered}
\text { Non cross over classes }\left\{\begin{array}{l}
\text { Scarlet } 78 \mathrm{I} \\
\text { Dichæte } 95^{2}
\end{array}\right. \\
\text { Cross over classes }\left\{\begin{array}{l}
\text { Scarlet dichæte } 23 \\
\text { Wild-type } 45
\end{array}\right.
\end{gathered}
$$

Percentage of crossing over is therefore 3.2 .

Scarlet is thus placed at a locus of 3.2 from dichæte, and 32.4 from sooty.

According to unpublished work from the laboratory at Columbia University, the approximate loci for these third chromosome genes are the following:

\section{Dichæte I I \\ Pink and peach I6 \\ Sooty 34}

Since such a large per cent. of cross over was obtained for scarlet sooty (32.4), scarlet is probably at the left of dichæte (on the sepia side), sepia being at 0 . Since it is 3.2 from dichæte, it is at the approximate locus of 7.8 , ( I I -3.2 ).

Since dichæte is 23 to the left of sooty, $(34-$ II $)$, we should expect the value of scarlet sooty to be $3.2+23$ or 26.2 , instead of 32.4. The larger value obtained in this work may have been due of one of several causes. Genetic factors which influence the amount of crossing over have been found by Sturtevant and Muller for the third chromosome group. Plough has also 
shown that in some cases external conditions (temperature) change the amount of crossing over.

Since the appearance of scarlet, the same mutation has been found at Columbia University by D. E. Lancefield. Lancefield's paper will be found in this journal. The two strains arose quite independently, in laboratories remote from each other, and in stocks that were absolutely distinct. They are identical in appearance and in genetic constitution, and are due to the mutation of the same gene, but the process of mutation occurred at different times and in different localities. That they are due to mutation of the same gene is demonstrated by crossing the two stocks together, as I have done, using the stock kindly sent me from Columbia and my own strain. The $F_{1}$ flies from this cross were exactly like the parents. This origin of the same mutation in two widely separated laboratories is of particular interest, for here there is no possibility of contamination.

The mutation rose occurred in the eyeless stock, but was not observed until eyeless was crossed with scarlet. In color rose, which is somewhat lighter than pink, is a shade lighter than peach in older flies, but is practically identical with the latter at the time of hatching. When rose was first observed there was no peach stock kept in the laboratory. The three colors are very similar when the flies are first hatched, but rose does not become as dark with age as do the others.

At the time when rose appeared, Dr. F. Payne had running in the same laboratory stock of a new eye color identical in appearance with rose. At that time it was thought that rose had been derived from this stock by contamination. The gene for Dr. Payne's eye color, called salmon, and as yet unreported, had already been located in the sex chromosome. When salmon was crossed with rose, the following results were obtained.

$$
\begin{aligned}
& \text { Cross I. }\left\{\begin{array}{l}
\text { Salmon } \sigma^{7} \times \text { rose } q \\
F_{1} \text { wild-type. }
\end{array}\right. \\
& \text { Cross 2. }\left\{\begin{array}{l}
\text { Rose } \sigma^{7} \times \text { salmon } q \\
F_{1} \text { Salmon } \sigma^{7} \text { and wild-type } o
\end{array}\right.
\end{aligned}
$$

These results indicated at once that the two eye colors are not the same genetically, since rose is not sex linked. The $F_{1}$ when inbred produced only the two eye colors, wild-type and salmon 
(or rose). Since rose and salmon are indistinguishable phenotypes, the results correspond closely with the expectation as will be seen in the following table. In these results the classes rose, salmon, and the double recessive rose salmon are all alike in appearance and therefore could not be separated.

\begin{tabular}{|c|c|c|c|c|c|}
\hline ' & Classes Expected. 1 & Percentage & Expected. & $\begin{array}{l}\text { Percentage Ob- } \\
\text { tained. }\end{array}$ & $\begin{array}{l}\text { Ac:ual Numbers } \\
\text { Obtained. }\end{array}$ \\
\hline Rose & 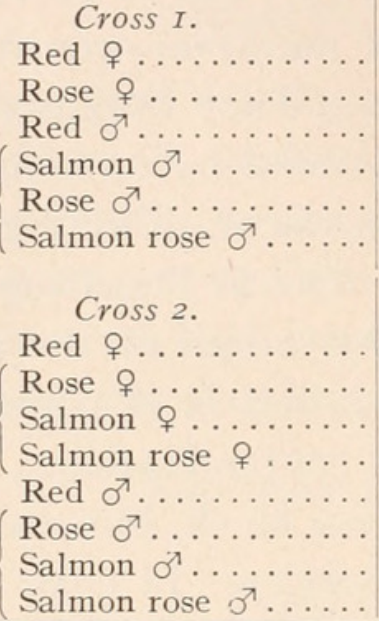 & $\left.\begin{array}{r}6.2 \\
\text { I8.8 } \\
6.2\end{array}\right)$ & $\begin{array}{l}\text { I } 8.8 \\
3 \mathrm{I} .2 \\
\text { I } 8.8 \\
3 \mathrm{I} .2\end{array}$ & $\begin{array}{l}20.9 \\
31.4 \\
17.7 \\
30.0\end{array}$ & $\begin{array}{l}322 \\
483 \\
273\end{array}$ \\
\hline
\end{tabular}

This is another case similar to the well known one of the white sweet peas, in which two different genes produce the same phenotype.

Since rose was not linked to the first chromosome group, it was crossed to vestigial of the second, and to sooty of the third group. The first cross gave a $9: 3: 3:$ I ratio, and the second a 2 : I : I ratio, as follows:

Rose $X$ vestigial

$\mathrm{F}_{1}$ Wild-type

$\mathrm{F}_{2}$ Wild-type I046, vestigial 257, rose 345 , vestigial rose I04.

Rose $\times$ sooty

$\mathrm{F}_{1}$ Wild-type

$\mathrm{F}_{2}$ Wild-type 727 , rose 278 , sooty 330 , rose sooty 0 .

These results show that there is free interchange between the genes for rose and for vestigial, but that rose and sooty are in the same chromosome pair. Rose is therefore a member of the third chromosome group. Its linkage relations were determined

${ }^{1}$ Expectation is calculated by the checkerboard method, on the basis of $\mathrm{I}_{6} \mathrm{~F}_{2}$ individuals. 
by mating the $F_{1}$ female from the cross sooty $X$ rose, to a rose sooty male fly. The $F_{1}$ female was used instead of the $F_{1}$ male for the reason that there is no crossing over in the male of this species. The double recessive rose sooty had been obtained by mating $\mathrm{F}_{2}$ sooty by $\mathrm{F}_{2}$ rose flies. The percentage of cross over from the back cross was $2 \mathrm{I}$.I. This therefore is the strength of the linkage between sooty and rose.

$$
\begin{array}{r}
\text { Non cross overs }\left\{\begin{array}{l}
\text { Rose } 647 \\
\text { Sooty } 634
\end{array}\right. \\
\text { F Cross overs }\left\{\begin{array}{l}
\text { Rose sooty I } 73 \\
\text { Wild-type I } 70
\end{array}\right.
\end{array}
$$

Percentage of cross over, 2I.I.

Rose was next crossed to pink, a third chromosome character of known linkage and with locus $\mathbf{r} 6$. The $\mathrm{F}_{1}$ were intermediate between the two parents, and when inbred gave only $\mathrm{F}_{2}$ of the same eye colors. This showed conclusively that pink and rose are allelomorphic.

The linkage relations of rose should of necessity be the same as those of pink. According to previous work pink had been placed at a distance of about $\mathrm{I} 8$ units from sooty, whereas the present data indicate a distance of 2 I.I units between these factors. This small difference in the percentage of crossing over may be due to one of a number of causes.

Another allelomorph of pink, peach, had previously been identified. When peach is crossed to rose, flies with intermediate eyes resulted. Rose is therefore the third of a series of allelomorphs at the approximate locus of I6 on the third chromosome.

\section{SumMary.}

In a series of temperature experiments, during which cultures of Drosophila melanogaster were incubated, many new variations appeared. Only one, scarlet eye color, similar in appearance to "vermilion" of the first chromosome group, was found to be a true mutation. Scarlet is a third chromosome character whose gene is on the sepia side of dichæte at a locus of 3.2 from the latter. The same eye color has arisen as an independent mutation at Columbia University in the cultures of D. E. Lancefield, whose paper is also in this journal. When crossed, the two strains give $\mathrm{F}_{1}$ like the parents. 
Rose, an eye color appearing in another stock, is the third of a series of allelomorphs. It occupies the same locus on the third chromosome as do pink and peach. Rose is identical in appearance with salmon, a new sex linked mutant found by Dr. F. Payne. This case furnishes another example of different genes producing the same phenotype.

June, I9I8.

Bridges, C. B.

REFERENCES.

'I5 Jour. Exp. Zoölogy, Vol. I9.

Muller, H. J.

'I6 Amer. Naturalist, Vol. 50.

Plough, H. H.

'I7 Jour. Exp. Zoölogy, Vol. 24.

Sturtevant, A. H.

'I7 Proc. Nat. Acad. of Sciences, Vol. 3. 
SCARLET, AN AUTOSOMAL EYE COLOR IDENTICAL WITH SEX-LINKED VERMILION.

D. E. LANCEFIELD,

Columbia University.

Vermilion, a sex-linked eye color in Drosophila melanogaster (ampelophila), is duplicated in appearance by a new mutant called scarlet (symbol $\mathrm{s}_{\mathrm{t}}$ ). The gene for scarlet is located in the third chromosome to the left of dichæte. In spite of this difference of location of the genes for the two eye colors they are quite indistinguishable in appearance and can not be separated from each other when mixed. Here we have a case in Drosophila like the well-known case of the two whites in sweet peas.

Upon crossing scarlet and vermilion, wild-type red is produced. Reciprocal crosses between scarlet and vermilion cut-winged flies from stock gave the following results in $F_{1}$. A vermilion cut male mated to a scarlet female produced offspring entirely wild-type in appearance both for eyes and wings. Reciprocally a scarlet male by a vermilion cut female gave wild-type daughters, while the sons showed the sex-linked characteristics of the mother, viz., vermilion eyes and cut wings.

The next generation was not obtained because the writer entered military service before completing it, but the significant fact is demonstrated already that in Drosophila as elsewhere, indistinguishable characters may be produced by differently located genes.

\section{Origin of Scarlet and Pinkoid.}

The origin of scarlet was rather remarkable as it first appeared in a strain which already contained eosin, and at the same time was found a new eye color, pinkoid, whose gene is in the second chromosome. In a cross of a bar male to an eosin miniature female of non-disjunctional stock, there appeared in the offspring 38 females which were normal in appearance and did not have the heterozygous bar eye. These females were due to reversion 
of the bar gene. One of these females, which was heterozygous for eosin and miniature, was crossed to an eosin miniature brother. The offspring showed no bar, but the eosin flies were very variable, some appearing darker than usual and some lighter like eosin. This was probably totally unrelated to the reversion of the bar factor, for the next generation, produced from eosin flies of the above mating, showed unexpected results. A great variety of eye colors were present. Two of these were the two new mutants found March I8, I9I8 and the other colors were different combinations with eosin. The scarlet individuals were thought to be vermilion until the gene was found to be not sex-linked. The pinkoid flies had an eye-color very closely resembling that of the mutant race known as pink, but had the further interesting characteristic that the wings were also very greatly affected, resembling typically the wings of the "inflated" stock, which is sex-linked. When the eyes were pinkoid the wings were always abnormal, being either inflated as if by a bubble of air or else being shortened and wrinkled. That both the eye-color and the wing character are the result of the same gene is probable because they appeared at the same time in the same individuals and all efforts to obtain the eye-color separate by outcrossing and back crossing have failed.

Owing to the circumstances surrounding the appearance of these two mutants, nothing can be said concerning the stock from which they arose. When first observed, eosin was also present and altogether a most remarkable array of colors was produced. The homozygous form of either new mutant with eosin is white in appearance. The colors ranged from this multiple white up through cream, lemon, eosin, orange, pinkoid to normal red; according to the combination existing in any one individual.

\section{Location of New Genes.}

Pinkoid and scarlet were not sex-linked and were found to be freely segregating from each other. Such segregations indicated that they were in separate autosomes. Accordingly they were each crossed to the double dominant form star dichæte, the genes of which are in the second and third chromosomes respectively. A star dichæte male resulting from these crosses was 
then back crossed either to pinkoid or scarlet stock, as the case might be. Males were used thus because there is no crossing over in males in melanogaster. Pinkoid was found to be a second chromosome gene as no star fly was pinkoid but all not-star individuals were pinkoid without regard to whether or not they were also dichæte. The pinkoid strain had a very low viability, however, and was hard to keep going, so that it is not a satisfactory character for use in genetic experiments. The strain died out while efforts were being made to place the gene in the second chromosome by its linkage to other second chromosome genes.

By a similar cross, scarlet was found to be in the third chromosome; as a star dichæte male, heterozygous for scarlet, back crossed to a scarlet female produced dichæte flies which were never scarlet, and not-dichæte flies which were always scarlet.

Further tests were made to dichæte and to hairless in the third chromosome by crossing scarlet to each and back crossing the heterozygous hairless or dichæte females to pure scarlet males. The results indicated that scarlet is to the left of dichæte in the chromosome, though more extensive data should be obtained. The counts from three cultures gave 534 non-crossovers and I 5 crossovers between dichæte and scarlet, or a percentage of crossing-over of 2.7. Three cultures to test linkage to hairless produced a total of $55^{2}$ flies of which I 40 were in crossover classes, which gives a crossover value of 25.4 per cent. According to unpublished data of Bridges and Gowen the crossover percentage of dichæte and hairless is I8.6. The data here recorded indicate that scarlet is to the left of dichæte, as scarlet gave a crossover value of 25.4 from hairless and scarlet is not far enough from dichæte to be to the right of hairless. However, the relative order of scarlet and dichæte can be definitely settled by more data and by using scarlet with two loci of known position simultaneously.

\section{SUMmary.}

I. Scarlet is a new eye color identical in appearance with vermilion but in the third chromosome.

2. When scarlet is crossed to vermilion, normal red eyes result, except where sons inherit vermilion from their mother. 
D. E. LANCEFIELD.

3. Scarlet gives a crossover percentage of 2.7 with dichæte and 25.4 with hairless.

4. Pinkoid is a new second chromosome mutant that appeared contemporaneously with scarlet, and that affects both the color of the eye and the shape of the wings.

Columbia University,

May, I9I8. 
THE TOXIC ACTION OF KCN AND ITS RELATION TO THE STATE OF NUTRITION AND AGE OF THE CELL AS SHOWN BY PARAMECIUM AND DIDINIUM. ${ }^{1}$

\author{
BARBARA LEE LUND.
}

INTRODUCTION.

Many results from studies on behavior and inheritance in the unicellular organisms show that the same cell is different at different times. The precise conditions under which these differences arise have been only incompletely determined, and in relatively few instances do we know enough about the conditions of their occurrence to be able to repeat exactly the results. In short, physiology knows that differences of this or that kind occur among cells of the same cell species $(i . e$., cells which are apparently identical in outward appearances and history), but knows very little about how they occur and what the changes are in the cell that cause difference in response to identical external conditions at different times.

One of the striking instances of this variability is commonly observed when individuals from a pure line of Paramecium or other protozoa are taken from the same culture and placed in solutions of various kinds of chemicals. Some of the cells die quickly, others survive for long periods of time. What are the origin and causes of such differences among individuals of a pure line population? The following is an attempt to solve some of the features of this problem. ${ }^{2}$ In order to increase the general significance of the results the experiments have been carried out on Didinium nasutum as well as on Paramecium caudatum. Preliminary experiments on Paramecium indicated that the state of nutrition played an important rôle in determining the results, so that Didinium was selected because its food (Paramecium)

${ }^{1}$ From the Department of Animal Biology of the University of Minnesota.

${ }^{2}$ For discussion of certain phases of this problem, see Jennings, "Behavior of the Lower Organisms," Chap. XVI. 
can be controlled both as to quality (a pure line of Paramecium) and as to quantity if necessary. Later it was discovered that an equally good control of the food of Paramecium could be obtained by feeding yeast. A special study of the possibilities and limits of the use of pure yeast as a food for Paramecium is in progress.

The problem of the cause of the differences in resistance to the toxic action of potassium cyanide which Paramecium and Didinium individuals show was chosen because it has very generally been assumed that the toxic action of the cyanides on other organisms is specifically due to their ability to inhibit intracellular oxidations, and that differences in survival time in cyanide solutions were directly due to the difference in the rate of oxidations; or, as more generally expressed, "rate of metabolism" in the organisms studied (Child, 'I5). Does difference in resistance of Paramecia or Didinia to $\mathrm{KCN}$ depend upon the rate of oxidations in the cell?

The variety of types of cell suitable for studies on cell individuals under normal conditions is very limited. Most of the information along this line has been obtained from blood cells, yeast cells, echinoderm eggs and protozoa. The most extensive and accurate physiological data on such questions as the nature of the toxic action of the cyanides, rate of intracellular oxidations and its changes in the cell during the period of cell division and during the time between successive cell divisions, etc., have been obtained from experiments on echinoderm eggs. It is interesting therefore to see to what extent a comparison can be made of the results on echinoderm eggs with those on unicellular organisms during division and the changes which occur in a protozoan cell between two successive divisions. For this reason I have given below a brief review of the literature on the changes that occur in the echinoderm egg during cleavage.

It is important to note that the following results on survival time in the solutions of $\mathrm{KCN}$ were obtained not by observing large numbers of cells at a time, as is usual in this type of experiment, but instead by observing one or two individuals at a time and recording the survival time of each individual, so that the averages given are averages of the survival times of indi- 
vidual cells with a definitely known history. This necessitated a great deal more labor, but was necessary in order to know exactly the age and history of each cell that was used.

\section{EXPERIMENTAL.}

The first two experiments were preliminary and served to orient the problem.

Experiment I.- Suspecting that starvation of Paramecia had some relation to its power of survival in $\mathrm{KCN}$ solutions, a quantity of Paramecia from a pure line hay infusion culture was centrifuged and placed in one half native medium and one half tap water. This was used as a control. Twenty c.c. of this was added to a jar containing 600 c.c. tap water, on March I8; and the same to another jar, on March I9. I made no counts, but there were not over seven or eight hundred animals in each jar, so that there was a large volume for each individual. Fortythree of the control animals were tested immediately with the $\mathrm{KCN}$. About twenty of those added to the pure tap water were tested as soon as added, and about the same number on each successive day following. The animal to be tested was transferred from the tap water to about 2 c.c. $N / 50 \mathrm{KCN}$ solution in a watch glass by means of a capillary pipette. As small an amount of water as possible was transferred with the animal. It was then watched, a binocular microscope being used, until all movement ceased, cessation of movement being considered the death point. Soon after this, as a rule, the animal completely disintegrated. The average time of survival is given in Table I.

As can be seen by glancing at the table the survival time varies greatly in both lots, and apparently chaotically. The standard deviation ${ }^{1}$ each day was large, varying from $0.63 \pm .06$, lot I., for the sixth day to $2.73 \pm .24$ on the fourth day; and similarly for lot II. This did not decrease as time went on.

Before proceeding further, the question arose as to whether the time of beginning cytolysis might be a more unvarying death point than the time of cessation of movement. If the animals are in the same condition as regards food and age then the death

1 The standard deviation is a measure of the degree of variation. See C. B. Davenport, "Handbook of Statistical Methods." 


\section{TABLE I.}

Several hundred paramecia were transferred from a pure line mass culture to each of two jars of tap water, and about twenty of these animals were taken at random each day and treated with $\mathrm{KCN}$. The averages of these survival times is given in the vertical column headed "Average survival time in minutes." The average of the survival times of 43 control individuals from the hay infusion was 2.I9 minutes.

\begin{tabular}{|c|c|c|c|c|c|c|}
\hline & \multicolumn{3}{|c|}{ Lot I, March 18.} & \multicolumn{3}{|c|}{ Lot II, March 19.} \\
\hline & $\begin{array}{l}\text { Number } \\
\text { Tested. }\end{array}$ & $\begin{array}{c}\text { Average } \\
\text { Survival } \\
\text { Time in } \\
\text { Minutes. }\end{array}$ & $\begin{array}{l}\text { Standard } \\
\text { Deviation. }\end{array}$ & $\begin{array}{l}\text { Number } \\
\text { Tested. }\end{array}$ & $\begin{array}{l}\text { Average } \\
\text { Survival } \\
\text { Time in } \\
\text { Minutes. }\end{array}$ & $\begin{array}{c}\text { Standard } \\
\text { Deviation. }\end{array}$ \\
\hline 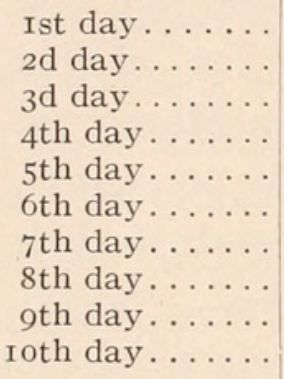 & $\begin{array}{l}23 \\
25 \\
25 \\
28 \\
22 \\
22 \\
22 \\
21 \\
19 \\
20\end{array}$ & $\begin{array}{l}3.289 \\
\text { I.I00 } \\
\text { I.I32 } \\
\text { I.083 } \\
3.190 \\
\text { I.675 } \\
\text { I. } 279 \\
0.966 \\
\text { I.I } 57 \\
\text { I. } 257\end{array}$ & $\begin{array}{l}\text { I.II } \pm . I I \\
0.72 \pm .06 \\
\text { I.09 } \pm .10 \\
2.73 \pm .24 \\
0.94 \pm .09 \\
0.63 \pm .06\end{array}$ & $\begin{array}{l}2 \mathrm{I} \\
22 \\
24 \\
20 \\
20 \\
2 \mathrm{I} \\
20\end{array}$ & $\begin{array}{l}\text { I. } 995 \\
0.870 \\
\text { I. } 595 \\
0.717 \\
\text { I. } 877 \\
0.954 \\
0.902\end{array}$ & $\begin{array}{l}0.76 \pm .07 \\
0.64 \pm .06 \\
\text { I.25 } 2.12 \\
\text { I.54 } 2.16 \\
\text { I.I } 5 \pm .12 \\
0.65 \pm .06\end{array}$ \\
\hline
\end{tabular}

point which is the most constant should be user. I obtained dividing animals in the usual way (described below) and used the daughter cells as soon as division had taken place. Thus the animals were all the same age. The two sisters were placed in a watch crystal with I c.c. $N / 75 \mathrm{KCN}$ solution, and the time of cessation of movement recorded. They were further watched and the time of beginning cytolysis recorded. Two experiments were carried out, 30 animals being tested in the first and 60 in the second. In order to obviate giving all the detailed data the standard deviation, which is a measure of the degree of variation, is given. In the first experiment the standard deviation for the cessation of movement was found to be $2.74 \pm .23$, while for cytolysis it was $3.86 \pm .33$. In the second the figures were $1.08 \pm .06$ for cessation of movement, and $2.37 \pm .13$ for cytolysis. Thus it is seen that the time of cessation of movement in $\mathrm{KCN}$ is less variable, and throughout this work I have used it as the "death point."

Experiment II.-Since the animals in experiment I. were taken at random from a pure line mass culture it is apparent that (I) some of them must have been old and some of them young; 
(2) some of them had also probably eaten more recently than others, containing therefore more food in vacuoles. Could these two factors account for the random variation from day to day, and the deviation in each day's experiment?

To answer this question I first attempted to see whether there was any difference in the survival time between old and young Paramecia when they were treated with $N / 85 \mathrm{KCN}$ solution. A pure line of Paramecia was cultivated in Syracuse watch glasses in hay infusion. About eight fresh watch glasses were set and seeded with the same pure line every day so that a constant supply of dividing animals was at hand. The experiment consisted of four parts:

Part I.: The watch glass cultures were looked over and animals with constrictions isolated in watch crystals. As soon as one divided one of the sisters was picked out with a capillary pipette, washed in one c.c. tap water for about thirty seconds, and then placed in $N / 85 \mathrm{KCN}$ solution and the death point noted; while the other sister was left to age in tap water. Thirty pairs were so treated, the older sisters being killed at invervals varying from 25 to 2 I 5 minutes. The average survival time of the older sisters was less than that of the younger sisters.

Part II.: Thinking that the tap water might have something to do with this result I repeated the experiment but eliminated tap water; that is, I diluted the $\mathrm{KCN}$ with distilled water and allowed the sisters to age in native medium (hay infusion). The average survival time of the older sisters was now greater than that of the younger.

Part III.: Is this difference in result observed in parts I. and II. due to the fact that the $\mathrm{KCN}$ was diluted with tap water in one case and with distilled water in the other, or to the fact that the animals aged in tap water in one case and in native hay infusion in the other? To determine this I repeated the experiment using KCN diluted with distilled water, and allowed the animals to age in tap water. The average survival time of the older sisters was again less than that of the younger, as in part I.

Part IV.: I repeated the experiment, using $\mathrm{KCN}$ diluted with tap water, and allowed the animals to age in native hay infusion. The average survival time of the older sisters was greater than that of the younger. These results are summarized in Table II. 
Conclusion: The older animals are evidently more resistant to $\mathrm{KCN}$ than the younger, and the apparent exceptions shown in parts I. and III. are due to the fact that the animals were left to age in tap water instead of in hay infusion. This was probably due to inanition and not to any deleterious effect of the tap water itself. See experiment VI. below.

\section{TABLE II.}

Summary of Results of Experiment II., Parts I., II., III. And IV.

\begin{tabular}{|c|c|c|c|c|}
\hline & I (3o Pairs). & II (3o Pairs). & III (30 Pairs). & IV (30 Pairs). \\
\hline & $\begin{array}{c}\text { KCN Diluted } \\
\text { with Tap Water. } \\
\text { Animals Left to } \\
\text { Age in Tap } \\
\text { Water. }\end{array}$ & $\begin{array}{l}\text { KCN Diluted } \\
\text { with Distilled } \\
\text { Water. Ani- } \\
\text { mals Left to } \\
\text { Age in Native } \\
\text { Hay Infusion. }\end{array}$ & $\begin{array}{l}\text { KCN Diluted } \\
\text { with Distilled } \\
\text { Water. Ani- } \\
\text { mals Left to Age } \\
\text { in Tap Water. }\end{array}$ & $\begin{array}{l}\text { KCN Diluted } \\
\text { with Tap Water. } \\
\text { Animals Left to } \\
\text { Age in Native } \\
\text { Hay Infusion. }\end{array}$ \\
\hline $\begin{array}{l}\text { Average survival time of } \\
\text { older sisters compared } \\
\text { to younger.......... }\end{array}$ & less & greater & less & greater \\
\hline
\end{tabular}

Experiment III.- In performing the preceding experiments the question arose as to whether the effects of ageing in native medium were cumulative; that is, whether the resistance increased regularly as age advanced. To answer this question the following experiment was performed. The procedure was the same as in experiment II. except that $N_{/ 75} \mathrm{KCN}$ was used. One sister was killed in this immediately after division. The other sister was allowed to grow in the native medium (hay infusion) and killed at ages varying from io to 600 minutes. Thirty Paramecia were tested in each case; that is, thirty "young" and thirty "old" for each time interval. Averages of the survival times for the young and the old for each time interval were made, and in every case the average length of life after treatment with $\mathrm{KCN}$ was greater in the case of the old than of the young animals.

The results of this experiment are summarized by giving these averages and the difference between them (Table III.). They are plotted in curves (Fig. I).

The difference between the averages increases as age of the surviving sister increases. The degree of variation in survival time is relatively small when compared to the average survival 
time, showing that the results are comparable and real; that is, that there are actual differences in survival time. This indicates so far as this experiment goes that there is an absolute increase in the survival time of the cells in hay infusion from one division to the next division, rather than that the increase is due to decrease in survival time of their sisters killed immediately after division; for the survival time of the latter tended to remain about the same throughout the experiment as shown by the horizontal trend of curve $C$.

\section{TABLE III.}

\section{Paramecium.}

A. Time in minutes between division of Paramecium and the killing of one sister in $N / 75 \mathrm{KCN}$.

$B$ and $C$ are self explanatory, each number representing an average of thirty individuals.

$D$. Average difference in survival time between the paramecia which were killed immediately after dividing and their sisters which were killed at the above intervals after living in native hay infusion. Each number represents the difference between the two preceding numbers in the same column.

\begin{tabular}{|c|c|c|c|c|c|c|c|c|c|c|c|}
\hline $\begin{array}{l}\text { Age of "old" } \\
\text { in mins. . . . }\end{array}$ & $A$ & IO & 20 & 30 & 40 & 60 & I 20 & I 80 & 300 & 480 & 600 \\
\hline $\begin{array}{l}\text { Average survi- } \\
\text { val time in } \\
\text { minutes of } \\
\text { "old" sisters } \\
\text { Average survi- } \\
\text { val time in } \\
\text { minutes, of } \\
\text { "young" } \\
\text { sisters...... }\end{array}$ & $C$ & 2.22 & 2.62 & $3 \cdot 30$ & $3 \cdot 35$ & 2.85 & 2.90 & 3.00 & 2.09 & 2.24 & $3.7 \mathrm{I}$ \\
\hline Difference .... & $D$ &. $\mathrm{I} 3$ & .43 & .40 & $.6 \mathrm{I}$ & .55 & .74 & .93 & 1.02 & I. $3 \mathrm{I}$ & I. 16 \\
\hline $\begin{array}{l}\text { Standard de- } \\
\text { viation of } \\
\text { "old" sisters }\end{array}$ & $F$ & $\begin{array}{r}0.5 \mathrm{I} \\
\pm .04\end{array}$ & $\begin{array}{r}0.34 \\
\pm .03\end{array}$ & $\begin{array}{r}0.36 \\
\pm .03\end{array}$ & $\begin{array}{r}0.72 \\
\pm .06\end{array}$ & $\begin{array}{r}0.64 \\
\pm .06\end{array}$ & $\begin{array}{r}0.47 \\
\pm .05\end{array}$ & $\begin{array}{r}0.48 \\
\pm .05\end{array}$ & $\begin{array}{r}0.40 \\
\pm .04\end{array}$ & $\begin{array}{r}0.85 \\
\pm .07\end{array}$ & $\begin{array}{r}0.67 \\
\pm .07\end{array}$ \\
\hline
\end{tabular}

We may then briefly summarize the results from the previous experiments on Paramecium by saying that these have clearly shown that beginning at division there is an increase in the resistance of Paramecium to $\mathrm{KCN}$ when it is permitted to live in hay infusion, while if placed in tap water the resistance decreases.

By using hay infusion it would be practically impossible to show in Paramecium that these results are due to the state of 


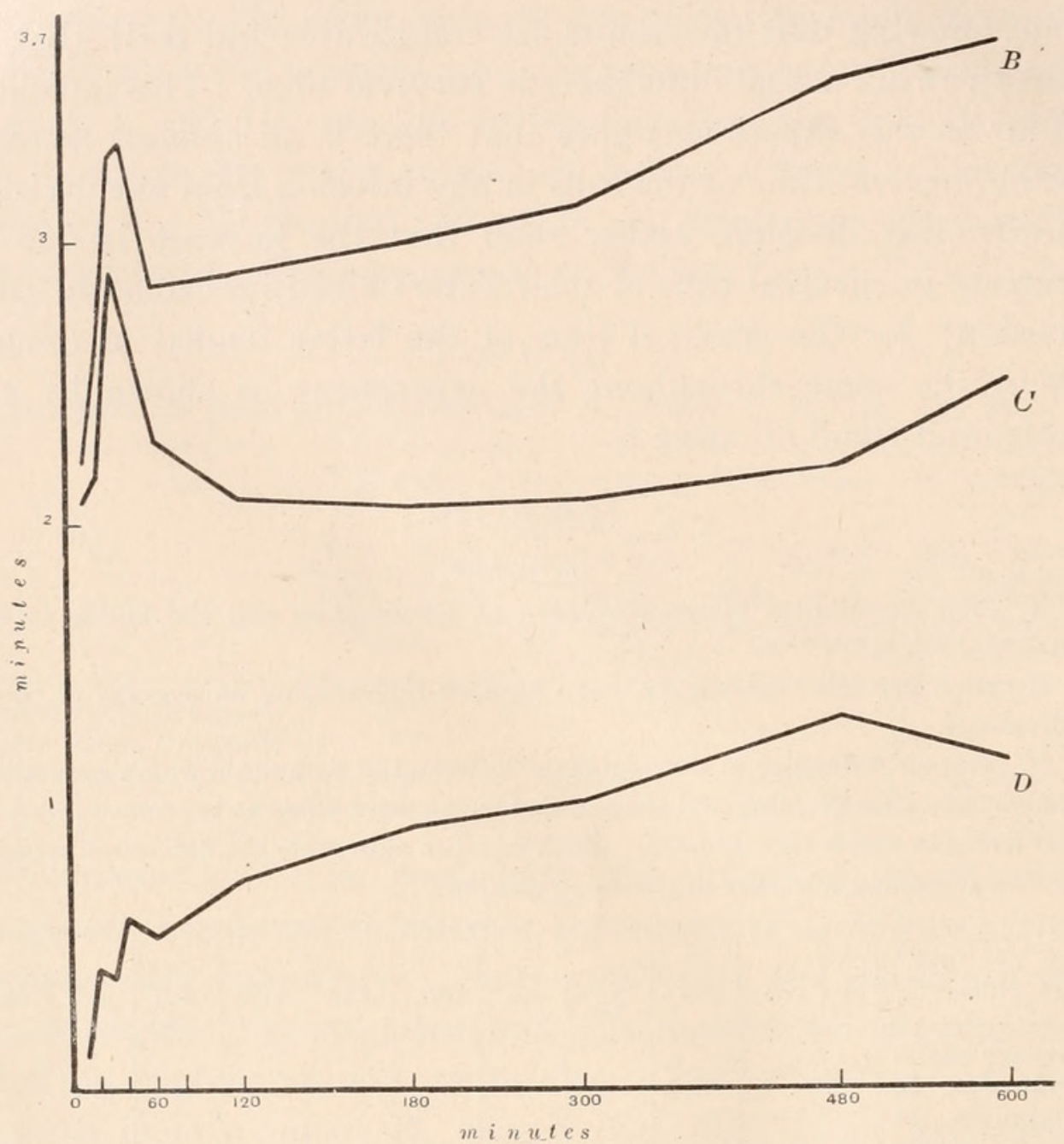

FIG. I. Paramecium. Survival time of "old" and "young" paramecia in KCN. (See Table III.) Curve $B$ represents the average survival time of "old" sisters. Curve $C$ represents the average survival time of the "young" sisters of $B$. Curve $D$ represents the difference between the average survival times of the " old" and "young" sisters. That is, it is the difference between the curves $B$ and $C$. The relatively long survival time at 30 and 40 minutes, curves $A$ and $B$, is due to lower temperature.

nutrition of the cell; for if we wished to show that it was due to the bacteria serving as food it would be necessary to provide the same medium (say, tap water) for both sisters, while only one sister was fed with bacteria. To control the bacterial food of Paramecia is very difficult, hence Didinia were used in the following experiments. A pure line of Paramecia served as food for the Didinia, and since the Paramecia could be washed free from hay infusion and placed in tap water it was possible to have all experimental conditions for the two sister cells of Didinia exactly 
the same, except presence or absence of food. This then supplied ideal conditions for answering the question as to whether the state of nutrition of the cell was the condition which determined the survival time of the cell in $\mathrm{KCN}$.

Experiment $I V$.-Didinia were cultivated in tap water in Syracuse watch glasses and fed on freshly washed Paramecia taken from a pure line mass culture. Animals with constrictions were isolated in watch crystals in tap water, and immediately on separation one sister was transferred to another watch glass in which was about one c.c. tap water containing many Paramecia. The two dishes, one containing one of the pair in tap water, the other containing the other sister in tap water and Paramecia, were then placed side by side in a moist chamber, and later the two sisters were killed at the same time in the same one c.c. of $N / 20 \mathrm{KCN}$ solution. A more concentrated solution of $\mathrm{KCN}$ was used here for convenience, to shorten the survival time, for Didinium is much more resistant to $\mathrm{KCN}$ than Paramecium. Occasionally it was impossible to tell the difference between the two sisters at the end of the desired period, the one placed with Paramecia evidently not having eaten; and in those cases they were killed separately but as near the same time as possible. By working with two binoculars it was possible to make the treatment of the two with $\mathrm{KCN}$ practically simultaneous. Thirty pairs were used in each case, so that sixty individuals were killed at the end of each period of $\mathrm{x} / 2, \mathrm{I}, 2,3,4$ and 5 hours after division. The results are summarized in Table IV., and curves $C, E$ and $D$, Fig. 2 .

The average difference in survival time (row $D$ ) increases until the fourth hour, and in this lot three fed ones out of thirty-three had divided; while in the next lot, that of five hours, 37.5 per cent. or 18 out of the 48 individuals isolated had divided and division of the remainder was apparently not far off. It was impossible to get a record of a six hour lot on account of division. Since the starved individuals did not divide at the same rate as the fed ones, it was possible to continue that part of the experiment beyond five hours. Table IV. B. It will be noted that the average survival time of these starving individuals shows a marked decrease. This is shown in Fig. 2, curve $E$. Is the 


\section{TABLE IV.}

\section{Didinium.}

A. Time after division when the sisters were killed in $N / 20 \mathrm{KCN}$. One of them had been starving in tap water, the other feeding on Paramecia in tap water. The temperature for this experiment was between $23^{\circ}$ and $24^{\circ} \mathrm{C}$. throughout, with the exception of the 12 -hour lot when the temperature went down to $19^{\circ} \mathrm{C}$. This accounts for the longer survival time in that case.

$B$ and $C$ are self explanatory, each number representing an average of 30 individuals.

$D$. Difference between the two preceding figures in the same column. That is, each number represents the average difference between 30 starved and 30 fed Didinia sisters.

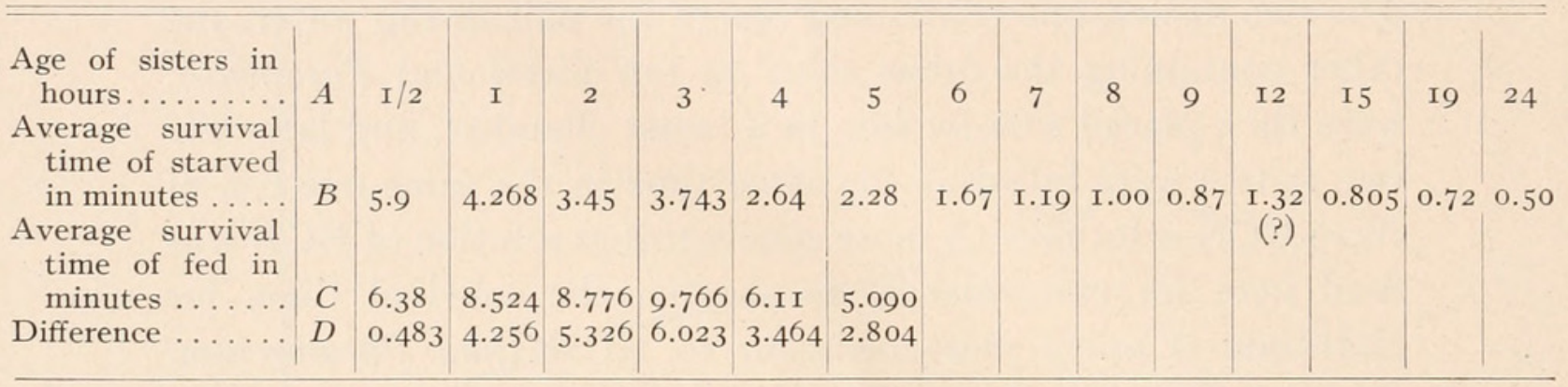

increasing difference (Fig. 2, curve $D$ ) up to the fourth hour due entirely to the fact that one sister has eaten while the other has not; or do the sisters, presumably identical at the time of separation, gradually diverge as a result of differing rates of maturity, apart from effects of nutrition, so that even though subjected to the same conditions they would show different degrees of resistance as time went on?

Experiment V.-To answer this question an experiment was carried out in the usual way, the dividing animals being isolated and killed with KCN. I found, however, that the concentration of KCN I had previously used did not bring out the small differences in survival time as well in this case where the sisters were in the same medium and both were without food, as a weaker solution. Thirty pairs or sixty individuals were killed at the end of each period of $\mathrm{I} / 2, \mathrm{I}, 2,3,4,5,6,7,8,9, \mathrm{I} 2$, I9 and 24 hours after division. Since there was no difference in appearance or in previous treatment of the sisters I arbitrarily placed the survival times of the animals which died first in one column, and that of their more resistant sisters in another, took an average of the thirty individuals in each case, and have given in Table V. 
the average survival times of each and the differences between these averages. The difference is also plotted in Fig. 2, curve $A$.

These results demonstrate that in the same environment the differences in survival time of the sisters do not increase but

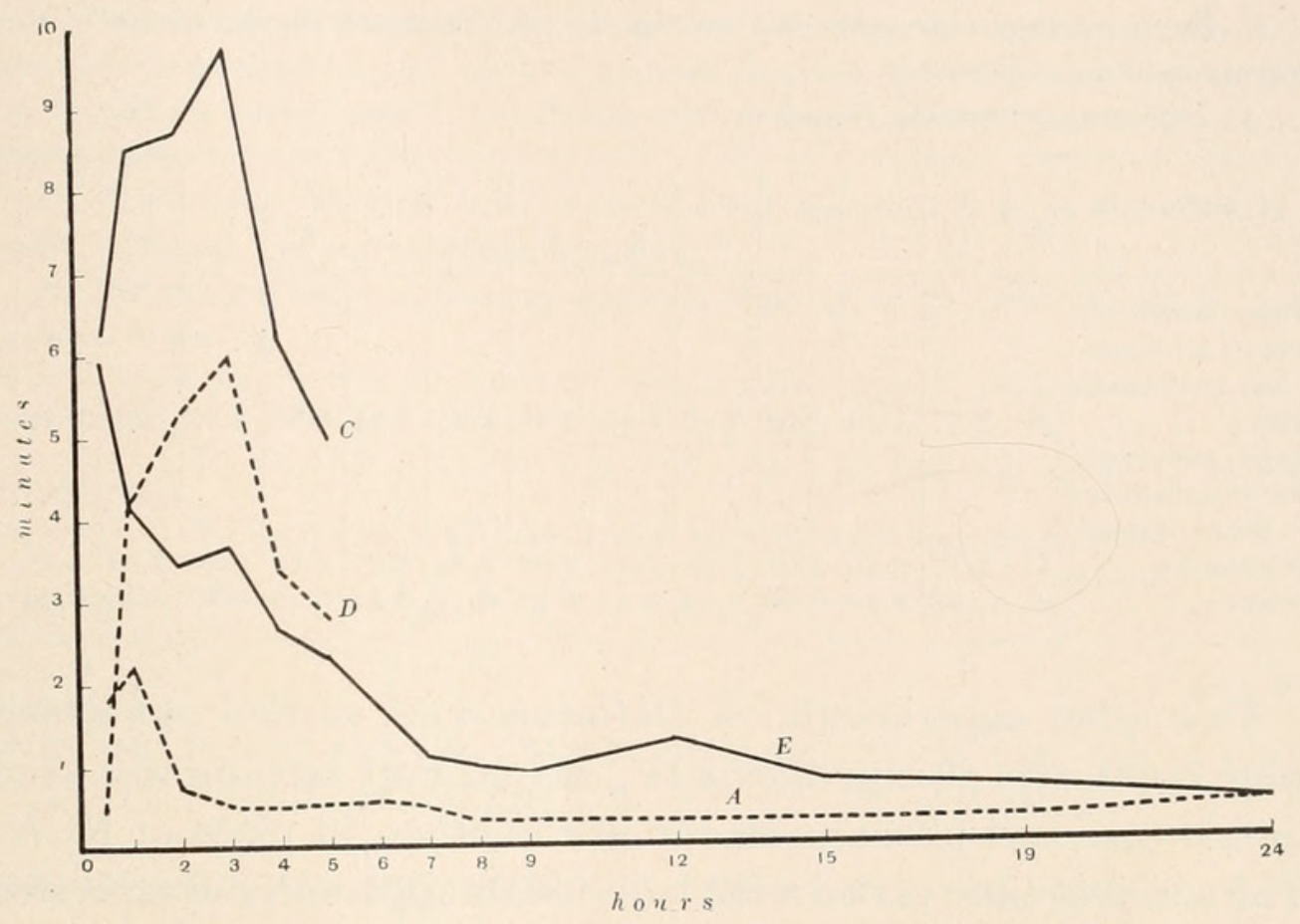

Fig. 2. Didinium. Survival time of Didinia in KCN. Summary of Tables IV. and V. The abscissa represents time in hours between division and death of Didinia. The ordinate represents survival time in minutes. Curve $C$ represents the average survival time of fed Didinia. (See Table IV, C.) Curve $E$ represents the average survival time of the starved sisters of $C$. (See Table IV., E.) Curve $D$ represents the difference between the average survival times of fed and starved sisters. That is, it is the difference between $C$ and $E$. (See Table IV., D.) Curve $A$ represents the difference between the average survival times of the less and more resistant sisters, when both are starved. (See Table V., A.)

if anything decrease with time; $i . e$. , the cells tend to become more alike in their resistance to $\mathrm{KCN}$, and therefore the large difference shown in experiment IV. must be due to the food one has eaten while the other has starved. Table V. shows that the difference in survival time at one half and one hour is greater than at any subsequent time. This is explained by the fact that division in Didinium is often unequal, one sister evidently containing more food in vacuoles than the other. As this food is used up by the cell the difference in survival time becomes less. (See experiment VI. below.) 


\section{TABLE V. \\ Didinium.}

$D$. Time after division at which the sisters, both of which had been subjected to the same treatment, were killed.

$B$. Each number represents the average survival time of 30 Didinia.

$C$. Each number represents the average survival time of the 30 sisters of the corresponding set of row $B$.

$A$. Differences between $B$ and $C$.

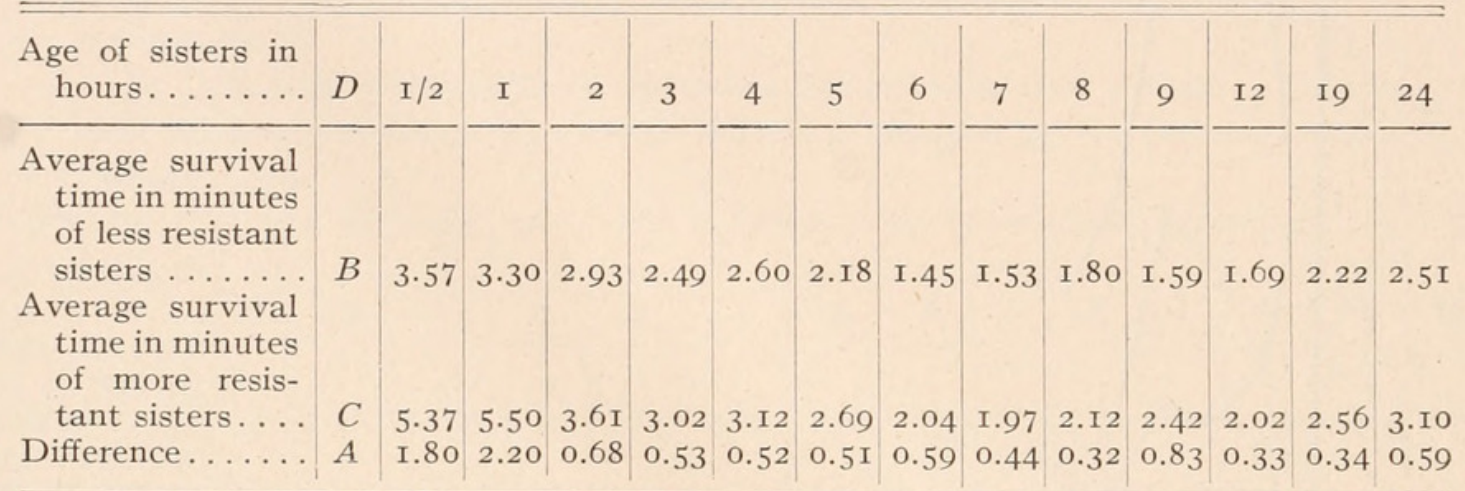

Two other experiments on Didinium were carried out which were duplicates of experiment IV., except that saponin was used in one case and phenylurethane in the other, in place of KCN. The survival time varied with individuals apparently irrespective of the state of nutrition of the cell. The death points were less definite than in the case of $\mathrm{KCN}$, and hence further efforts to trace the causes of difference in survival time in these substances was abandoned for the time being.

Some time after the preceding results were obtained it was found possible to grow pure lines of Paramecia in tap water by feeding them yeast, thereby making it possible to duplicate experiments IV. and V. on Didinium.

Experiment VI.-A pure line of Paramecia was raised in a suspension of fresh yeast and tap water. The Paramecia were centrifuged and washed thoroughly every morning, and added to a new suspension of fresh yeast to continue the culture. The cultures were kept in Syracuse watch glasses. If a culture is neglected and bacteria develop to any extent, the Paramecia become abnormal and finally die. If a starved Paramecium is put into a freshly made yeast suspension it eats greedily, and in a few hours increases greatly in size. From such yeast fed material, animals with constrictions were picked out with a 
TABLE VI.

Paramecia, Yeast-Fed and Starved.

$A$. Time between division and killing the two sisters, one of which had lived in tap water, the other in tap water and fresh yeast suspension.

$B$. The averages of the survival times of 30 fed Paramecia.

$C$. Since all those left with food for I 2 hours divided, the experiment was con-

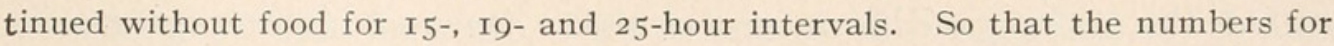
I5, I9 and 25 hours, rows $C$ and $D$ represent average survival time of 30 starved sisters each.

$D$. The average survival time of the starved sisters of $B$ from o to I2 hours and of $C$ from 12 to and including 25 hours.

$E$. Differences between average survival time given in rows $B$ and $D$, and between $C$ and $D$.

\begin{tabular}{|c|c|c|c|c|c|c|c|c|c|c|c|c|c|c|c|}
\hline $\begin{array}{l}\text { Age of sisters in } \\
\text { hours } \ldots \ldots \ldots\end{array}$ & $A$ & 0 & I & 2 & 3 & 4 & 5 & 6 & 7 & 8 & 9 & I 2 & I 5 & I9 & 25 \\
\hline $\begin{array}{c}\text { Average survival } \\
\text { time of fed.... }\end{array}$ & B & 2.42 & 2.64 & 2.58 & 2.52 & $2.5 \mathrm{I}$ & 2.50 & 2.44 & $2.5^{8}$ & 2.43 & 2.75 & $\begin{array}{l}\text { all di- } \\
\text { vided }\end{array}$ & & & \\
\hline $\begin{array}{r}\text { Average survival } \\
\text { time of starved } \\
\text { sisters of } D \ldots \\
\text { Average survival }\end{array}$ & $C$ & & & & & & & & & & & & I.I 3 & I. I 7 & I. \\
\hline $\begin{array}{l}\text { time of starved } \\
\text { Difference...... }\end{array}$ & $\begin{array}{l}D \\
E\end{array}$ & $\begin{array}{r}2.40 \\
.02\end{array}$ & $\begin{array}{r}2.24 \\
.04\end{array}$ & $\begin{array}{r}\mathrm{I} .88 \\
.70\end{array}$ & $\begin{array}{r}1.80 \\
.72\end{array}$ & $\begin{array}{r}1.84 \\
.67\end{array}$ & $\begin{array}{r}\text { I. } 79 \\
.76\end{array}$ & $\begin{array}{r}\text { I. } 74 \\
.70\end{array}$ & $\begin{array}{r}\text { I. } 77 \\
.8 \mathrm{I}\end{array}$ & $\begin{array}{r}\text { I. } 56 \\
.87\end{array}$ & $\begin{array}{r}1.78 \\
.97\end{array}$ & I.59 & $\begin{array}{r}\text { I. I I } \\
.02\end{array}$ & $\begin{array}{r}\text { I.I4 } \\
.03\end{array}$ & I. 05 \\
\hline
\end{tabular}

capillary pipette and placed in tap water. As soon as they separated one was placed in a watch glass of fresh yeast suspension, while the other was left in tap water. Sets of thirty each of such pairs were killed in $N / 75 \mathrm{KCN}$ at intervals of $\mathrm{I}, 2,3,4$, $5,6,7,8$ and 9 hours. It was impossible to continue this experiment longer than nine hours, for a large percentage of those which were fed, divided between the ninth and tenth hour. Sets of starved animals were continued however for 25 hours, being killed at intervals of 12, I5, I9 and 25 hours. The results are summarized in Table VI., and in the curves of Fig. 3.

The difference in survival time shows a general increase up to and including the ninth hour, the animals which were placed in the yeast supsension living longer than their sisters which were placed in clear tap water. The survival time of the latter showed a marked decrease with age. The experiment was continued, but instead of feeding one sister and starving the other, both were starved, as was done with Didinia in experiment $\mathrm{V}$. above. Thirty pairs were left to starve in tap water for each period of I $_{5}$, I9 and 25 hours, and then tested with $\mathrm{KCN}$. I arbitrarily 
placed the survival times of the sisters which died first in one column, and the more resistant sisters in another (though as a rule the survival times of sisters was the same), took an average of the two sets of sister cells of thirty individuals for each period and then found the differences between these averages, which I called the average difference between starved sisters, given in Table VI. E. This difference was very small, being .02, .03, and .02 minutes respectively for 15,19 and 25 hours. This is practically the same as saying that there is no difference, since these numbers are within the limits of error in determining the

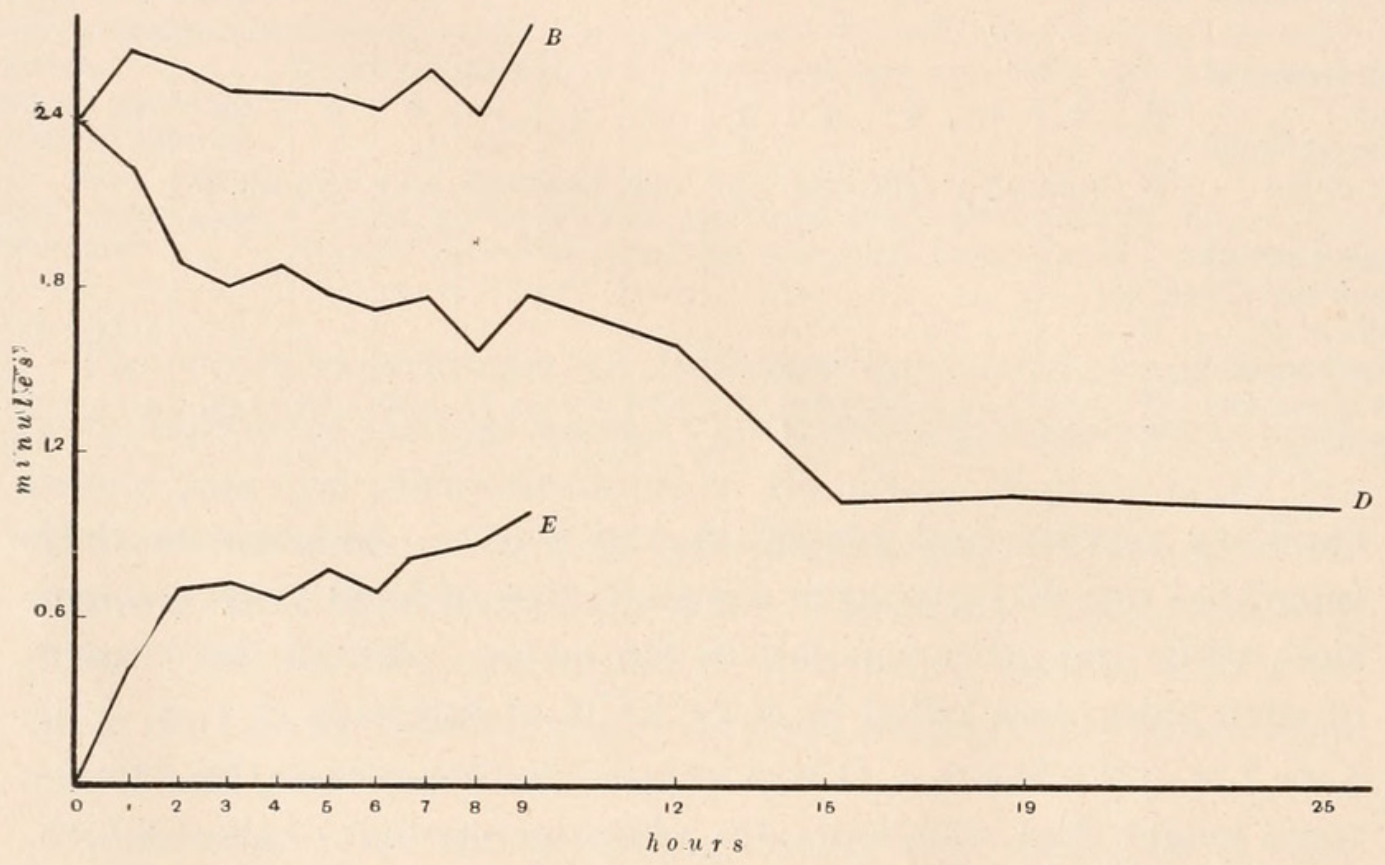

FIG. 3. Paramecium. Survival time of starved and yeast fed Paramecia in KCN. (See Table VI.) The abscissa represents time in hours between division and death of Paramecia. The ordinate represents survival time in minutes. Curve $B$ represents the average survival time of yeast-fed Paramecia. Curve $D$ represents the average survival time of the starved sisters of $B$. Curve $E$ represents the difference between the average survival times of the fed and starved sisters. That is, it is the difference between the curves $B$ and $D$.

death point. It is important to notice that the average difference in survival time of thirty pairs immediately after division, and the average difference after the sisters had been starving 25 hours, are exactly the same (viz., .02 minutes), even though the actual survival time of sisters immediately after division and after starving for 25 hours is very different. This close correspondence is probably due to the fact that in the case of Para- 
mecia division is practically equal; that is, there is as much food in one daughter cell as in the other. While in the case of Didinia we often have unequal division, and accordingly the difference in survival time is greatest at the age of one half and one hour.

Attention may be called to the fact that here the Paramecia which were left to age in tap water and food (that is, yeast) were more resistant than those left in tap water alone, and that therefore the tap water as such had no deleterious effect, as might have been suspected in the case of Paramecia grown in hay infusion. (Cf. experiment II. above.)

\section{Discussion.}

It is evident then from the preceding six experiments that young Paramecia and starved Paramecia are more susceptible to $\mathrm{KCN}$ than old (fed) Paramecia. In the case of Didinia, although as far as average differences are concerned, the reactions of the starved and fed are like that of Paramecia, when the survival times of the fed animals are considered alone, it is seen that there is a decided rhythm, the resistance increasing up to the fourth hour and then decreasing to the sixth hour, at which time a large percentage has divided. In view of this latter fact it is of interest to note the similar results of Lyon and others in regard to the rhythmic susceptibility of sea urchin eggs. The results of Lyon's experiments (Lyon, '02) on the susceptibility of sea urchin eggs to KCN solutions show roughly, although clearly, that the susceptibility to $\mathrm{KCN}$ reaches a maximum and a minimum at stated intervals. About ten to fifteen minutes after fertilization the egg is especially suspectible to KCN. Again, after the first cleavage and after the second come susceptible periods with a rise in resistance in between. He was working on the supposition that KCN inhibits oxidations, and so it would be possible to test this further by depriving the eggs of oxygen in some other way. This he did by substituting hydrogen for air in the water in which the eggs were to develop. There was a decided similarity between this experiment and the previous one. There was a gradual loss of resistance during the first ten to fifteen minutes after fertilization. Then the resistance increased. This experiment was carried no further than thirty 
minutes, and so it is uncertain as to whether there was a second and a third susceptible period after the first and second cleavages. $\mathrm{He}$ also investigated the effect of heat and cold on developing sea urchin eggs (Lyon, 'O4) and found that immediately after the entrance of the sperm the egg is more susceptible to heat than a few minutes later. The resistance decreases, reaching a low point just before division, then increases, reaching a maximum right after division, decreasing again to a low limit just before the second division. Similar experiments were performed with cold but they were not carried beyond the first cleavage, so here no rhythm was demonstrated, but he considers the existence of such a rhythm probable. Lyon ('o4) also studied the carbon dioxide production of the developing sea urchin egg. His experiments here were not strictly quantitative in character, but he found a slight increase in $\mathrm{CO}_{2}$ production in the first ten to fifteen minute interval following fertilization. Decreased $\mathrm{CO}_{2}$ production followed. The interval during which the eggs were actively dividing into the first two blastomeres was one of active $\mathrm{CO}_{2}$ production. This was followed by a period of lessened production with a second rise at the time of the second cleavage. Spaulding ('o4) also found decided rhythms in the resistance of the developing sea urchin egg to both ether and hydrochloric acid. Mathews ('o6) made a study of living eggs of Arbacia and Asterias and examined sections of eggs preserved at definite intervals after fertilization. Comparing Lyon's work on Arbacia and the condition of the egg at the various intervals, as shown by the sections, he concludes that the period of greatest susceptibility is immediately before and during segmentation, and that just after segmentation there is a period of great resistance. He also endeavored to repeat Lyon's work on Arbacia, using Asterias eggs. The results were unsatisfactory so far as sharp and decisive periods of susceptibility were concerned, but they showed clearly that the eggs in certain stages were more susceptible to $\mathrm{KCN}$ than in others.

Moore ('I5), in his work on artificial parthenogenesis, found that the greatest number of eggs, which had been previously treated with butyric acid, developed when treated with the hypertonic sea water at 40,60, 90-I00 and II 5-I25 minutes 
after the fatty acid treatment. In the case of normally fertilized eggs where hypertonic sea water would not have the above "curative" effect, but could be nothing but injurious, he found that with an exposure of 40 minutes a maximum susceptibility occurred just after fertilization and immediately before and during each cytoplasmic division; while maximum resistance is 35 to 45 minutes after fertilization and just after each division. R. S. Lillie ('I6) finds an osmotic swelling taking place in Arbacia eggs when placed in dilute sea water. The rate of this swelling depends upon the degree of dilution of the sea water and the condition of the eggs. The fertilized eggs have a higher resistance to the osmotic swelling, and consequent cytolysis than the unfertilized; but shortly before the appearance of the cleavage furrow the resistance rapidly declines to a minimum at the time of the appearance of the furrow. Immediately after the completion of the furrow the former resistance returns. A similar change is found at the second and third cleavages, and probably occurs at all cell divisions.

In looking for a cause or causes of the variability in resistance of Didinium and Paramecium to $\mathrm{KCN}$ we are reminded at once of the fact that Lyon found the periods of susceptibility to KCN of the sea urchin eggs to correspond to those for hydrogen which might lead to the conclusion that oxidations are interfered with. Warburg ('I4) and Loeb and Wasteneys ('I3) have found that the oxygen consumption of the sea urchin egg is actually decreased by the presence of KCN. Child ('I5) finds that stimulated flat worms are more susceptible to $\mathrm{KCN}$ than the unstimulated, and also that the worms which he found to have a low resistance to $\mathrm{KCN}$ had a high rate of $\mathrm{CO}_{2}$ production as determined by Tashiro's biometer. He concludes from this fact that there is a relation between the resistance to $\mathrm{KCN}$ and "the rate of metabolic reactions, or certain of them, probably the oxidations." He also finds that there is a marked difference between old and young Planaria, and between starved and fed Planaria of the same age. The young worms and the starved worms show a greater degree of susceptibility than the older worms and the well fed worms, respectively. The results given above for Paramecium and Didinium are the same as those found 
by Child on Planaria. Now, considering the parallelism between resistance to $\mathrm{KCN}$ and $\mathrm{CO}_{2}$ production and also the resistance to KCN of stimulated and unstimulated worms, Child concludes that the young worms have a greater metabolic rate than the old ones, the starved greater than the fed; and since my results on Paramecia with respect to survival time in $\mathrm{KCN}$ seem to be identical with these on Planaria, I was inclined to accept this conclusion and apply it to these protozoa. But recent work in this laboratory on the actual oxygen consumption of Paramecia indicates that in the case of this animal at least KCN has no effect on oxidations, even up to concentrations which kill in a few hours (Lund, 'I8). And so we must search for the explanation of these differences in some other direction.

If the permeability of the plasma membrane of the protozoan, like that of the surface of the sea urchin egg, changes at different times in its history and with different nutritive conditions, we might use that in explaining its various reactions to $\mathrm{KCN}$. R. S. Lillie ('I6) has shown that in the case of the egg, permeability is greatest at division and less between divisions; and, as stated above, according to Lyon and others, susceptibility to $\mathrm{KCN}$ is greatest at division and less during the time between divisions. Didinia show a similar behavior, the resistance increasing up to the fourth hour, but then decreasing again to the fifth hour when 37 per cent. of them have divided. The results for Paramecia, however, do not give a curve of this shape; although the resistance increases to a marked extent in hay infusion, and to a smaller extent when fed yeast, up to the very time of the beginning of the formation of the constriction. My data on the reactions beyond this point (that is, the time when the cell begins division) are insufficient to warrant conclusions. However, my impression from the few Paramecia which did happen to be in the beginning stages of division while in the $\mathrm{KCN}$ is that the resistance does not decrease previous to the time of separation.

If, on account of this parallelism with the results on the egg, it is conceded that the susceptibility of Didinia is due to an increase in permeability, the conclusion might be justified that the high susceptibility of the starved animals is due to the same 
thing. If this is the case, it is obvious that there is an inconsistency in relating permeability and rate of oxidations; for the egg at division has an increase in permeability and also, if we may depend upon the limited data available on this point, an increase in oxidation rate, while a starved Paramecium or Didinium has, according to this hypothesis, an increase in permeability and, according to the facts, a decrease in rate of oxidation. The latter has been found in some recent work in this laboratory, which is as yet unpublished.

It is interesting to note, in regard to the lack of resistance to $\mathrm{KCN}$ of the starving cells, that this is in accord with the common experience that tissues suffering from lack of normal blood supply offer less resistance to various toxins and infections than tissues which are well supplied with blood; $i . e .$, well nourished.

It is evident that the experiments given above on Paramecium and Didinium, and the results on eggs of echinoderms by others, and those on lower invertebrates, offer a promising avenue of approach to an understanding of what some of the fundamental conditions in the cell are which determine the degree of resistance of cells to toxic substances.

\section{SUMMARY.}

I. An attempt was made to discover what factor or factors are responsible for the observed differences among individuals of a pure line of Paramecia and Didinia living in the same culture medium; e.g., hay infusion. What are the differences in a protozoan cell which cause difference in response to apparently identical external conditions at different times?

2. Survival time (resistance) of Paramecia and Didinia in solutions of $\mathrm{KCN}$ was selected and used as an index because of the generally supposed relation of the toxic action of $\mathrm{KCN}$ to the rate of oxidation in cells.

3. All the data on survival time of Paramecium and Didinium were obtained by observations on individual cells and not by estimating the average survival time of large numbers of cells as is usual in such experiments. In this way the variation in resistance of the cell at different times during the period between cell divisions was followed accurately and is summarized in curves. 
4. The cessation of movement of Paramecium is a less variable "end point" than cytolysis for determining the death point in $\mathrm{KCN}$ solutions.

5. Paramecia can be cultivated in pure line mass cultures in tap water when fed compressed yeast. In this way the chemical composition of the medium and food can be kept more constant than has been possible previously in work on Paramecium.

6. Resistance of Paramecium to $\mathrm{KCN}$ when allowed to feed on bacteria shows a marked increase, and when fed on yeast the resistance increases to a smaller degree from the time of division up to the following division. The resistance of Didinia to KCN when fed with Paramecia increased from the time of completion of division until a maximum was reached some time previous to the second division, and then gradually fell before the second division. This rhythm is directly comparable to that found by Lyon and others on echinoderm eggs.

7. When Paramecium and Didinium are prevented from obtaining food the resistance to KCN gradually decreases below its value at the completion of division.

8. Starvation of sister cells of Didinia results in a decrease in difference of survival time in $\mathrm{KCN}$. This original difference in sisters is apparently due to the fact that the food content is not always distributed equally to the daughter cells at division. In Paramecia the distribution of food is practically equal, and here the average difference in survival time between sisters is the same immediately after division as it is after a period of twenty-four hours. This small observed difference is however within the limits of experimental error.

9. The difference in resistance of fed and starved Paramecia and Didinia and the rhythmic change in resistance in the case of Didinia between cell divisions which is closely similar to that found in echinoderm eggs can at present be best explained by assuming that it is due to change in permeability of the cell. Penetration of KCN into the cell and hence its toxic action as measured by survival time, is dependent upon the degree of permeability of the cell at different times. On this assumption rhythm in susceptibility depends primarily upon rhythm in permeability. The possible relation between rate of intracellular 
oxidation or nutrition and cell permeability is at present in the absence of sufficient data an open question.

April 15, I9I8.

Child, C. M.

BIBLIOGRAPHY.

'I5 Senescence and Rejuvenescence. University of Chicago Press, I9I5.

Lillie, Ralph S.

'I6 Rhythmical Changes in the Resistance of the Dividing Sea Urchin Egg to Hypertonic Sea Water and Their Physiological Significance. Jour. Exp. Zoöl., Vol. XXI., pp. 369-402.

Loeb, Jacques, and Wasteneys, H.

'I3 Is Narcosis due to Asphyxiation. Jour. Biol. Chem., Vol. XIV., pp. 5I7523.

Lund, E. J.

'I8 Quantitative Studies on Intracellular Respiration II. Am. Jour. Physiol., Vol. XLV., pp. 365-373.

Lyon, E. P.

'02 Effects of KNC and of Lack of Oxygen upon Fertilized Eggs and Embryos of the Sea Urchin. Am. Jour. Physiol., Vol. VII., pp. 56-75.

Lyon, E. P.

'o4 Rhythms of Susceptibility and of Carbon Dioxide Production in Cleavage. Am. Jour. Physiol., Vol. XI., pp. 52-58.

Mathews, A. P.

'o6 A Note on the Susceptibility of Segmenting Arbacia and Asterias Eggs to Cyanides. Biol. Bull., Vol. XI., pp. I37-I40.

Moore, A. R.

'I5 On the Rhythmical Susceptibility of Developing Sea Urchin Eggs to Hypertonic Sea Water. Biol. Bull., Vol. XXVIII., pp. 253-259.

Spaulding, E. G.

'04 The Rhythm of Immunity and Susceptibility of Fertilized Sea Urchin Eggs to Ether, $\mathrm{HCl}$, and to some Salts. Biol. Bull., Vol. VI., pp. 224-240.

Warburg, 0 .

'I4 Beitrage zur Physiologie der Zelle, insbesonderreuber die OxydationsGeschwindigkeit in Zellen. Ergebn. d. Physiol., Vol. XIV., pp. 253-337. 


\title{
BILATERAL TENDENCIES AND HABITS IN THE TWENTY-RAYED STARFISH PYCNOPODIA HELIENTHOIDES (STIMPSON).
}

\author{
H. P. KJERSKOG-AGERSBORG,
}

Department of Biology, the College of the City of New York, Department of Anatomy, Long Island College Hospital, BROOKLYN, N. Y.

A. Introduction . . . . . . . . . . 232

B. Ecology:

I. Distribution............................... 233

II. Movements:

I. Righting Reactions....................... 234

2. Tidal Movements........................... 240

3. Migratory Movements........................ 244

(a) Reaction toward Light ................... 244

(b) Search for Food .......................... 246

(c) Breeding Impulse ..................... 246

III. Feeding

I. Kinds of Food . . . . . . . . . . . . . . . . 247

2. Methods of Feeding . . . . . . . . . . . . . . . . 247

IV. Conclusions on Movements in General . . . . . . . . . . . . . . 249

V. Meristic Variation . . . . . . . . . . . . . . . . . . . . . 249

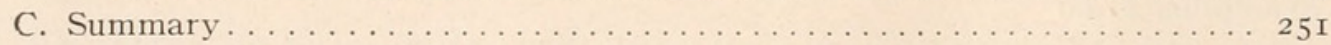

D. Bibliography . . . . . . . . . . . 252

\section{INTRODUCTION.}

The purpose of the investigation upon which this paper is based is to show to what extent the radial symmetry in Pycnopodia helienthoides is disturbed by its bilateral tendencies.

The nature of the investigation has been primarily based on observations on the animal in its native home, and as little as possible have conditions been introduced during experimentations which would deviate from that of its natural abode.

The carrying out of this experimental work on Pycnopodia was done in connection with other work at the University of Washington, during the year I9I 5 , and during part of the summer of I9I6. The experimental work was done at Bremerton, Wash., which is situated about twelve miles from Seattle. In some of 
the bays at Bremerton, Pycnopodia had congregated in superabundance, offering a considerable inducement to perform experiments on them there, rather than anywhere else on the Puget Sound. And although much time was consumed in traveling between Seattle and Bremerton, the abundance of specimens at the latter place compensated fully for the time thus lost. Occasionally a number of specimens were brought from Bremerton and planted in Elliot Bay at West Seattle for the purpose of studying them there, but when the salinity was found to fluctuate more at the latter place than at the former, it was thought unwise to study them in the new place as under normal conditions and the efore, Bremerton was selected as the most logical place for collecting these data.

ECOLOGY.

\section{Distribution.}

Pycnopodia helienthoides is found along the Pacific Coast from central California to southeastern Alaska. It inhabits the entire Laminarian Zone, $i$. e., from low-water down to a depth of fifty fathoms, or even beyond that. Very seldom is it caught above low-water mark. When thus found, it is generally in pools where the water remains fresh till the tide returns; when found on piles under docks, after the tide has run out, it is because of the fact that Pycnopodia does not readily move backward or sidewise, but uses the side established as fore-end, always as anterior end. In places where the bottom is sandy and void of food and where nearby piles are covered with barnacles, Pycnopodia may be found, at low-tide, above the water-line. As was clearly demonstrated by some of the samples that were brought to West Seattle and placed under an old dock there, at low-tide a goodly number of them were found hanging on the dry piles. These piles were covered with barnacles and the bottom below was very sandy and depleted of all kinds of food. The writer has never found a duplication of this in other places, however. It may be that the star in this particu'ar instance was exceptionally hungry and did not notice the decreased pressure as the tide receded; in places where food is readily obtained elsewhere, Pycnopodia, as a rule, keeps below water.

The Puget Sound region is well suited to Pycnopodia. The 
temperature, moderate during the entire year, the many sheltered bays and the great abundance of food are undoubtedly contributing factors for the presence of this species of starfish in large numbers. Professor Kincaid, while dredging for marine specimens in connection with work at the Puget Sound Marine Station at Friday Harbor, has come to places where he has got the dredge absolutely full of Pycnopodia.

The coast-lines along the shores of the bays at Bremerton, especially along the shores of the town, are literally covered with starfish of various species. The most numerous is the Evasterias troschelii (Simpson); then, the species Piaster ochraceus (Brandt); $P$. paucispinus and Dermasterias imbricata are also found as well as Pycnopodia. The numeric ratio of the four former is one $P$. ocraceus to twenty-five $E$. troschelii; one $P$. paucispinus to fifty E. Troschelii, and as many Dermasterias as $P$. ochraceus. There is a considerable variation in the number of rays of $E$. troschelii. The normal number is of course five, but many have six rays, others seven, and still others four. These species occur in certain belts along the shore, $e . g$., Evasterias occurs the farthest up; in the lower part of this belt, and extending below, is $P$. paucispinus. $P$. ochraceus is seldom found above low-water mark, and together with it are Dermasterias and Pycnopodia. This may then be taken as the upper limit for Pycnopodia, and the lower limit as that as stated before, about fifty fathoms. It is in this respect common with members of the related family Brisingidæ (Sars, I875), e. g., Labidiaster radiosus (Lütken) which, according to Ludwig, occurs in the south Atlantic and south Pacific oceans, in the littoral zone. Verrill, referring to the same species, says: "Unlike the other forms of Brisingidæ, it lives in shallow water as well as at considerable depths. It is found on both coasts of Patagonia and off Cape Horn, etc."

\section{Movements.}

Righting Reactions.

When experimenting on righting reactions care was taken so that the specimens would be under as normal conditions as possible, and no restrictions were put on them. A large number of trials were made in nature without taking any data; but the 
striking similarity of reactions when disturbed gave cause for recording carefully the actual means and manners of righting. A small specimen from shallow water demonstrated very strikingly when put in a large tub of sea-water that Pycnopodia has a marked control of its radial muscles. That is to say, it has greater power of correlation of muscles than perhaps any other starfish. Out of fifty trials on the same specimen, forty-six turns were toward the same side, three turns toward the opposite side, and one turn at right angles. After one becomes familiar with the general method of righting reactions which Pycnopodia follows, one can easily notice any other method it may adopt or chance upon in an effort to right itself. It makes no difference as to the direction of the rays of light, the star uses the anterior end, as initiative end, in turning. To illustrate: When this species is turned on its back it immediately commences to put its anterior end under its back (Figs. I, 2, Plate I.), attaching the sucker-feet to the bottom and pulling with them, while with he opposite end, also curved under, it pushes until the dorsal side is up. To right itself in the direction most usually followed, au unified impulse is apparent as soon as the star has been turned on its back. One may keep experimenting in this way almost indefinitely with the same result as above. The turning over toward the right angle happened perhaps accidentally, in that one ray which was at right angles to the anterior ray caught hold on the bottom first, and the pull begun in that direction, the other rays coöperating, pushing or pulling. Such a turn, however, as seen in the appended table, takes by far much longer time than even the slowest righting reaction toward the posterior or anterior ends. Therefore, when abnormal rightings occur, they are apparently due to fatigue or confusion, as the movements at the beginning of experiments are always in the same direction, provided that the specimens be taken from fresh and tolerably shallow water. Experiments on specimens which had been kept in a vessel for some time, invariably gave fluctuating results; they would act as if unbalanced, a fact undoubtedly due to the deoxygenation of the water. Other factors, external and internal enter in also. Externally there is the change in temperature as well as the depletion of oxygen; internally there is the effect of 
external conditions. The lack of oxygen, or the insufficient amount of it causes, as demonstrated by Loeb (6) and others, ". . . at first molecular, and later morphological changes in the cells, which in turn are the cause of the supension of life-phenomenon." No apparent morphological changes were observed on the star from the lack of oxygen, but the unbalanced behavior seems to indicate some changes to have taken place. The effect of the stimuli received from the righting impulse, whether it be a normal or an abnormal individual, is to move away from the place of disturbance. (Fig. 3, Plate I).

Such definite movements tend to show that Pycnopodia has some established habits. In this respect it is indeed very much different from the common starfish, e. g., Asterias forbesi and $A$. vulgaris, which, according to Dr. Coe (2), "Do the same thing, under the same conditions, in a number of different ways, and never do the same thing twice in exactly the same way."

Jennings (4) also makes a statement similar to that of Dr. Coe, when he says: "The starfish Asterias firreri) is not hampered by any consideration of anterior or posterior; it may move with any of its rays in the lead, or with any interradius in advance, or indeed in any intermediate direction, so that its possibilities as to direction of locomotion are really unlimited. In the same way, it may right itself in an indefinite number of different ways." Pycnopodia, however, has already formed certain definite modes of behavior. Part of these is indicated by its righting reactions. The speed of righting, as seen below, is not improved by repetition, but the method of righting indicates clearly that it possesses a more definite control of its muscles, or has a more definite method of righting itself than has the common starfish. In regard to habit formation the result is negative.

Jennings (4), in describing the righting reactions of the common starfish, says: "After repeated experiences by a given individual, there was no improvement in the performance of this reaction, either in the time taken, or in the movements employed in accomplishing the righting."

The first eleven trials show uniformity in speed of righting reaction; the first three show the same speed. Then there is a very rapid turn, taking only half the time of one of the previous 
Rate of Righting Reactions: Experiments carried out on April 4th, i9i5. Number of Trials. Time. Temperature $10^{\circ} \mathrm{C}$.

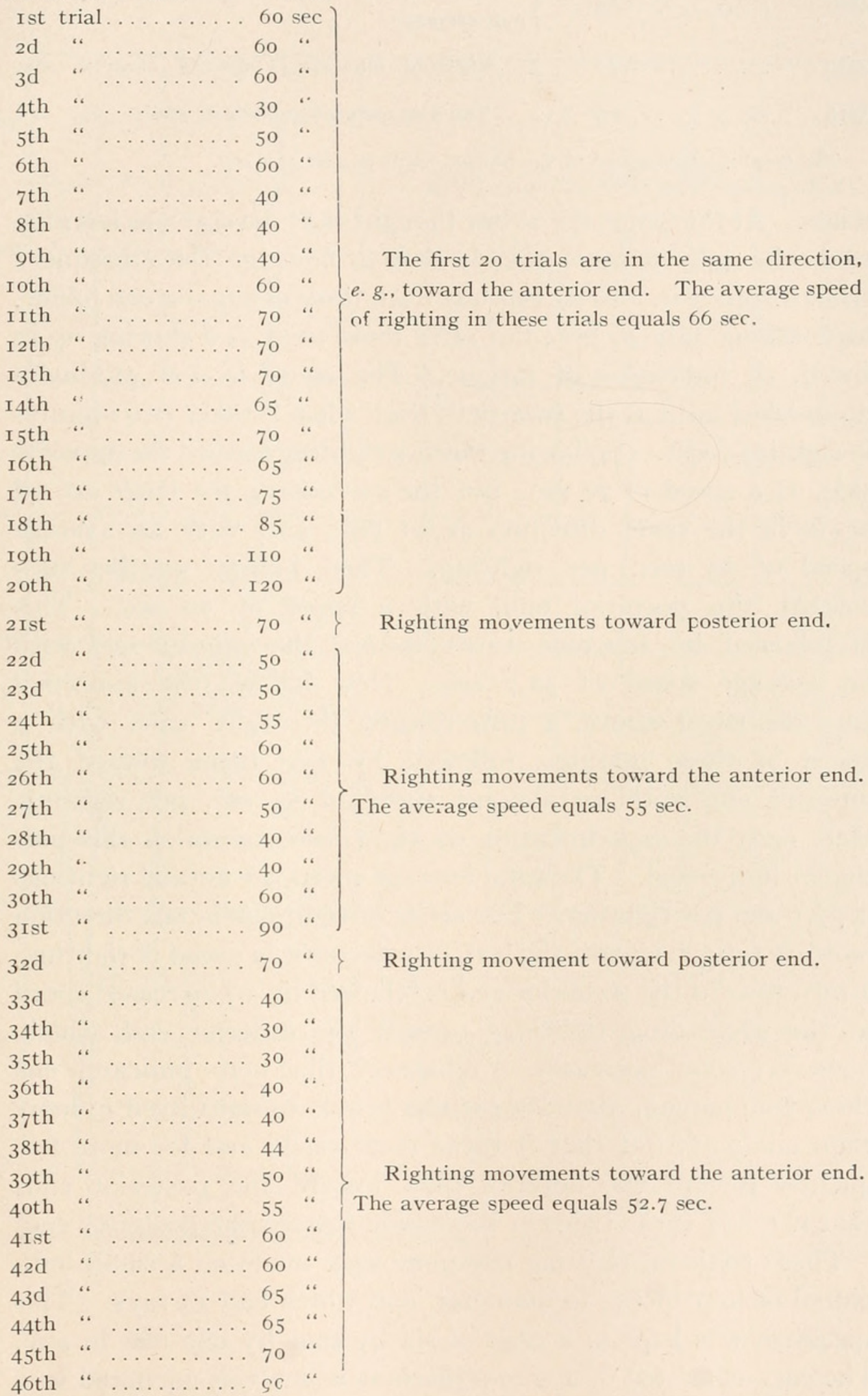




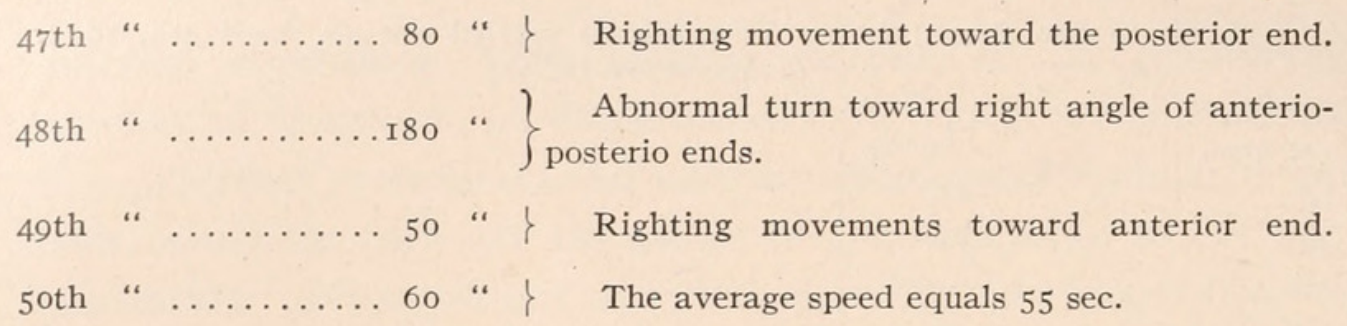

The total average speed of the normal turns equals 57.I sec.

trials. At this point the writer thought that the star was learning to do the righting more quickly than at first, but the subsequent trials disprove it. After this last trial, three of equal speed follow, each taking only $40 \mathrm{sec}$, but after these there is a slowing up in speed, an indication of fatigue. The speed is now gradually diminished until at the twentieth trial, when it takes two minutes in righting itself. Following this is a righting toward the opposite side, at a speed of $70 \mathrm{sec}$, but the succeeding ten trials are all again in the same direction as at first, and with an average speed of 55 sec., per righting. Then follows another turn toward the posterior end, with a speed of $70 \mathrm{sec}$. This is followed by fourteen turns toward the anterior end with an average speed of $52.7 \mathrm{sec}$. Now follows the abnormal turn described above, a turn toward the right side, with a speed of three minutes, followed by two turns toward the anterior end with an average speed of $55 \mathrm{sec}$. per righting. Here ends the experimenting on right movements on this particular individual. The total average speed per normal rightings is 57.I sec. per righting. The series of rightings in one direction indicate fatigue toward the last, or a decrease in speed of righting; a turn toward the posterior end is followed by an increased speed in the succeeding rightings toward the anterior end, which, however, soon decreases. Whatever this may indicate, one thing is apparent: that Pycnopodia is able to right itself in more than one way, but that it turns more easily and far more frequently toward the anterior than toward the posterior end; that it never turns twice in succession toward the posterior end.

These trials on righting reactions were made on a small individual of four inches in diameter, and which had 13 rays. This specimen was kept in a cage of six by four by one feet in size. The cage consisted of a wire-aquarium which was anchored to a 
BILATERAL TENDENCIES IN PYCNOPODIA HELIENTHOIDES. 239

FIG。 I.

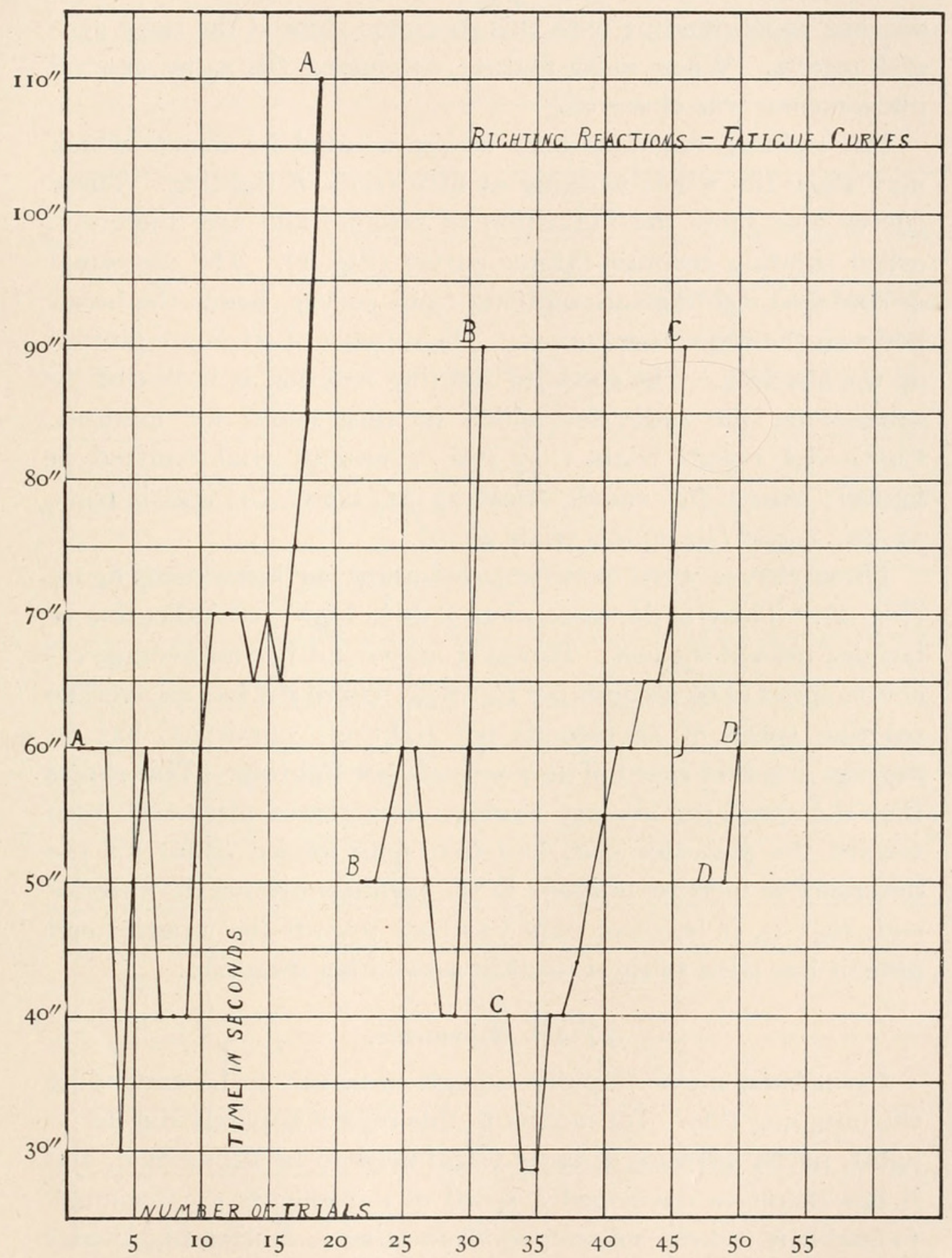


float. The specimen was fed on small shell-fish of the families Cardiidæ and Leptonidæ; on gasteropods: Amphissa versicolor and also on crabs (Pugettia gracilis, Cancer orgonensis). Subsequent experimenting with this specimen showed the same general results. When using mature specimens the same general phenomenon was observed.

The righting reactions may be represented by curves which may show the whole working of fifty trials of righting. These curves also show the indication of fatigue, and are, therefore, called righting reaction-fatigue curves (Fig. I). The abnormal or confused rightings are omitted from curves, hence the break between the respective curves. The number of trials are plotted on the abscissa. The speed in righting reaction is indicated by squares on the ordinates which in turn stand for minutes. Curve $A A$ equals trials $\mathrm{I}-\mathrm{I} 9$ (the twentieth trial omitted in figure); curve $B B$ equals trials 22-3I; curve $C C$ equals trials 33-46; curve $D D$ equals trials 49-50.

These curves when superimposed show an interesting figure (Fig. 2). There is the same picture as in Fig. I, an indication of fatigue, toward the last. However, curve $A A$ has an average reaction speed of 66 seconds per righting; curve $B B$ has an average reaction speed of 55 seconds per righting; curve $C C$ has an average reaction speed of 52.7 seconds per righting. This shows that the speed per average reaction is increased after each turn toward the posterior end, and that may indeed count for the difference in increase of speed in the turnings toward the anterior end, that is, it becomes easier to turn toward the anterior end after it has tried to right itself in some other direction.

\section{Tidal Movements.}

Pycnopodia moves rapidly enough so as not to be caught by the outgoing tide. Its success in this regard is partly due to its habit, partly because of its physical need to be submerged, and it has therefore developed a speed of movements great enough to enable it to keep submerged all the time. During high-water it may move a considerable distance above low-water mark, and during such time be found on grounds which will be dry at low-water. In such cases it will move a little ahead of the tide, 
BILATERAL TENDENCIES IN PYCNOPODIA HELIENTHOIDES. 24I

FIG. 2 .

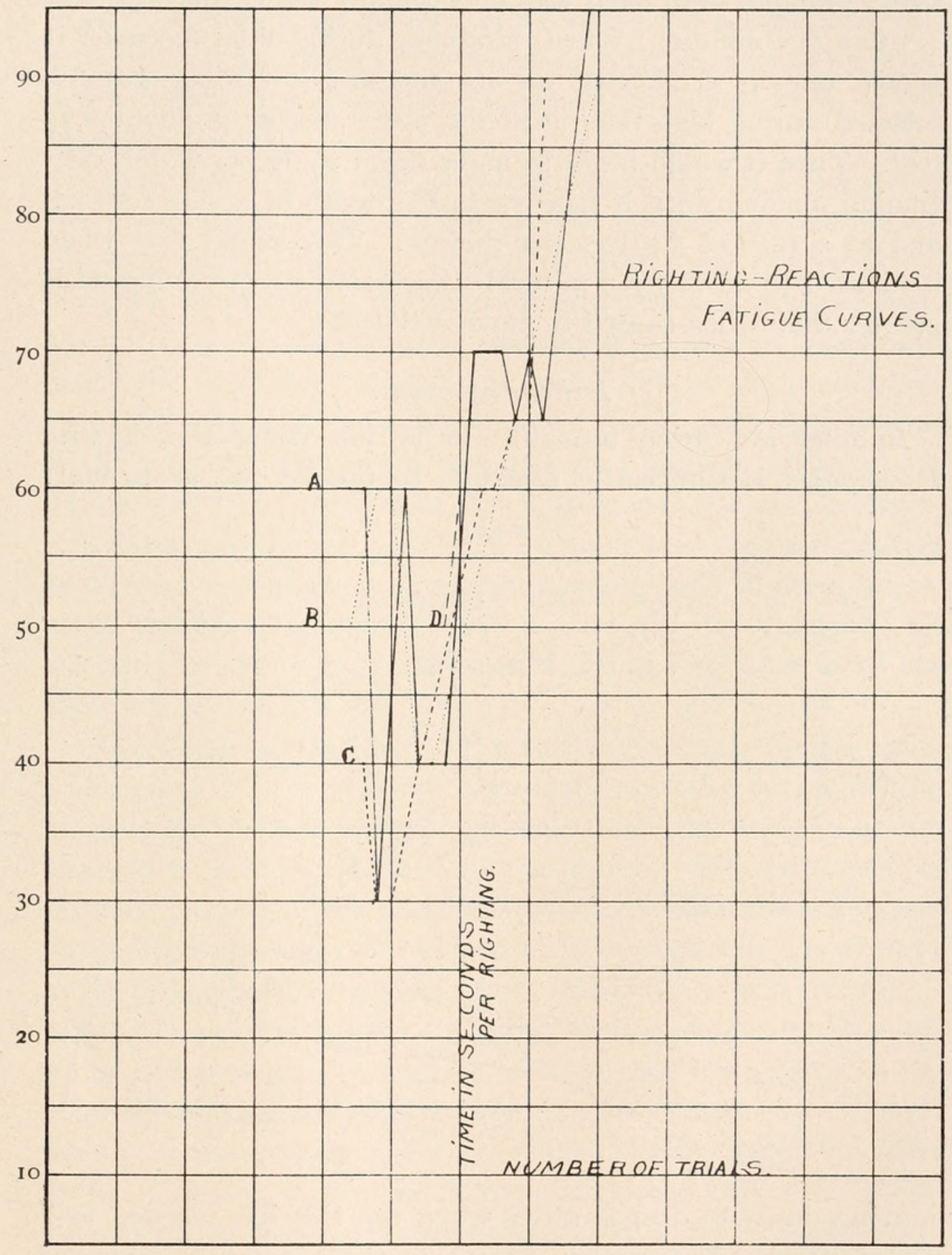


as the tide runs out. The rate of speed of such distance-movements depends on the circumstances. For example, when instigated to move by some artificial means, as by being turned on its back, brought from deep water to shallow water, the rate was 2.5 feet per minute. When, however, during tidal recession it would remain stationary on its temporary feeding ground, selected during high-tide, until the water measured about 2.75 feet. Then it would begin to move down to deeper water, continuing moving until it had reached a depth of about 4.5 feet, and at a rate of 3.5 feet per minute. This shows that when instigated to move by a natural stimulation its rate of speed is greater than when caused to move artificially.

\section{Irritability Limit.}

Another indication brought out in this connection is that Pycnopodia is sufficiently sensitive to pressure so as to start

FIG. 3 .
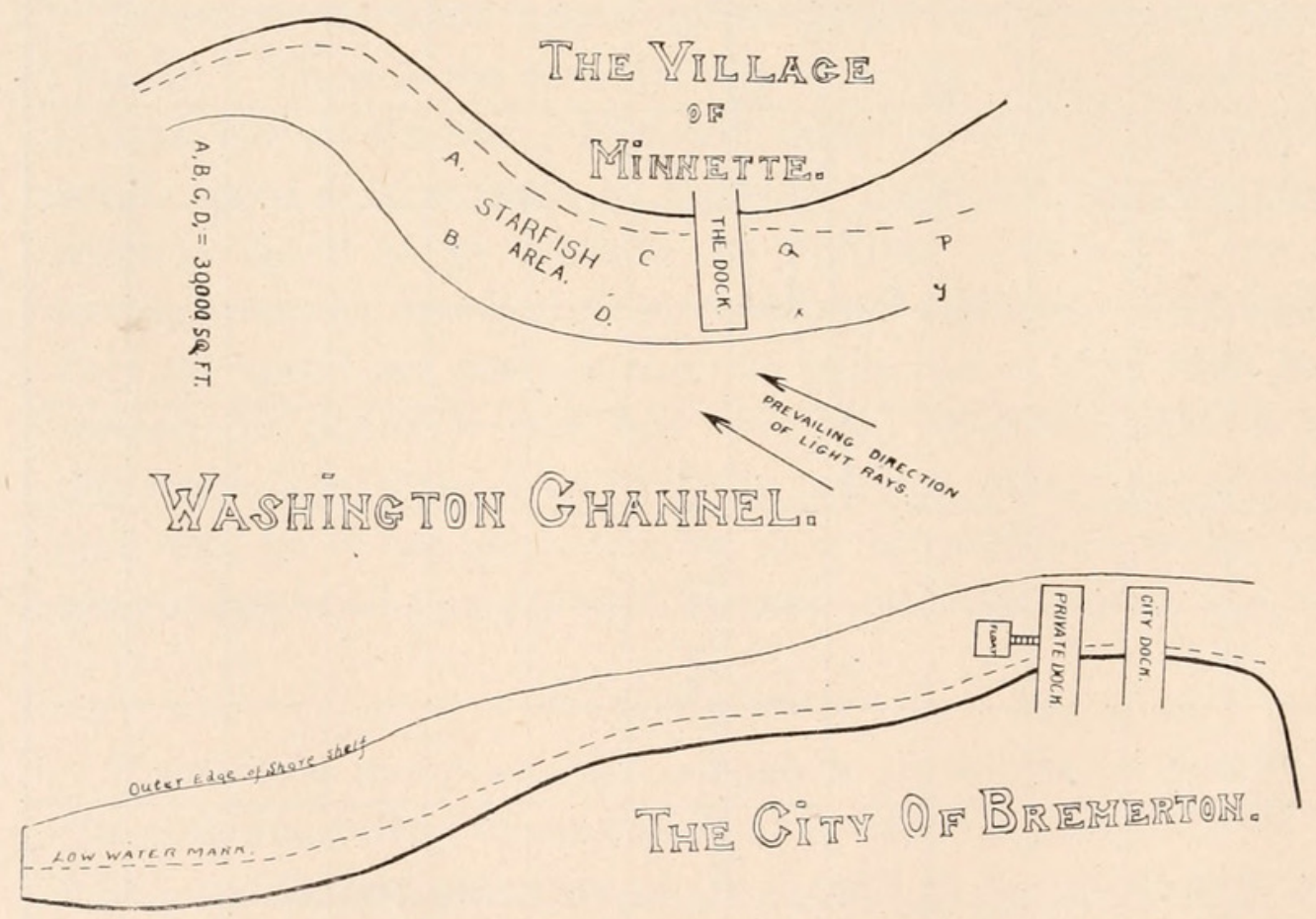

moving down to deeper water when the tide has receded to a certain level. As a matter of fact, out of seventy-five specimens that were examined during one low-tide on a given area (Fig. 3 ), only two were at the shallow depth of 2.5 feet. Specimens brought from deeper water to shallower water, that is from any 
depth (see topic on distribution, p. 233) to a depth of about three feet, will move down to a depth of at least five feet. Then the irritability limit ranges between the pressure of 2.5 feet and 5 feet of sea water. The average depth of the 75 specimens referred to above, on an area of about 30,000 square feet, was 4.76 feet. The minimum pressure in this irritability limit, to which Pycnopodia is adapted, is seen to be about I.I3 lb. to the square inch.

An irritability limit may seem improbable when it is considered that this starfish has been found on piles above water and on dry tide-flats during low-tide. Either of these cases is very extraordinary, in that tidal recession on tide-flats is sometimes great enough even to catch swiftly swimming fishes. On piles onto which the gluttonous starfish has been lured by the presence of barnacles, the tidal recession is indeed the slowest possible, but in this case the star is in a very awkward position to move. It has already been stated that the righting movements are almost invariably toward the same side. This is also the case relative to distance-movements. One end is, much more so, than in any other starfish, the anterior end; Pycnopodia has a decided bilaterality in this regard. That is, it is used to move with the same side as anterior end.

When it moves the rays are curved at the ends, the eye-spots wide open. The second pair of primary posterior rays is pulling along with the odd posterior primary ray; the sucker-feet are engaged in a lively and continuous march. The third pair of primary posterior rays is occasionally lifted foreward spontaneously, while the first pair of the post-larvel rays which is at right angle to the anterio-posterior rays, when the star is at rest, is lagging somewhat behind. During such movements, this anterior end is decidedly used as such, so that when the star encounters obstacles which it may not crawl under or over, it merely, as an ordinary bilateral animal, turns toward its right or left side. It does not, in such instances, utilize its radial symmetry by starting to move backward or to the right angle or to any other angle to its longitudinal axis. 


\section{Migratory Movements.}

Statements have already been made to the point that Pycnopodia possesses locomotive powers great enough so as not to be caught by the outgoing tide, provided that the land is not too flat. The rate of tidal recession, even during times of extreme low-tide, will not be faster on a slope of six inches to the distance of twelve and a half feet, than Pycnopodia is able to keep pace with. In addition to these kinds of movements which have been mentioned, Pycnopodia seems to move according to seasons of the year. Seasonal movements, as they may be called, have three underlying primary causes, to wit: reaction toward light, search for food, and the breeding impulse. These three are causes for extensive migrations.

Reaction toward Light.-During the summer time Pycnopodia is found, as a rule, in deeper waters. If found in shallow water during this time of the year it will almost always be in shaded places, as under docks, under kelp, algæ or on the shaded side of a bay. This seems to point to negative heliotropism. In the spring, I9I 5, during the breeding season, Pycnopodia was found actually congregated in large numbers on the sunny side of the bay, but two months later there was not a single specimen on that side of the bay, while on the shaded side of the same bay a few were found under a dock, but farther out than during the spring and winter. Movements of this nature vary, however. As was seen during the summer of I9I6, when the whole summer was exceptionally rainy, cloudy and cool, Pycnopodia seemed to take advantage of such conditions and remained in shallow water all the time. August, however, proved to be more sunny and warm than the early part of the summer, with the effect that the rays of the sun became annoying to the star. This unexpected and intense light caused every single specimen, as far as could be observed, to move away, either down to deeper water or to hide under some object. The dock, as an illustration (Fig. 3, Minette side of the bay, starfish area $A C B D$ ), served as a satisfactory shading place, where Pycnopodia actually congregated in a continuous layer from three feet depth to as far as could be seen at low-water. The question arises: How did the star find the dock to hide under when the sunny days of August suddenly came? 
The dock, as seen in Fig. 3, is located near the point of the Minette side of Washington Channel, opposite the City of Bremerton. On no occasion has the writer observed Pycnopodia on the outside of the dock or in the area $Q P X Y$, but always on the inner side, toward the Washington Channel. The sudden continuous sunshine which came in August with the temperature the highest in the year soon made itself felt to the negative heliotropic star. Observation on the direction of the rays of light during the middle of the day explains this phenomenon. The light rays of the late forenoon and early afternoon are up the channel, or diagonally from the dock toward the starfish field, $A C B D$. The cause for the movements and orientation of the star in this particular case must be sought in the phenomenon of the effect of the direction of the most intense rays of light.

Loeb (6), working on Spirographis spallanzanii, found that rays of light, if sufficiently intense, are unequivocally able to determine the orientation. In summarizing the causes for moving to or from the source of light, he says: "The direction of the median plane of an animal coincides with the direction of the rays of light. Light of a constant intensity acts as a constant stimulus, in animals as well as in plants." These statements seem to explain why Pycnopodia "found" the dock. The star, however, moved toward the source of light, and according to Loeb's conception of the behavior of heliotropic animals, that should make Pycnopodia positively heliotropic, for, "Positively heliotropic animals will move toward the source of light, even if in so doing they go from places of greater intensity of light to places of less intensity." When the star, however, came under a good shading object, such as the dock offered, it remained there for several weeks, and did not venture away from the dock in either direction.

As was said above, Pycnopodia occurs in shallow water during the spring and late winter, and in deep water during the lightest part of the year. The early part of summer and late part of winter are the regular migratory periods. The causes for migratory impulses have been designated as three: the effect of the rays of light, search for food and the breeding impulse. But in a rather large number of cases movements of Pycnopodia at the 
two stated periods may not be effected by any one of these causes, separately. For still other factors enter it, and, therefore, more frequently several causes may coöperate, resulting in definite movements at the same time. Thus the variable conditions within the animal may cause different reactions toward light at various times.

Loeb (6) has shown that the caterpillars of Porthesia chrysorrhcea, after fasting through the winter, are energetically positively heliotropic; but that after these animals have eaten, heliotropism is not shown so definitely Plant lice become positively heliotropic only after they have fed; the larvæ Musea vomitoria are energetically negatively heliotropic only when fully grown, etc.

Heliotropism in Pycnopodia is, however, only a partial cause for migration or distance-movements, and the periods of migration are not very definitely marked; they are quite extended in time. Various external conditions, as well as internal, contribute to this.

Search for Food.-The food problem is another factor which determines the distance-movements in Pycnopodia. It will, like other starfish, move according to the distribution of food. If Pycnopodia finds its surroundings scarce in food material, it has no difficulty in taking leave for different grounds. In fact, as it has been found in bays at a depth of twenty fathoms where there would be a great variety of food, e. g., sea-urchins (Strongylocentrotus dröbaciencis), Pectens, Yoldia, etc., when conditions for it would not be favorable to remain on other grounds, such as in shallow water during the summer, indications seem to point that way.

Breeding Impulse.-Temperature together with the impulse to breed are still other causes for migration. The temperature below ten fathoms is comparatively constant during the entire year, while the temperature at the surface varies quite considerable during the year. The lowest and highest temperatures during the year I9I5 were $9^{\circ} \mathrm{C}$. and $16^{\circ} \mathrm{C}$. respectively. That Pycnopodia should move up to shallow water during the spawning season seems reasonable, for the temperature in deeper waters is undoubtedly lower than at the surface even during the spring. Reference was made 
above to the fact that Pycnopodia was found in large numbers on a certain side of a bay, during spring, while it was totally absent from these grounds later on, during the summer. As a matter of fact, during the spring of I9I5, on the area $A C B D$ (Fig. 3) more than one hundred specimens were counted, while in July of the same year not a single specimen was seen on the same area. The change in habitat was perhaps due to the intense sunlight, as during the cool and rainy summer of 1916 , a large number was seen on the same area until constant sunny weather ensued. As demonstrated above, this is an indication of positive heliotropism. The habitat of Pycnopodia ranges over the entire belt of the laminarian Benthos; it lives as a rule in deeper water during the warm and light part of the year, and in shallower water during the spawning season and during the darker and colder part of the year.

\section{FEEDING.}

Kinds of Food.

The feeding habit of Pycnopodia is striking and very interesting indeed. It lives on such types of mollusks as clams and gasterpods; on crustaceans, such as crabs and barnacles; on other echinoderms, such as common starfish and sea-urchins; on porifera, and on algæ.

\section{Methods of Feeding.}

The methods of feeding are by engulfing and sucking. Large rocks up to a pound in weight have been found in the stomach. These were engulfed when sucking on barnacles, because markings of barnacles could be seen on the rocks. The large horse clam (Schizotharus nauttalli) cannot be engulfed on account of its enormous size. But when Pycnopodia encounters Schizotha$r u s$, it rolls itself around the latter and proceeds to digest it. On one occasion the writer found the star in the act of consuming one of these large horse clams. The extraordinary large syphon was forced into the mouth of the starfish while the everted stomach was folded around the syphon. The whole star had in fact, rolled itself around the clam, endeavoring to pull it open. This pulling on the part of the star had, however, no effect on the clam, for, although the latter might have relaxed to the continuous pull of the sucker-feet, it was of no avail because the folds 
of the stomach of the star could not reach the vital parts of the clam exposed by the relaxation of the adductor muscles. The reason for the failure to kill the clam was due to the fact that the syphon of the clam, as stated before, was extended into the mouth of the star. The star seemed to have no effect on the clam, except that the syphon was partly digested around the edges of its apertures. Otherwise the clam seemed to have enjoyed the gastric juices of the star; it was still alive and behaved like unmolested clams of the same kind, when it was freed from its pursuer. Small clams are more easily preyed upon. Ordinary cockles are as a rule engulfed. In opening cockles or smaller clams, Pycnopodia holds its prey until it has a chance to force some of its everted stomach into the shell-fish, and having succeeded partly in this respect, it digests its prey piecemeal. In other instances, members of the family Natidæ (e.g., Nassa mendica) were found in the stomach of this starfish, together with egg-bodies of Natidæ. As a matter of fact, Pycnopodia feeds especially on gasteropods, engulfing the smaller ones, as in the case of the last referred to. Polynices, though a monster of a slug, is a very easy prey, indeed, to Pycnopodia. In fact few, of this slug are found on grounds common to Pycnopodia. From experiment it was found that Polynices is very sensitive to the surface of this star. When keeping several Polynices in the aquarium with one Pycnopodia, it was found that the latter devoured three large (foot, about 8 inches long, 5 inches wide, and 4 inches deep) specimens in three days, leaving the shells on the outside. The method of feeding on these slugs is simply by suffocation. The slug seems to be incapable of living very long within its shell, and unless it is allowed to take in fresh water, when relaxing, it soon has to come out as a mere powerless, defenseless matter of flesh. When, therefore, Pycnopodia has Polynices in its control, the latter must very shortly give in to the former. In still other instances, remnants of crabs were found in the stomach of this star also. In this connection, experiments on feeding it with crabs were actually performed. Having stabbed a crab (Magister productus), it was thrown into the water so that it would fall down beside or on the top of the star. In one such instance, the latter seized the crab-fragments 
with its pedicellariæ and crawled away with it to deeper water, and then started to feed on it there. In another instance, the star started to feed on the dead crab at once. In so doing it put the rays over the crab, tucking it under itself, rising on the tips of its rays and in this way proceeded to devour its meal. In yet another instance it was found that Pycnopodia was feeding on other starfish (Evasterias troscehlii), and this even though there seemed to be plenty of gasteropods and other mollusks present. It was also found to be feeding on Strongylocentrotus dröbachiensis. Finally Pycnopodia feeds on porifera and on plants - of the latter, kelps and algæ. This last kind of food is probably resorted to when clams and gasteropods are beyond its reach. Because of these various types of food that this starfish feeds on, it may well be said that Pycnopodia is omnivorous in its habits of feeding.

\section{Conclusion on Movements in General.}

The fact that Pycnopodia always moves along one and the same axis, with the same side always as anterior end; the fact that it has a definite method of righting itself, as well as apparent voluntary behavior during feeding, seems to point to dominating bilateral symmetry rather than radial symmetry. With such evidence of dominating bilateral symmetry, one should expect a nervous system more complex than that of the ordinary starfish. Indeed, something relative to experiments on the regenerative powers of this genus seems to point that way. The regenerative powers in Pycnopodia seems to be less than in the common starfish.

\section{Meristic Variation.}

The Modal Curve.

The modal point of rays in males, females and immature specimens is represented in Fig. 4. That of the female, IIBB' shows an abrupt demarcation, in that the average modal point of number of rays is reached before maturity, while that of the male fluctuates. This fluctuation, however, is the same after the modal point is reached, but is of course greatest, regardless of sex, among the immature, although that particular number which was examined showed a modal point much the same as that of the mature ones (Fig. 4, IAA', males; IIICC', 
immatures). This was no doubt due to the fact that only a few small ones were found, and those found were approaching maturity. Curves representing the diameter may also be plotted (Fig. $4, A^{\prime} B^{\prime} C^{\prime}$ ). In each case the diameter which is measured

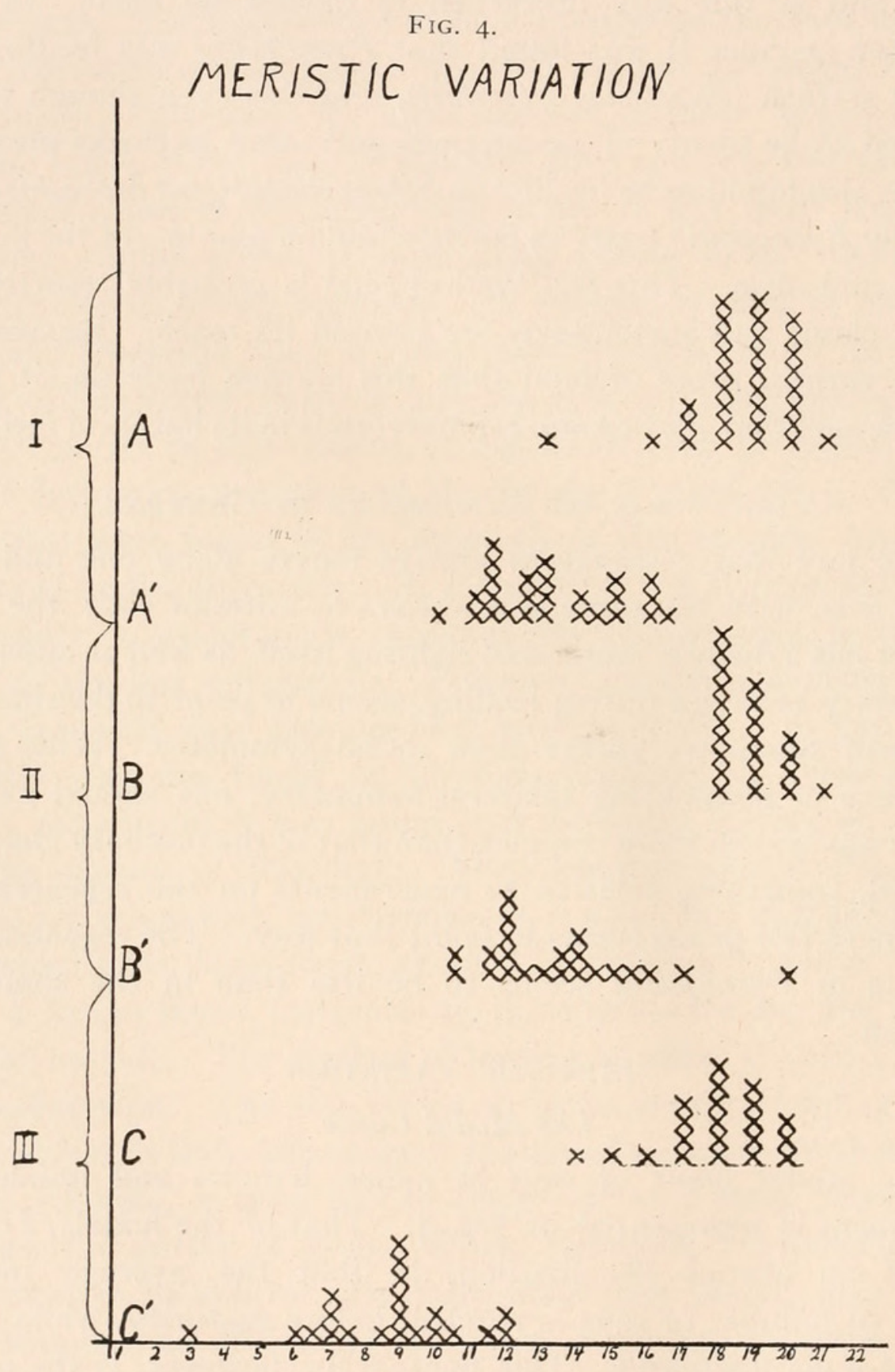

in inches from tip to tip of rays along the median axis is plotted on the abscissas, the number of specimens on the ordinates.

Ritter and Crocker (9) states that out of one hundred specimens that they studied not one was of the I8-rayed stage. Here, how- 
ever, the modal point in both the male and female is seen to be $\mathbf{I} 8$. The adult cannot be determined by the number of rays, because the immature star may reach the modal point in number of rays, and like mature specimens go beyond the modal point, and even not reach maturity, while on the other hand mature male specimens may be found to have only $\mathrm{I} 3$ rays, which is reaching down into the immaturity limit. Mature specimens spoken of here have special reference to sexual maturity for that season. The modal point of both males and females is practically the same.

This is demonstrated by a number of specimens examined in the same region on the same day, and represented by Fig. 4, $I, A$ (male), $I I, B$ (female). As a matter of fact, the average number of rays in the male, female and immature is almost the same, which goes to show that radial development occurs in the comparatively early part of the life of the individual star. On this occasion, the depth for and the diameter of every specimen was measured; and the number of rays present, and the sex was determined. These findings were as follows:

I. The average depth at low-tide for 75 specimens found in a belt 30 feet wide by $\frac{1}{5}$ of a mile long was 4.76 feet.

2. The diameter measured along the median axis from tip to tip of odd anterior and odd posterior rays for immature was 8.2 I inches, and the average number of rays was I 7.85 .

3. The average diameter of the males was 13.5 inches, and the average number of rays was 18.56 .

4. The average diameter of the female was I3.6 inches; the average number of rays was I8.8.

\section{SUMMARY.}

I. Pycnopodia is highly bilateral when moving about in its natural abode. It uses the same side always as anterior end.

2. During righting reactions, this same side almost always takes the initiative and the greatest number of rightings are made in that direction. Repeated rightings do not improve its speed.

3. It is hardly ever found on dry land; its movements are swift enough so that it keeps below the tidal mark; it moves swiftest when stimulated from within. 
4. In this, it seems to be partly governed by its sense to the pressure of minimum depths.

5. Three prime causes effect its migratory habits, to wit: (I) sensitivity to light of a certain intensity; (2) search for food; and (3) the breeding impulse. During the breeding season it is neither negative nor positive heliotropic; for it moves up from deeper water to shallower water independently of the directions of the rays of light. After spawning, however, it seems to be positive heliotropic.

6. It is omnivorous; it is carnivorous. It feeds mainly on Gasteropoda, but also on Pelecypoda, other species of starfish, sea-urchins, crabs, sponges, kelps and algæ.

7. The female seems to have reached a more definite number of rays before maturity, than has the male (see Fig. 4).

8. Maturity is not entirely dependent on the size of the animal; i.e., the diameter varies: In immature up to $\mathrm{I} 2$ inches; in males from IO-I $6 \frac{1}{2}$ inches; in females from $10 \frac{1}{2}-20$ inches. The females are on the average larger than are the males.

I. Arnóld, Augusta Foote

\section{BIBLIOGRAPHY.}

'I3 The Sea-Beach at Ebb-Tide. The Century Co., New York.

2. Coe, Dr. W. R.

'I2 Echinoderms of Connecticut, Hartford. Bulletin No. I9, Connecticut Geological and Natural History Survey.

3. 'o6 Behavior of Lower Organisms. The Columbia University Press, New York.

4. Jennings, H. S.

'o7 Behavior of the Starfish Asterias Forreri de Loriol. Univ. Cal. Publications in Zoölogy, Vol. 4, No. 2, pp. 53-185.

5. Loeb, Dr. Jacques

'o3 Comparative Physiology of the Brain and Comparative Psychology. G. P. Putnam's Sons, New York; John Murray, London.

6. 'I5 Studies in General Physiology. The Decennial Publications of the Univ. of Chicago, Second Series, Vol. XV., Part I.

7. Ludwig, Dr. Hubert

'99 Dr. H. G. Bronn's Klassen und Ordnungen des Thier-Reiches, II. Buch, Die Seesterne. C. F. Winter'sche Velagshandlung, Leipzig.

8. MacBride, E. W.

'o9 Echinodermata. The Cambridge Natural History. Vol. I., Macmillan and Co., London.

9. Ritter, Wm. E. and Gulielma R. Crocker

'oo Multiplication of Rays and Bilateral Symmetry in the 20-Rayed Starfish Pycnopodia Helienthoides (Stimpson). Proceedings of the Washington Academy of Sciences, Vol. II., pp. 247-274. 
BILATERAL TENDENCIES IN PYCNOPODIA HELIENTHOIDES. 253

I0. Sars, G. O.

'7I Forhanlinger i Videnselskabet i Kristiania. Side I-6.

II. Verrill, Professor A. E.

'o9 Remarkable Development of Starfishes on the Northwest American Coast; Hybridism; Multiplicity of Rays; Teratology; Problems in Evolution; Geographical Distribution. The American Naturalist, Vol. XLIII.

12. 'I4 Monograph of the Shallow-Water Starfishes of the North Pacific Coast from the Arctic Ocean to California. Harriman Alaska Series, Vol. XIV., Parts I.-II. 


\section{Explanation to Plate I.}

FIGs. I-3. Photos of Pycnopodia helienthoides (Stimpson), showing righting movements; Fig. I shows the ventral side, and the beginning of righting. Note the outstretching tube-feet; Fig. 2 shows the same specimen ten seconds later, almost semi-righted: Fig. 3 shows the righted specimen, just after righting active y moving along $\frac{1}{7}$ natural size. 


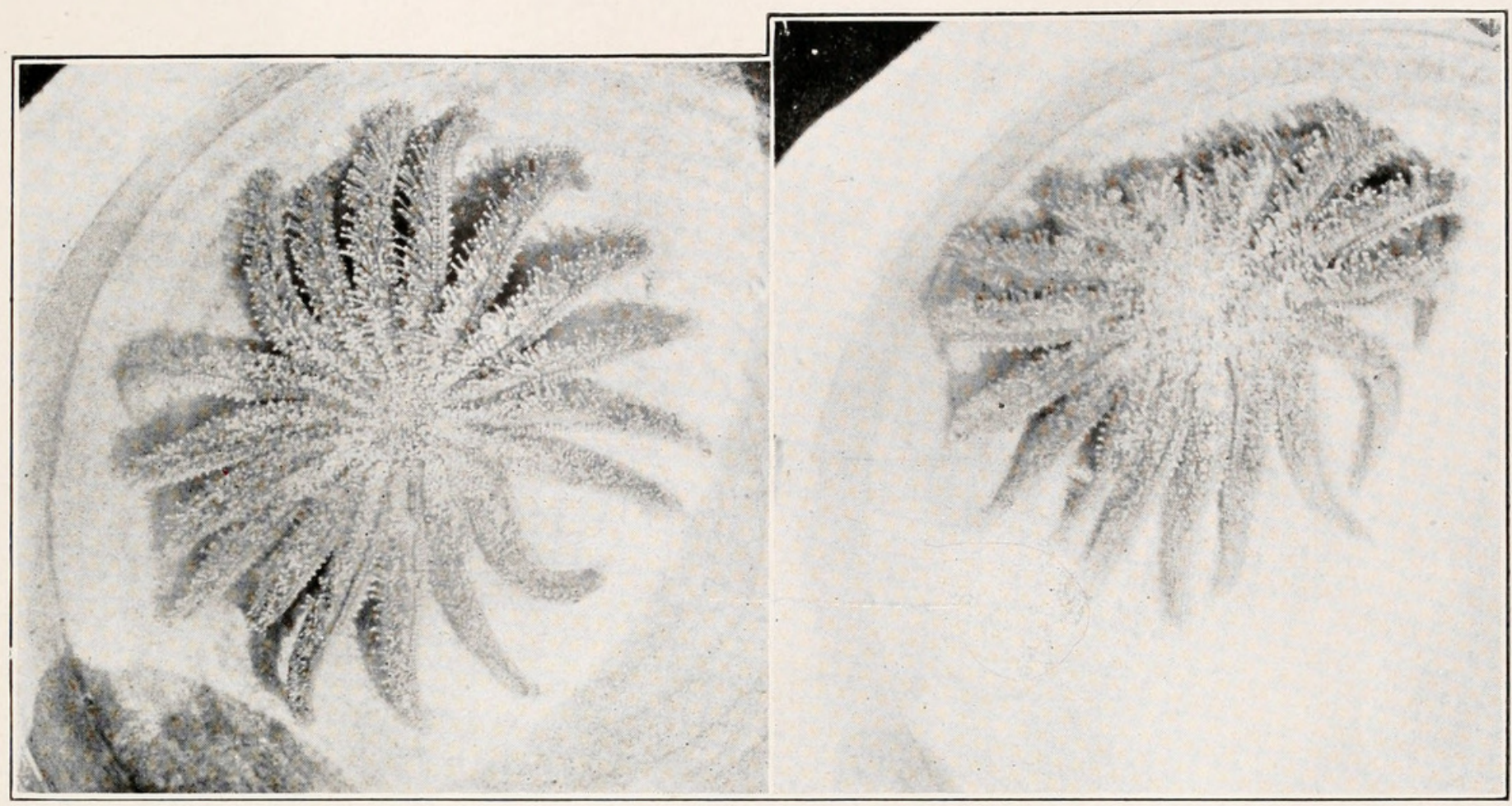

FIG. I.

FIG. 2.

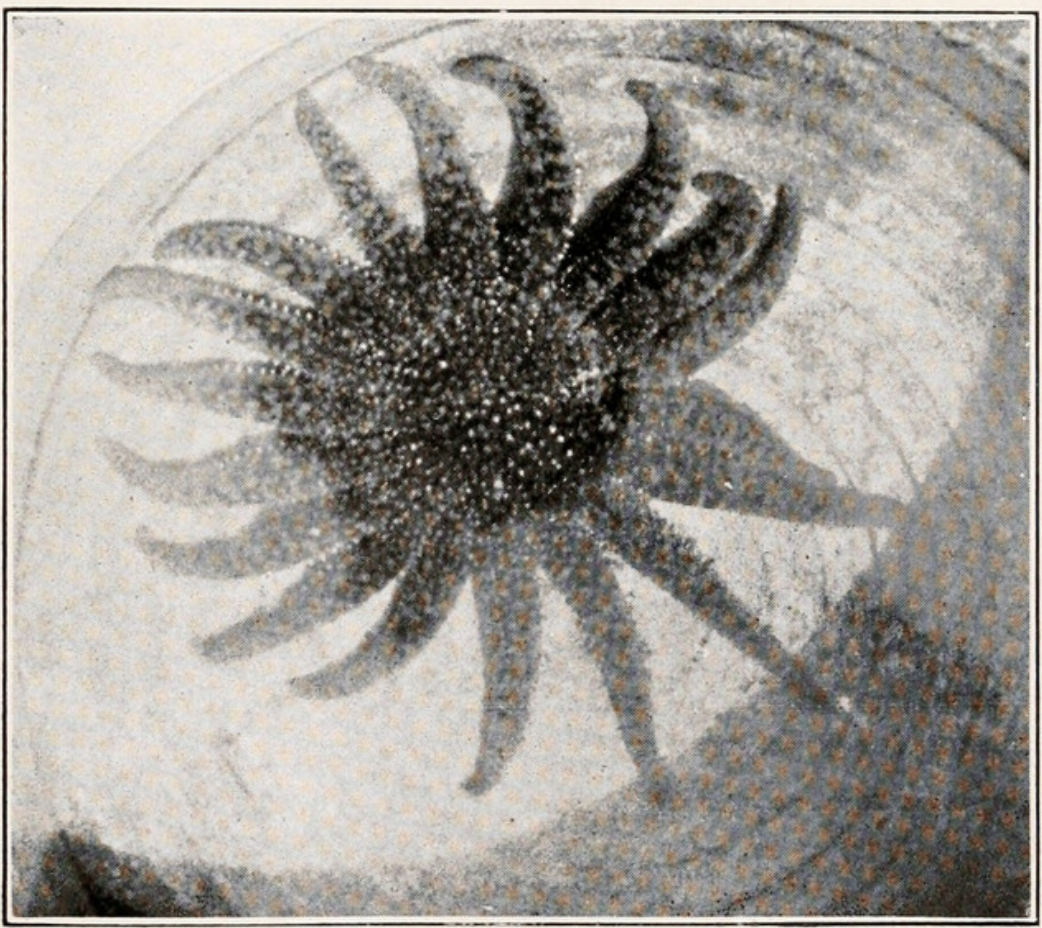

FIG. 3. 



\section{BIOLOGICAL BULLETIN}

\section{EXPERIMENTS ON THE DETERMINATION OF THE FATE OF THE GRAY CRESCENT MATERIAL \\ IN THE FROG EGG.}

W. C. GEORGE,

Department of Biology, Princeton University

In the latter part of March of this year I began a series of experiments at Princeton University, having for my aim the determination of the location of the organ-forming substances, if such exist, in the cytoplasm of the frog egg. The work is scarcely more than begun and I should not ordinarily venture to present my results in such an incomplete form, but since I am leaving Princeton to enter army work it seems advisable to give a preliminary account of such results as I have obtained thus far. I hope to be able to do further experiments at a later time and to publish a full account with figures.

The method used in these experiments was to inject small amounts of a three-fourths of one per cent. aqueous solution of trypan blue, a colloidal vital (?) stain, into the cells of the early cleavage stages of the egg and into certain regions of the young blastula. Injections were made under a binocular dissecting microscope by means of exceedingly fine pointed glass pipettes in which the large upper end was sealed. By warming the upper end of the pipette part of the air would be driven out and during cooling a quantity of the stain could be sucked in. On rewarming, the stain would be forced out in a steady flow and by inserting the needle into the cell or region that I desired to inject a small amount of the stain would be left in the egg.

Since no sections have been made as yet I cannot give any report in regard to the distribution of the stain to the daughter cells in those cases where the presence of the stain or the mechan- 
ical injury did not prevent further segmentation. I observed, however, that the presence of the stain induces a moribund condition which results sooner or later in the death of the cell injected or of the cells arising from it. I therefore used this method in the following experiments to kill certain regions of the egg, considering it preferable, since it can be better controlled, to the usual method of pricking with a hot needle.

\section{Experiments With EgGs of Rana sylvatica.}

On the morning of March $26 \mathrm{I}$ brought into the laboratory a quantity of $R$. sylvatica eggs in the gray crescent stage. In nineteen of these eggs I injected one of the cells of the two-cell stage. In sixteen of the nineteen the first cleavage had come in along the median plane of bilateral symmetry, dividing the egg into right and left halves. In eight of these eggs I injected the right-hand cell and in eight the left. In one egg the first cleavage plane was oblique to the anterior-posterior axis. Whether or not the injected cell in this case contained the greater or the less amount of the gray crescent was not noted. In the other two eggs of the nineteen the first cleavage plane was transverse to the median axis, thus dividing the egg into anterior and posterior halves. In one of these two eggs I injected the anterior cell, which contained the gray crescent material, and in the other I injected the posterior cell leaving the cell containing the gray crescent material uninjured. The morning of March 28, two days after the injections had been made, I found in the egg in which the posterior cell had been killed by injection, that the anterior cell containing the gray crescent material remained uninjured and had developed into an embryo with neural folds uplifted and lying alongside the dead material resulting from the injected cell. None of the other eggs either at this time or later showed any thing resembling a neural plate. They formed a cap of live cells on a mass of dead material but developed no further.

On the morning of April I I collected eggs of $R$. sylvatica in the early blastula stage. The gray crescent material could still be distinguished by the characteristic pigmentation and by the smaller size of the cells there as compared with other regions 
at the margin between the yolk and pigmented hemispheres. I injected the stain into ten of these blastulas, inserting my needle at right angles to the axis of the egg through the gray crescent material in such a way as to destroy nearly all of the material in that region. In eight other eggs I made a similar injection on the opposite side of the yolk field. Examination of the uninjured control eggs on the afternoon of April 3 showed them to have developed into embryos with external gills appearing. Except in two cases where there were structures which might possibly have been incomplete transverse cerebral commissures, there was no evidence of anything like a neural plate in any of the ten eggs having all or most of the gray crescent material destroyed. Closure of the blastopore was interfered with in these eggs, but apparently little if any more so than in those eggs in which the injection was made on the side of the yolk hemisphere opposite the gray crescent and from which I obtained seven neurulas out of a lot of eight eggs. The eggs with the gray crescent material destroyed were kept until the afternoon of April 4th when they were preserved, no neural plate or folds having been formed in any of them.

\section{Experiments with Eggs of Rana pipiens.}

The morning of April 5 I collected eggs of $R$. pipiens and brought them into the laboratory as they were passing into the two-cell stage. In forty-six of these eggs in which the first cleavage plane was anterior-posterior I injected one of the first two lateral cells. Of eight eggs in which the first cleavage plane was transverse to the anterior-posterior axis I injected the anterior cell in four eggs and the posterior cell in the other four. On account of the moribund condition resulting from injection none of the eggs injected at the two-cell stage developed far enough to give any information in regard to the fate of the gray crescent. I shall not therefore give their history here.

From eggs injected at the four-cell stage I obtained more definite results. From fourteen eggs having one of the two posterior cells of the four-cell stage injected I later obtained ten embryos defective on one side of the blastopore but having complete neural tubes. 
I injected the anterior cell in four eggs in which the first two cleavage planes were oblique to the anterior-posterior axis of the egg, giving a four-cell stage with an anterior cell containing a large part of the gray crescent material, two lateral cells each containing a small amount of the gray crescent material, and a posterior cell containing none. Observation of the surface showed that though the presence of the stain did not prevent further segmentation of the injected cell, it brought about a moribund condition of the cells arising from it which prevented their taking part in development beyond the blastula stage. In three of these eggs no blastopore closure occurred though the potential blastopore was marked out by a pigmented line. In the fourth egg partial closure of the blastopore did occur and in the process the dying material, which consisted of a piece about one fourth the size of the egg, was pinched off and left free in the perivitelline space. I kept this egg under observation until the fourth day after injection but it never developed any structure that had the slightest resemblance to a neural plate though at the time of preservation it had had cilia on the surface for more than twenty-four hours and the control eggs had developed into curved embryos.

Furthermore, from eggs in which I succeeded by injection in bringing about the death of the two posterior ventral cells of the eight-cell stage I obtained a high percentage of neurulas while, on the other hand, from eggs in which I killed the two anterior ventral cells, which contained most of the gray material, I obtained no neurulas.

Further evidence that the gray crescent forms the nervous system was obtianed by making injections into young blastulas of $R$. pipiens in a manner similar to that described for $R$. sylvatica. In nine young blastulas I killed all or most of the gray crescent material by making transverse injections through the gray crescent region or by two or three radially directed injections. In five of these eggs development did not proceed beyond early gastrulation, but in four of them partial overgrowth of the yolk by the blastopore lips took place. In the process the plugs of dead material around the injected points were squeezed out of the egg into the perivitelline space. I kept these for five and 
one half days after laying (until the tadpoles from the control eggs had come out of the jelly) but though they developed surface cilia and seemed to be composed of perfectly healthy tissue, they never developed any semblance of a nervous system.

I likewise destroyed the material in the region of the lower hemisphere opposite the gray crescent in twelve eggs of the same lot. Development proceeded beyond the blastula stage in only six of these but from all six of them neurulas resulted.

All of these experiments indicate that the material of the gray crescent gives rise to the neural plate.

Princeton, N. J.,

April I5, I918. 


\section{FURTHER EXPERIMENTS ON THE EFFECT OF HEAT ON THE EGGS OF CUMINGIA.}

MARGARET MORRIS HOSKINS,

University and Bellevue Hospital Medical College.

I. Introduction.--If the eggs of the mollusc Cumingia tellinoides are heated during the prophase of the first maturation division, the formation of the polar body is prevented. The nuclear division continues, giving rise to two daughter nuclei, both of which are retained in the egg. In the unfertilized egg these nuclei fuse, so that the egg is in fact fertilized by the polar nucleus. The course of the development which follows this self-fertilization has already been described (Morris, 'I 7 ). Since the publication of that study, experiments similar to those producing artificial parthenogenesis have been made on fertilized eggs. It was found that if eggs are heated immediately after insemination they do not form polar bodies, but proceed to the first cleavage at the end of the warming. As these eggs should contain a triploid instead of a diploid number of chromosomes, it was thought that a study of them and a comparison with dispermic eggs might yield interesting results. Theoretically, of course, the polar nucleus is equivalent to a sperm nucleus, and either of these is equivalent to the egg nucleus. The suppression of maturation gives a chance for an interesting comparison between the sperm and polar nuclei. Besides the experiments in which maturation was suppressed, a control series of experiments was made to distinguish the effects of heating from those of the retention of the polar nucleus. In this series, the fertilized eggs were heated after they had completed the formation "of polar bodies. Any abnormalities found in these eggs would obviously be the result of the heat alone.

A cytological study of eggs from the different sets of experiments has been made and is presented in the following pages.

II. Material and Methods.-The technique of the experiments is extremely simple and hardly varies at all from that used in 260 
producing artificial parthenogenesis. A small flask of sea water is partially immersed in a beaker of water, and warmed over a flame. The eggs are put into this flask, and can easily be kept at any desired temperature for an hour or more. The temperature most frequently used was that which had been most success$\mathrm{ful}$ in inducing parthenogenetic development, $32^{\circ}$ to $34^{\circ} \mathrm{C}$. The length of the exposure was different, however, for while the unfertilized eggs are not injured by being kept at this temperature for sixty, or even ninety minutes, the fertilized eggs appear more sensitive and should not be heated for more than thirty-five or forty minutes. In one series of experiments the eggs were placed in the warm water within five minutes after insemination; in the others they were watched until maturation was complete, and transferred to the flask before the pronuclei had united.

Eggs were preserved from the various experiments at different intervals, and a large amount of normal material was also preserved. Bouin's fluid was used as a fixative and the eggs were embedded in paraffin in the usual way. The sections were cut ten microns in thickness and stained with iron hematoxylin.

III. Cytological Study.-A few points in the normal and parthenogenetic development of Cumingia should be reviewed here for the sake of clearness. The haploid number of chromosomes is eighteen; they are very distinct in the first maturation spindle. There is no reason to suppose that the exact diploid number is not present in the first cleavage spindle of normally fertilized eggs, but owing to the form of the chromosomes, accurate counting is impossible. The long thin threads are so much intertwined, that individuals cannot be distinguished. In the parthenogenetic egg, however, the case is different. Here the chromosomes of the first cleavage are small and very definite bodiesand it is possible to count them. Since the chromatin of the egg has not undergone reduction, one would expect to find thirtysix chromosomes in the first cleavage. Such is not the case, however; the number is variable, but always greater than thirtysix. Fifty to sixty of these small masses of chromatin are present, and it is evident that they do not represent individuals of the normal chromosome group. Under the experimental conditions a new distribution of the chromatic material has taken place, 
and an abnormal number of chromosomes is formed. It is not possible to determine whether the mass of chromatic material rep esented in one of these plates of chromosomes is exactly equal to that of a normal cleavage plate, but on theoretical grounds it was assumed that such is the case.

(b) Suppression of Maturation in Fertilized Eggs.-As has been said the fertilized eggs in which maturation is to be suppressed are heated within five minutes after their insemination. At this time, the polar spindle has moved to the periphery of the egg, but the formation of the polar body itself has not begun. The sperm head is within the egg, but has not been transformed into a vesicular pronucleus. The first stage that is of interest in eggs preserved from these experiments is the anaphase represented in Fig. I. In this it will be seen that a division of the eighteen bivalent chromosomes has taken place, and that the daughter chromosomes are moving somewhat irregularly to the poles of the spindle, while the sperm head is beginning to enlarge to form a vesicle.

A later stage of this nuclear division is shown in Fig. 2. Here the chromosomes have begun to form vesicles preparatory to passing into the resting stage. It will be seen from Fig. I that although the division of the chromosomes is complete, the migration of the daughter chromosomes to the poles of the spindle is somewhat irregular, and it is owing to this fact that we do not find two perfectly definite groups of vesicles in such a stage as Fig. 2 represents. In this figure the male pronucleus is also to be seen; it is well advanced in its development, and apparently has not been injured by the heat.

Further development of the resting nuclei is seen in Fig. 3. Here two daughter nuclei are found, with a third small vesicle which would undoubtedly have fused ultimately with them, as there is no evidence that any such vesicles are ever left out. In this stage the male pronucleus had developed still farther, and it is probable that the aster represented in the figure is of male origin.

Fig. 4 represents the final stage of the suppression of the polar body. In this, the two daughter nuclei formed from the chromosomes of the polar spindle have fused completely. The male pronucleus has reached a large size and lies closely apposed 
to the egg nucleus. The aster has already divided and the spindle is forming before the male and female pronuclei have fused. In some cases, apparently, the pronuclei do not unite at all; and one finds such a prophase of the first cleavage as that represented in Fig. 5. Here two skeins of chromatin are present in the spindle, and the figure shows what it is important to note, namely, that even if the pronuclei do not unite before cleavage, all chromatic material is included in the formation of the chromosomes of the first cleavage spindle.

We can trace, then, in eggs which have been heated immediately after fertilization, a suppression of maturation which leads to the formation of two daughter nuclei within the egg. Further, we can trace the union of both these nuclei with the male pronucleus, leading to the formation of a cleavage spindle which should contain eighteen chromosomes from the sperm and thirty-six from the egg. This suppression of maturation is exactly like the process which has been seen to take place in the unfertilized eggs, in which, owing to the absence of the sperm, the result is a diploid instead of a triploid amount of chromatin.

(c) The First Cleavage of Heated Eggs.-The first cleavage spindle forms normally in the eggs which have been heated immediately after insemination. Before its formation the eggs have been returned to cooler sea water, so that conditions surrounding them are normal during the division. The important variation from the usual condition is seen in the chromatic part of the figure. Theoretically, of course, there should be fifty-four chromosomes, but as a matter of fact there are sometimes fewer, sometimes more than this number. Figs. 6 to 9 show plates of chromosomes from such eggs, in which the numbers are 44,48 , 50 and $6 \mathrm{I}$, respectively.

It is in a comparison of these plates with those from parthenogenetic, normal and dispermic eggs that the greatest interest is to be found. The equatorial plates of the first cleavage of normal eggs show how much the form of the chromosomes is modified by the experimental treatment. In the normal eggs (Figs. Io and II), one finds long threads so much twisted about each other that accurate counting of them is impossible. This is the case also in the dispermic egg, as shown in Fig. I2. It is evident that 
more chromosomes are present here than in the normal egg, but the exact numerical relations cannot be determined. The most interesting comparison to be made is with the parthenogenetic egg. Here, as has been said, the chromosomes are so distinct that they can be counted, and the number is about the same as that found in fertilized eggs in which the polar bodies have been suppressed. Figs. I3 and I4 are from the first cleavage of parthenogenetic eggs, in which the numbers of the chromosomes are 46 and 47 respectively. In other cases as many as sixty-one chromosomes have been found (Morris, 'I7). The general shape of the bodies is similar in parthenogenetic and in heated fertilized eggs; spherical bodies and short thick rods are found instead of the normal threads. A striking difference is seen, however, in the size of the individual chromosomes, which is considerably greater in the fertilized than in the parthenogenetic egg. This is most clearly respresented in text-figure $\mathrm{I}$, in which the chromosomes are arranged in rows, graded according to size. $A$ represents the chromosomes of the parthenogenetic egg, $C$ those of the fertilized egg in which maturation has been suppressed. The smallest members of the two groups are about equal in size, but almost half of those in the fertilized egg are larger than the largest from the parthenogenetic one. A natural explanation of this difference in size is suggested by the fact that while the suppression of the polar body gives the parthenogenetic egg a diploid amount of chromatin, the same process makes the fertilized egg triploid. As the number of chromosomes is the same in the two cases, we might expect their size to be greater in the egg that contains the larger amount of chromatin. This was, in fact, the explanation given in a preliminary report (Morris, 'I 7 ), but further experiments have shown that it is not entirely correct.

A control series of experiments was made in which eggs were subjected to heat after the formation of the polar bodies had been completed. In these, the effects of heat are shown, separated from any effect of the retention of the polar nucleus. The comparison of the parthenogenetic eggs with those that have been fertilized and heated before maturation leads one to expect that eggs heated after maturation will show cleavage chromosomes exactly like those of parthenogenetic egg, since both are 
diploid and have been exposed to heat. When, however, examination of the preserved material is made, an unexpected condition is found. As in other eggs which have been heated, the chromosomes are fifty-five to sixty-five in number, but instead of being like those of the diploid parthenogenetic egg in size, they are not to be distinguished from those of the triploid egg. The reader is referred again to text-figure $I$ in which the nuclear condition of the three kinds of eggs is shown. $A$ is the parthenogenetic egg with thirty-six chromosomes incorporated into its cleavage nucleus, $B$ the normal one also containing thirty-six, and $C$ the triploid egg with fifty-four chromosomes. The range of size of the chromosomes is about the same in both kinds of fertilized eggs $(B$ and $C$ ) notwithstanding the different amounts of chromatin present in them. Plates of the eggs heated after maturation are shown in Figs. I5, I6 and 17 , the numbers of the chromosomes being 55, 65, and 66 respectively.

(d) The Value of the Polar Body. - The unexpected size relation of the cleavage chromosomes suggests the possibility that the chromatin of the polar nucleus is not, as a matter of fact, active. If that were the case, the parthenogenetic egg would be actually haploid, and both fertilized eggs diploid, and this would explain the condition illustrated in the text-figure. It must be remembered, however, that the polar nucleus is like the egg nucleus in appearance, and that the two vesicles fuse without any evidence of elimination of nuclear material. Dead chromatin is sometimes found in the cytoplasm of other kinds of eggs under abnormal conditions, but no such masses of chromatin are found in the material preserved from these experiments. Since this is so, it is difficult to believe that the polar nucleus, which was formed from perfectly normal daughter chromosomes, suffers complete degeneration. This is especially true when one reviews the experiments (Morris, 'I7) by which it was shown that the retention of the polar nucleus in unfertilized eggs is followed by normal cleavage; while those eggs from which it is extruded are unable to develop.

Study of the later stages of the development of heated eggs confirms the belief that the polar nucleus is an active element in 
development. In the cleavage which occurs about three hours after fertilization, one finds that the chromatin has returned to the normal condition. The number of the chromosomes can no longer be distinguished accurately, as they are small and crowded
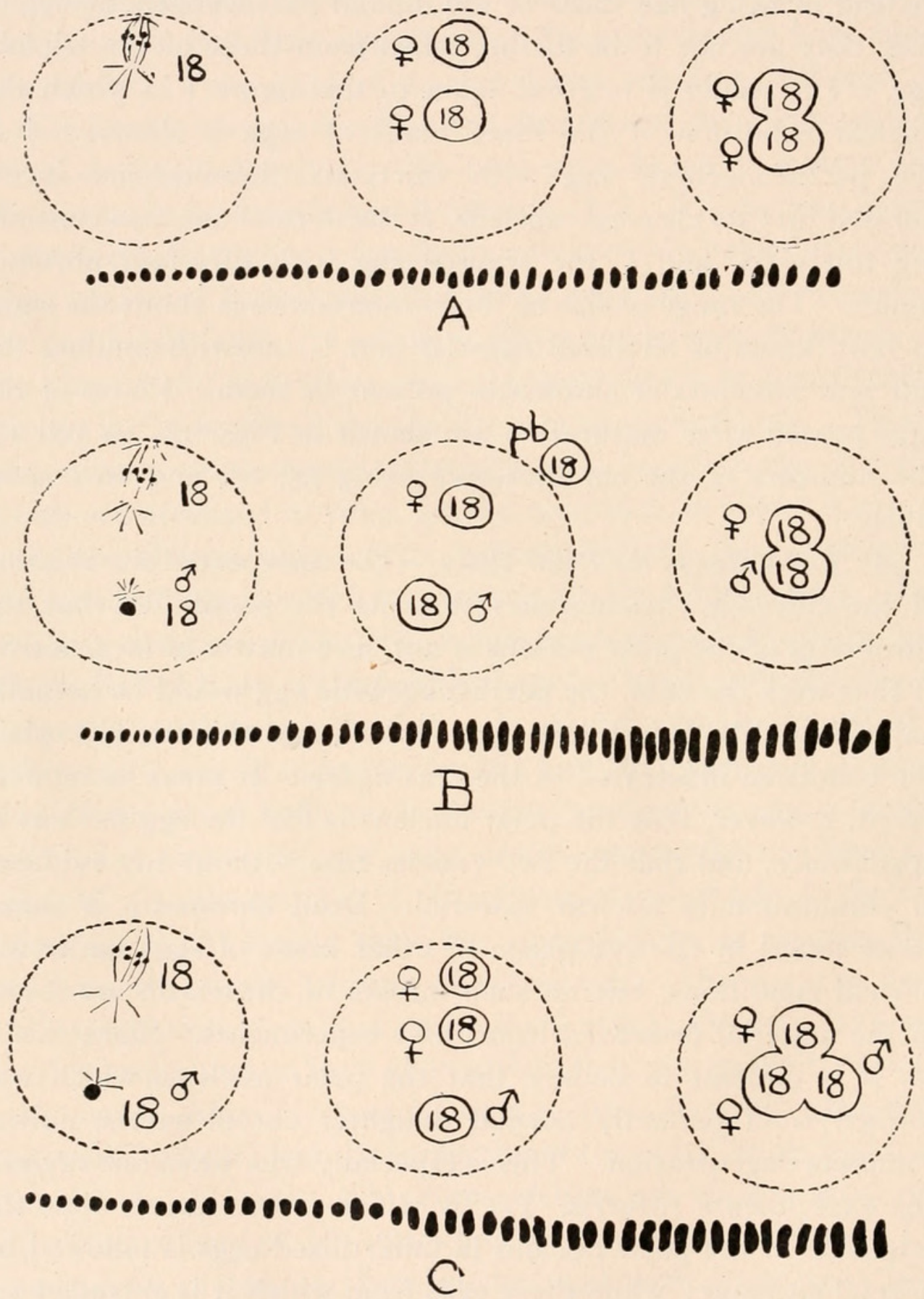

FIG. I. Diagrams showing the nuclear conditions and the chromosomes of eggs heated at different periods. $A$, heated before fertilization (parthenogenetic); $B$, heated after fertilization and maturation; $C$, heated after fertilization and before maturation. 
together in the spindle. Fig. 18 is from a fertilized egg in which maturation has been suppressed, Fig. I9 from a normal one, and Fig. 20 from one which was heated after its polar bodies had been formed. A comparison of the three figures shows that there are approximately the same number of chromosomes in the plates represented in 19 and 20 , while 18 shows a larger number. This is in accordance with the belief that the polar nucleus contributes normal chromosomes to the egg.

Further evidence is given by a study of the resting nuclei. Boveri ('05) has shown that the surface area of a resting nucleus is proportional to the number of chromosomes in it, and this fact is frequently used in determining the relative amounts of chromatin when the cleavage chromosomes cannot be counted. In the present instance, the four cell stage of the various types of egg has been selected for comparison. Here we can be sure of comparing equivalent nuclei, as the size and position of the cells makes them easily recognizable. It will be remembered that the cleavage in Cumingia is not equal. The first division separates a small cell $A B$ from a larger one, $C D$. Then follows a division of $A B$ giving rise to a three-cell stage; and next $C D$ divides. In the four-cell stage $A, B$ and $C$ are approximately equal, while $D$ is larger than any of them. In the normal egg, shown in text-figure $2, A$, the nuclei of all four cells are equal. Fig. 2, $B$, shows a parthenogenetic egg, with nuclei like those of the normal one; and such nuclei are also found in eggs heated after maturation, as shown in Fig. 2, C. All these eggs contain the diploid amount of chromatin, which is not actually changed by the heating, and, as far as can be judged from the resting nuclei, the chromatin supplied by the polar nucleus is equivalent to that supplied by the sperm. Similarity is also found among triploid eggs, whether these contain an extra sperm or a suppressed polar nucleus. Text-figure $2, D$, shows a dispermic egg with two multinucleate cells and one nucleus abnormally large. Text-figure 2, E, represents a fertilized egg in which the polar nucleus was retained; here also are two multinucleate cells. In $F$ which is from an egg of the same sort, the cells are not multinucleate, but two of the nuclei are above the normal size.

(e) The Size and Number of the Chromosomes.-From the 
evidence given above I believe we may conclude that the parthenogenetic egg contains a diploid amount of chromatin, while the fertilized egg in which maturation has been suppressed is triploid. It is evident then that the size of the chromosomes in heated eggs is determined by some other factor than the amount
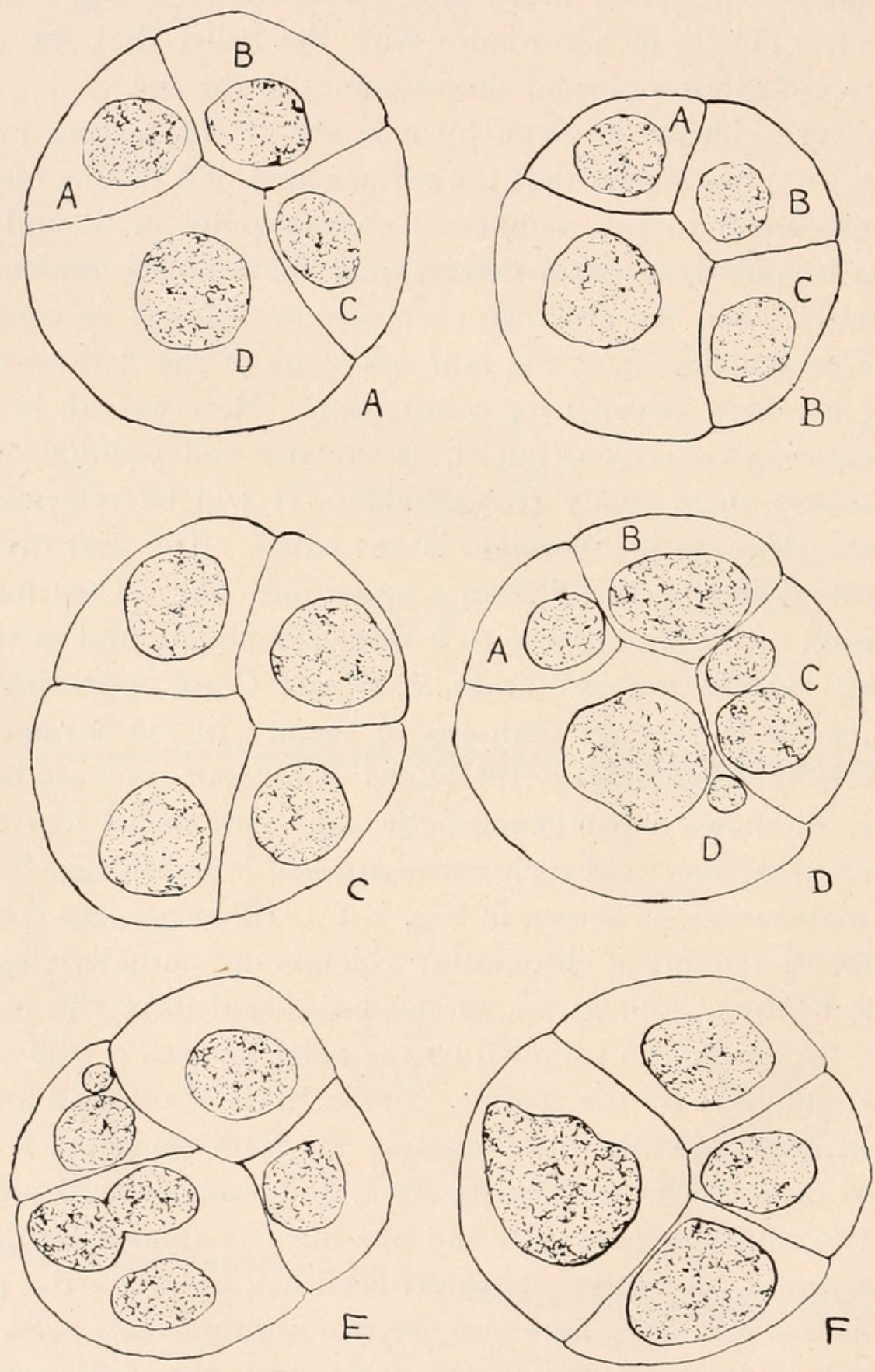

FIG. 2. $A$, normal egg (diploid); $B$, parthenogenetic egg (diploid); $C$, fertilized egg heated after maturation (diploid); $D$, dispermic egg (triploid); $E$ and $F$, fertilized egg heated immediately after insemination (triploid). 
of nuclear material that is present in them. If this were not so, the chromosomes of the fertilized egg heated after maturation would be like those of the parthenogenetic egg, instead of like those of the triploid one. Various other facts indicate that the appearance of these equatorial plates is not a reliable measure of the amount of chromatin present. Compare, for instance, Figs. I5 and I7. There are ten more chromosomes in the second plate than in the first, but the increase in number has evidently not been accomplished by the subdivision of some members of the first group for the average size of the bodies is greater in the plate which contains the larger number. Compare Fig. I7 with Fig. Io also. Fertilization and maturation were normal in both these eggs, so that they undoubtedly contained the same amount of chromatin, but it seems as if there were more in the figure from the egg which has been heated. There is, in fact, no increase in amount, for in later stages the chromatin returns to the normal condition (Figs. I9 and 20).

Apparently, in heated eggs, we have an abnormal condition of aggregation of the chromatin, varying somewhat in individual cases. The variations observed in the number and size of the chromosomes are due to differing degrees of susceptibility to heat on the part of the eggs. When the susceptibility is slight, there is an increase in the number of bodies formed from the chromatin; when it is greater, there is an apparent increase in the amount of this material. It may be noted that the slighter abnormality is found in eggs heated before fertilization. At this period few eggs are destroyed by the heat, even if the exposure is prolonged to ninety minutes. After fertilization and maturation have taken place, it is difficult to warm the eggs for even thirty minutes without killing a large number; and it is in the chromosomes of these eggs that the greatest degree of abnormality is observed.

\section{Discussion.}

In I9Io, Jordan studied the normal cytology of Cumingia, and concluded that in this animal the chromosomes are not persistent and individual cell organs. He based his conclusion on two facts; first, that they cannot be followed through the resting stage of the cell cycle; and second, that they undergo 
changes of form during the development of the egg. At first sight, the evidence given in this paper seems to agree with Jordan's conclusion. If the persistence or recurrence of a definite group of chromosomes at each mitosis is essential to proving them individuals, the bodies in Cumingia cannot be so designated, since an entirely abnormal arrangement of the chromatin may be substituted for the usual group without injury to the egg. This use of the word "individuality" (implying unity and a separate, definite existence) has been made by many writers, and has led to much argument and confusion. It is not, however, the sense, in which all supporters of the theory of the individuality of the chromosomes have applied it. As McClung ('I 7 ) for instance, uses it, it means that each chromosome is qualitatively different from the others in the group- "a single thing of a given kind." The essential point is that the chromatin is "differentially organized and linearly arranged," and the chromosomes are aggregates of this substance, individual in the sense that they have specific characters. This theory is broad enough so that Hance's work (I9I8) really supports it. Hance finds, both in Enothera scintillans and in the pig, certain fragmented chromosomes. The parts of chromosomes behave like normal bodies in the various stages of mitosis, and such facts would be in opposition to the narrower view of the individuality of the chromosomes. Hance, concludes "If the theory of the individuality of the chromosomes can only recognize a strict morphological continuity then the chromosomes in Scintillans lose their individuality through breaking up. If the theory is broader in its scope and admits an individuality not only of whole chromosomes, but of the chromatin or chromomeres, the scintillans situation falls within its limits."

The conditions found in Cumingia give no information with regard to the organization of the chromatin or the individuality of chromomeres. All that can be established from them is that the aggregation of the chromatin into definite bodies is subject to a certain amount of variation under normal conditions, and to very great alterations under the influence of heat. This behavior is entirely consistent, so far as I can see, with the belief that the chromatin is definitely organized and that the normal chromo- 
somes are qualitatively different from each other. On the other hand the facts are not incompatible with the opposing view that the chromatin is a homogeneous substance, which condenses at mitosis into masses devoid of individuality.

\section{Summary.}

I. If the eggs of Cumingia are subjected to heat immediately after fertilization, they do not form polar bodies. The chromosomes of the first polar spindle divide and two resting nuclei are formed. These nuclei fuse with each other and with the male pronucleus, giving rise to a cleavage nucleus which contains a triploid amount of chromatin.

2. The equatorial plates of these eggs show forty-five to sixty chromosomes. About the same number has been found in the cleavage of parthenogenetic (diploid) eggs; but there the individual bodies are smaller than they are in the triploid eggs.

3. If fertilized eggs are heated after they have formed polar bodies, the equatorial plates of their first cleavage contain fiftyfive to sixty-five chromosomes. These are equal in size to those of a triploid egg.

4. Study of later stages (resting nuclei and equatorial plates) shows that the chromatin of the polar nucleus is active, and approximately equivalent to that of a male pronucleus.

5. The size and number of the chromosomes in heated eggs is not dependent on the amount of chromatin that is present. They vary with the susceptibility of the egg to heat.

6. The conditions described are not in opposition to the theory of the individuality of the chromosomes, if that theory is given a broad interpretation.

Boveri, Th.

\section{BIBLIOGRAPHY.}

'o5 Zellen Studien, V. Jena, I905.

Hance, Robert T.

'r8a Somatic Chromosome Variations in the Evening Primrose. Enothera scintillans. Genetics.

'r8b The Diploid Chromosome Complexes of the Pig (Sus scrofa) and Their Variations, Jour. Morph., Vol. 30, No. I.

Jordan, H. E.

'ro A Cytological Study of the Egg of Cumingia with Special Reference to the History of the Chromosomes and the Centrosome, Arch. fur. Zellforsch., Vol. 4. 
McClung, C. E.

'r7 The Multiple Chromosomes of Hesperotettix and Mermiria (Orthoptera). Jour. Morph., Vol. 29, No. 2.

Morris, Margaret.

'r7a A Cytological Study of Artificial Parthenogenesis in Cumingia, Jour. Exp. Zoöl., Vol. 22, No. I.

'r $7 \mathbf{b}$ Influence of Heat on the Eggs of Cumingia, Proc. Am. Assoc. Anat. Anat. Rec., Vol. I I, No. 6. 



\section{EXPLANATION OF PLATE I.}

All the figures on this plate are from fertilized eggs, heated immediately after insemination,

FIG. I. First polar, spindle, anaphase, male pronucleus at the left.

FIG. 2. First polar, spindle, telophase. Male pronucleus at the right.

FIG. 3. Daughter nuclei from maturation division, male pronucleus below.

FIG. 4. Diploid female pronucleus and normal male pronucleus uniting.

FIG. 5. Prophase, first cleavage. 

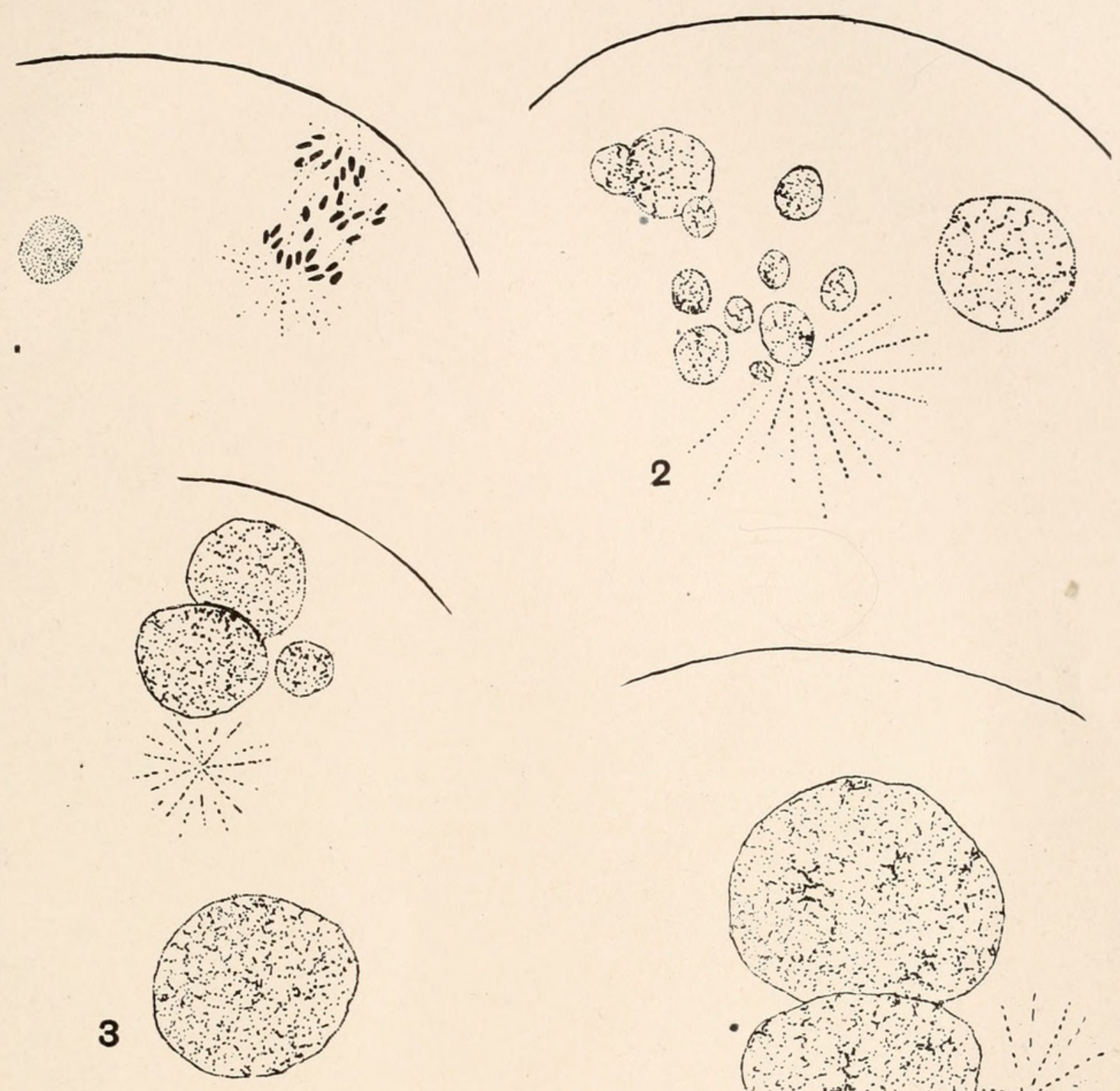

2
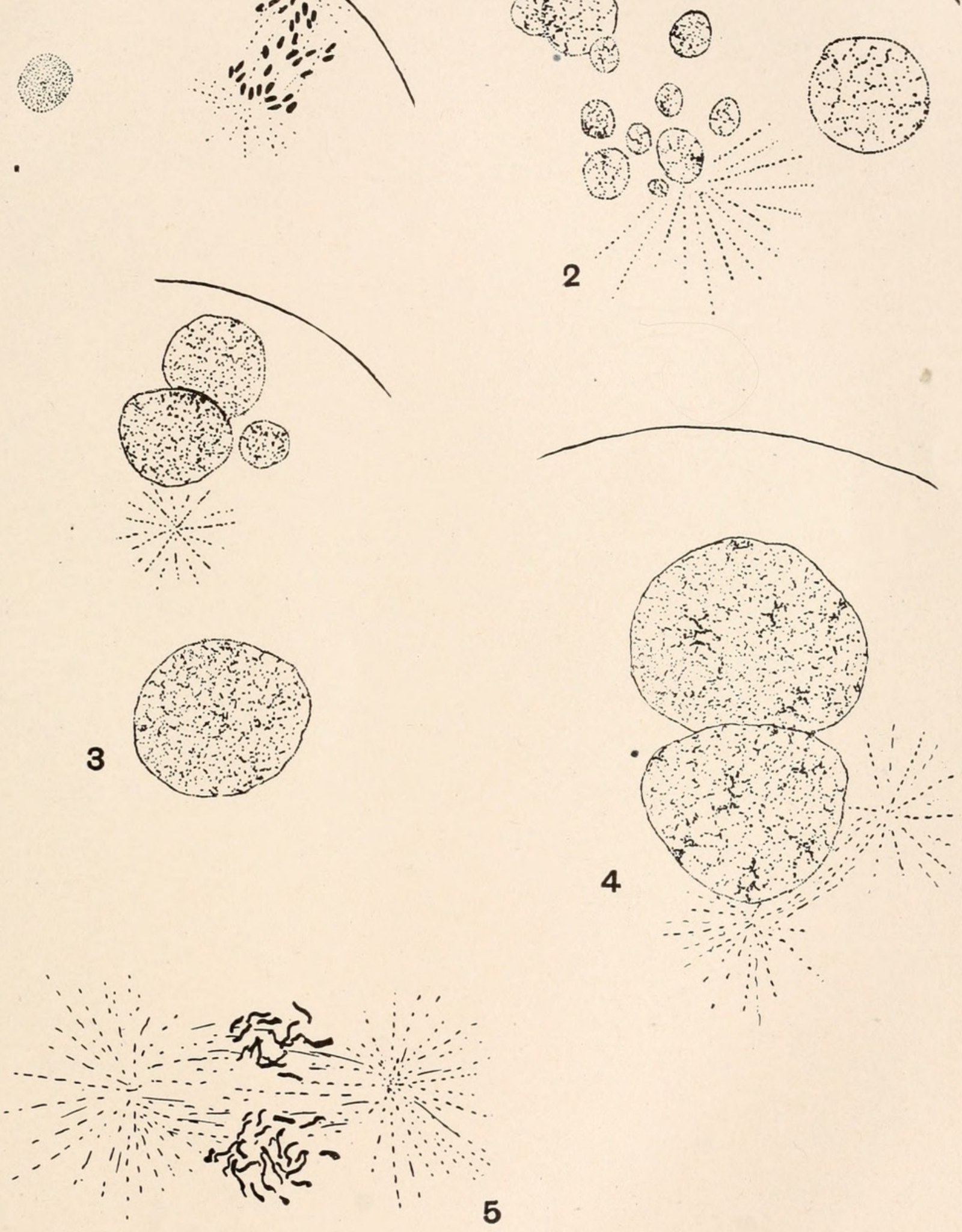




\section{EXPLANATION OF PLATE II.}

FIGs. 6, 7, 8, 9. Equatorial plates of first cleavage of eggs, heated immediately after insemination (triploid).

Figs. IO, II. Chromosomes from first cleavage of normal eggs.

FIG: I2. Chromosomes from first cleavage of dispermic egg.

FIG. I3, I4. Equatorial plates of first cleavage of parthenogenetic eggs (diploid).

FIGs. I5, I6, I7. Equatorial plates of first cleavage of eggs heated after maturation was completed (diploid).

FIG. I8. Chromosomes from an egg heated immediately after insemination. Egg preserved three hours after fertilization.

FIG. I9. Chromosomes from a normal egg, preserved three hours after fertilization.

FIG. 20. Chromosomes from an egg heated after maturation was completed. Egg preserved three hours after fertilization.

FIG. 2I. First cleavage (anaphase) of an egg heated after maturation was completed. 

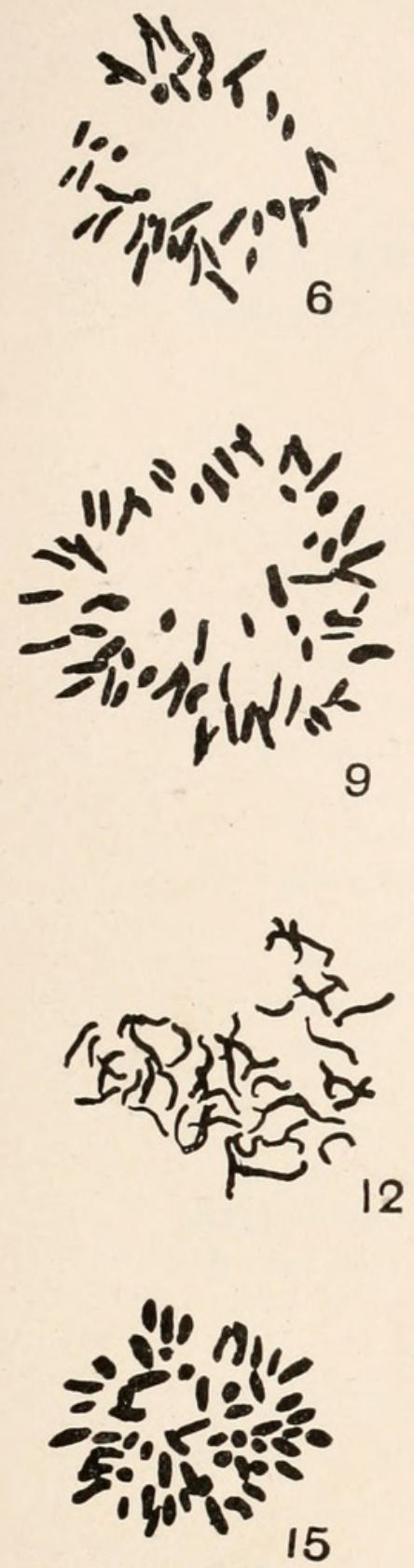
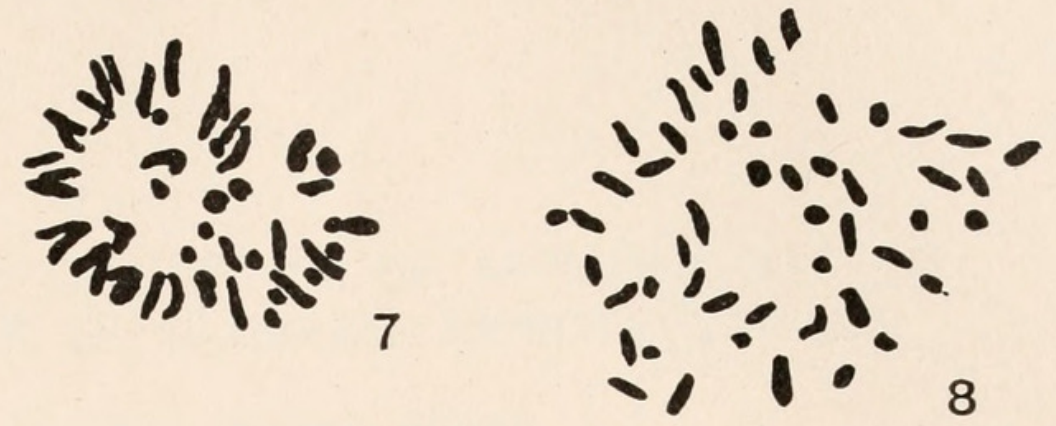
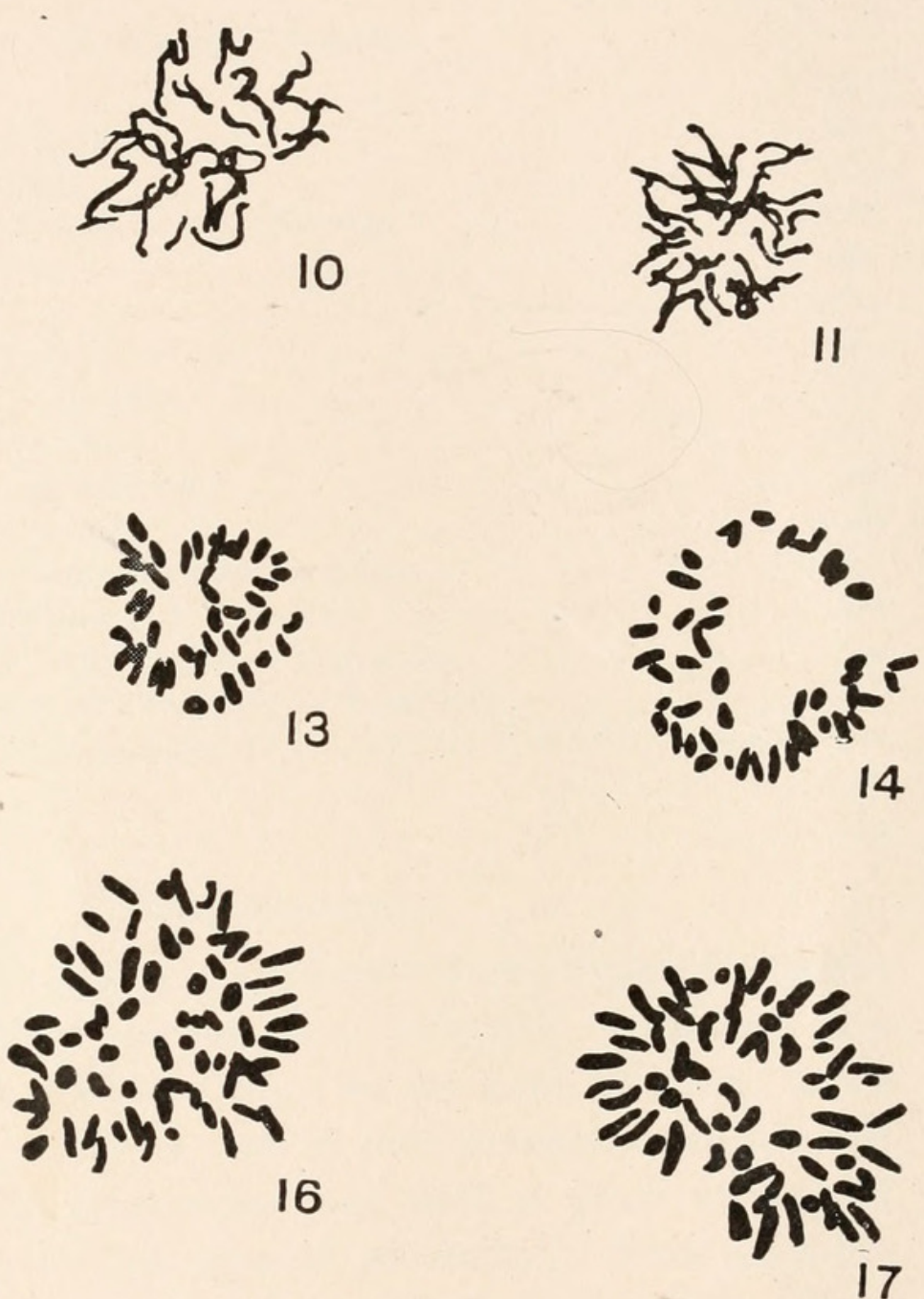

18

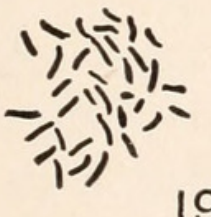

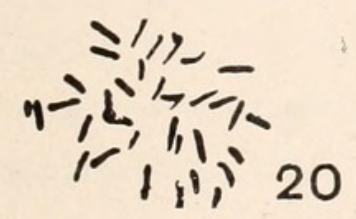

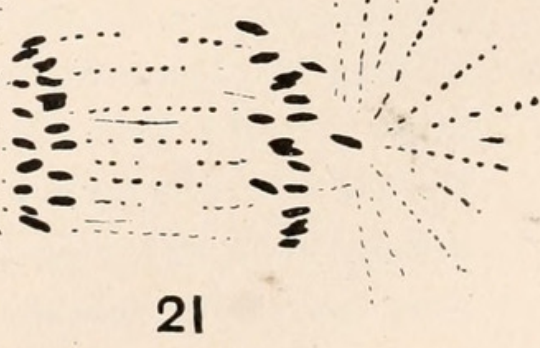





\title{
AN EXPERIMENTAL STUDY OF ACCLIMATION TO TEMPERATURE IN PLANARIA DOROTOCEPHALA.
}

\author{
ELLINOR HELENE BEHRE.
}

TABle of Contents.

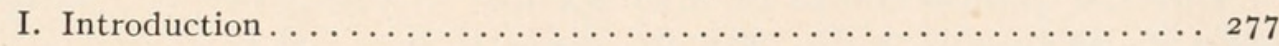

Summary of the Literature. . . . . . . . . . . . . 277

Purposes of the Paper ......................... 279

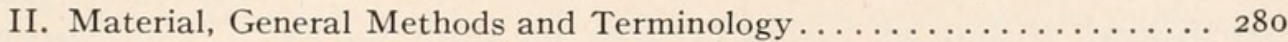

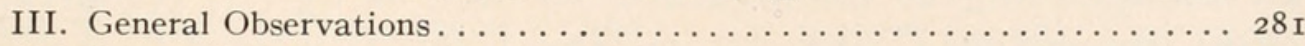

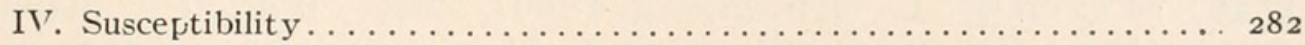

A. Jong Time Acclimation. . . . . . . . . . . . 284

B. Short Time Acclimation . . . . . . . . . . . . . 287

V. Carbon Dioxire Production . . . . . . . . . . . . . . . . 293

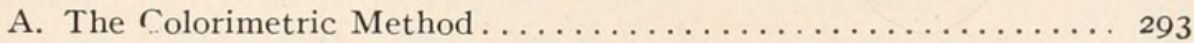

B. The Biometer Method. . . . . . . . . . . . . . . . . . 298

$\checkmark$ I. Influence of Temperature on Head-Frequency . . . . . . . . 300

A. Direct effect of altered temperature............. 300

I. During the Entire Period of Regulation. . . . . . . . . 300

2. During the First Few Hours of Regulation . . . . . . . . . 305

B. An Analysis of Acclimation by the Method of Head-Frequency. . 308

VII. Discussion . . . . . . . . . . . . . . . . . . . . 309

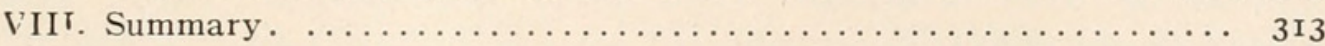

\section{INTRODUCTION.}

It is a familiar fact that within certain limits within which the organism can continue to function normally, metabolic ra:e varies directly with temperature. As far back as 1865 , Sachs (1865) studied the effect of rise in temperature upon a great number of biological phenomena and with a great variety of material, and came to that general conclusion. Very accurate data upon the rate of growth were obtained by Féré (1894) working with hen's eggs; upon rate of activity of protoplasm by Nägeli (I860), Schultze (I863), Hofmeister (I867), and others, and especially by Velten (1876) who made an accurate quantitative determination of the effect of temperature upon the activity of chlorophyll grains in Elodea, Vallisneria and Chara; upon oxygen absorption, by Treviranus (I83I) working on the honeybee; upon carbon dioxide excretion, by Rossbach (1872) in studies on the contraction rate of vacuoles in various protozoa; and 
upon these and other phases of the subject by many other later investigators. The general conclusions on the direct effect of temperature may be summed up in the words of Verworn (I899): "Within certain limits increasing temperature acts to augment vital processes. Up to a certain point excitation increases with increase of temperature. This holds good for very different phenomena and for very different forms of living substance."

But the phenomenon of acclimation to temperature changes, while well known, has not been submitted to extensive analysis. It has been observed of course that in warm springs organisms are found, living at temperatures as high as $85^{\circ} \mathrm{C}$. (Flourens, I846), or even $98^{\circ} \mathrm{C}$. (Ehrenberg, I 859), closely related to species which live in water seldom as high as $40^{\circ} \mathrm{C}$. Acclimation to temperature has also been observed in Euglena, where Schwartz (I884) and Aderhold (I888), working separately, found that Euglena collected in summer are not active below $5^{\circ}$ or $6^{\circ} \mathrm{C}$., in winter at as low as $0^{\circ} \mathrm{C}$. No explanation for this phenomenon is offered and no further experiments have been performed upon this material. But Dallinger (I880) found that flagellates will endure a rise of temperature from $15.6^{\circ} \mathrm{C}$. to $70^{\circ} \mathrm{C}$. if the change is very gradual. And both Schottelius (1867) and Dieudonné (I894) succeeded in causing bacilli which normally produced a fluorescing pigment and trimethylamine at $22^{\circ}$ and not at $35^{\circ}$, to produce these substances at $35^{\circ}$ if kept at that temperature through a sufficient number of generations.

The most complete and elaborate experiments on vertebrates are those of Davenport and Castle (I895) upon Bufo tadpoles, and those of Loeb and Wasteneys (I9I2) upon Fundulus. Davenport and Castle found that Bufo tadpoles kept at $15^{\circ}$ went into heat rigor at $40.3^{\circ} \mathrm{C}$., from which state recovery was possible; but those kept at $25^{\circ} \mathrm{C}$. for 28 days resisted this higher temperature perfectly, going into heat rigor only at $43.5^{\circ}$. If brought back to $I 5^{\circ}$ for $\mathrm{I} 7$ days they lost their resistance to high temperature, but only partially, going into heat rigor now at $4 \mathrm{I} .6^{\circ} \mathrm{C}$. The Fundulus experiments of Loeb and Wasteneys showed similar results. Fish from a temperature of $10^{\circ} \mathrm{C}$. die in less than two hours at $29^{\circ} \mathrm{C}$., and in a few minutes at $35^{\circ} \mathrm{C}$.; but if first exposed to $27^{\circ} \mathrm{C}$. for 40 hours they can live indefinitely at $35^{\circ} \mathrm{C}$., and 
may even endure $39^{\circ}$ if the rise is gradual. This acquired resistance to high temperature persists through four weeks' subsequent exposure to very low temperature. In these two cases an alteration of temperature has evidently produced a persistent effect on the protoplasm.

All the observations and experiments quoted show that organisms have the capacity to acclimate to considerable changes of temperature if these are brought about gradually; but very slight attempts have been made to give an explanation of the physiological significance of the acclimation process. The only noteworthy attempt to analyze the processes involved in acclimation is that of Davenport (I897). In regard to the Confervæ that live in hot springs, he suggests the following: Since it is known that the coagulation point of at least one protein, egg albumin, rises in proportion as it is dried, and since a number of investigators have held that death from high temperature is due to coagulation of proteins, the increased resistance to extreme heat is probably due to loss of water. However, there is some evidence at present that death from high temperature is due rather to accumulation of acids in the tissues (Mayer, 'I 7 ), which throws some doubt upon Davenport's interpretation of acclimation in hot springs. Further, acclimation to extreme cold is, according to Davenport, a loss of irritability. The process of acclimation, then, consists in the modification of protoplasm through excessive heat or cold in such a way that it is not so strongly irritated by these extreme temperatures, and that the coagulation and freezing points are shifted, possibly through loss of water ( 1897, p. 258). This conception of the process of acclimation is inadequate in that it regards protoplasm as a static mass, which alters its condition through successive stages, rather than as a continually changing dynamic system.

The studies reported in this paper were undertaken to determine the effect of temperature changes upon the metabolism of Planaria dorotocephala and to discover if possible a physiological basis for the phenomenon of acclimation to temperature changes.

The work was carried on at the University of Chicago, I9I 5I9I 8, at the suggestion and under the direction of Prof. C. M. 
Child. It is a great pleasure to me to have this opportunity to express my thanks to Professor Child, not only for the stimulus of his ideas and for his valuable suggestions, but for his kindness in placing at my disposal certain unpublished data from his own experiments concerning the effect of temperature on head-frequency and head-form in the regeneration of pieces of Planaria. My warm thanks are due to Dr. L. H. Hyman, of the Department of Zoölogy of the University of Chicago, for her keen and thoughtful criticism, constant encouragement, and constructive advice. I wish further to acknowledge my deep indebtedness to other colleagues and to the friends whose help during these three years has made effort easy.

\section{Material, General Methods and Terminology.}

The material used for these experiments was Planaria dorotocephala, one of the triclad turbellarians, the same species used extensively by Child (' $\mathrm{I}, a, b, c$, etc.) in his earlier studies on the axial metabolic gradient. It is found in the springs that feed into swamps a short distance back from the banks of the Fox River, near Cary, Ill. The material lends itself very well to temperature experiments; for though its natural habitat is in waters of relatively low temperature, the stock lives readily in the laboratory at $\mathrm{I} 7^{\circ} \mathrm{C}$., and can continue to exist to all intents normally in temperatures varying from somewhat over $30^{\circ} \mathrm{C}$. to at least as low as $4^{\circ}$. The temperatures employed all lay well within these limits, between $30^{\circ}$ and $5^{\circ}$. The stock was collected and brought into the laboratory at intervals during the time covered by the experiments, and was fed on liver three times weekly (the frequency which has been found necessary to maintain growth) throughout the period. ${ }^{1}$ With this treatment the stock maintains itself in normal condition.

For the experimental work three general temperatures were employed, approximately $10^{\circ}$ apart; that of the refrigerator ranging between about $8^{\circ}$ and $10^{\circ} \mathrm{C}$., that of the general laboratory, $18^{\circ}$ to $20^{\circ}$; and that of a warm chamber, between $27^{\circ}$ and

1 Dr:ring a part of the tirie high temperature stock was fed mo:e often, as it was found that metabolism is so rapid at raised imperature on tri-weekly feedings that the worms not only may not grow but may even derrease in size. 
$30^{\circ}$ C. For convenience these will be called "low," "medium" and "high," and the exact temperatures given only when this seems significant for the purpose of the experiment. Several other terms used should be explained here. By "living" temperature is meant, not the temperature of the natural environment, but that temperature at which they have been living for a certain experimental period; in acclimation experiments there is an "acclimation temperature." "Regulation temperature" means that temperature to which the worms are subjected during regulation; similarly, "testing temperature" means the temperature at which the metabolic condition of the worms is tested. When two temperatures are given, the first is the living, the second the testing or regulating temperature.

The general methods employed in estimating the effect of temperature upon the metabolism were:

I. Susceptibility.

2. Measurements of $\mathrm{CO}_{2}$ production by

I. Colorimetric method.

2. The biometer.

3. Rate of regulation and head-frequency.

These methods will be described more fully as the experiments are reported.

\section{General Observations.}

Even before any actual experiments are attempted, certain general observations on the effect of temperature upon the worms can be made. Out-of-door stock lives at a temperature of not more than $8-14^{\circ}$. Under these conditions the worms are not very active, rather small but stocky, and of dark color. When brought into the laboratory and kept there under temperature conditions approximately like those out-of-doors they maintain the same general appearance and are very sluggish even in response to light. When kept at ordinary room temperature, however, which during most seasons of the year represents a rise of at least $7-8^{\circ} \mathrm{C}$., the stock becomes more active and loses some of its heavy pigmentation, changes which we have come to associate with more rapid metabolism. Even if well fed the worm shows these changes; and they are much more marked in stock that is put at still higher temperature. At $27-30^{\circ} \mathrm{C}$. 
the metabolic rate is so high that it is difficult to keep stock sufficiently nourished to allow it to increase in size. The worms are restless, and soon become thinner, narrower and much lighter in color. For example, a stock collected November 17, I9I7 and set in the warm chamber January II, I9I8 at average temperature of $27.5^{\circ}$ was fed tri-weekly. The reduction in size was rapid; the worms originally $\mathrm{I} 5^{-1} 8 \mathrm{~mm}$. in length decreased within a period of two weeks to 9-Io mm., and were very much more slender than the worms of the same stock and size in the same temperature under daily feeding. It was further noticed, though no measurements were taken, that this reduction was more rapid, even, than in a parallel starvation stock at lower temperatures-ranging from $14-16^{\circ}$. That these differences in appearance and behavior are directly associated with the metabolic rate needs no further proof. Even the pigment changes cannot be a matter of kind of food but must, it seems, be related to oxidation rate in some such way as the alterations in pigmentation which cause seasonal dimorphism in butterflies (Dorfmeister, I879, Weismann, I895, et al.).

IV. Relation of Susceptibility to Temperature Changes.

The experiments to be reported in this section deal with alterations of metabolic rate in acclimation as tested by the susceptibility method. This method as devised by Child ('I $3 a$ ) consists in subjecting the animals to concentrations of certain agents which will kill them slowly enough to permit one to observe accurately differences in their time of death. Child has sufficiently demonstrated that the time required for death is dependent upon metabolic rate, being shorter the higher the rate. Therefore in my experiments I have used the time required for death as a measure of the effect of various conditions of temperature upon the metabolic rate.

In all the experiments reported here, $\mathrm{KNC}$ was the agent used. The work of earlier physiologists, notably that of Geppert (I889), demonstrated that the action of KNC on vertebrates in some way prevents the tissues from utilizing the oxygen of the blood. Loeb and various other more recent workers have used KNC extensively to inhibit oxidations; and it has been shown 
that cyanides decrease the activity of oxidizing enzymes. Hyman ('I6) has recently shown that in all except very low concentrations cyanides decrease oxygen consumption in the sponge. I am also permitted to mention the results of recent experiments on Planaria dorotocephala not yet published: Dr. Hyman shows that here also cyanides decrease oxygen consumption to a marked degree, and Professor Child has been able to demonstrate a parallel decrease in $\mathrm{CO}_{2}$ production in the same material under the influence of cyanides. This action of $\mathrm{KNC}$ upon oxidation makes it very effective for the purposes of these experiments, since metabolic rates are best measured in terms of oxidative processes. And Child (' $13 a$ ) has presented evidence of the fact that susceptibility to cyanide increases with rise in temperature, so there is good precedent for the use of this agent.

The concentration of KNC found most effective was a I/I,Ooo molecular solution made up with water of the appropriate temperature. In each lot Io worms of as nearly as possible the same size were used. They were put in a Ioo c.c. Erlenmeyer flask, the water drained off and the worms then rinsed in the appropriate cyanide solution (made up fresh each time), after which the flasks were filled and stoppered tightly to prevent loss of KNC by evaporation. The method of recording death rates was that employed by Child ('I5) in which certain arbitrarily defined stages in the course of disintegration were distinguished as follows:

Stage I.-The worm is still intact.

Stage II.-The first signs of disintegration are apparent. These usually appear at the head end but, as we would expect, also very soon in the region of the posterior zooids.

Stage III.-The beginning of disintegration on the margins posterior to the head.

Stage IV.-Margins completely disintegrated.

Stage V.-There is no tissue left with any appearance of life.

From the data thus obtained graphs were plotted by the method that Child has previsouly used ('I5, p. 8I). ${ }^{1}$

1 This methori consists in giving numerical values to the stages of disintegration as follows: Stage II., I; Stage III., 2; Stage IV., 3; Stage V., 4; and using as 


\section{A. Long Time Acclimations.}

In the first series of experiments, stocks of worms were used which had been in the three temperatures for periods of time from three days to three months. The susceptibility of lots of worms from each of these stocks was then tested at a different

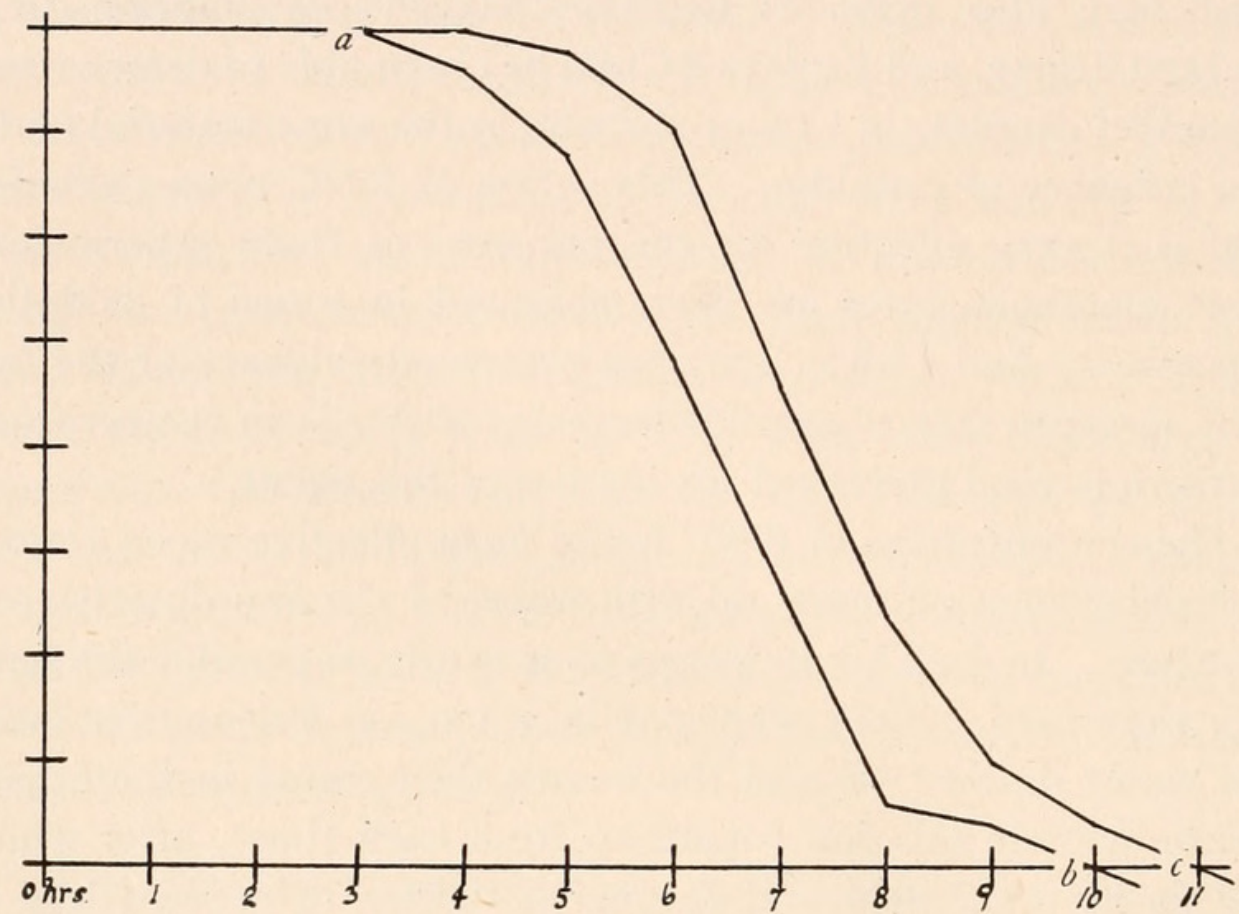

FIG. I:

temperature and compared with that of worms which had been living at that temperature. All possible combinations of temperatures were used. The graphs represented by Figs. I and 2, from worms with one week "acclimation," with temperature ordinates these values multiplied by the number of worms in each stage at each time interval, with the time intervals as abscissæ.

Since ten worms were used in each series, the highest possible numerical total, i. $e$., the largest ordinate, will be 40 , and will be attained when all the worms have reached Stage V., i. e., are dead and disintegrated. The axis of ordinates is therefore divided into 40 spaces, each representing one unit of numerical value, and since the progress of death is most easily represented by descending curves, the ordinates are measured from above downward. Thus, for example, if we have a lot of ten worms which at a given time show the following groupings as regards stages of disintegration:

Stage I. Stage II. Stage III. Stage IV. Stage V

2 worms 2 worms 4 worms 2 worms

The sum of the numerical values will be $2+4+\mathrm{I} 2+8=26$, which is the ordinate for the curve at this time, and is to be measured downward from the zero point (see Fig. I). 
changes in both directions, are typical of the results of such experiments. Fig. I shows the susceptibility of two lots of worms, the experimental lot (medium-high) from a medium living temperature, represented by the curve $a-b$; the control (highhigh) from a high living temperature, represented by the curve $a-c$; the susceptibility of both was tested at high. The position of the curve $a-b$ well to the left of the curve $a-c$ indicates that the worms which have been put suddenly from medium into high temperature to test are more susceptible to cyanide than the worms which have been living at that high temperature for a week previous to testing. Fig. 2 shows the same kind of experi-

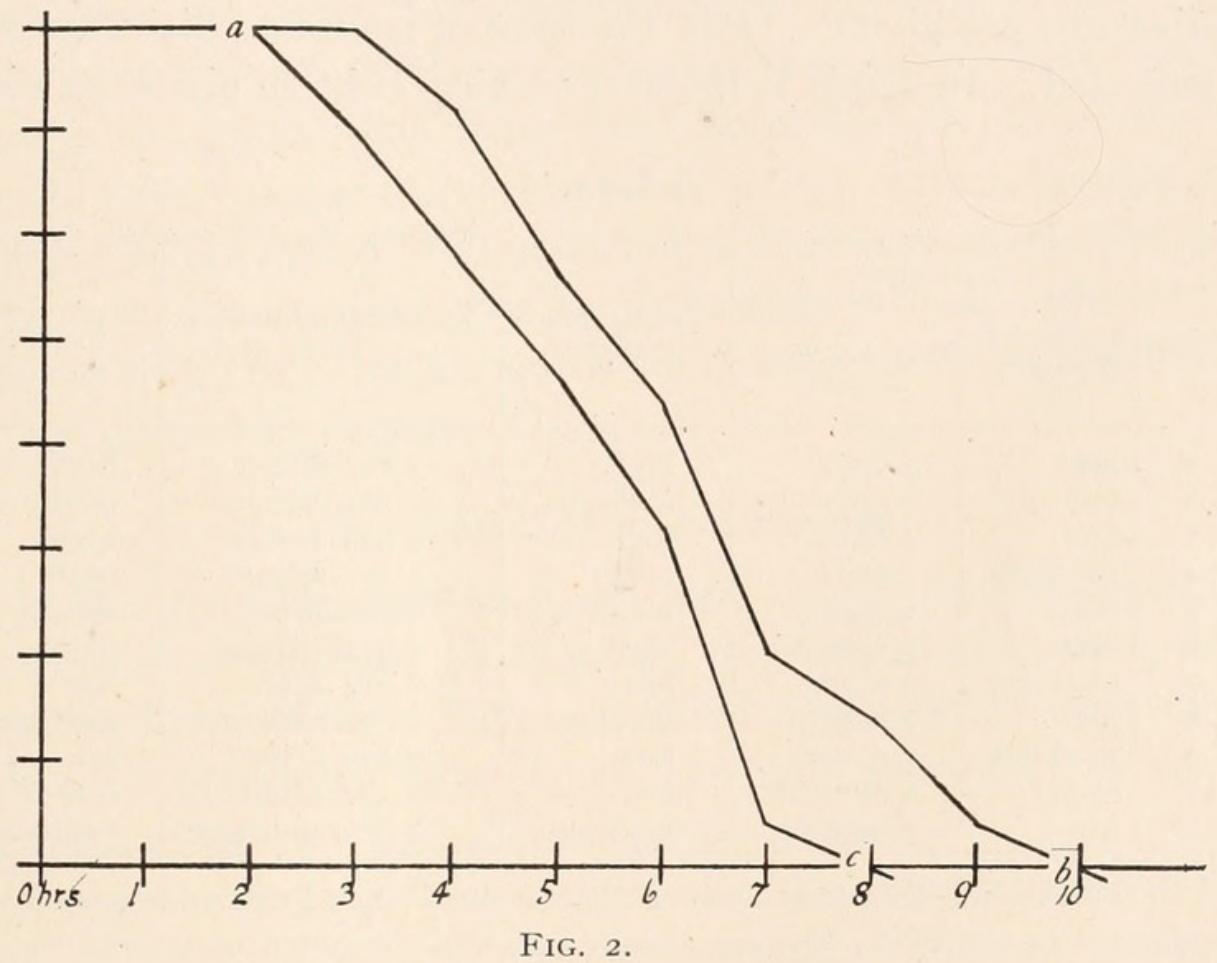

ment with opposite temperature change; here the experimental lot was living at high temperature a week, and its susceptibility, tested at medium temperature, compared with that of a control which had been living at that medium temperature. The curve $a-b$ here represents the experimental (high-medium) lot, the curve $a-c$ the control (medium-medium). The fact that the curve $a-b$ lies well to the right of the curve $a-c$ shows plainly that the worms which have been put into medium temperature to test are less susceptible to cyanide if they have previously been living at high for a week than if they have been in the medium temperature during that length of time. 
It appears from the two graphs, then, that worms whose susceptibility is tested at a higher temperature than that at which they were living for a week are more susceptible than the controls; worms tested at a lower temperature than that at which they had lived a week previously are less susceptible than the controls.

Other data supporting these general conclusions are given below in Table I. Here are given the results of typical experiments differing from those pictured in Figs. I and 2 merely in the length of time that the experimental worms had lived in one temperature before being tested at the other. Some experiments with each direction of temperature change from the living to the testing one are given. Only the time of complete disintegration is recorded. In Table I. the first vertical column gives the series

TABLE I.

\begin{tabular}{|c|c|c|c|c|c|}
\hline \multirow[b]{2}{*}{ Series. } & \multicolumn{2}{|c|}{ Experiment. } & \multirow[b]{2}{*}{$\begin{array}{l}\text { Testing Tem- } \\
\text { perature. }\end{array}$} & \multirow[b]{2}{*}{$\begin{array}{c}\text { Experimental Worms } \\
\text { Died. }\end{array}$} & \multirow[b]{2}{*}{ Controls. } \\
\hline & $\begin{array}{l}\text { Acclimation } \\
\text { Tempera- } \\
\text { ture. }\end{array}$ & $\begin{array}{l}\text { Period of Accli- } \\
\text { mation. }\end{array}$ & & & \\
\hline $\begin{array}{c}\text { I } \\
2 \\
3 \\
4 \\
5 \\
6 \\
7 \\
8 \\
9 \\
\text { IO } \\
\text { I I }\end{array}$ & $\begin{array}{l}\text { low } \\
\text { low } \\
\text { low } \\
\text { medium } \\
\text { high } \\
\text { low- } \\
\text { medium } \\
\text { low- } \\
\text { medium } \\
\text { high } \\
\text { low- }\end{array}$ & $\begin{array}{l}3 \text { days } \\
4 \text { days } \\
4 \text { days } \\
\text { I week } \\
\text { I week } \\
3 \text { weeks } \\
3 \text { weeks } \\
\text { I month } \\
\text { I month } \\
2 \text { months } \\
3 \text { months }\end{array}$ & $\begin{array}{l}\text { high } \\
\text { medium } \\
\text { high } \\
\text { high } \\
\text { medium } \\
\text { high } \\
\text { low } \\
\text { medium } \\
\text { low } \\
\text { low } \\
\text { medium }\end{array}$ & $\begin{array}{l}\text { I hr. before } \\
3 \text { hrs. before } \\
3 \text { hrs. before } \\
\text { I hr. before } \\
6 \text { hrs. after } \\
2 \text { hrs. before } \\
2 \text { hrs. after } \\
2 \text { hrs. before } \\
2 \text { hrs. after } \\
\text { Io hrs. after } \\
2 \text { hrs. + before }\end{array}$ & $\begin{array}{l}\text { high } \\
\text { medium } \\
\text { high } \\
\text { high } \\
\text { medium } \\
\text { high } \\
\text { low } \\
\text { medium } \\
\text { low } \\
\text { low } \\
\text { medium }\end{array}$ \\
\hline
\end{tabular}

* In this case the difference between experimental lot and control is greater than is indicated in the table, because observation was concluded before the controls were completely dead and disintegrated.

numbers; the second column headed "acclimation temperature" gives the temperature the effect of which on a second change of temperature is to be tested. The third column, "acclimaţion period," gives the length of time during which the animals are kept at acclimation temperature. The fourth column, "testing temperature," gives the temperature at which the animals were tested. The fifth column shows whether the experimental lot is more or less susceptible than the control. And the last column shows the temperature at which the control worms were living 
and are tested. For example, in No. I, the experimental worms were kept three days in low temperature; then their susceptibility to KNC was tested at high temperature; and it was found that in general they died an hour earlier than the controls which had been living and were tested at high.

These eleven experiments give results similar to those indicated in the preceding graphs; worms tested immediately after they have been put into a higher temperature than that at which they have been living for a shorter or longer time show greater susceptibility to cyanide than those which have been living indefinitely at the higher temperature; those tested immediately after they have been put into a lower temperature than that at which they have been living for a shorter or longer time show a lower susceptibility to cyanide than those which have been living indefinitely at the lower temperature. In other words, worms brought into a given temperature after a period of exposure to another temperature show a difference in metabolic rate as indicated by susceptibility from the animals which have been living indefinitely at the given temperature.

\section{B. Short Time Acclimation.}

In the preceding section it has been shown that susceptibility to cyanide is modified by exposure to given temperatures for as short a time as three days. Further experiments were undertaken to determine whether or not such modification can be brought about in a still shorter period of time.

A few experiments were performed with worms which had lived but 36 hours at a particular temperature. These experiments presented nothing new and were therefore soon discontinued. Fig. 3 illustrates the general results of such experiments as were made. It is the record of Io worms acclimated to $30^{\circ}$ for 36 hours (curve $a-c$ ), compared in $\mathrm{KNC}$ at $16^{\circ}$ with worms which had been living at $16^{\circ}$ (curve $a-b$ ). This graph shows that worms living at high temperature for 36 hours are less susceptible to cyanide in low temperature than worms which have been living at that low temperature; that is, that even so short a period as 36 hours is long enough to modify the metabolic rate, though not to so marked a degree as longer time intervals. 
A large number of experiments were performed to determine whether a I2 hours' exposure to a given temperature would alter

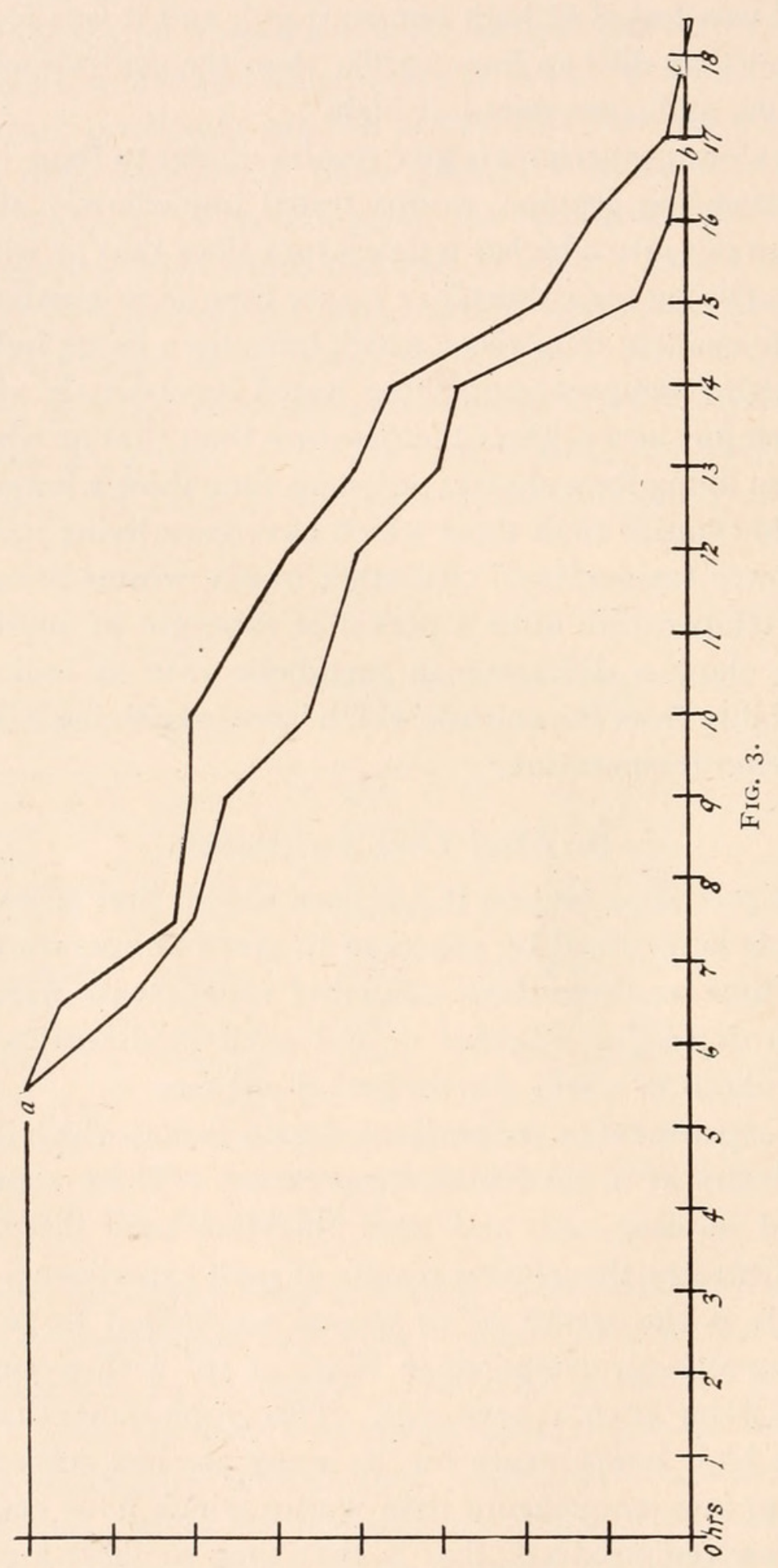

the susceptibility to cyanide. Worms from stocks kept for various lengths of time at one temperature were placed for 
twelve hours in a different temperature; the susceptibility to cyanide was then compared at the second temperature with that of worms from the same stock which had not been exposed to the second temperature until the time of testing. Both lots were tested at the second temperature. If the worms show consistently different death rates it will be proof that time intervals as short as these few hours actually produce persistent modifications in metabolism. The results are more easily tabulated and considered in separate groups according to the direction of the temperature change.

In Table II. the experimental lots are brought into a tempera-

TABLE II.

Lowered Temperature.

Comparative Susceptibility.

\begin{tabular}{|c|c|c|c|c|}
\hline No. & Control Lots. & & Experir & mental Lots. \\
\hline I & high-low & $>$ & high, & I 2 hrs. low \\
\hline 2 & " & $>$ & “ & I 2 hrs. “" \\
\hline 3 & “ & $<$ & “ & I 2 hrs. “" \\
\hline 4 & “ & $=$ & “ & I 2 hrs. "“ \\
\hline 5 & $\because$ & $<$ & ‘ & I 2 hrs. “" \\
\hline 6 & “ & $<$ & “. & I 2 hrs. ". \\
\hline 7 & “ & $<$ & “ & I 2 hrs. “" \\
\hline 8 & ““ & $<$ & “ & I 2 hrs. "“ \\
\hline 9 & “ & $<$ & “ & I 2 hrs. " \\
\hline Io & ““ & $>$ & “. & I 2 hrs. " \\
\hline I I & “ & $<$ & “ & I 2 hrs. "“ \\
\hline I 2 & high-medium & $<$ & “ & I 2 hrs. medium \\
\hline I3 & " & $=$ & “ & I 2 hrs. “ \\
\hline I4 & “ & $>$ & “ & I 2 hrs. \\
\hline I 5 & “ & $<$ & “، & I 2 hrs. " " \\
\hline I6 & medium-low & $<$ & medium, & I 2 hrs. low \\
\hline I 7 & “" & $<$ & “ & I 2 hrs. "، \\
\hline I 8 & “" & $<$ & “" & I 2 hrs. " \\
\hline I9 & “ & $<$ & “ & I 2 hrs. “ \\
\hline 20 & “" & $<$ & “ & I 2 hrs. \\
\hline $2 \mathrm{I}$ & “" & $<$ & “ & I $2 \mathrm{hrs}$. \\
\hline 22 & “، & $<$ & “" & I 2 hrs. " \\
\hline
\end{tabular}

ture below that at which they have been living and remain there I2 hours before determination of their susceptibility is begun. The control lots, on the other hand, are brought into the lower temperature only when the determination of susceptibility begins. The table shows the difference in susceptibility between such 
pairs of lots. In no. I for example, the control lot brought from high to low temperature at the time of susceptibility determination shows a susceptibility greater than that of the experimental lot which has been 12 hours at the low temperature before the susceptibility determination.

Of these twenty-two cases almost 73 per cent. show that I2 hours in a lower temperature than the living one before the addition of cyanide makes the worms more susceptible to cyanide than those which have been subjected to the depressing influence of the cold and of the cyanide simultaneously; in other words, the worms first brought into low temperature then subjected to cyanide die faster than those brought into low temperature and cyanide at the same time. Judging from these data a I2 hours' subjection to a lower temperature produces some degree of adjustment; in most cases the worms have apparently undergone some increase in metabolic rate during the twelve hours at the lower temperature. Just what the nature of this adjustment is had better be considered later when there are more data from which to judge. But that it is not merely a shock effect is evident from a comparison of the effects of acclimation periods of various lengths. In I 2 hours the worms show less acclimation than in 36 hours, and in that period less than in three days, so that evidently the process is not ended in a period shorter than three days, which itself is surely too long a time for shock effect from a change of $10^{\circ}$ to persist. The process then is gradual, covering a considerable period of time, which may range from three days to one week, by which time the acclimation is fairly complete and the new rate established.

The possible sources of error in these experiments account for most of the exceptional results quite readily. The series tested at low temperature all take so long even to begin disintegration that some degree of acclimation undoubtedly occurs in the period before death begins, which would bring the two lots very nearly to the same rate. This might well explain the inconsistency in no. I4, where a relation like the majority held until the last half hour at which time the condition became reversed. The fact that the series were not followed up to complete disintegration may explain the result of nos. 4 and I3. The worms 
of nos. I and 2 belonged to a series which had previously been shifted several times from one temperature to another for very short periods of time; the repeated changes may have been so frequent as to check the effect of the last change. The result of the last of these six exceptions (a little over 27 per cent. of the total number of experiments), no. Io, can only be explained on the ground of possible individual variation.

Twenty-three experiments with temperature changes in the opposite direction were performed. Table III. summarizes the

TABLE III.

Raised Temperature.

Comparative Susceptibility.

\begin{tabular}{|c|c|c|c|c|c|c|}
\hline No. & \multirow{2}{*}{\multicolumn{2}{|c|}{$\begin{array}{c}\text { Control Lots. } \\
\text { low-high }\end{array}$}} & \multicolumn{4}{|c|}{ Experimental Lots. } \\
\hline I & & & $>$ & low, & I $2 \mathrm{hrs}$. & high \\
\hline 2 & “ & “ & $>$ & “" & I 2 hrs. & “ \\
\hline 3 & “ & “ & $=$ & “ & I 2 hrs. & “ \\
\hline 4 & “" & “" & $<$ & “ & I 2 hrs. & “ \\
\hline 5 & “ & “ & $=$ & “ & I 2 hrs. & “ \\
\hline 6 & ““ & “" & $>$ & “ & I $2 \mathrm{hrs}$. & “ \\
\hline 7 & ““ & “" & $=$ & “ & I $2 \mathrm{hrs}$. & “ \\
\hline 8 & “ & “. & $=$ & “. & I 2 hrs. & “ \\
\hline 9 & “ & “ & $>$ & “ & I 2 hrs. & “ \\
\hline IO & “ & “ & $>$ & “ & I 2 hrs. & “ \\
\hline I I & low-n & dium & $>$ & “. & I 2 hrs. & medium \\
\hline I 2 & “ & “ & $=$ & “ & I $2 \mathrm{hrs}$. & “ \\
\hline I 3 & “ & “" & $<$ & “ & I $2 \mathrm{hrs}$. & “ \\
\hline I 4 & “" & “ & $>$ & “ & I 2 hrs. & “ \\
\hline I 5 & “" & “" & $=$ & “ & I 2 hrs. & “" \\
\hline I6 & “" & “" & $>$ & “ & I 2 hrs. & “ \\
\hline I 7 & “ & “ & $>$ & “" & I $2 \mathrm{hrs}$. & “" \\
\hline I 8 & mediu & -high & $<$ & medium, & I 2 hrs. & high \\
\hline I9 & “ & “" & $<$ & “ & I $2 \mathrm{hrs}$. & “ \\
\hline 20 & “ & “" & $<$ & “ & I $2 \mathrm{hrs}$. & “ \\
\hline $2 \mathrm{I}$ & “ & “ & $>$ & “ & I 2 hrs. & “ \\
\hline 22 & “" & “ & $>$ & “ & I 2 hrs. & “ \\
\hline 23 & “" & “" & $>$ & “ & I 2 hrs. & “" \\
\hline
\end{tabular}

results of such experiments. In these series the experimental lots are brought into a temperature higher than that at which they have been living and remain there I 2 hours before determination of susceptibility is begun. The controls, as in Table II. above, are brought into the second temperature (in this case the higher one) only at the time when the determination of suscepti- 
bility begins. The table shows the difference in susceptibility between the two lots. Thus no. I, for example, shows that the susceptibility of a lot ("control") brought from low to high temperature only when the susceptibility determination is begun is greater than that of a lot ("experimental") which has been I2 hours at the high temperature before the susceptibility determination.

We can see from a glance at Table III. that there is much greater variability in the results in the raised temperature series than in the series with lowered temperature. Predicting results on the basis of the previous set of experiments, we would assume that after I 2 hours in a higher temperature than the living one, before subjection to the $\mathrm{KNC}$, the worms would be somewhat less susceptible than similar worms subjected to the new temperature and cyanide simultaneously. In other words, they should have become acclimated to some extent to this second change. Of the 23 series tested to determine this point ten gave the predicted result, six the opposite and seven showed no difference between the experimental and the control animals. Let us examine these to see whether a reasonable explanation for these very variable results can be found. One fact which may throw light on this question is the following: From examination of the graphs, which are not given here for lack of space, it is very evident that of the ten series which gave the result which we predicted from the findings in Table II., one showed a time interval of five hours between the death of the two series, one four hours' difference in time, and four two hours or very little less. The time intervals between complete disintegration of the two lots which showed the opposite type of result (those in which I 2 hours' acclimation did not decrease susceptibility) were mostly shorter; the curves were closer together as a rule. Apparently, then, acclimation to raised temperatures is less rapid than acclimation to lowered ones since susceptibility seems to be much less altered by 12 hours at a temperature higher than that at which the worms have been living than it is by 12 hours at a temperature lower than that at which they have been living. In the case of the highest temperature used, this apparent retardation in the process of acclimation may perhaps be ex- 
plained on the ground that this high temperature is close to the limit at which these animals can live at all after a sudden change; it has been found that they cannot live in a temperature above $30^{\circ}$ unless the temperature is raised very gradually.

The susceptibility method shows then that exposure to a given temperature for even so short a time as $\mathrm{I} 2$ hours produces a change in physiological condition (Tables II., III.). When such a I2-hour period of exposure to a given temperature is followed by exposure to a higher temperature, the susceptibility determined at the higher temperature is higher than that of animals which have been living indefinitely at this higher temperature. The susceptibility determined at a temperature lower than that of the I2 hours' period is lower than the susceptibility of worms which have been living indefinitely at that lower temperature. With increase in the period of exposure to a given temperature this effect shows in general an increase (Table I.).

\section{Carbon Dioxide Production.}

The second method used for demonstrating the differences in metabolic rate at different temperatures consisted in a comparison of the $\mathrm{CO}_{2}$ output of different lots. The measurement of $\mathrm{CO}_{2}$ has long been used by physiologists as one of the best methods available for estimating the change in metabolic rate under experimental conditions. In these experiments carbon dioxide output was measured in two ways: by the colorimeter method and by the biometer.

\section{A. The Colorimetric Method.}

The colorimetric method was an adaptation of that used extensively by Haas in the laboratory of Plant Physiology of Harvard University. It consisted essentially in measuring the comparative $\mathrm{CO}_{2}$ output of two lots of worms in terms of the color change in an indicator solution in which the worms were tested. The following indicators were tried:

$\begin{array}{lll}\text { Alizarin } & \text { Congo red } & \text { Phenolpthalein } \\ \text { Methyl orange } & \text { Benzo-purpurin } & \text { Phenolsulphone-pthalein } \\ \text { Neutral red } & \text { Liquid litmus } & \end{array}$

Of these the turning point of the first three proved to be neither sufficiently close to the $\mathrm{PH}$ of the well water, nor sharply dif- 
ferentiated enough, for the purpose of these experiments. Congo red and benzo-purpurin were not very satisfactory because they were taken up by the slime secreted by the worms so that the color in the solution itself became so varyingly diluted as to make accurate comparison uncertain. Liquid litmus and phenolpthalein were used to some extent; but by far the most satisfactory for the purposes of these experiments was the phenolsulphonepthalein used by Haas (I9I6) which combined all of the desirable qualities for a good indicator-non-toxicity, slowness of the penetration rate, great sensitiveness to very slight increase in $\mathrm{H}$-ion concentration, and a suitable working rangefrom $\mathrm{PH} 8.6$ to $\mathrm{PH}$ 6. The starting point for these experiments was of course the $\mathrm{PH}$ of the well water in which the worms lived in the laboratory-about PH 7.6; but this point is not very significant for the purposes of these experiments as no attempt was made to determine the absolute $\mathrm{PH}$ but rather the comparative changes in $\mathrm{PH}$ in terms of color differences.

In the earlier experiments equal numbers of worms of the same size were compared without weighing. Later, beginning with series XXV., and throughout the rest of the experiments, the worms were weighed and the weights recorded; and an attempt was made to put the excess weight now on one side, now on the other, so as to prevent the weight from being by any possibility the determining factor in the results. The worms were weighed in water at the temperature at which they had been living in each particular case. A small glass container with the water was first quickly balanced, and the worms were placed in this after a moment on filter paper to remove excess water. After weighing they were placed in pyrex tubes of standard volume; these were rinsed and then filled with indicator solution and sealed, with air excluded by paraffined corks, or, better paraffin plugs. The worms were then put into the new temperature away from the direct sunlight and all other strong illumination in order to preclude the possibility of stimulation from those sources. To avoid as far as possible the differences in motor activity resulting from differences in temperature the worms were decapitated, (except in a few cases indicated in the table), shortly before weighing. At any time from ten minutes 
to twenty-four hours after decapitation there is almost complete inactivity in all the different temperatures, and the time between decapitation and experiment was always within these limits. That the animals do not excrete any appreciable amount of any non-volatile acid was shown by the fact that after the color change was produced by the worms the indicator solution could be brought back to the original color by shaking thoroughly with air; and there is no good reason to believe that they excrete any other volatile acid than $\mathrm{CO}_{2}$.

The results obtained by this method are briefly as follows: first, worms brought from a low to a higher temperature show in the higher temperature a higher rate of metabolism as indicated by $\mathrm{CO}_{2}$ production than that of the worms which have lived at the higher temperature; second, so far as the evidence goes worms brought from a higher to a lower temperature show a lower rate of $\mathrm{CO}_{2}$ production than those which have been living at the lower temperature. Table IV. gives the results of 24 experiments in which worms acclimated to low and tested at medium temperature (experimental) are compared with worms which have been living indefinitely and are tested at medium temperature (control).

As can be seen at a glance the majority of these experiments gave very consistent results, extensive and beautiful evidence that worms acclimated to cold showed higher $\mathrm{CO}_{2}$ production in medium temperature than worms acclimated to and tested at the medium temperature. Of the twenty-four experiments performed, seventeen, that is, 83 per cent., gave this result. The possibilities of experimental error here are: Observations over too short a period of time; too great a discrepancy in the weights of the two lots of worms; the inaccuracy of judgment due to the use of an unsatisfactory indicator. Of the four exceptions to the majority rule in this table, three, nos. 2, 6 and $2 \mathrm{I}$, can all be explained on one or the other of these grounds. No. 5 is explicable only as the result of individual variations in rate of $\mathrm{CO}_{2}$ production, which are sometimes considerable.

The other two possible "raised-temperature" series-mediumhigh and low-high-gave results in the main like that of Table IV.; worms acclimated to a lower temperature than the one at 
TABLE IV.

\begin{tabular}{|c|c|c|c|c|c|c|}
\hline \multirow{4}{*}{$\begin{array}{c}\text { No. } \\
\text { I }\end{array}$} & \multirow{3}{*}{$\begin{array}{l}\text { Time Between Beginning } \\
\text { of Experiment and } \\
\text { First Noticeable Color } \\
\text { Difference. } \\
\text { I hr. }\end{array}$} & \multicolumn{5}{|c|}{$\mathrm{CO}_{2}$ Production. } \\
\hline & & Control & ots. & & Experit & ntal Lots \\
\hline & & medium-1 & edium & $>$ & low- & edium \\
\hline & $21 / 2 \mathrm{hrs}$. & “ & “ & $<$ & “ & “ \\
\hline 2 & 5 hrs. & “ & “ & $>$ & “ & “. \\
\hline 3 & 2 hrs. & “ & “ & $=$ & “ & “ \\
\hline & 4 hrs. & “ & “ & $<$ & “ & “ \\
\hline 4 & I $1 / 2 \mathrm{hrs}$. & “ & “ & $<$ & “" & “ \\
\hline 5 & $21 / 2 \mathrm{hrs}$. & “" & ““ & $=$ & “ & “ \\
\hline & $31 / 4 \mathrm{hrs}$. & “ & “ & $>$ & “. & “ \\
\hline 6 & $1 / 2 \mathrm{hr}$. & “ & “. & $>$ & “ & “. \\
\hline 7 & $1 / 2 \mathrm{hr}$. & “" & “ & $>$ & “ & “ \\
\hline & $6 \mathrm{hrs}$. & “ & “ & $<$ & “ & “. \\
\hline 8 & $1 / 2 \mathrm{hr}$. & “ & “ & $>$ & “. & “. \\
\hline & I hr. & “. & “. & $<$ & “ & “ \\
\hline 9 & I hr. & “. & “. & $<$ & “. & “ \\
\hline Io (heads present) & $1 / 2 \mathrm{hr}$. & “ & ““ & $<$ & “. & “. \\
\hline II & $1 / 2 \mathrm{hr}$ & “. & “ & $<$ & “. & “. \\
\hline I2 & 3 hrs. & “. & “. & $<$ & “. & “. \\
\hline I3 (heads present) & $1 / 2 \mathrm{hr}$. & “. & . & $<$ & “ & “، \\
\hline I4 & $1 / 2 \mathrm{hr}$ & “. & “. & $>$ & ، & “. \\
\hline & I $1 / 2 \mathrm{hrs}$. & “. & ، & $=$ & ، & “. \\
\hline & 3 hrs. & “ & “. & $<$ & “. & ، \\
\hline I5 (heads present) & $31 / 2 \mathrm{hrs}$. & “. & “. & $<$ & ، & ، \\
\hline I6 & $31 / 2 \mathrm{hrs}$. & “. & ، & $<$ & “. & ." \\
\hline I 7 & $1 / 2 \mathrm{hr}$ & “. & “. & $<$ & ، & “ \\
\hline I8 & $1 / 2 \mathrm{hr}$. & “. & ، & $<$ & “ & “. \\
\hline I9 (heads present) & $\mathrm{I} 1 / 2 \mathrm{hrs}$. & “. & “. & $<$ & “. & “. \\
\hline 20 & $\mathrm{I} 1 / 2 \mathrm{hrs}$. & “. & “ & $<$ & ، & “ \\
\hline $2 I$ & I hr. & “. & “" & $<$ & ، & ، \\
\hline & 2 hrs. & “. & “. & $>$ & “ & “. \\
\hline 22 & 3 hrs. & “ & “. & $<$ & “. & “. \\
\hline 23 & $3 / 4 \mathrm{hr}$. & “ & “، & $<$ & “ & “. \\
\hline 24 & $3 / 4 \mathrm{hr}$. & “ & “، & $<$ & “ & “، \\
\hline
\end{tabular}

which they were tested produced more $\mathrm{CO}_{2}$ in the same length of time than similar worms acclimated to and tested at the higher temperature. The only exception in this group belonged to a series exceptional in character throughout-with no apparent reason for its non-conformity except individual variations in rate. As a check upon this one series three other series with the same temperature conditions were tried later. The same length of time in the living temperature was allowed, the worms were weighed very carefully and tested with the most delicate indicator; under these conditions the typical result was obtained. 
Few experiments with temperature changes in the opposite direction-acclimation temperature higher than testing temperature - were performed. The least satisfactory of these were the "high-low" vs. "low-low" series. This was because it required so long a time for the worms to show any appreciable $\mathrm{CO}_{2}$ production that a new acclimation may have occurred or at least begun to occur in that time. Series LXVI., I, "highlow" for instance, showed no color change at all even in the controls for more than 24 hours. As the previous experiments had shown even a I2-hour period to permit of some degree of acclimation, it is evident that in the above case we are dealing with something in the nature of a second acclimation. This difficulty could have been obviated by the use of greater numbers of worms; but beyond a few experiments to illustrate this point, no further attempts were made with this temperature combination. The two series "high-medium" vs. "medium-medium" and "medium-low" vs. "low-low" showed in over 60 per cent. of the cases that worms kept at a lower temperature have a higher rate of $\mathrm{CO}_{2}$ production than those which have been suddenly brought into that temperature from a higher one.

Before leaving the subject of the indicator method, a few preliminary attempts to check the short-time acclimation periods may perhaps be mentioned. Though not conclusive on account of their small number, they are at least suggestive. The experimental procedure was as follows: Three lots of worms of as nearly as possible equal weights were taken, two that had been at low temperature, a third, the control, from medium temperature. The heads from all three lots were cut off, but at such times that one of the low temperature lots stood for a number of hoursI2 to 24 -headless before the experiment was begun; immediately after decapitating, this lot was put into medium temperature, so that it had, each time, I 2 to 24 hours in which to adjust to that temperature before its rate of $\mathrm{CO}_{2}$ production began to be measured. This gave for comparison with the control, two lots of the "low-medium" series, one of which was thus tested at once at the time of change of temperature, the other only after it had been given I2-24 hours in which to begin the process of acclimation. From the previous experimental data with short- 
time acclimation we would suppose that the lot given a number of hours' start would have begun a second acclimation to the new temperature and would consequently show a new lower rate, producing less $\mathrm{CO}_{2}$ in the same length of time than the lot which was subjected to change of temperature simultaneously with the beginning of the experiment. As a matter of fact such was the case in a few experiments tried in the way described above, at any rate up to the sixth hour after setting up the experiment, and in one case for as long as twenty-four hours at least. With other combinations of temperature in the same direction, the results were consistent with the above. "Medium-high" and "low-high" lots showed slower $\mathrm{CO}_{2}$ production if given twelve hours' start at the second temperature than if the $\mathrm{CO}_{2}$ production was estimated at once upon change of temperature. Thus even these few tentative experiments give further evidence of an acclimation after only I $2-24$ hours.

\section{B. The Biometer Method.}

The findings as to carbon dioxide production by the colorimetric method are further confirmed by the results of experiments with worms in the biometer, an apparatus devised by Tashiro (I9I4) to show very minute amounts of $\mathrm{CO}_{2}$ by the formation of crystals of barium carbonate on the surface of a drop of the hydrate, and used extensively by him in the study of nerve metabolism and to some extent by him and Child (' $13 b$ ) in experiments on this same form, Planaria dorotocephala. The biometer can be used for comparative estimation of $\mathrm{CO}_{2}$ production in Planaria, but the method is so delicate that the best results are obtained with single individuals except when the worms are very small. With larger numbers the barium carbonate forms too rapidly to permit of accurate comparison,accordingly all the experiments reported here are the results of testing one worm against another. The worms to be tested were decapitated to decrease motor activity, were weighed (in all cases except the first one), then dried for a moment on filter paper and put into the biometer on small cover slips. The method of weighing was the same as that for the colorimetric $\mathrm{CO}_{2}$ determination (see above, p. 293); as often as possible the 
excess weight was put on alternate sides in duplicate experiments, and the position of experimental and control worms in the apparatus was alternated. It should be stated, of course, that only those temperature combinations could be employed in which the testing and the control temperatures were medium since that was the only temperature at which the biometer could be operated. The "low-medium" group gave the same results as the colorimetric experiments of Table IV. above, as far as tried out. But it is from the "high-medium" lot, the one furnishing the less complete records in the colorimetric estimations, that the data below are quoted, since they are characteristic both as regards the majority results and the exceptions. Table $\mathrm{V}$. is a summary of the results of these experiments. Worms which had been living at high temperature were put into the biometer at medium and their $\mathrm{CO}_{2}$ production as determined by $\mathrm{BaCO}_{3}$ precipitation was compared at that temperature with that of worms which had been living at the medium temperature indefinitely.

TABLE V.

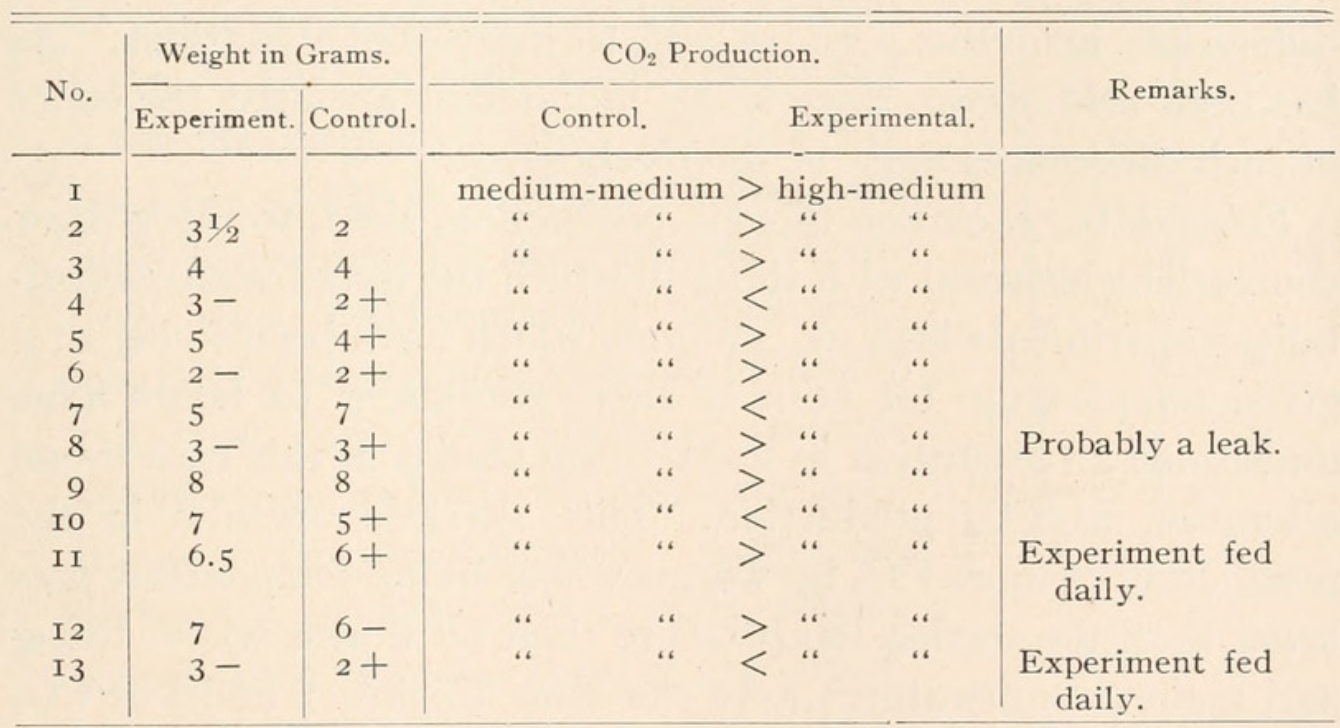

The results in the majority of the experiments harmonize with what we should expect from previous experiments. Of the I 3 experiments here, 8 , that is, nearly 62 per cent., show that animals which have been living at a higher temperature produce $\mathrm{CO}_{2}$ less rapidly, that is, they have a lower metabolic rate when tested out at a lower temperature than do animals which have 
been living at that lower temperature. Of the other four experiments, one, no. 8 (with positive results) has been left out of account, as it seemed probable that there was a leak in the biometer. In considering the exceptions we must bear in mind that small differences in weight may be enough, when dealing with such small amounts of protoplasm, to account for variations. Among the exceptions, three, nos. 4,7 and $\mathrm{I}_{3}$, have the excess weight on the experimental side, but this is not the case with the fourth, no. I2; so weight can hardly be considered the explanation. As earlier experiments had shown that it was hard to maintain high temperature stock at the usual size on tri-weekly feedings, it seemed worth while when the first few cases of nonconformity appeared, to consider whether the irregularity could be found to have a definite relation to the nutritive conditions. But after daily feeding of one stock for a month, the last three experiments, I I, I 2 and I 3 , failed to support any such theory. The excess weight was always on the experimental side yet the results differed in the different experiments, with no direct relation to the feeding. The exceptions here are probably due to slight differences in motor activity and to individual variations. As has been said above, since single individuals are used the effect of such-differences must be relatively great.

From data on carbon dioxide production, then, we may draw conclusions identical with those to which the data from susceptibility experiments lead us. Worms which have been living at a given temperature for even as short periods as I2 hours have undergone an alteration in metabolism shown in this case by an alteration in $\mathrm{CO}_{2}$ production. This alteration results in the production of more $\mathrm{CO}_{2}$ by worms whose living temperature was lower than the testing temperature than by worms whose living and testing temperatures were the same (higher); and less $\mathrm{CO}_{2}$ production by worms whose living temperature was higher than that at which they were tested than by worms whose living and testing temperatures were the same (lower) temperature.

Vi. Influence of Temperature on Head-Frequency.

A. Direct Effect of Altered Temperature.

I. During the Entire Period of Regulation.-Before taking up the question of the effect of acclimation to certain temperatures 
upon the head-frequency of regulating Planaria, we must consider: first, the significance of regulation experiments with this form; second, the factors concerned in head-frequency; and third, the direct effect of temperature on head-frequency.

In a study of regulation, whole worms are cut into certain pieces of equal size and allowed to remain for sufficient length of time to undergo growth and reorganization or redifferentiation. Planaria dorotocephala ordinarily reproduces asexually by fission, and worms above a certain size consist of two or more zooids which are distinguishable physiologically but not morphologically (Child, 'I I $c$ ). Since the head-frequency in the regulation of pieces has been found to vary according to the position of the piece with respect to the boundaries of the different zooids, it is desirable for the sake of uniformity to use pieces from a single zooid. The anterior zooid extending from the head to a short distance behind the mouth is the longest zooid, and most convenient for the purpose. Moreover, since head-frequency varies with length of piece and size of animal (Child,' I $a$, 'I $4 a$, 'I $4 b$, 'I6), pieces of uniform length from animals of approximately the same size must be used. In the experiments reported below, three pieces, representing each one third of the length of the first zooid after removal of the head, are used and are designated $A$,

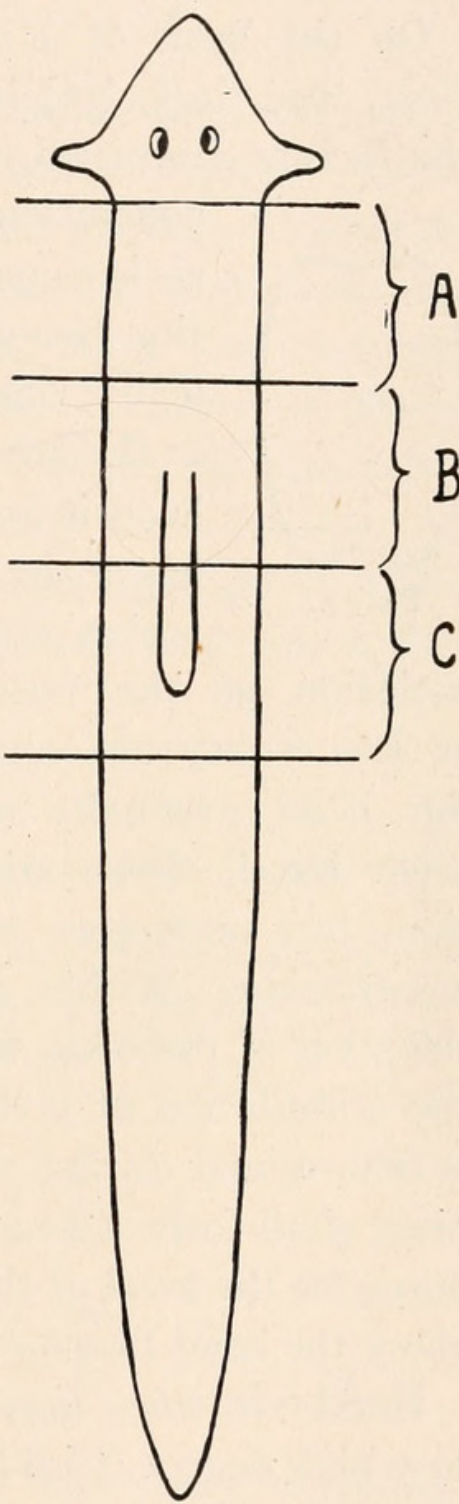

FIG. 4. $B$ and $C$, in order from anterior to posterior (see Fig. 4). In all the experiments unless otherwise stated, the temperatures used were: "low," I0-I2 $2^{\circ}$; "medium" $20^{\circ}$; "high" $29^{\circ}$. During the period of regulation the water was changed frequently to guard against the accumulation of toxic substances. Professor 
Child's morphological classification of the different degrees of cephalic differentiation between normal and headless ('I I $c$ ) is followed in all the tabulations. Worms are classified as normal; teratophthalmic, "teratomorphic, anophthalmic, and headless. In all experiments fifty pieces each were used and the numerical results are given in percentages unless otherwise stated.

On the basis of a wide range of experimental data, Child ('I3c, 'I4 $a$, 'I $4 b$, 'I6) has attempted a physiological analysis of the factors concerned in head-frequency in this species, and his

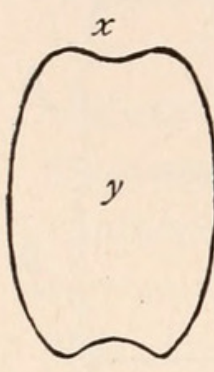

FIG. 5. conclusions are adopted in this paper. His analysis is somewhat as follows: In each piece after section two regions are to be distinguished physiologically, one which can be designated $x$, the region at the anterior end of the piece from which the new head is formed; the other designated as $y$, consisting of the remainder of the piece (see Fig. 5). The region $x$ undergoes more or less complete dedifferentiation as the result of section, its cells attain a more or less embryonic condition, and from this embryonic tissue the head gradually redifferentiates. The region $y$, on the other hand, shows stimulation through the nerves after section, but undergoes relatively little and only gradual dedifferentiation. Within any single individual, the more posterior the level of the body from which the piece is taken the greater the stimulation of $y$ (Child, 'I $4 a$ ). It has been shown that it is determined during this period of stimulation of $y$ whether a piece shall form a head or not (Child, ' $14 b$ ) and that the more posterior the level of the body from which the piece is taken the lower the head-frequency (Child, 'I I $a$, 'I 6 ).

Head-frequency may be experimentally altered and controlled to a high degree (Child, 'I I $e$, 'I6) and the results of experiments along this line together with data noted above concerning the regions $x$ and $y$ have led Child to the conclusion that a new head is formed, not through correlation with and dependence upon the rest of the piece, but so to speak in spite of it. The differentiation of a head is determined by the embryonic cells of $x$, exactly as in the embryo arising from an egg, and the region $y$ can only inhibit head development to a greater or-less degree provided its 
metabolic rate is sufficiently high in relation to that of $x$. All the experimental data agree in pointing to the conclusion that headfrequency increases with increase in rate $x$ in relation to rate $y$, and decreases with the increase of rate $y$ in relation to rate $x$. In other words, we may express head-frequency in the general formula head-frequency $=\frac{\text { rate } x}{\text { rate } y}$.

In order to show the direct effect of temperature on headfrequency, we may compare the head-frequency of pieces which have been living at a given temperature and undergo regulation at another temperature higher or lower than the first, with the head-frequency of pieces which have been living and undergo regulation at the first temperature. ${ }^{1}$ Table VI. shows the effect on head-frequency of a rise from low to medium temperature, Table VII. the effect of a fall in temperature from medium to low, and Table VIII. the effect of a rise from medium to high. In each lot, $A, B$ and $C$ consist of 50 pieces, and the headfrequencies are given in percentages.

TABLE VI.

Worms Which Have Been Living for Six Weeks at Low Temperature, Regulating at Medium.

\begin{tabular}{|c|c|c|c|c|c|c|c|c|c|}
\hline Series. & Living Temp. & Reg. Temp. & ֻّّ & हू் & 递总 & 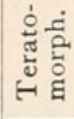 & 这 & 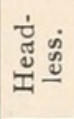 & 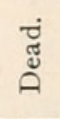 \\
\hline $\begin{array}{c}\text { 4I9 A. } \\
\text { I. }\end{array}$ & Low & Medium & $\begin{array}{l}\text { A } \\
\text { B } \\
\text { C }\end{array}$ & $\begin{array}{l}86 \\
56 \\
\text { I0 }\end{array}$ & $\begin{array}{l}\text { I } 4 \\
42 \\
62\end{array}$ & $\begin{array}{r}2 \\
14\end{array}$ & 8 & 4 & 2 \\
\hline 2. (control) & Low & Low & $\begin{array}{l}\text { A } \\
\text { B } \\
\text { C }\end{array}$ & 24 & $\begin{array}{l}76 \\
40 \\
\mathrm{I} 4\end{array}$ & $\begin{array}{l}6 \\
2\end{array}$ & $\begin{array}{l}5^{2} \\
3{ }^{\circ}\end{array}$ & $\begin{array}{r}2 \\
50\end{array}$ & 4 \\
\hline
\end{tabular}

In Table VI., for example, where the first series of pieces have been living at low and undergo regulation at medium temperature, while the second series have been living and undergo regulation at low, the rise in temperature produces a very great increase in head-frequency. In the $A$ pieces, with 24 per cent.

${ }_{1}$ These tables are made up froin unpublished records of Professor Child which he has had the great kindness to put at my disposal. Practically all my own data along this line were rendered worthless by the chlorination of the city water. 
TABLE VII.

Worms Which have Been Living for a Number of Months in the Laboratory at Medium Temperature, Regulating at Low.

\begin{tabular}{|c|c|c|c|c|c|c|c|c|c|}
\hline Series. & Living Temp. & Reg. Temp. & ن⿺辶ِ & $\begin{array}{l}\text { ह் } \\
\text { ż }\end{array}$ & & 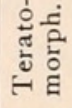 & di & 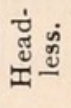 & 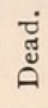 \\
\hline \multicolumn{9}{|l|}{435} & 6 \\
\hline & & & $\begin{array}{l}\text { B } \\
\text { C }\end{array}$ & 2 & $\begin{array}{r}56 \\
2\end{array}$ & $\begin{array}{l}4 \\
6\end{array}$ & $\begin{array}{l}28 \\
28\end{array}$ & $\begin{array}{l}\text { IO } \\
40\end{array}$ & 24 \\
\hline 2. (control) & Medium & Medium & $\begin{array}{l}\text { A } \\
\text { B } \\
\text { C }\end{array}$ & 78 & $\begin{array}{l}22 \\
74 \\
20\end{array}$ & $\begin{array}{l}6 \\
6\end{array}$ & $\begin{array}{l}\text { I } 8 \\
24\end{array}$ & $\begin{array}{r}2 \\
50\end{array}$ & \\
\hline
\end{tabular}

normal and 76 per cent. teratophthalmic in the control, the rise in temperature for regulation alters this head-frequency to 86 per cent. normal and 14 per cent. teratophthalmic. In the $B$ pieces the control shows no normals, 40 per cent. teratophthalmic, and 52 per cent. anophthalmic with 8 per cent. teratomorphic and headless together, while the rise in temperature alters this head-frequency to 56 per cent. normal, 42 per cent. teratophthalmic and only 2 per cent. of the lower types. In $C$ pieces a similar increase in head-frequency results from a rise in temperature. Table VII. shows a great decrease in head-frequency

\section{TABLE VIII.}

Worms Which Have Been Living for Almost Two Months in the Laboratory at Medium Temperature, Regulating at High.

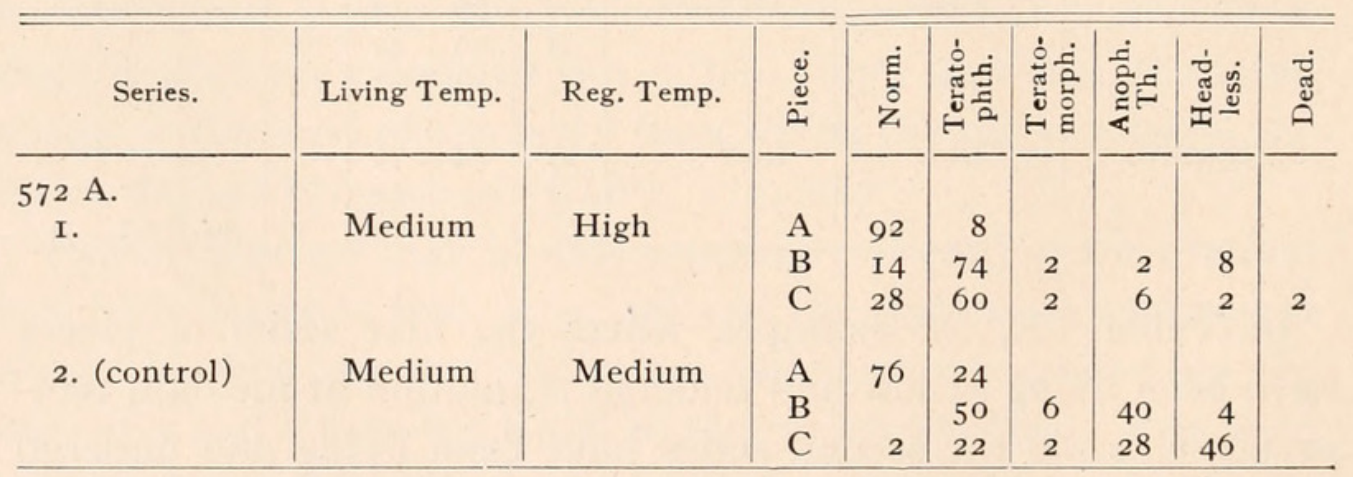

as the result of regulation at a lower temperature than the living temperature. And Table VIII. shows an increase in headfrequency as the result of regulation in a temperature higher than the living temperature. 
Let us consider briefly the significance of the data in the light of the interpretation of head-frequency suggested above. It will be seen that at a lowered temperature the head frequency throughout is lower than it would have been at the original temperature; at raised temperature it is higher than it would have been at the original temperature." Alteration of temperature then must affect $x$ more than $y$; for if this were not the case we should expect head-frequency to remain unaltered. Apparently, then, the $x$ cells are more susceptible to the direct effect of temperature changes than those of $y$.

This greater susceptibility of the $x$ cells to temperature change is also indicated by the fact that at $4^{\circ} \mathrm{C}$. the $x$ region is incapable in almost 100 per cent. of the cases of giving rise to any head at all; although if the changes in temperature have not been too rapid the pieces may still remain alive at this temperature. Pieces kept for some five months at this temperature remained headless; but when brought into medium temperature gave rise to a high percentage of heads, many of which were normal. At this extremely low temperature life was maintained, but little or no growth of the physiologically younger cells of $x$ occurred.

2. During the First Few Hours of Regulation.-Another series of experiments was conducted to see what would be the effect of temperatures applied for shorter periods of time than the whole time of regulation. These experiments were in a sense preliminary to acclimation experiments proper. They lie in intermediate position between those testing the direct effect of temperature during regulation and those testing the power of adjustment of the organism to temporary changes, and the extent to which such changes permanently alter the metabolic rate.

It has been found experimentally (Child, 'I $4 b$ ) that whether a head shall be formed or not is determined within $3^{-6}$ hours after sectioning. ${ }^{1}$ These experiments were repeated by me with like results (see Table IX. below).

We know that long pieces from standardized stock, such as $a-x$ (Fig. 6), produce practically Ioo per cent. normal heads. We also know that pieces such as $a-b$ (Fig. 6) whose anterior

\footnotetext{
${ }^{1}$ Similar data have been worked out for Lumbriculus inconstans by Hyman (' $16 a$ !
} 
ends are as nearly as possible at the same body level as the anterior ends of the long pieces give practically ioo per cent. headless forms. Moreover, we find that when a piece such as

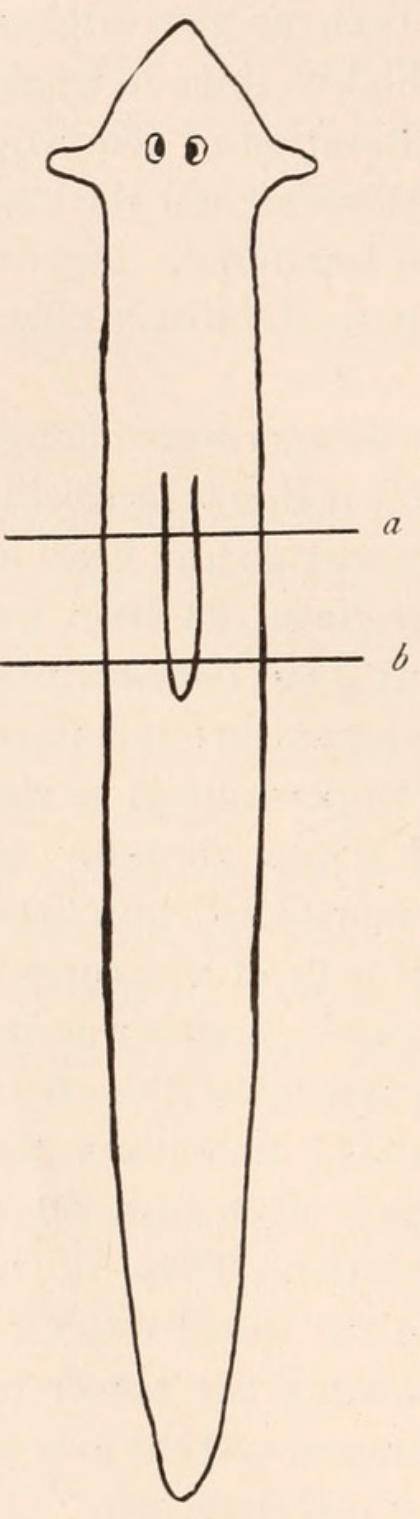

$x$

FIG: 6 . $a-b$ has remained for a few hours as the anterior portion of the long piece $a-x$ and is then isolated, it usually gives rise to a head. It is evident that at the anterior end of the piece conditions determining head formation have been so fixedly established during these few hours that they are not essentially altered by the later isolation of the short piece, although when the short piece is isolated at once head formation is inhibited.

The experimental procedure is as follows: A lot (A) of 25 or 50 long pieces $(a-x$, Fig. 6) are cut and allowed to regulate, and head-frequency noted. A second lot (B), short pieces ( $a-b$, Fig. $6)$, are likewise cut and allowed to regulate. These serve as controls. Several hundred long pieces ( $a-x$, Fig. 6) are now cut, and from the anterior regions of these, lots (C, D, E, etc.) of short pieces ( $a-b$, Fig. 6) are cut at different intervals following the first section. In this way the head forming region is left for a certain length of time as the anterior end of the long piece before it becomes the anterior end of the short piece. Table IX. gives the results of such a series of experiments.

Evidently the process of head determination then begins almost immediately after section and the conditions existing in the piece during the first few hours after section must constitute the most important factor determining the character of the result.

The controls $A$ give Ioo per cent. heads, whereas the controls 
TABLE IX.

\begin{tabular}{|c|c|c|c|}
\hline Lot. & $\begin{array}{c}\text { Length of Time Between Two Cuts, at } a \\
\text { and at } b .\end{array}$ & $\begin{array}{l}\text { Per Cent. } \\
\text { Heads. }\end{array}$ & $\begin{array}{l}\text { Per Cent. } \\
\text { Headless. }\end{array}$ \\
\hline $\begin{array}{r}\text { XXIV. A } \\
\text { B } \\
\text { C } \\
\text { D } \\
\text { E } \\
\text { F }\end{array}$ & 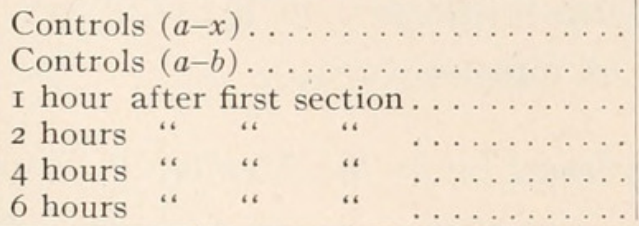 & $\begin{array}{r}100 \\
8 \\
40 \\
64 \\
88 \\
92\end{array}$ & $\begin{array}{r}92 \\
60 \\
36 \\
\mathrm{I} 2 \\
8\end{array}$ \\
\hline
\end{tabular}

$B$ give only 8 per cent. heads, and in the lots $\mathrm{C}, \mathrm{D}, \mathrm{E}, \mathrm{F}$, cut from the anterior ends of the long pieces at different intervals, it is evident that head-frequency increases with the length of the interval and that 6 hours' connection with the long piece is a sufficient interval to form a head in 92 per cent. of the pieces.

The demonstration of the occurrence of head determination within so short a period of time furnished good ground for the belief that temperature, acting through similar periods of time, would be able to produce an effect upon head-frequency. A few experiments along this line were undertaken. Worms from medium temperature were cut and immediately put for three hours into low temperature, after which they were left to regulate at medium temperature, and their head-frequency compared with that of a medium temperature series not subjected to low temperature. The results of such a series of 25 worms are given below in Table $\mathrm{X}$. The death rate is somewhat high but the differences in head-frequency indicate some effect of the temperature change. Although these differences are slight, several repetitions of the experiments showed the same results, which are therefore to be considered typical.

TABLE X.

\begin{tabular}{|c|c|c|c|c|c|}
\hline Lot. & $\begin{array}{l}\text { Temp. for } 3 \text { Hrs. } \\
\text { After Cutting. }\end{array}$ & Reg. Temp. & $\begin{array}{l}\text { Heads, } \\
\text { Per Cent. }\end{array}$ & $\begin{array}{l}\text { Headless, } \\
\text { Per Cent. }\end{array}$ & $\begin{array}{l}\text { Dead, } \\
\text { Per Cent. }\end{array}$ \\
\hline $\begin{aligned} & \text { XIV. } 5^{1} \\
& \mathrm{~A} \\
& \mathrm{~B} \\
& \mathrm{C}\end{aligned}$ & Medium & Medium & $\begin{array}{l}98 \\
74 \\
48\end{array}$ & $\begin{array}{r}2 \\
18 \\
52\end{array}$ & 8 \\
\hline $\begin{aligned} \text { XIV. I } \\
\mathrm{A} \\
\mathrm{B} \\
\mathrm{C}\end{aligned}$ & Low & Medium & $\begin{array}{l}88 \\
60 \\
40\end{array}$ & $\begin{array}{r}8 \\
34 \\
42\end{array}$ & $\begin{array}{r}4 \\
6 \\
\mathrm{I} 2\end{array}$ \\
\hline
\end{tabular}


From the above table it will be seen that the effect of lowering temperature during the beginning of the period of regulation is of the same sort as the effect of a temperature continued during the whole period. Head-frequency is lowered throughout the series by the lowering of temperature.

B. The Analysis of Acclimation by the Method of Head-Frequency.

In the experiments of the preceding section, worms were taken from temperatures at which they had been living so long that there could be no doubt that acclimation is practically completed. In this section worms were used which had been living at a given temperature for shorter periods of time before putting into a new temperature to regulate. In this way an attempt was made to determine for how long a period worms must live in one temperature before acclimation to that temperature occurs to such a degree that it will affect the head-frequency at a new temperature.

The method consisted in keeping worms at a certain temperature for various lengths of time, from three days to three weeks. Then cutting $\mathrm{A}, \mathrm{B}$ and $\mathrm{C}$ pieces for regulation at another temperature and comparing their head-frequency with that of pieces from animals living at the second temperature. A difference in head-frequency between the two lots will indicate that the first temperature has had some effect on the reaction to the second.

The following table gives a resumé of the results of such experiments with acclimation periods of from 3 days to 3 weeks.

Taking the first series as an illustration, the animals were kept at low temperature for three days and the $A, B, C$ pieces when cut were placed in medium temperature for regulation. The head-frequency of this series was then compared with that of a control series which had been living and underwent regulation at the regulation (in this case medium) temperature. In this first series the head-frequency of the worms kept at low for three days before the pieces were cut shows in the $A$ pieces a decrease, in the $B$ and $C$ pieces an increase in head-frequency as compared with the control. The data for the other series are recorded in the same way.

The table shows that the effect on head-frequency for shorter 
TABle XI.

\begin{tabular}{|c|c|c|c|c|c|}
\hline \multirow{2}{*}{ Series. } & \multirow{2}{*}{$\begin{array}{l}\text { Length and Temperature } \\
\text { of Acclimation Period. }\end{array}$} & \multirow{2}{*}{$\begin{array}{c}\text { Regulation } \\
\text { Tempera- } \\
\text { ture. }\end{array}$} & \multicolumn{3}{|c|}{$\begin{array}{l}\text { Head-frequency Compared with that of Worms } \\
\text { Kept and Regulating at Regulation Temperature }\end{array}$} \\
\hline & & & A. & B. & C. \\
\hline I & low, 3 days & medium & decrease & increase & increase \\
\hline 2 & low, 3 days & “ & & & “ \\
\hline 3 & low, 3 days & “ & “. & “. & “ \\
\hline 4 & high, 3 days & “ & “ & decrease & decrease \\
\hline 5 & low, 3 days & & increase & increase & increase \\
\hline 6 & medium, 3 days & high & decrease & decrease & decrease \\
\hline 7 & low, 4 days & medium & increase & increase & increase \\
\hline 8 & medium, 4 days & high & decrease & “. & “" \\
\hline 9 & low, 4 days & & & “ & decrease \\
\hline Io & medium, I week & low & increase & $=$ & . \\
\hline I I & medium, I week & high & & increase & “” \\
\hline I 2 & low, I week & medium & decrease & & - \\
\hline I3 & medium, 3 weeks & low & & decrease & decrease \\
\hline I 4 & low, 3 weeks & medium & increase & increase & increase \\
\hline I 5 & low, 3 weeks & high & & & \\
\hline 16 & medium, 3 weeks & high & increase & “" & “. \\
\hline I 7 & low, 3 weeks & high & "، & “ & “ \\
\hline 18 & low, 3 weeks & medium & “. & “. & “. \\
\hline I9 & high, 3 weeks & medium & decrease & decrease & - \\
\hline 20 & low, 3 weeks & medium & increase & increase & increase \\
\hline
\end{tabular}

periods up to one week is not entirely uniform; while with three weeks at the acclimation temperature, there is uniformity, headfrequency being higher than that of the control when the regulation temperature is higher than that of acclimation and vice versa. As might be expected, the head-frequency method of demonstrating the effect of acclimation is not as delicate as the other methods employed, and consequently longer periods of acclimation are required to give consistent and uniform results. Since the physiological methods have shown that at least some degree of acclimation to temperature occurs within a few hours (see pp. 307-8 above), it is evident that when pieces are brought into the new temperature for regulation the effect of any temperature to which they have been previously subjected will be more or less compensated by the beginning of acclimation to the new temperature even before head-frequency is determined. Consequently, this method can be expected to show only the larger effects resulting from longer periods of acclimation.

VII. Discussion.

The experimental data on susceptibility, on $\mathrm{CO}_{2}$ production as estimated both colorimetrically and by the biometer, and on 
head-frequency in regulation all agree in indicating that when individuals of Planaria dorotocephala are subjected to changes in temperature which are not too extreme, two sorts of change in metabolic condition are distinguishable. The first of these is the change in oxidation rate which is the direct effect of the change in temperature, and is either an increase or a decrease in rate according as the change consists in a rise or a fall in temperature. The second is a gradual process of acclimation extending over days or weeks and apparently gradually approaching a limit. This process involves an alteration opposite in direction to the first, consisting in a gradual decrease in oxidation rate if the change is from a lower to a higher temperature, an increase if the change is from a higher to a lower temperature.

That this alteration in rate is a real acclimation and not merely a recovery from the shock of a change in temperature is indicated first by the fact that extreme changes are not necessary to bring it about; second, by the fact that it occurs when the temperature is raised the same number of degrees gradually as well as when it is raised abruptly, and third, that it only begins to be appreciable after twelve hours or more and may extend over a period of weeks. Recovery from any shock that might conceivably result from a change of $10^{\circ}$ in temperature in an animal like Planaria might be expected to occur within a much shorter period of time than this acclimation process.

The acclimatory change in rate of oxidation, a decrease following rise, an increase following fall in temperature, represents the working of a regulatory mechanism which shows some resemblances in its results to the mechanism of temperature regulation in the warm-blooded animals. There, too, a rise in temperature brings about a decrease in rate of oxidation, and a fall, an increase in rate. It seems probable that a regulatory mechanism working in much the same way as that of Planaria will be found in other cold-blooded animals, and that such a general mechanism of acclimation to temperature in cold-blooded animals is the basis from which the temperature-regulating mechanism of warmblooded animals is developed and elaborated.

The main differences between a general mechanism of acclimation to temperature such as that of Planaria and a temperature- 
regulating mechanism such as that of warm-blooded animals seem to be that the former acts relatively slowly and only partially compensates the direct effect of temperature change; whereas the temperature-regulating mechanism acts very rapidly and maintains a uniform body temperature over a wide range of external temperature change.

Since the establishment of the fact that the usual temperature coefficient of velocity of chemical reaction for $\mathrm{IO}^{\circ} \mathrm{C}$. within ordinary temperature range is between 2 and 3 , and that the temperature-coefficients of many physical processes are of very different orders of magnitude, the temperature coefficients of various physiological processes have been determined on the assumption that such coefficients will show whether chemical or physical processes are primarily concerned. Snyder ('o8) found that the velocities of nerve impulses follow van't Hoff's law for chemical reactions. Van Slyke and Cullen ('I4) observed that the reaction rate of the enzyme urease is nearly doubled by every $\mathrm{Io}^{\circ}$ rise in temperature between $10^{\circ}$ and $40^{\circ}$, the average temperature coefficient being I.9I within this range. Loeb and Wasteneys ('II) investigated the temperature coefficient for the rate of oxidation in newly fertilized Arbacia eggs and found it to be remarkably constant, about 2. And Lillie and Knowlton ('97) showed the temperature coefficient for the development of the egg of the frog to be of the same nature as that for chemical reactions. A great number of other similar cases might be quoted. Yet with the increase in knowledge along this line it has become increasingly evident that caution is necessary in generalizing from such data; for not only are some of the chemical and physical temperature coefficients almost identical, but as Bayliss ('I5, p. 43) and others have pointed out, the physiological processes are processes occurring in heterogenous systems in which even when a chemical reaction occurs, other processes must also be concerned; and the velocity of the whole will be conditioned by that process the rate of which is lowest under the given conditions.

The experiments on temperature acclimation in Planaria show that in addition to the direct effect of temperature on the velocity of cer ain physiological processes, there is a secondary effect 
occurring gradually and proceeding in the opposite direction from the first; that is, after a change in temperature, the velocity of physiological processes must undergo a gradual progressive change apparently approaching a limit in a constant temperature. Such a change manifestly cannot be an effect of temperature on the velocity of chemical reaction, but must result from an action of the altered velocity and other temperature effects associated with it upon the constitution or condition of the heterogenous protoplasmic system. These changes in the system in turn condition further gradual alterations in the velocity of reactions even though the temperature remains constant.

The effect of temperature upon head-frequency suggests that the processes in the region $x$ (Fig. 5), the cells of which undergo extreme dedifferentiation and rapid growth and are directly concerned in head-formation, are altered to a greater degree by change in temperature than those in the region $y$. Regulation at a higher temperature than that at which the animal has been living increases, and regulation at a lower temperature decreases head-frequency. Moreover, acclimation to a given temperature alters the reaction, as indicated by head-frequency, to another temperature (Table XI.). This table also shows that animals acclimated to a high temperature show a lower head-frequency, and animals acclimated to a low temperature, a higher head-frequency, than those brought into that temperature at the beginning of regulation. These effects are in general opposite in direction to the direct effects of temperature change. If headfrequency $=\frac{\text { rate } x}{\text { rate } y}($ pp. $302-3)$, as various lines of experimental evidence indicate, it is evident; first, that changes in temperature must directly alter rate $x$ more than rate $y$; and second, that acclimation to a given temperature preceding regulation produces its effect by altering the metabolic level at which the regulatory processes in the cells of $x$ begin.

These conclusions are in complete agreement with other data on acclimation to temperature and to other conditions in Planaria. In general, direct susceptibility to change in conditions and also capacity for acclimation to conditions which are not too extreme vary with rate of oxidation (Child, 'I $3 a$, 'I $3 c$, 
I4a, I4c, 'I6). A physiologically young animal shows a higher susceptibility to change in conditions as indicated by direct effect, and also is able to become more rapidly and completely acclimated to changes which are not too extreme. The cells of $x$ undergo extreme dedifferentiation after section and become essentially embryonic cells before giving rise to a head. In an isolated piece then they very soon become physiologically younger than the cells of $y$, and the higher susceptibility of $x$ to temperature changes as well as the effects of acclimation are unquestionably associated with this change in physiological condition and increase in metabolic activity.

In short, the data on head-frequency not only indicate direct and acclimatory effects of temperature of the same sort as those indicated by susceptibility to cyanide and $\mathrm{CO}_{2}$ production, but they also indicate that these temperature effects are not the same for cells or tissues in different physiological condition. Here again the difficulty of drawing definite conclusions as to existence of a temperature coefficient of physiological processes is evident, from the fact that the rate of increase in the velocity of reaction may vary with the physiological condition of the cells or tissues concerned.

\section{Summary.}

I. The susceptibility of Planaria dorotocephala to toxic concentrations of KNC increases with rise and decreases with fall in temperature.

2. When animals which have been living at one temperature are subjected to another a gradual change in susceptibility to $\mathrm{KNC}$ in the new temperature occurs. In animals brought from a lower to a higher temperature the susceptibility undergoes gradual decrease at the higher temperature, and in animals brought from a higher to a lower temperature the susceptibility undergoes a gradual increase at the lower temperature. These secondary changes in susceptibility are distinguishable after twelve hours' subjection to a new temperature, but extend over days or weeks, apparently gradually approaching a limit. These changes occurring in a temperature higher or lower than that at which the animals have previously been living represent a process of acclimation. 
3. Estimations of $\mathrm{CO}_{2}$ production by a colorimetric method and by the Tashiro biometer give essentially the same results as the susceptibility method. The increase in $\mathrm{CO}_{2}$ production which occurs when animals are brought from a lower to a higher temperature is followed by a gradual decrease at the higher temperature; and the decrease in $\mathrm{CO}_{2}$ production which occurs when animals are brought from a higher temperature is followed by a gradual increase in $\mathrm{CO}_{2}$ production at the lower temperature.

4. Experiments on the effect of temperature on head-frequency in the regulation of pieces give results similar to those on susceptibility and on $\mathrm{CO}_{2}$ production. Rise in temperature increases, fall in temperature decreases, head-frequency, but acclimation determines changes in head-frequency in opposite directions from those directly determined by change of temperature. Animals which have become acclimated to a high temperature show a lower head-frequency in regulation than those brought in to that temperature at the beginning of regulation; and animals acclimated to low temperature show a higher head-frequency than those brought into that temperature at the beginning of regulation.

5. All the experimental data agree in indicating that, within the temperature range of the experiments, acclimation to a change in temperature upward consists in changes which manifest themselves physiologically as a gradual decrease in rate of metabolism or oxidation; and acclimation to a change in temperature downward consists in changes which manifest themselves physiologically as a gradual increase in rate of metabolism or oxidation.

6. The working of the regulating mechanism concerned in acclimation to temperature resembles as regards its action on metabolism the temperature-regulating mechanism of warmblooded animals, but is very much slower and less effective as a compensatory mechanism than the latter. It may perhaps be regarded as representing the general basis from which a temperature-regulating mechanism has developed. 
Aderhold, R.

\section{BIBLIOGRAPHY.}

'88 Beitrag zur Kenntniss richtender Kräfte bei der Bewegung niederer Organismen. Jena Zeitschr., XXII., pp. 310-342.

Bayliss, W. M.

'I5 Principles of General Physiology. Longmans, Green \& Co., London.

Child, C. M.

'I I S Studies on the Dynamics of Morphogenesis and Inheritance in Experimental Reproduction in Planaria dorotocephala. I., The axial gradient in Planaria dorotocephala as a limiting factor in regulation. Jour. Exp. Zoöl., X., 3 .

'Irb Studies in the Dynamics, etc. II., Physiological dominance of anterior over posterior regions in the regulation of Planaria dorotocephala. Jour. Exp. Zoöl., XI., 3.

'IIc Studies in the Dynamics, etc. III., The formation of new zooids in Planaria and other forms. Jour. Exp. Zoöl., XI., 3.

'IId A Study of Senescence and Rejuvenescence, based on Experiments with Planaria dorotocephala. Arch. f. Entw.-mech., XXXI., p. 537.

'ire Experimental Control of Morphogenesis in the Regulation of Planaria. Biol. Bull., XX., No. 6.

'rза Studies, etc. V., The relation between resistance to depressing agents and rate of metabolism in Planaria dorotocephala and its value as a method of investigation. Jour. Exp. Zoöl., XIV., p. I53.

'rзb Certain Dynamic Factors in Experimental Reproduction and their Significance for the Problems of Reproduction and Development. Arch. f. Entw.-mech., XXXV., p. 598.

'r3c Studies, etc. VI., The Nature of the Axial Gradients in Planaria and their Relation to Antero-posterior Dominance, Polarity and Symmetry. Arch. f. Entw.-mech., XXXVII., p. Io8.

'r4a Studies, etc. VII., The stimulation of pieces by section in Planaria dorotocephala. Jour. Exp. Zoöl., I6, p. 4I3.

'I4b Studies, etc. VIII., Dynamic Factors in Head Determination in Planaria. Jour. Exp. Zoöl., XVII., p. 6I.

'I4c Starvation, Rejuvenescence and Acclimation in Planaria dorotocephala. Arch. Ent. Mech., XXXVIII.

'I5 Senescence and Rejuvenescence. University of Chicago Press.

'r6 Studies, etc. IX., The Control of Head Form and Head-Frequency in Planaria by means of Potassium Cyanide. Jour. Exp. Zool., XXI., p. Io I.

\section{Dallinger, W. H.}

'8o On a Series of Experiments made to Determine the Thermal Death Pyint of Known Monad Germs when the Heat is endured in a Fluid. Jour. Roy. Micr. Soc., III., pp. I-I6.

\section{Davenport, C. B.}

'97 Experimental Morphology. MacMillan Co., New York, 509 pp.

Davenport, C. B., and Castle, W. E.

'95 Studies in Morphogenesis, III. On the Acclimatization of Organisms to Dieudonné, A. High Temperatures. Arch. für Entw., II., pp. 236-240.

'94 Beiträge zur Kenntniss der Anpassungsfähigkeit der Bakterien an ursprünglich ungünstige Temperatur-verhältnisse. Arb. a. d. kais. Gesndhtsmt., IX., p. 492. 
Dorfmeister, G.

'79 Über den Einfluss der Temperatur bei der Erzeugung der Schmetterlingsvarietäten. Mittheil. naturw. Ver. Steiermark. Jahrg. I879, pp. 3-8.

Ehrenberg, C. G.

'59 Über eine auf der Insel Ischia jüngst beobachtete zur Erläuterung einer ungarischen aus Kiesel Organismen bestehenden Felsart dienende Wirkung heisser Quellen. Monatsber. Akad. Wiss. Berlin aud d. Jahre I858.

Féré, C.

'94 Note sur l'influence de la Temperature sur l'incubation de l'oeuf de poule. Jour. de l'Anat. et de la Physiol., XXX., pp. 352-365.

Flourens, M. J. P.

'46 (Note on Conferva of Icelandic hot springs.) Comp. Rend., XXIII., p. 934 .

Geppert, J.

'89 Über das Wesen der Blausaürevergiftung. Zeitschr. f. klin. Med., Bd. I5.

Haas, A. R.

'I6 A Simple and Rapid Method of Studying Respiration by the Detection of Exceedingly Minute Quantities of Carbon Dioxide. Science, N. S., Vol.

Hofmeister, W. XLIV., No. II25, pp. 105-I08.

'67 Die Lehre von der Pflanzenzelle. Leipzig. Engelmann, 664 pp.

Hyman, L. H.

'I6a An Analysis of the Process of Regeneration in Certain Microdrilous Oligochaetes. Jour. Exp. Zoöl., XX., 2, pp. 99-163.

' $16 \mathrm{~b}$ On the Action of Certain Substances on Oxygen Consumption. Am. Jour. Phys., Vol. 40, 2.

Knowlton, F. P., and Starling, E. H.

'I2 Influence of Temperature and Blood Pressure on the Isolated Mammalian Heart. Jour. Phys., 44.

Lillie, F. R., and Knowlton, F. P.

'97 On the Effect of Temperature on the Development of Animals. Zoöl. Bull., I., pp. I79-193.

Loeb, J., and Wasteneys, $\mathrm{H}$.

'I2 On the adaptation of fish (Fundulus) to higher temperature. Jour. Exp. Zoöl., XII., p. 543.

Mayer, A. G.

'I7 Is Death from High Temperature due to the Accumulation of Acid in the Tissues? Am. Jour. Phys., XLIV., 4, pp. 581-586.

Nägeli, C.

'6o Ortsbewegungen der Pflanzenzellen und ihrer Theile. Beitr. z. wiss. Bot., II., pp. 59-108.

Rossbach, M. J.

'72 Die rhythmischen Bewegungserscheinungen der einfachsten Organismen und ihr Verhalten gegen physikalische Agentien und Arzneimittel. Verh. phys. med. Ges., Würzburg, I, pp. 179-242. Also in Arbeiten a. d. zoöl.

Sachs, J. zoot. Institut', Würzburg, I., 9-72.

'65 Handbuch Exp. Phys., p. 52.

Schottelius, M.

'87 Biologische Untersuchungen über den Micrococcus Prodigiosus. Leipzig. 
Schultze, M.

'63 Das Protoplasma der Rhizopoden und der Pflanzenzellen. Leipzig, Engelmann, 68 pp.

Schwartz, F.

'84 Der Einfluss der Schwerkraft auf die Bewegungsrichtung von Chlamidomonas und Euglena. Ber. bot. Ges., II., pp. 5I-72.

Snyder, C.

'08 The Temperature Coefficient in the Velocity of Nerve Conduction. Am. Jour. Phys., 22, p. I79.

\section{Tashiro, S.}

'I4 Carbon Dioxide Apparatus. III. Another special apparatus for the estimation of very minute quantities of carbon dioxide. Jour. Biol. Chem., XIX., p. 485 .

Treviranus, G. R.

'3I Versuche über das Atemholen der niederen Tiere. Unters. über d. Natur. d. Menschen, d. Tiere, u. d. Pflanzen. (Tiedemann \& Treviranus), IV., pp. I-39.

Van Slyke, D. D., and Cullen, G. B.

'I4 The Mode of Action of Urease and of Enzymes in general. Jour. Biol. Chem., XIX., p. I4I.

Velten, W.

'76 Die Einwirkung der Temperatur auf die Protoplasma-bewegung. Flora LIX., pp. I77-I82, I93-I99, 209-217, April-May.

Verworn, M.

'99 General Physiology. Transl. by F. S. Lee, London. MacMillan \& Co., 6 5 pp. (pp. 389, 390).

\section{Weismann, A.}

'95 Neue Versuche zum Saison-Dimorphismus der Schmetterlinge. Zoöl. Jahrb., Syst., VIII., p. 4I et seq. 



\section{BIOLOGICAL BULLETIN}

THE RELATION OF THE EMBRYO TO THE PRINCIPAL AXIS OF SYMMETRY IN THE BIRD'S EGG.

GEORGE W. BARTELMEZ,

From the Department of Anatomy, The University of Chicago.

Contents.

I. The Fundamental Relations of the Various Parts of the Bird's Egg.... 319

II. Historical Review. . . . . . . . . . . . . . . . . . . 324

A. The Principal Egg Axis ...................... 324

B. The Air Space............................. 324

C. The Shell Pigment............................. 333

D. The Chalazæ............................. 325

E. Ligamentum Albuminis........................ 328

F. The Long Axis of the Yolk .................... 328

G. The Oviducal and Ovarian Orientation.............. 334

H. The Relation of the Embryo to the Principal Egg Axis: Axis Angle............................... 335

III. Axis Angles in the Pigeon's Egg... . . . . . . . . . . . . . . . . 339

IV. Discussion........................... 347

A. Variability in Axis Angles. . . . . . . . . . . . . . 347

B. Inversions .............................. 349

C. Variability in the Chalazæ..................... 353

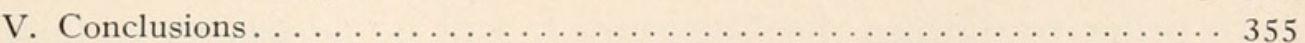

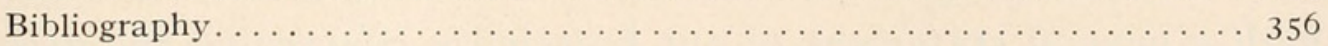

While studying the earliest stages in the development of the pigeon's egg some years ago it became necessary to devote some attention to the laid egg. Here I found several relations of fundamental importance which recent embryologists have consistently neglected. It was especially interesting to find that the well-known relation between embryo and egg as a whole (Fig. I) is subject to much greater variation than is generally believed. This became still more striking when it was found that the eggs of a single bird vary less than the eggs obtained from a group of birds. The present report covers observations extended over a much longer period than my former one (I9I2), together with an analysis of the data and the literature. 
I wish to call particular attention to the older studies on the bird's egg. From the time of Aristotle until the work of Kölliker, O. Hertwig and van Beneden began, the only accredited and accessible embryological material was afforded by the hen's egg and a wealth of observation was accumulated concerning it. Yet recent students of the bird's egg have dated their work from Gegenbaur's paper in I86I assuming that the monumental researches of Harvey, Malpighi, Wolff, Dutrochet, Coste and even Purkinje and von Baer have now only an historic interest. The folly of this will appear from what follows. These workers, unhampered by our elaborate technical methods, studied this macroscopic egg with the thoroughness of studious leisure and then wrote of it in a manner that must arouse the wonder and admiration of any embryologist today. The neglect which Purkinje has suffered can be explained at least in part, but the oblivion in which v. Baer's work still languishes is incomprehensible.

The findings reported here are significant not alone in illuminating the nature and causes of the variability in the relations of the axes of bilaterality. They have also a direct bearing upon all descriptive studies of the earliest stages of the bird's egg and they must especially be taken into account in the interpretation of experimental studies of stages preceding the appearance of the primitive streak.

In order to discuss the literature it will be necessary to begin with a general statement of our knowledge concerning the axes of the bird's egg, working backwards from the incubated egg to the ovarian oöcyte.

After the appearance of the primitive streak the bird's egg presents two obvious axes of symmetry; one a general axis of the egg as a whole, the principal axis, the other the axis of the embryo itself. Both of these are more or less apparent in other eggs, especially the highly meroblastic eggs of reptiles and selachians, but so far as is known it is only in birds that these two axes are definitely related to one another. The fact that they are related indicates that they are expressions of the same (bilateral) symmetry of the organism-a thesis for which I brought forth abundant evidence in I9I2. Unfortunately we 
have few data as to the relation of the two axes in birds other than the hen and pigeon but such observations as we do have indicate that many if not all birds' eggs show the same general relations. Duval in 1884 assumed this to be true but he never published any evidence.

The principal egg axis is defined by the form of the secondary egg envelopes. In addition to the obvious difference between the two ends of the shell, the ends of this axis are differentiated by even more constant characters like the position of the air space, pigment distribution in certain forms, and less dependable

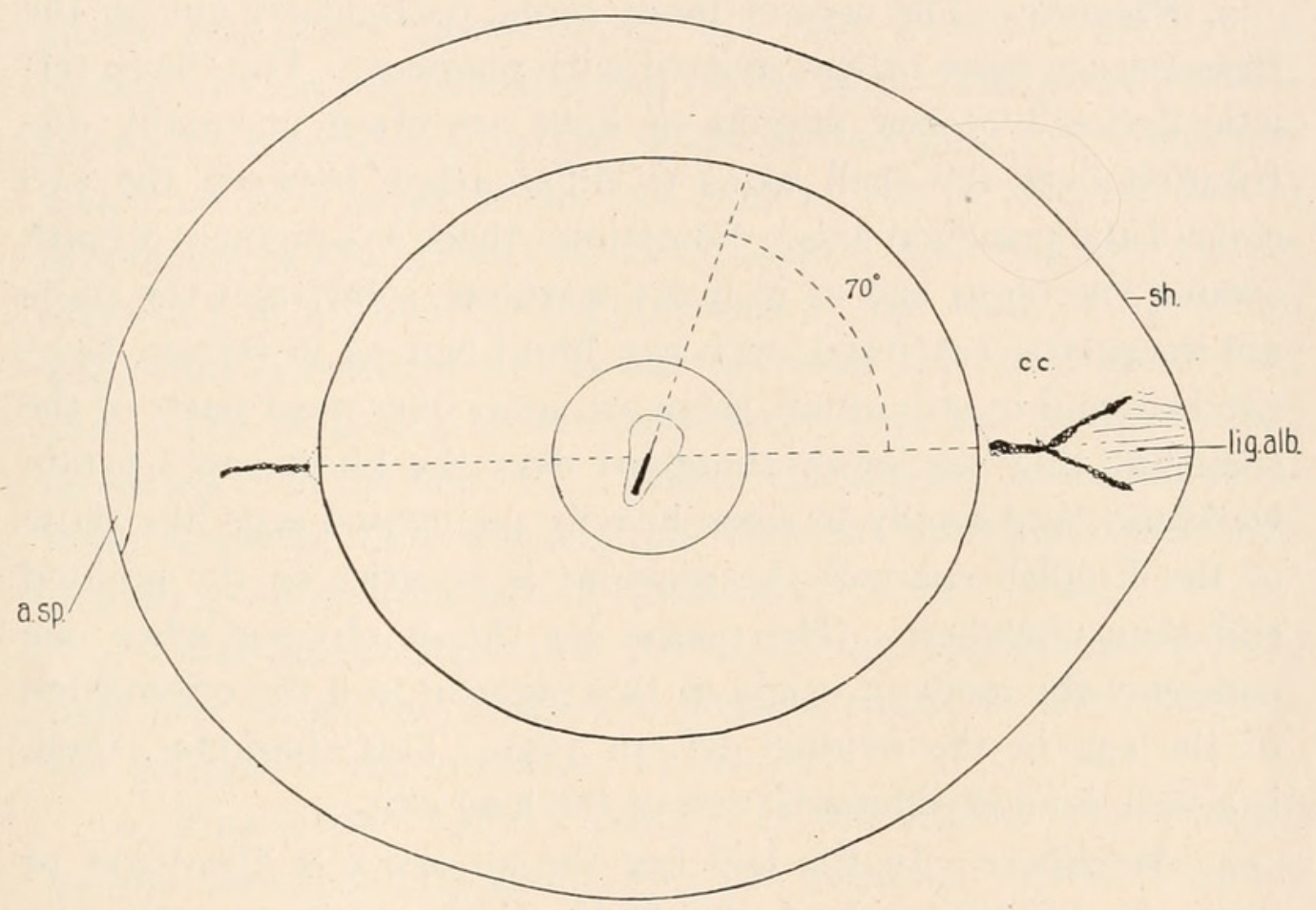

FIG. I. A diagrammatic polar view of an entire pigeon's egg showing the relation between the embryonic axis and the various features of the principal egg axis. The right side of the embryo is nearer the end of the egg which passed first down the oviduct, $i$. e., the pointed end of the shell. In the "uterus" the pointed end of the shell is directed toward the cloaca, the blunt end with the air space toward the infundubulum of the oviduct. The principal egg axis, ( $-(-)$ is marked by the major axis of the shell, the air space (a.sp.), the ligamentum albuninis (lig.alb.), the chalazal axis (c.c., cloacal chalaza), and the long axis of the ovum.

characters such as the size differences between the chalazæ. All of them are expressions of the structure and activity of the oviduct and their relations are constant because the egg is definitely oriented in the oviduct. As this point of view is new 
it is necessary to call to mind these characters and their relations to one another.

The two ends of the principal egg axis are differentiated by the following characters:

I. The relation of the embryo to the principal axis is such that its right side is nearer one end of this axis, its left side nearer the other.

2. Shape of Shell.-The two ends of the shell differ from one another in the eggs of most birds so that we may usually speak of a blunt and a pointed end.

3. Pigment.-The eggs of many birds, particularly among the Passeres are more or less spotted with pigment. The characteristic flecks, blotches, streaks or lines are often unequally distributed over the shell so as to differentiate between the two ends of the principal axis. Sometimes there is a pigment wreath around the blunt end as in many warblers, sometimes the spots are irregularly scattered over the blunt end as in certain flycatchers and in still others there are spots over most parts of the shell but they are more abundant over the blunt end (certain warblers), and finally in some heavily pigmented eggs like those of the English sparrow the pigment is scantier at the pointed end than elsewhere. The reason for this is obvious when one considers the mode of origin of this pigment and the orientation of the egg in the oviduct (cf. p. 333). This character, then, is a well-defined differentiation of the long axis.

4. Air Space.-In the laid egg the air space is always at or near the blunter end of the shell. This is an exceptionally constant character.

5. Chalaza.-The chalazæ are normally attached to the yolk in the line of the principal axis so that the chalazal axis is merely another expression of this axis. Furthermore, one often finds that one chalaza is larger and more distinct than the other. It is almost invariably the one at the pointed end of the shell. During incubation the blunt end chalaza is more likely to become detached or to disappear entirely; that is to say it reverts more readily to the sol phase.

6. Ligamentum Albuminis.-The second or thicker albumen is more or less firmly attached to the inner shell membrane, 
usually at both ends of the shell but this prolongation through the outer thin albumen is more marked at the pointed end in the laid egg. This prolongation Tredern fancifully called a "ligament."

7. Long Axis of Yolk.-The striking fact that the yolk (ovum) is not a sphere has been generally overlooked. One of its axes is greater than either of the other two and this axis is perpendicular to the polar axis and coincides with the principal axis.

8. The Oviducal Orientation.-All of our evidence points unmistakably to the conclusion that the pointed end of the egg passes first down the oviduct. We may therefore speak of a cloacal and an infundibular end of the egg. The principal axis therefore, coincides with the oviducal axis and the differences which we find between the two ends of the former are due to differences in the activity of the oviduct. The long axis can be identified in all ovarian oöcytes and at the time of ovulation the ovum is oriented in the oviduct with reference to its long axis. The long axis accordingly determines the principal axis as we see it in the laid egg. These relations are of fundamental importance for they demonstrate that the embryo is definitely related to an ovarian axis of symmetry.

9. I was able to show that the end of the long axis which is to pass first down the oviduct is predetermined in the ovary by the position of the latebra of Purkinje.

I0. Finally the eccentric position of the latebra is determined by the corresponding position of the germinal vesicle in young oöcytes.

In view of these facts we may express the relation between egg and embryo thus: The right side of the embryo is nearer that end of the principal egg axis which is predetermined in the ovary to pass first down the oviduct. This holds of course only for stages previous to the turning of the embryo on its side. To state the case in the more usual way we should say: If the end of egg which is predetermined to pass first down the oviduct be held to the observer's right the head of the embryo will be directed away from him. The presence of an axis of symmetry in the ovarian oöcyte so definitely related to the embryonic axis naturally led me to look for morphological evidences of the embryonic axis 
itself. The evidences I found in ovarian and oviducal eggs were enumerated in my I9I2 paper and I hope soon to publish the details of these observations.

\section{Historical Review.}

A. The Principal Axis of the Egg.-Aristotle devoted much attention to the hen's egg and he speculated at length upon the difference between the two ends of the shell. The Aristotelian doctrine, which is to be found elaborated even in some relatively recent papers may be stated as follows: The ovum drops into the oviduct as an apple from the tree; the ovarian pedicle of the oöcyte becomes the pointed end chalaza which passes last down the duct and the theca folliculi becomes the shell membrane. The pointed end is the "principium ovi, where the first rudiments of the egg are fashioned." This philosophy was based chiefly upon two observations of Aristotle's: The ovarian stalk or pedicle is characteristically long in the hen's oöcyte and the blunt end of the egg is laid first. Harvey's account of the early development is the first clear and accurate one for he understood the nature and destiny of the "cicatricula." He was able therefore to correct the error concerning the "principium ovi" as well as many others which his predecessors had made. However much he chuckled over the blunders of others, Harvey was always at some pains to explain or extenuate the errors of the Great Master. His discussion of Aristotle's statement that the shell does not harden until it reaches the outer air is well worth reading (I65I, Exercitatio XI.).

B. The Air Space.-Harvey was the first to observe the air space carefully; he found it at or near the blunt end of the hen's egg and he cites a common belief that if it is at the center of the blunt pole a male will be produced. He describes it as very small at laying, growing larger as incubation advances. v. Baer (I828) was the first to note that it is not present at all in oviducal eggs nor at the moment of laying. Coste ( 1847 , p. 306) is the only one apparently, who has seriously considered the problem of the air space. He confirmed v. Baer's observations and showed that as the egg cools after laying atmospheric air enters through the shell and forms the space between the two layers 
of the shell membrane. He did this by killing a hen that was about to lay, ligațing the uterus at either end and immersing the whole in a dish of oil. The uterus was then removed and the next day an oil-filled cavity was found in the place of the air space. But why should this space always arise at the blunt end? Coste was able to produce it under any part of the shell by a modification of his procedure. If, instead of removing the uterus under oil he clipped a window in it (thus exposing any given area of the shell) he obtained a typical oil-filled cavity under the window between the shell membranes. He was not able to explain why it normally forms where it does. Valentin (I835, p. 30) had previously attributed the formation of the air space to the puckering of the oviducal walls at the junction of "isthmus" and "uterus." He cites Purkinje to this effect but I have not found any mention of the matter in either edition of his paper. The region of the shell where the space forms is obviously more porous, quite possibly for the reason which Valentin gives. I have made some preliminary tests and am inclined to think that the shell cuticle is concerned in this localization.

It would be interesting to know whether there is any connection between the position of the air space and the fact noted by Murray (I826) that the temperature of the albumen at the blunt end is higher than that of the other.

All birds' eggs which I have examined have the air space at or near the blunt end of the shell. This holds for all pigeons' eggs in which a more pointed end is distinguishable. Some pigeons' eggs, as Coste noted, have equally rounded ends. In such eggs we find the head of the embryo turned away when we hold the air space end to our left. The practical importance of this for the present study is obvious (see p. 34I).

C. Shell Pigment.-See discussion on p. 333.

D. The Chalaze.-v. Baer says (1837, p. I8), "ueberhpaut ist nichts im Ei so wechselnd als die Hagelschnüre." Previous to I 850 this variability gave occasion for much study and controversy concerning chalazæ. The earliest workers were quite in the dark as to their nature. Aristotle was the first to refer to them and he thought one of them identical with the stalk of the 
ovarian ovum as has been said. The echoes of this opinion did not die out until quite recently; witness the belief that the inner shell membrane is identical with the theca folliculi interna of the oöcyte, an idea advanced by Pander (I8I8), Meckel v. Hemsbach (I85I), Mayer (I865), Nathusius (I885) and others. Needless to say none of these workers had any accurate knowledge of the oviducal egg of any bird. The theory was however not conclusively refuted until I884 when Tarchanoff succeeded in inserting an amber bead into the oviduct of a laying hen and twenty-four hours later found it surrounded by albumen, shell membrane and shell (cf. Curtis, I9I4).

Aldrovanus considered the chalazæ to be the sperm of the cock and Fabricius ab Aquapedente (I625) had a similar idea for he supposed that they were added at the time of fertilization. He considered one of them as the first rudiment of the embryo and drew excellent figures of chalazæ which have a ludicrous resemblance to chick embryos of the fourth day. Wolff in 1764 confesses to having made the same error in his own juvenile studies of the hen's egg. Harvey was the first to give a correct account of the nature and functions of the chalazæ. However he says that the chalaza at the blunt end of the egg is greater and longer than the other, differing in this from all subsequent observers.

A word should be said at this point concerning the various layers of albumen found in the bird's egg. Immediately surrounding the yolk and intimately fused with the vitelline membrane is the chalaziferous albumen which is continuous with the chalazæ. Around this is a layer of fluid albumen which makes possible the independent rotation of the yolk. Next follows the dense albumen which at laying is attached to the shell membrane at either end of the shell (ligamentum albuminis) so that the chalazæ are surrounded by the dense albumen. The space between this layer and the shell membrane is filled for the most part by a very fluid albumen which runs out as soon as the shell is opened. The inner thin albumen is difficult to identify in the laid egg of the hen (cf. Curtis and Pearl, I9I2, p. I02) but Doctor Blount tells that this albumen is very obvious in the "uterine" egg of the pigeon. This is obviously an egg in which the origin of the chalazæ can be most readily studied. 
The development of the chalazæ was first described by Dutrochet (I8I8-I9). His work was confirmed and extended by Purkinje (I825), v. Baer (I 828 and 37) and Berthold (I829) among others. The albumen which at first surrounds the newly escaped ovum forms a thin but dense layer over its surface. This albumen is probably secreted according to Curtis (I9I5) in the infundibulum and neck of the duct. It coagulates into the membrana chalazifera Dutrocheti and is shortly so firmly united with the vitelline membrane that they cannot be separated. "The tendency, says v. Baer, of albumens in contact with solids to coagulate is well known." The chalaziferous membrane is directly continuous with strands of albumen which were secreted into the lumen of the oviduct above and below the ovum. These strands, attached as they are to the ovum, become the chalazæ. According to Coste (I 847 , p. 29I) the ovum is not free to orient itself with reference to gravity until a fluid layer forms between the chalaziferous albumen and the inner dense albumen probably during the period of shell formation in the "uterus." This might happen while the thin solution of albumen is passing through the developing shell as described by Pearl and Curtis (I9I2). While in the uterus the egg is constantly being turned on its long axis and the ovum is constantly tending to orient itself with reference to gravity since the animal pole is specifically lighter than the yegetal. Consequently the chalazal strands attached to the yolk become twisted in opposite directions and as a result there is a partial coagulation of the chalazal albumen resulting in the "hailstones."

The stage at which the yolk is first free to rotate independently of the surrounding thick albumen and the time when the chalazæ as such become visible have not been satisfactorily determined. The nature of the space, too, between the chalaziferous albumen and the inner albumen which makes the rotation possible is most obscure. The suggestion of Taschenberg (1885), that the twisting of the chalazæ takes place before the egg enters the uterus is highly improbable. Not infrequently in the hen and pigeon at least, there is more chalazal albumen below the ovum than above it as Purkinje first noted (I825) and consequently the cloacal chalaza is larger than the other. This condition may play 
a part in the differentiation of the two ends of the shell. I have records of 14 oviducal pigeon eggs which had more albumen cloacally of the ovum but no instance of the converse. Many observers have noted for the hen that the pointed end chalaza may be larger than its mate in the laid egg. Thus: Maitre Jan (I722, p. I6), Leveille (I 799, p. 53), Vicq d'Azyr (I805) who says that the chalaza at the pointed end is "ordinairement" greater than the other, as well as Purkinje (I830, p. I8), v. Baer (I828), Berthold (I829) and Coste (I847, p. 293). Occasionally the infundibular chalaza is wanting in the incubated egg or is represented by a small button or cap of denser albumen (cf. Dutrochet (I8I8), Purkinje, I 830, p. I8). My own observations for these points are tabulated on p. 354. Since any difference in size or distinctness of the chalazæ is practically always in favor of the cloacal (pointed end) chalaza, we may say that a difference in the chalazæ is a frequent differentiation of the principal axis.

E. Ligamentum Albuminis.-Tredern's original description of the ligamentum albuminis occasioned much interest and controversy soon after its publication in $\mathrm{I} 808$ but recent generations seem to have forgotten it entirely. It is familiar to all who have opened fresh eggs at home with a view to strict economy. It should be said that usually it cannot be made out in stale or incubated eggs; there is in fact the same reversal from gel to sol phase in the denser albumen which may occasionally be observed in the chalazæ. This tendency is much more marked in the sparrow's than either the hen's or the pigeon's egg so far as my observations go.

F. The Long Axis of the Ovum.-There are two opinions as to the shape of he yolk of the bird's egg. One is the common traditional view, namely, that it is a sphere. Thus Harvey, transcribing his discussion of the yolk largely from Aristotle describes its shape as "perfectè rotundus." Likewise Haller (I758) and Vicq d'Azyr (I805) refer to "la forme spherique du jaune." Pander is one of the careful observers who makes a similar statement and even in Coste's beautiful figures (I 847), the outline of the yolk is always a circle. Purkinje himself seems to intimate that the yolk in the laid hen's egg is spherical as his collaborator Valentin (I835) did and as most moderns do, to 
judge from their diagrams. Other workers seem to have doubted this tradition. Bonnet ( $\mathrm{I} 762$ ) says, "La jaune est un grand sac, a peu pres rond" and Home (I 822) comments upon the "oval shape of the yelk." The figures in Tredern's paper and in Duval's Atlas (I 888) show the long axis. Now far from being spherical the yolk has not only a longest axis perpendicular to the polar axis but it is usually somewhat flattened at the animal pole so that the polar is its shortest axis. von Baer was the first to describe accurately and understand the significance of the shape of the yolk. Two passages are particularly worth quoting. They were written soon after the appearance of the first part of his great "Ueber die Entwickelungsgeschichte der Thiere" in I 828 although they were not published until i 837 . Thus on page I4 he says: "Ihre (der Dotterkugel) Form ist nicht völlig kugelig, sondern ellipsoidisch, indem ihre längste Axe wie die längste Axe des Eies gerichtet ist." Again, page 29, "Da die Dotterkugel im Eierstocke so liegt, dass die Keimschicht fast immer dem Stiele des Kelches zugekehrt ist, da ferner die trichterförmige Mündung des Eileiters den Kelch von der Seite umfasst, so tritt die Dotterkugel in solcher Lage in den Eileiter ein, dass die Keimsicht nicht vorn oder hinten ist, sondern an der Seite. Vorzüglich wird aber diese Stellung dadurch bedingt und mehr gesichert, dass diejenige Axe, die von der Keimsicht durch den Mittelpunkt des Dotters geht, auffalend kürzer ist als die senkrecht auf dieser Axe stehende. ${ }^{1}$ Letztere wird daher bald in die Längenrichtung des Eileiters gestellt werden, wie auch der Dotter eingetreten seyn mag.

This remarkable description, which may be confirmed by anyone who will make careful measurements, has been almost universally ignored. While $\mathrm{v}$. Baer was the first to see that the ovum orients itself with reference to its long axis in the oviduct-

\footnotetext{
${ }^{1}$ Hiernach wird es auch verständlicher, warum die Keimschicht, wenn sie nicht in der Nähe des Stieles vom Kelche ist, sich zuweilen in der Narbe zeigt. Sie bleibt nämlich im Kleinsten Kreise des Dotters. In ganz kleinen Eiern von der Grösse eines Hirsekornes habe ich diese längliche Gestalt nicht mit Sicherkeit zu erkennen vermocht. Sollte sie schon da seyn, so könnte man vielleicht sagen, dass das Keimbläschen gegen die nächste Stelle der Oberfläche des Eies sich bewegt und eben deshalb die Centralhöhle, als urpsringlicher Sitz des Keimbläschens, der Keimschicht (einer Wirkung des Keimbläschens) näher liegt, als der entgegengesetzten Seite. (See Bartelmez, I912, pp. 287 and 295.)
} 
he thought after ovulation, it must nevertheless be remembered that practically every objective drawing of an entire ovarian oöcyte shows a well-defined long axis. Pfeil describing a mature oöcyte of the hen in I823 says ". . . vitello in sacco scilicet rotundo, globoso" and Purkinje in I 825 (p. I) mentioned the 'somewhat oblong' shape of the young oöcytes. He saw also the elongate shape of the mature oöcyte but thought it was due to the pressure of the oviduct (see pp. 9 and 20, I830 edition).

Allen Thompson (I839) and Balfour (I874) completely confirmed von Baer's description while several workers have described the long axis in ovarian oöcytes of the hen without recognizing its significance. The following may be mentioned: His (I868), Nathusius (I868), Sonnenbrodt (I908) and Riddle (I9I I).

The observations of Haswell ' I 887) are particularly significant in this connection. With $\mathrm{v}$. Baer's description in mind he studied the egg of the emu, found the yolk measuring $70 \times 75 \mathrm{~mm}$., the long axis coinciding with the principal axis and the relations of the embryo as they are in the hen. He found the yolk ovoid rather than oval in shape, the more pointed end corresponding to the pointed end of the shell. I have occasionally seen the same condition in the pigeon's egg, but in this form attached no particular significance to it, as in some such cases the more pointed end was directed toward the blunt end of the shell.

In the pigeon the yolk is more markedly elliptical than in the hen and since it does not lose its shape through imbibition of albumen during the first two days of incubation as the hen's egg is apt to do, the long axis can hardly escape notice. It averages ten per cent. longer than the other axes of the yolk (see p. 342). It was a matter of no small gratification to find three years after writing it that I had almost duplicated v. Baer's description of the orientation of the hen's egg in my account of the pigeon's egg (I9I2). In his day the problems of bilaterality had not yet come to the fore and so he did not take the next logical step and point out the significance of the fact that the embryonic axis is definitely related to the ovarian long axis.

In most pigeon's eggs we find the polar axis the shortest; that is, in addition to being shorter than the long axis, it is usually shorter than the axis perpendicular to these two - which I term the transverse axis (Bartelmez, I9I2, p. 290 and p. 342 
below). Haller made mention of this in $175^{8}$ and Féré (1897) has called particular attention to it.

G. The Oviducal Orientation.-How does the egg lie in the oviduct? What is the relation of the principal egg axis with its differentiations to the axis of the oviduct? This has always been a matter of interest and it has been very naturally associated with the question as to which end of the egg is laid first. Aristotle says the blunt end is laid first and his whole argument concerning the "principium ovi" seems to assume that this end passes first down the oviduct. Purkinje published the data for the understanding of this matter in I 825 (see especially pages $2 \mathrm{I}$ and 22 of the 1830 edition) and he was fully confirmed by von Baer (I828-I837) and Coste (I847), but this was all forgotten and the question was discussed in the seventies and eighties to little purpose. It was finally put to rest by Wickmann in $\mathrm{I} 895$.

It should be said first that all observers who have made extensive studies of oviducal stages in birds agree that the pointed end passes first down the oviduct. For the hen the following may be cited: Purkinje (I 825 ), von Baer (I 828), Coste (I 847 , p. 293), Kütter (I878), Taschenberg (I885), Wickmann (I895) and Patterson (I9I0). In the pigeon the pointed end when recognizable was always found to be cloacal by Blount (I909) and Patterson (I909), each of whom studied about I50 oviducal eggs, and this has been my own experience. The same conditions have been reported for a hawk by Kütter (I878), the canary and various other birds by Wickmann (I895). It may be said in passing that Meckel von Hemsbach announced in $185 \mathrm{I}$ that it was a mathematical necessity for the blunt end to pass first down the oviduct! J. A. Ryder (I893) has also worked out the mechanics of shell formation on this basis.

There are however numerous observations which leave no doubt but that the blunt end of the hen's egg is usually laid first as Aristotle said. Nathusius gathered data in I885 and obtained only a single authentic record of the pointed end having been laid first. Landois (I877), König-Warthausen (I 885), Jasse (I886) and Erdmann (I886) all gave evidence from direct observations or from the direction in which the blood streaks of pullet's eggs were rubbed, that the blunt end is laid first. Nathusius (1885) reported a series of observations by Frau A. Ernst 
in Caracas upon 48 eggs laid on coal soot. It was clear that in every case the blunt end had been laid first.

It was assumed by these writers that the egg is forced out of the uterus in the act of laying by a simple peristalsis and hence that the blunt end passes first down the oviduct. Wickmann (1895) made direct observations upon the laying of eight hens and found that in most cases the blunt end is laid first; one hen however laid five successive eggs with the pointed end first. If the bird is taken some time before an expected laying the egg is always found with the pointed end cloacal, but, as both Purkinje and v. Baer noted, if she is killed near the time of laying either end may be directed toward the vagina. Purkinje suggested that during "labor" the egg was turned about its long axis until its position became "comfortable." He figured the oviduct of a hen with an egg in the "uterus" (Tab. II., Fig. I9), which shows the pointed end so held in a diverticulum of the duct that it is to the right and below the opening of uterus into vagina. Consequently the constant peristaltic movements of the duct rotate the egg without tending to drive it into the vagina. Wickmann (1895) was the first to analyze the whole process of laying. He demonstrated in a striking manner that in laying the egg is rotated about its shortest axis so that one end or the other lies opposite the opening into the vagina. Usually it is completely rotated so that the blunt end comes to be cloacal, occasionally there are birds in which the rotation is slight and the pointed end remains cloacal. Now a surprising thing happens. The egg is not simply forced out through the vagina as a mammal is born. The uterus still enveloping the egg is prolapsed through the vagina and the egg is laid without having touched the walls of either vagina or cloaca. Which end is laid first then depends upon chance or the peculiarities of the individual oviduct. There is then nothing to militate against the evidence that the end of the egg corresponding to the pointed end of the shell passes first down the oviduct and we may accordingly refer to this end as the cloacal end of the egg. Taschenberg (I894) states that certain individuals of Corvus frugilegus are apt to lay eggs with the pigment wreath at the pointed end of the shell, instead of the blunt end and that eggs may be found lying 
inverted in the "uterus" of this species. In such cases it is probable that the egg is rotated late in its uterine history.

Shell Pigment.--The unequal distribution of the pigment can now be discussed. While the method of distribution has been worked out satisfactorily, the origin of the pigment still remains obscure. As this field is terra incognita to most embryologists and ornithologists it is worth a digression. Wicke in 1858 laid the foundation for the understanding of the matter. He discovered that the pigment spots which are various shades of red or green, are closely related to or identical with the blood pigments bilirubin and biliverdin. Leuckart (I853) suggested that they might be derived from blood extravasated from the hyperæmic oviducal vessels. Kütter (I878) made the first direct observations on the subject. He found in the "uterus" of a Falco tinnunculus an unpigmented egg, although the eggs of this species are normally deeply pigmented. Scattered over the surface of the oviduct were small red-brown masses presumably passing down, for in other oviducts he found similar masses being incorporated into the outer layers of the shell. He suggested that these pigment masses were secreted in the upper part of the duct. In I 885 Taschenberg confirmed these observations and showed that there are no pigment glands in the oviduct, confirming Nasse's (I 862) previous observations. He concluded therefore that the pigment must be derived from the follicle at the time of ovulation. He pointed out for the first time the significance of the greater massing of pigment at the blunt end with reference to the passage of the pigment down the duct and the normal position of the egg in the uterus. It is obvious therefore that the unequal distribution of the pigment clearly marks the principal egg axis and shows that in all cases where there is unequally distributed pigment, the egg is oriented as it is in the hen and pigeon. In I 893 Wickman published a monograph on the pigment of the shell dealing with numerous species, confirming Kütter and independently reaching conclusions similar to those of Taschenberg. He did not however obtain any conclusive evid nce for the origin of the blood pigment from the ruptured follicle. This is an opportunity for an exceedingly interesting study involving also the nature of the oxidations of the blood pigments. 
The Oviducal Orientation.-We have seen that one end of the principal axis may differ from the other in regard to the shape and pigmentation of the shell, the position of the air space, the ligamentum albumenis, in the size and character of the chalazæ, and the relation of the egg to the oviduct. The vital link in the evidence for the thesis that the principal axis is an expression of an ovarian axis of symmetry was obtained when it was found that the end of the long axis of the yolk which is to pass first down the oviduct is predetermined in the ovary (Bartelmez, I9I2, p. 292 ss). In the pigeon at least, the latebra of Purkinje is, like the blastodisc, lighter than the mass of yellow yolk. Purkinje (I830, p. 7) believed the converse for he was much struck by the resemblance of his "fluid-filled cavity" to a plummet and did not make any tests. He did know however that the contents of the latebra have the same histological structure as the white yolk about the blastodisc. His figure (Tab. I., Fig. I6) of a median section of the yolk of a hen's egg shows the center of the latebra nearer the animal pole than the vegetal. This is still more marked in the pigeon's egg (see Bartelmez, I9I2, figs. 38 and 39). This specifically lighter latebra is nearer one end of the long axis than the other end and so one end of the ovum gravitates toward the cloaca and is received first into the oviduct as was described in my I9I 2 paper. It is worth noting that in three clearly objective drawings in the literature the latebra is shown nearer one end of the long axis of the hen's ovum; they are v. Baer's Figs. I and 2, Plate III. (I 828) and Duval's Fig. 2I (I889). This observation can be made with certainty only on oöcytes during the final growth period or shortly after ovulation. Eggs taken subsequently show more or less diffusion between latebra and surrounding yolk so that accurate measurements are usually impossible (cf. my figures just mentioned). Purkinje made mention of this fact in 1825 . It will be remembered in this connection that the yolk increases in weight as it passes down the oviduct, taking up water from the surrounding albumen during its progess (cf. Curtis, I9II).

Since I was able to show that the position of the latebra nearer one end of the long axis is determined by the corresponding position of the germinal vesicle in earlier stages it is possible to trace the principal axis with one end morphologically different 
from the other, to the youngest oöcytes in the ovary. These facts have been confirmed by my subsequent observations and the complete demonstration for the pigeon requires only experimental evidence.

H. The Relation of the Embryo to the Principal Egg Axis (Axis Angle).-Who was the first to describe this remarkable relation? No one has ever tried to find out. Duval (I 884) has often been given credit for it, but he was only one of the few who have published concrete data on the subject. These data and the use he made of them are largely responsible for the deeply rooted tradition of today that the embryo in the hen's egg lies at right angles to the principal egg axis. It speaks volumes for the mighty influence which the classic "Atlas d'Embryologie" has had upon all of us. Duval himself gives the credit to Balfour and Kölliker as Kionka also does in I894, but neither of these appears to have mentioned the matter except incidentally in their text-books. Dareste (I89I) and Rabaud (I908) attribute it to v. Baer. v. Baer wrote one of the best and most complete accounts that has ever appeared in the 1828 edition of his epochmaking work. It is difficult to understand how this discussion has come to be so completely forgotten. But v. Baer himself speaks of the relation as a matter of common knowledge at the time. The earliest mention I have succeeded in finding is in Pander's thesis (I8I7). In the German edition illustrated by D'Alton which immediately followed the original he says (p. 9): "Sobald die Längenpole des Embryo, welche nicht dem Längensondern dem Querdurchmesser des Eyes entsprechen gesetzt sind, entsteht zwischen den beiden Falten (des Primitifstreifens) der Länge nach, ein zartes, oben rundlich, unten lanzettförmig breiter Streifen, das Rudiment des Rückenmarkes." The casual nature of the statement leads me to think that he was merely stating an accepted fact which was not particularly significant for the matter in hand. As many workers before the day of physiological salt solution opened the egg at the broad end by way of precaution it may not have been discovered much before this time.

It is possible that Malpighi (I672) noticed the variability between the principal egg axis and the embryonic axis. In all of his figures the embryo is drawn with the head $u p$ on the page and in most it is parallel to the sides of the page. In certain 
young ones however (Tab. I., Figs. 2, 3, 5, 6 and 7 and Tab. II $a$, Fig. I) the long axis of the embryo is inclined to the vertical. In all but one of these the angle is less than $90^{\circ}$. As it is probable that he drew all the younger blastoderms in situ on the yolk, it may be that they had been oriented with reference to the chief shell axis. I did not find any reference to this point in the text.

The relation is best summed up in the words of v. Baer (I828, p. I2):

"Lage des Embryo.-Um die vierzehnte oder fünfzehnte Stunde tritt das erste Rudiment des Embryo auf. Dieses besteht keinesweges in den beiden Primitivfalten Pander's, sondern in einem mittlern Streifen, der etwa I I $/ 2$ Linie lang ist, und den ich Primitivstreifen nenne. Er ist der Vorläufer der Wirbelsaule und liegt in der Längenachse des durchsichtigen Fruchthofes. Die Längenachse des Fruchthofes entspricht aber nicht der Längenachse des Eies, sondern der Querachse desselben, und zwar liegt der Kopf des zukünftigen Embryo, der in dem ersten dunklen Streifen schon durch ein etwas dickeres Ende angedeutet wird, nach links, das Schwanzende nach rechts, wenn man das $\mathrm{Ei}$ in seiner Längenachse so vor sich stellt dass das stumpfe Ende dem Beobachter zu- und das spitze Ende abgekehrt ist, der Keim aber nach oben liegt. Hiernach ist die linke Seite des Embryo nach dem stumpfen Ende des Eies gerichtet, die rechte nach dem spitzen Ende. Indessen ist diese Lage nicht immer so bestimmt, dass die Längenachse des Embryo mit der Längenachse des Eies genau einen rechten Winkel bildete, der Winkel weicht vielmehr so ab, dass die erstere bald auf der einen, bald auf der anderen Seite sich mehr der letztern nähert, so dass, freilich in sehr seltenen Fällen, beide Achsen fast zusammenfallen können, wobei dann der Kopf des Embryo bald dem stumpfen, bald dem spitzen Ende des Eies zugekehrt ist. Nur einmal fand ich den Embryo umgekehrt liegen, so dass sein Kopf in der Hälfte des Eies lag, in der das Schwanzende hätte liegen sollen."

The first writer who gave statistics on axis angles is Dalton (I88I). He made observations on Ioo hen's eggs holding the pointed end of the shell to the right and noting in which octant the head lay; in other words he grouped his observations in $45^{\circ}$ classes. I have transposed his data so that they may be directly compared with my own. 


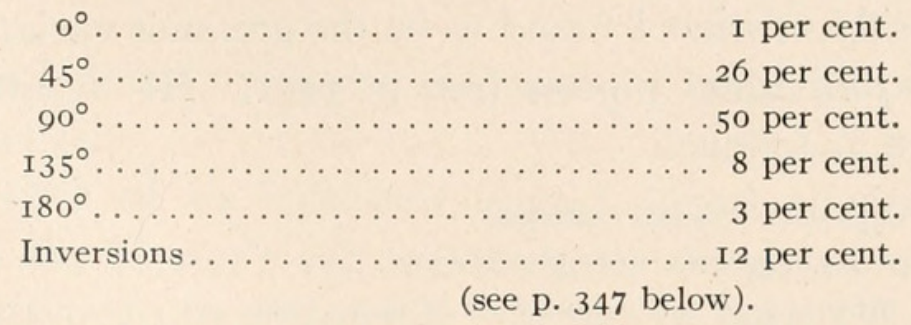

Dalton also took cognizance of the relation between the ovum and the embryo for he suggests that the position of the embryo on the yolk may be due to the way in which segmentation takes place in the "cicatricula"-referring to Kölliker's suggestion regarding the eccentricity of cleavage. He then remarks that variation in the relation of the embryo to the shell may be due to the manner in which the yolk is received and transported through the oviduct. He at least, had not failed to read v. Baer.

Duval (I884) who does not seem to have ever seen "Ueber die. Entwickelungsgeschichte der Thiere" and who speaks of "la loi énoncée par Balfour," was the first to make practical use of the axis angle. He saw that it afforded a means of orienting stages previous to the appearance of the primitive streak and accordingly made a "petite statistique" upon I66 hen's eggs incubated 39 hours. He observed the angle between embryo and shell and to judge from his diagrams grouped them in the following classes:

$\begin{array}{rrrr}90^{\circ} & \text { I } 24 \text { eggs } & 76 \text { per cent. } \\ \text { circa } 65^{\circ} & \text { I3 “ } & 8 \text { per cent. } \\ \text { circa } 110^{\circ} & 26 “ & \text { I } 6 \text { per cent. } \\ 180^{\circ} & 2 \text { “ } & \text { I per cent. } \\ \text { (Inversion) } 270^{\circ} & \text { I egg } & \text {. } 6 \text { per cent. }\end{array}$

The large number of cases at or very near $90^{\circ}$ may be due partly to the personal equation for which there are many loopholes in his method of measurement, partly perhaps to his having obtained his eggs from a small flock of hens.

Féré (1900) published the most extensive data that have appeared on the hen's egg, in connection with his demonstration that such experimental eggs as develop normal embryos have no more variation in the axis angles than the controls do. His results are tabulated as percentages of "deviations." He considers all cases which show a variation of $45^{\circ}$ or more from the "norm," as "deviations." Expressed in my terms this means there is a normal variation of $90^{\circ}$, from 45 to $\mathrm{I} 35^{\circ}$ which corre- 
sponds exactly to what I found to be the greatest variation in the eggs of an individual pigeon (see p. 347). His results may be summarized as follows:

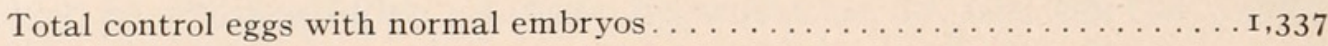

Total experimental eggs with normal embryos . . . . . . . . . . 588 Percentage of normal eggs with deviation of more than $45^{\circ} \ldots \ldots 2$ I.39 per cent. Percentage of experimental eggs with deviation of more than $45^{\circ} \ldots 28.82$ per cent.

In 1908 Rabaud published an exceedingly interesting study upon variation of axis angles in the hen's egg. He determined first from a series of I05 eggs taken at random that as much variation might be met with normally as was reported by Féré, Blanc, and Ferret et Weber in their experimental series. This is shown in the following tabulation of his results:

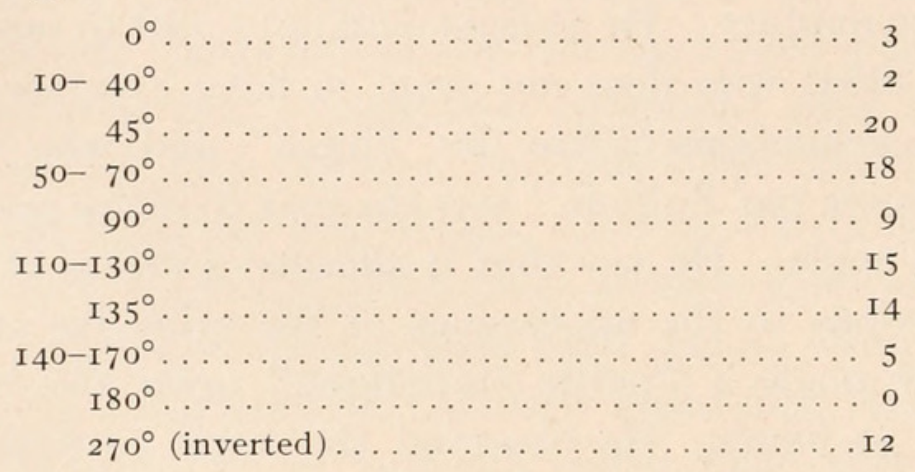

Rabaud showed also by a series of observations on over Ioo eggs with windows in the shell that in the course of the first five or six days' incubation the axis angle does not change.

For the pigeon Patterson (I909) gives the usual axis angle as $45^{\circ}$ (see my I9I2 paper, p. 300), whereas Blount (I909) mentions variations such as $60^{\circ}$ and $150^{\circ}$, but regards these as "comparatively rare." My own results which showed much greater variability for the pigeon's eggs and indicated less variability for the eggs of a given bird are discussed on page 347 below.

The only other reports on the relation of embryo to egg in birds are those of Haswell (I887) for the emu and Féré (I 896) for the duck. The former found all the relations described by v. Baer for the hen's egg. The embryo was "usually at right angles" but "not infrequently oblique though never longitudinal" to the principal egg axis. Féré (I 896) compared the axis angles in the duck with the hen and found they agreed except that the duck showed greater variability. In a series of 74 eggs of each kind, 75 per cent. of the duck eggs showed a 
"deviation" of $45^{\circ}$ or more as compared with 30 per cent. of the hen's eggs.

In a clutch of six sparrows' eggs I found all the relations typical of the pigeon's egg including the long axis of the yolk and the ligamentum albumenis. In two of these the axis angle could be measured and was found to be $45^{\circ}$ in one, and about I $25^{\circ}$ in the other.

\section{Axis Angles.}

Before considering the relations found in the eggs of the individual birds it is necessary to consider the normal range of variability in the pigeon's egg. The curve, Fig. 2, shows that the variability is great, in fact, one may meet with almost any angle from $o$ to $\mathrm{I} 80$ degrees. The extremes met with were 3 and $\mathrm{I} 80^{\circ}$ both of them in eggs which had abnormal chalazæ and were therefore not included in the curve. The latter is unique as there were no cases found between $135^{\circ}$ and $\mathrm{I} 80^{\circ}$. All similar cases in which the absence of well marked long and chalazal axes made it impossible to measure the angle accurately were omitted, thus eliminating about 7 per cent. of the eggs studied. As is indicated in the curve, the maximum variation was $127^{\circ}$ in normal eggs; there were two cases at I 35 and one at $8^{\circ}$, all three of them perfectly normal typical eggs in other respects.

The curve of axis angle variability which I published previously (p. 303) shows four modes. These seemed to indicate that a flock of birds could be divided into groups laying eggs with similar angles. In plotting the present more extensive data the curve (Fig. 2) has been compressed by making Io instead of 5 degree classes and it suggests another interpretation. It shows a resemblance to a curve of normal variability with its mode at $70^{\circ}$ and were there several thousand instead of a trifle over five hundred cases I believe the resemblance would be much more striking. It suggests in other words that the actual angle between embryo and principal axis is a matter of chance. It should be noted that 85 per cent. of all cases lie between 45 and $90^{\circ}$. This means that in the pigeon egg the right side of the embryo is practically always (98 per cent.) directed toward the pointed end of the shell, but that in addition the head is usually inclined in the same direction. Obviously Patterson (I9I0) was correct as to the essential relation between the pigeon embryo 
and the chalazal axis but the axis angle is usually greater than he believed. We cannot be more specific concerning the axis angle in the pigeon than to say that in the great majority of eggs

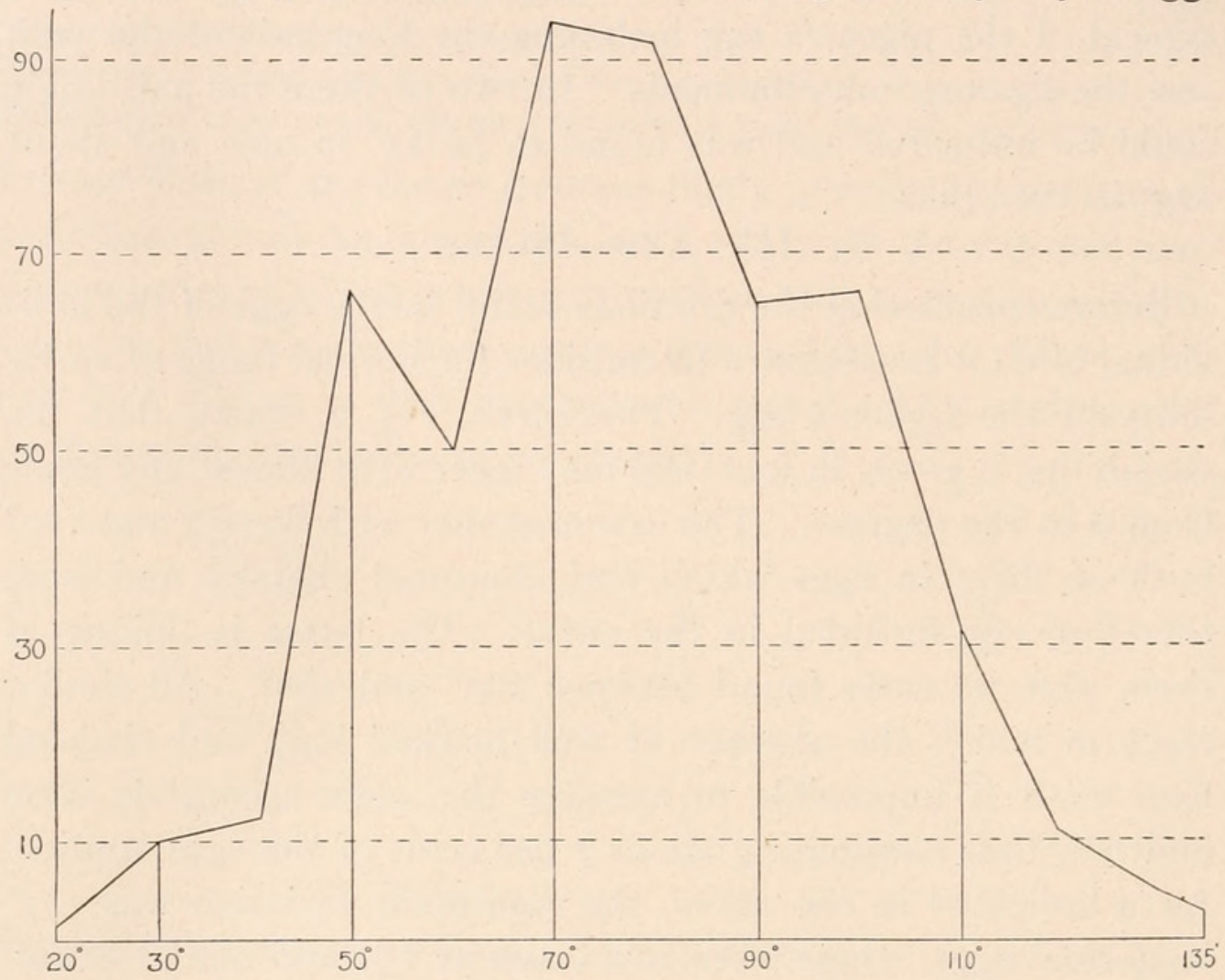

FIG. 2. Curve of variability in axis angles plotted from observations on 506 eggs from 90 different birds. The angles could be measured accurately to $5^{\circ}$. The eggs were grouped in $10^{\circ}$ classes and the number of cases in each class plotted as ordinates, the angles as abscissæ. The resemblance to a symmetrical curve of normal variability is apparent.

the head of the embryo lies in the second octant of the (animal) polar hemisphere.

\section{The Axis Angles of Individual Birds.}

My previously published data indicated that the eggs of a given bird show less variation in axis angles than do the eggs of different birds. The following birds were studied for four years, certain of their young mated and their eggs likewise observed. All the birds were the mongrel "homers" of the dealers. The original pairs were given me by Professor Whitman in I9Io. They had the freedom of a large attic room where they were free from disturbance, could choose their mates, build their nests and keep comparatively happy throughout the year. At the time I thought there might be some relation between sex 
and axis angle variation so in view of Professor Whitman's results the layings were not forced (see Riddle, I9I4). When the eggs were removed dummies were left in their places for about two weeks until the birds recognized the deceit or the futility of further incubation and made preparations for another laying. From time to time each pair was permitted to hatch and rear young. Under these conditions the average number of clutches per year was I6, a figure which has been considerably lowered by inclusion of the records of the old birds at the end of their active laying period. The spring was the most prolific season, the autumn the least so, as Pearl and Surface (I9I I) observed for the hen.

The angles were measured as described in I9I2. As some pigeon eggs show little difference between the two ends of the shell the position of the air space was always noted; its end of the shell is readily seen when the egg is placed in the salt solution since it floats up higher than the other. The blunt or air space end of the shell was held to the left, the other end removed with forceps and the contents drawn out. Thus any possible confusion between the two chalazæ was avoided. Except during the first year the eggs were left under the birds for two to three and one half days. As pigeons are usually very lax about incubating until the second egg has been laid the embryos varied from the five to the twenty somite stages. During this period the embryonic axis can be accurately observed and there is normally not enough yolk digestion or absorption of albumen to interfere with the identification of the long axis of the yolk.

Pigeon No. 3.- This was an old bird at the outset to judge from her subsequent activity. The first egg was laid March I6, I9I0, the last January I4, I9I2; ten weeks later she was killed and a normal resting ovary found. During these 22 months she laid 29 clutches without a single abnormal or infertile egg.

TAble J. (Pigeon No. 3.)

\begin{tabular}{|c|c|c|c|c|c|c|c|c|}
\hline Year. & $\begin{array}{l}\text { Normal } \\
\text { Eggs. }\end{array}$ & $\begin{array}{l}\text { Inver- } \\
\text { sions. }\end{array}$ & $\begin{array}{l}\text { Only } \\
\text { One } \\
\text { Egg in } \\
\text { Clutch. }\end{array}$ & $\begin{array}{c}\text { Infertile } \\
\text { Eggs. }\end{array}$ & $\begin{array}{c}\text { Abnor- } \\
\text { mal Em- } \\
\text { bryo. }\end{array}$ & $\begin{array}{l}\text { Eggs } \\
\text { Incu- } \\
\text { bated. }\end{array}$ & $\begin{array}{l}\text { Eggs } \\
\text { Lost. }\end{array}$ & Totals. \\
\hline I $\ldots \ldots \ldots \ldots \ldots$ & 25 & o & o & o & o & IO & I & 36 \\
\hline II $\ldots \ldots \ldots \ldots \ldots$ & $2 \mathrm{I}$ & o & I & o & o & 2 & o & 23 \\
\hline $\begin{array}{l}\text { Entire period of ac- } \\
\text { tivity I yr. Io mos.. }\end{array}$ & 46 & 0 & I & 0 & 0 & I 2 & I & 59 \\
\hline
\end{tabular}


All of the twelve eggs that were incubated to hatching produced normal young.

The only irregularity during almost two years was the laying of one clutch with a single egg. This is usually due to the failure of the first or second egg to enter the oviduct at ovulation or to its escape soon after. More rarely only a single ovum matures at a time.

The range of variability (Fig. 3,3 ) is striking as it ranges from 90 to I 30 degrees, whereas it is uncommon in the pigeon to find the angle greater than 90 degrees. The actual variability is small, and while this might be attributed to the small number of cases I am inclined to think the small number of extreme variants is to be correllated with the exceptionally well marked long axis and the uniformly normal chalazæ. Clutch 395 may serve as an example of the size relations of the axes of the ovum:

First egg (primitive streak embryo) $21.8 \mathrm{~mm}$. (long axis), $19.5 \mathrm{~mm}$. (transverse axis), $18.0 \mathrm{~mm}$. (polar axis).

Second egg (Io somites) $20.7 \mathrm{~mm}$. (long axis), I7.6 mm. (transverse axis), I8.0 mm. (polar axis).

We have in this case then a clue to the amount of variability which we must expect in eggs of a single bird where the ovum is normal and there are no irregularities in the functioning of the oviduct. That is to say, in this case the variations due to imperfect orientation in the oviduct and errors of observation due to abnormal chalazæ have been practically eliminated.

Pigeon No. 4.- This bird and her mate had recently paired when first observed. The first egg was laid January 4, I9I0. After sixteen clutches had been laid during thirteen months the male was killed by a Diener. Two months later no. 4 mated again and continued laying for the'next three years. A similar experiment was made purposely with no. 6 in order to see whether any difference could be observed between the eggs laid during the two matings. During the next two years no. 4 laid 29 clutches; and six during her last year; none of these last could have hatched as the table shows. She was killed March 2I, I9I4, when an abnormal egg was found in the "uterus," although ovary and oviduct appeared normal. The abnormality in the last year may have been due to the sperm although the male was apparantly normal and younger than his mate. 
Table II. (Pigeon No. 4.)

\begin{tabular}{|c|c|c|c|c|c|c|c|c|}
\hline Year. & $\begin{array}{c}\text { Normal } \\
\text { Eggs. }\end{array}$ & $\begin{array}{l}\text { Inver- } \\
\text { sions. }\end{array}$ & $\begin{array}{l}\text { Only One } \\
\text { Egg in } \\
\text { Clutch. }\end{array}$ & $\begin{array}{c}\text { Infertile } \\
\text { Eggs. }\end{array}$ & $\begin{array}{l}\text { Abnormal } \\
\text { Embryo. }\end{array}$ & $\begin{array}{c}\text { Incubated } \\
\text { Eggs. }\end{array}$ & $\begin{array}{l}\text { Eggs } \\
\text { Lost. }\end{array}$ & Totals. \\
\hline $\begin{array}{l}\text { I } \ldots \ldots \\
\text { II } \ldots \ldots \\
\text { III } \ldots \ldots \\
\text { IV } \ldots \ldots\end{array}$ & $\begin{array}{r}27 \\
\text { I } 5 \\
27 \\
0\end{array}$ & $\begin{array}{l}0 \\
\text { I } \\
\text { I } \\
\text { O }\end{array}$ & $\begin{array}{l}\text { I } \\
2 \\
4 \\
\text { I }\end{array}$ & $\begin{array}{l}\mathrm{I} \\
2 \\
\mathrm{I} \\
4\end{array}$ & $\begin{array}{l}2 \\
0 \\
3 \\
\mathrm{I}\end{array}$ & $\begin{array}{l}2 \\
8 \\
3 \\
0\end{array}$ & $\begin{array}{l}\text { I } \\
2 \\
0 \\
0\end{array}$ & $\begin{array}{r}32 \\
27 \\
29 \\
6\end{array}$ \\
\hline 4 years .. & 69 & 2 & 8 & 8 & 6 & I3 & 3 & 94 \\
\hline
\end{tabular}

This record doubtless includes the bird's entire period of activity. The falling off during the second year was due to the period between matings (the active months of February and March) and the hatching of four clutches later in the spring. As it was she laid 5 I clutches in the course of four years; I2 per cent. of the eggs were abnormal but most of these latter were laid during the last year.

The curve of variability (Fig. 3,4 ), has a single mode when $10^{\circ}$ classes are used but with five degree classes there is one mode at $70^{\circ}$ another at $85^{\circ}$. There is a total variation of $53^{\circ}$ from $5^{2}$ to $105^{\circ}$. 72 per cent. of the eggs measured fall between 65 and $85^{\circ}$. Of the twelve eggs which diverged most widely from the mean 9 showed irregularities in the chalazæ, the others were quite typical. One egg which showed an angle of $35^{\circ}$, twenty degrees lower than any other egg of this bird, was not included in the data plotted, as the long axis was obliterated by yolk digestion. Another egg which showed no well defined long axis had an angle near the other extreme of variation, namely $95^{\circ}$. The long axis was distinct in all the other eggs of no. 4, as may be seen from two examples:

Egg 399 (I I somites) 2I mm. (long axis), $19.0 \mathrm{~mm}$. (transverse axis), $19.0 \mathrm{~mm}$. (polar axis).

Egg 479 (primitive streak) $22.0 \mathrm{~mm}$., $19.4 \mathrm{~mm}$. (transverse axis), $18.0 \mathrm{~mm}$. (polar axis).

Two curves plotted from the eggs laid during the first and second matings are almost identical and so this case affords no evidence that the male has any effect upon the relation of embryo to principal egg axis.

The records of the remaining three pairs are more complete as they were the offspring of the above pairs. Their relationships are as follows: 

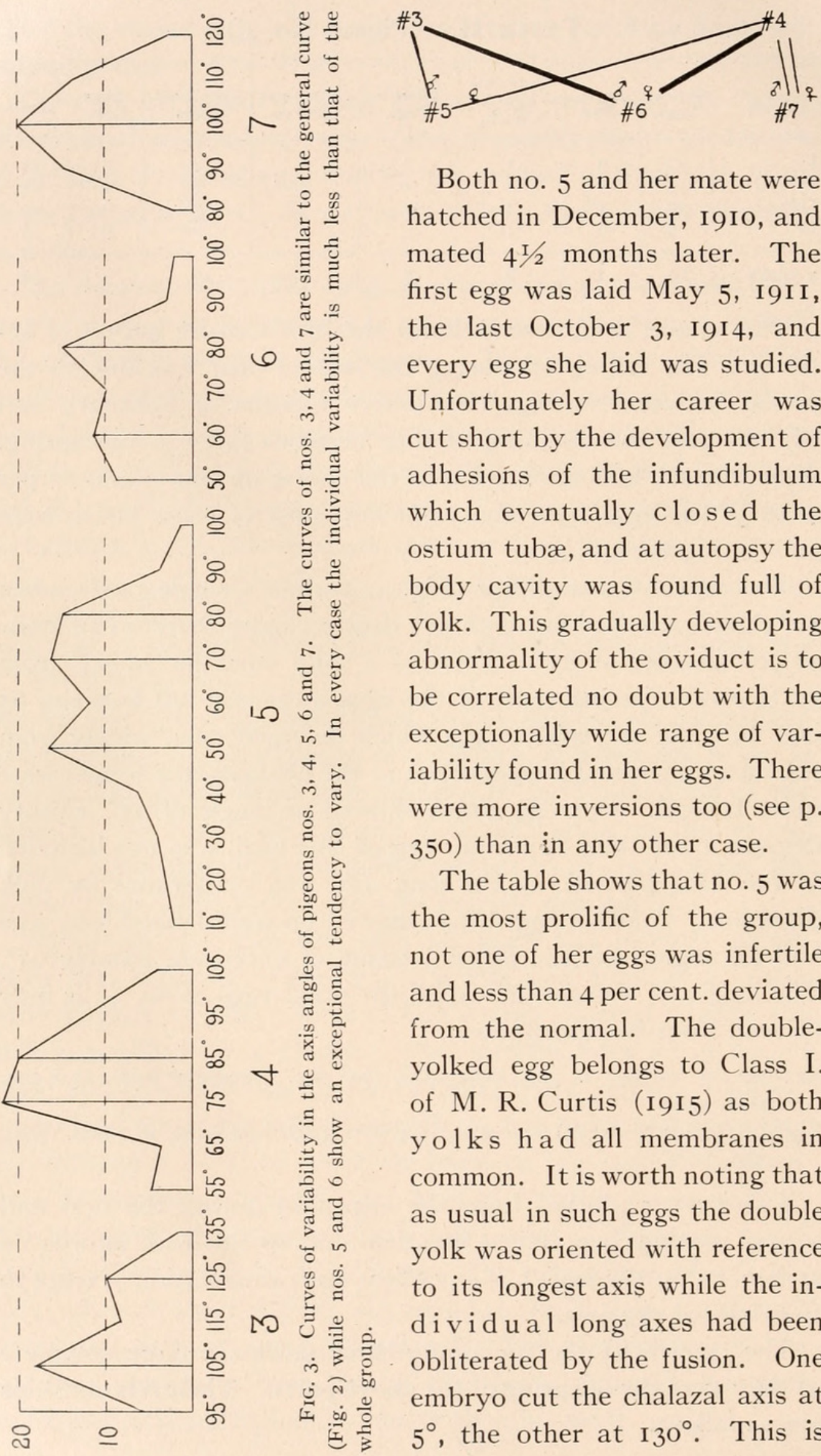

Both no. 5 and her mate were hatched in December, I9Io, and mated $4 \frac{1}{2}$ months later. The first egg was laid May 5, I9II, the last October 3, I9I4, and every egg she laid was studied. Unfortunately her career was cut short by the development of adhesions of the infundibulum which eventually closed the ostium tubæ, and at autopsy the body cavity was found full of yolk. This gradually developing abnormality of the oviduct is to be correlated no doubt with the exceptionally wide range of variability found in her eggs. There were more inversions too (see p. $350)$ than in any other case.

The table shows that no. 5 was the most prolific of the group, not one of her eggs was infertile and less than 4 per cent. deviated from the normal. The doubleyolked egg belongs to Class I. of M. R. Curtis (1915) as both yolks had all membranes in common. It is worth noting that as usual in such eggs the double yolk was oriented with reference to its longest axis while the individual long axes had been obliterated by the fusion. One embryo cut the chalazal axis at $5^{\circ}$, the other at $130^{\circ}$. This is 
Table III. (Pigeon No. 5.)

\begin{tabular}{|c|c|c|c|c|c|c|c|c|}
\hline Year. & $\begin{array}{c}\text { Normal } \\
\text { Eggs. }\end{array}$ & $\begin{array}{l}\text { Inver- } \\
\text { sions. }\end{array}$ & $\begin{array}{l}\text { Only } \\
\text { One } \\
\text { Egg in } \\
\text { Clutch. }\end{array}$ & $\begin{array}{c}\text { Infertile } \\
\text { Eggs. }\end{array}$ & $\begin{array}{c}\text { Abnormal } \\
\text { Eggs. }\end{array}$ & $\begin{array}{l}\text { Eggs } \\
\text { Incu- } \\
\text { bated. }\end{array}$ & $\begin{array}{l}\text { Eggs } \\
\text { Lost. }\end{array}$ & Totals. \\
\hline $\mathrm{I} \ldots \ldots \ldots \ldots$ & 32 & 0 & 2 & o & I & 5 & 5 & 42 \\
\hline II $\ldots \ldots \ldots$ & 29 & 2 & o & 0 & $\begin{array}{l}\text { I (double- } \\
\text { yolked egg) }\end{array}$ & 4 & o & 32 \\
\hline \multirow{2}{*}{$\begin{array}{l}\text { Last five } \\
\text { months...... }\end{array}$} & I9 & 3 & I & 0 & 2 & 3 & I & $2 \mathrm{I}$ \\
\hline & 7 & I & I & 0 & 0 & 0 & 0 & 7 \\
\hline 3 yrs. 5 mos... & 87 & 6 & 4 & 0 & 4 & I 2 & 6 & 102 \\
\hline
\end{tabular}

further evidence that extremes of variation in the axis angles are due to the failure of an ovum to orient itself in the oviduct with reference to its long axis. The nine extreme variants of this bird showed irregularities in the development of the chalazæ or other abnormalities. The long axis was well marked in all but three eggs. Clutch $6 \mathrm{I} I$ is typical;

First egg (7 somites ) $21.3 \mathrm{~mm}$. (long axis) $19.5 \mathrm{~mm}$. (transverse axis), I9.0 mm. (polar axis).

Second egg (4 somites) 2 I.0 mm. (long axis) $19.8 \mathrm{~mm}$. (transverse axis), I8.0 $\mathrm{mm}$. (polar axis).

Although only three of this bird's eggs had abnormal embryos and all twelve eggs that were incubated hatched, yet her eggs showed the greatest variability (Fig. 3, 5), a fact which, as has been said, is to be correlated with the abnormal oviduct. One extreme observed was $5^{\circ}$, this was a very abnormal egg as the chalazæ were not attached to the yolk at all but to the outside of the dense albumen. The greatest variation was $84^{\circ}$ among the normal eggs.

Pigeon No. 6.- This bird was hatched January 30, I9I I, but did not mate until eight months later. The first egg was laid October 29, I9II. Since there were 7 infertile eggs in the next I 3 clutches, the male was killed and five months later she mated again with the bird indicated on page 343 . In the following two years and two months 24 clutches were laid. The observations had to be discontinued before she ceased to lay, but as she was four years old at the time and had begun to lay numerous abnormal and infertile eggs this record represents practically all her reproductive activity. The high percentage of infertile eggs during the first year was undoubtedly due to her first mate; nevertheless her layings were very irregular and could never be predicted. The curve (Fig. 3, 6 ) shows that the axis angles varied 
TABle IV. (Pigeon No. 6.)

\begin{tabular}{|c|c|c|c|c|c|c|c|c|}
\hline Year. & $\begin{array}{c}\text { Normal } \\
\text { Eggs. }\end{array}$ & $\begin{array}{l}\text { Inver- } \\
\text { sions. }\end{array}$ & $\begin{array}{c}\text { But One } \\
\text { Egg in } \\
\text { Clutch. }\end{array}$ & $\begin{array}{c}\text { Infertile } \\
\text { Eggs. }\end{array}$ & $\begin{array}{c}\text { Abnormal } \\
\text { Eggs. }\end{array}$ & $\begin{array}{l}\text { Incu- } \\
\text { bated } \\
\text { Eggs. }\end{array}$ & $\begin{array}{l}\text { Eggs } \\
\text { Lost. }\end{array}$ & Totals. \\
\hline $\begin{array}{l}\text { I } \ldots \ldots \cdots \\
\text { II } \ldots \ldots \cdots \\
\text { III } \ldots \ldots \ldots\end{array}$ & $\begin{array}{l}22 \\
\text { I } 2 \\
2 \mathrm{I}\end{array}$ & $\begin{array}{l}0 \\
0 \\
0\end{array}$ & $\begin{array}{l}0 \\
I \\
2\end{array}$ & $\begin{array}{l}7 \\
2 \\
4\end{array}$ & $\begin{array}{c}0 \\
0 \\
3 \text { (one was } \\
\text { yolkless) }\end{array}$ & $\begin{array}{l}0 \\
8 \\
\text { I }\end{array}$ & $\begin{array}{l}I \\
0 \\
2\end{array}$ & $\begin{array}{l}30 \\
19 \\
30\end{array}$ \\
\hline 3 years 5 mos. & 53 & 0 & 3 & I3 & 3 & 9 & 3 & 79 \\
\hline
\end{tabular}

in a typical manner, the extremes in normal eggs being $43^{\circ}$ and $98^{\circ}$. The most extreme variations were here clearly due to imperfect orientation in the oviduct. Thus two eggs which had no long axis showed angles of $105^{\circ}$ and $180^{\circ}$ respectively. Most of her eggs had a well-defined long axis; e. g., no. 497, 21.9 mm. (long axis), I $8.0 \mathrm{~mm}$. (transverse axis), $17.5 \mathrm{~mm}$. (polar axis). There was no difference to be found in the angles of the eggs laid during the first and second matings.

Pigeon No. 7.- The egg from which this bird was hatched was laid only five days after the last egg of the previous clutch. As it is very rare for a pigeon to lay a second clutch in less than eight days after a first, it seemed possible that the egg might have been laid in no. 4's nest by another bird. However all the active females in the flock had laid within seven days of this date so it seems unnecessary to speculate on the possibility of the parent birds having failed to guard their nest long enough for another bird to lay in it. No. 7 was hatched April 20, I9I2, her mate the middle of the following August and they mated in November. The first egg was laid December 2, I9I2. The 34 clutches laid during the following two and a quarter years when the work was stopped do not nearly represent the whole active period of this bird.

Table V. (Pigeon No. 7.)

\begin{tabular}{|c|c|c|c|c|c|c|c|c|}
\hline Year. & $\begin{array}{c}\text { Normal } \\
\text { Eggs. }\end{array}$ & $\begin{array}{l}\text { Inver- } \\
\text { sions. }\end{array}$ & $\begin{array}{l}\text { But One } \\
\text { Egg in } \\
\text { Clutch. }\end{array}$ & $\begin{array}{c}\text { Infertile } \\
\text { Eggs. }\end{array}$ & Abnormal Eggs. & $\begin{array}{l}\text { Incu- } \\
\text { bated } \\
\text { Eggs. }\end{array}$ & $\begin{array}{l}\text { Eggs } \\
\text { Lost. }\end{array}$ & $\begin{array}{l}\text { Totals } \\
\text { for } \\
\text { Year. }\end{array}$ \\
\hline $\begin{array}{l}\text { I } \ldots \ldots \ldots \\
\text { II . . . . . } \\
\text { mont three } \\
\text { months..... }\end{array}$ & $\begin{array}{l}20 \\
26\end{array}$ & $\begin{array}{l}0 \\
0\end{array}$ & $\begin{array}{l}0 \\
0\end{array}$ & $\begin{array}{l}\text { I } \\
\text { I }\end{array}$ & $\begin{array}{c}\text { I } \\
\text { I (double- } \\
\text { yolked egg) } \\
\text { I }\end{array}$ & $\begin{array}{l}2 \\
5\end{array}$ & $\begin{array}{l}2 \\
\mathrm{I}\end{array}$ & $\begin{array}{l}26 \\
32\end{array}$ \\
\hline 2 yrs. 3 mos.. & 56 & o & 0 & 2 & 3 & 7 & 3 & 68 \\
\hline
\end{tabular}


The table shows few peculiarities. The range of variability was low (from 75 to $\operatorname{II} 7^{\circ}$ ). There were five eggs which had no well-marked long axis; three of them had extreme angles $\left(70^{\circ}\right.$, II $7^{\circ}$ and $\left.124^{\circ}\right)$, the other two from a single clutch, were $95^{\circ}$ and $96^{\circ}$. In this case (clutch 629) the ova measured as follows:

First egg $2 \mathrm{I} .2 \mathrm{~mm}$. (chalazal axis) $2 \mathrm{I} .2 \mathrm{~mm}$. (transverse axis) $\mathrm{I} 9.3 \mathrm{~mm}$. (polar axis). Second egg $19.2 \mathrm{~mm}$. (chalazal axis) $19.0 \mathrm{~mm}$. (transverse axis) $19.0 \mathrm{~mm}$. (polar axis).

\section{Discussion.}

A. Variability of the Axis Angles.-The data presented here are the most complete that have been gathered with reference to the axis angles of any bird's egg and they show that while the actual angle may vary considerably, the relation between the head of the embryo and the principal egg axis is very constant. What I have called "inversions" (see p. 349) occur in less than I per cent. of the cases. The embryo may lie in almost any position compatible with the general relation between the two axes. If we omit eggs that were not normal as to embryo or chalazæ (circ. Io per cent. of all), and include only those which could be measured accurately, the extreme axis angles are 8 and $\mathrm{I} 35^{\circ}$. If we compare this maximum with the maximum found for any single bird, namely, $127^{\circ}$ as compared with $86^{\circ}$, it is obvious that a given bird's eggs will show less variability than the eggs from a flock. The difference between the two is not fully appreciated until we realize that the maximum variability in the other four birds of the group studied was 40,42 , 53 and $55^{\circ}$ respectively; the average maximum variability then for a single bird's eggs is about two thirds of the total variability observed. We may predict that a given pigeon's eggs will show the embryo lying in a quadrant the center of which is usually between 45 and $95^{\circ}$ according to the particular bird. In other words the embryonic axis will cut the principal egg axis at an angle which may vary $25^{\circ}$ on either side of a mean. The variation we find in an individual bird's eggs makes it clear that the axis angle is no mathematically constant one like the angles of a crystal. There are various mechanical factors operating during ovarian and oviducal stages which undoubtedly contribute to the variability of the axis angle. Thus it is easy to see how 
during the growth of the oöcyte the original long axis might be changed more or less, particularly during the final rapid growth period. The oöcyte is free to rotate within its follicle at this time and if it cannot hang down into the body cavity so that attached and animal poles coincide exactly, the long axis of the follicle may not coincide with the original long axis of the ovum. At this time the embryonic axis is already established and so the original relation between long and embryonic axes may be changed (cf. Bartelmez, I9I2, p. 288).

The fact that all the most extreme variations were found in eggs with irregular chalazæ or poorly defined long axes makes it certain that difficulties of orientation in the oviduct at ovulation are important factors in axis angle variability. Further, if the chalazæ are not normally attached it is impossible to make accurate measurements. Eleven out of sixteen eggs which had no long axis or very irregular chalazæ were extreme variants for the bird that laid them. It is of course obvious that these factors may partly neutralize each other. This will not explain all the variations observed. We must assume a certain amount of spontaneous variability in the eggs of an ovary.

The first compilations seemed to show that there are always two modes in the curve of individual variation. These appear in Fig. 3, 3, 5 and 6 , and the same grouping about two modes can also be seen in the case of the eggs of no. 4. It was natural to expect that this might be correlated with the heterozygous nature of the bird's egg (see Riddle, I9I2, I9I4). That is to say, the larger, female-producing, eggs might vary about one mean, the smaller, male-producing, eggs about the other. The data from the 58 young hatched in the course of the study gave no evidence that the first egg was more frequently male-producing and Dr. Riddle tells me that this condition is found only in pure races of pigeons. Since also the size and weight of incubated yolks varies greatly from the absorption of albumen this possibility could not be tested out.

It is however a matter of great practical importance to see what the chances are that the first and second eggs will have about the same angles. In collecting early stages we usually determine the stage of the second egg from the time of laying of 
the first and so the first is available for a measurement of the axis angle. The following table shows the results.

\begin{tabular}{|c|c|}
\hline $\begin{array}{c}\text { Normal Range of } \\
\text { Variability, }\end{array}$ & $\begin{array}{c}\text { Percentage of Clutches in which } \\
\text { Both Eggs have the Same } \\
\text { Axis Angle. }\end{array}$ \\
\hline No. $3,40^{\circ}$ (from 90 to $\left.130^{\circ}\right)$ & $\ldots \ldots 45$ per cent. \\
\hline No. $4,53^{\circ}$ (from 52 to $\left.105^{\circ}\right)$ & $\ldots \ldots 46$ per cent. \\
\hline No. $5,84^{\circ}$ (from 8 to $\left.92^{\circ}\right)$ & ..30 per cent. \\
\hline No. $6,55^{\circ}$ (from 43 to $\left.98^{\circ}\right)$. & $\ldots 45$ per cent. \\
\hline No. $7,42^{\circ}$ (from 75 to II $\left.7^{\circ}\right)$ & $\ldots .56$ per cent. \\
\hline
\end{tabular}

The average of these is 43 per cent. of coincidence, but if the very irregular no. 5 be omitted it is $5^{8}$ per cent.

It should be said further that there is no evidence that the eggs of a mother and daughter tend to resemble each other as to axis angles nor that there is any noticeable difference in the eggs of a bird during a first and second mating or during the early or later parts of her laying period.

We may say in conclusion that two sets of factors contribute toward extreme variation; irregularities in the laying down of the yolk during the final rapid growth period and irregularities in the functioning of the oviduct during the passage of the ovum. Aside from this we must expect normal spontaneous variation to the extent of at least 20 degrees on either side of a mean. This estimate of $40^{\circ}$ as the probable maximum spontaneous variation is based upon the records of no. 3 the eggs of which showed no signs of ovarian or oviducal irregularities. Accordingly, if we wish to determine the embryonic axis at a stage when it is not clearly differentiated morphologically, we can distinguish the cephalic from the caudal end of blastodisc or blastoderm in 99 out of Ioo cases. The axis angle however, can only be approximated. If the utmost possible accuracy is desired it is necessary to first measure a series of clutches, approximate the mode, eliminate such birds as show great variability, and use this mean angle. It is not likely to be more than $20^{\circ}$ wrong in any given egg. Nevertheless, the possibility of even greater variation must be considered in the interpretation of the results.

B. Inversions.-By inversions I mean those instances in which the head of the embryo is directed toward the observer when the egg is held in the usual manner (Figs. I and 4). Von Baer, (I828, 
p. I2) as he was the first to discuss axis angles was the first to record an inversion. He observed only one and suggested that it might have resulted from the cracking of the shell before incubation. It is evident from this that he did not appreciate the fundamental nature of the relation between embryo and principal egg axis. Subsequent workers, perhaps on this hint of v. Baer's, have presented evidence that the axis angle may be changed by experimental means. Thus Blanc (I892), Féré (I897 and later), Ferret et Weber (1904) and others have reported not only an increase in the number of extreme variations but also an increase in the number of inversions after poisoning the embryo or after interference with the secondary envelopes. While it is possible that an injured embryo may grow irregularly and so change the original direction of its axis (Féré, I900) it is highly improbable that it could become inverted. Most of these workers have not adequately determined the normal range of variability of their material. As has been said, the variability may in certain cases be much greater in the hen than in the pigeon. Professor A. P. Mathews tells me that as a student he planned similar experiments but abandoned them when he realized the extent of the normal variation in the hen's egg.

It is interesting to note in this connection that the earlier editions of Foster and Balfour's text-book gave the relations here termed "inversions" as the normal ones for the hen. As Balfour wrote this section of the book it may have been based upon his own observations or it may have merely been an accidental error. Dalton (I88I) reported I2 hen's eggs inverted out of Ioo while Duval (I884) found only one among I66, Rabaud (1908) I 2 in 98 and the writer 33 in Ioo. For the pigeon on the other hand I reported (I9I2, p. 30I), four cases among over 600 observations by Drs. Blount, Patterson and myself. The present study has thrown some new light on the question.

Inversions are very rare in pigeon eggs. I have studied eggs from about 90 pigeons; while many of them came from the five birds mentioned above, between two and twenty have been obtained from each of the others. Among all these only two birds, no. 4 and no. 5 laid inverted eggs. No. 4 laid two among 94 , no. 5 six among I02 eggs. In pigeon no. 5 the axis angles was 
exceptionally variable. The other three birds laying an aggregate of 204 eggs had no inversions. This gives a clue to the reason for the great difference in the number of cases reported for the hen. We are again dealing with a matter of individual variation. It is manifest that we should exclude from our studies involving axis angles all birds which show a tendency to vary over $25^{\circ}$ from a mean.

How are we to interpret the phenomenon when it does occur? Is it due to an inversion of relations in the ovary or is it more or less accidental? It is always possible that a normal ovum may be unable to orient itself with reference to gravity before ovulation owing to pressure from neighboring ova, adhesions of the

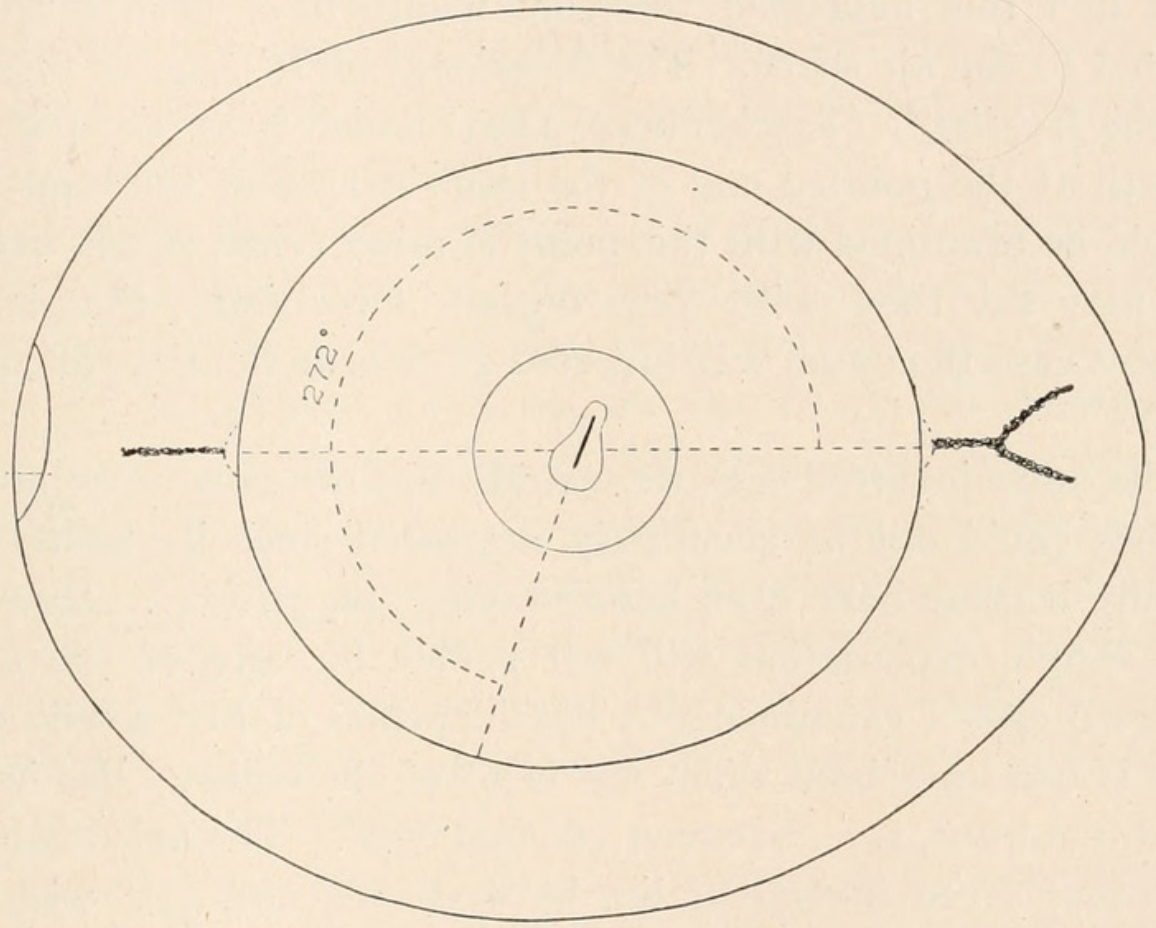

FIG. 4. A diagrammatic polar view of a pigeon's egg showing an "inverted" embryo. This type of inversion can be explained (egg $479^{\prime}$ of no. 4). In this particular case the inversion was very probably due to the fact that the end of the long axis of the yolk which should have entered the oviduct first, entered last.

oviduct, etc., and so the end of the long axis which should have entered first enters last. It may also have fallen in to the cœlom at first and have subsequently entered the duct inverted. Since we have complete records of no. 4 and no. 5 , the only birds I ever had which laid inverted eggs there is a basis for something more than speculation. When I opened egg $479^{\prime}$ of no. 4 and 
found the relations shown in Fig. 4 it was clear that if the egg were turned about the polar axis through $180^{\circ}$ we would have the usual axis angle for this bird, as 75 per cent. of her eggs had angles between 65 and $85^{\circ}$. Now if the normal orientation of the oöcyte had been accidentally inverted the latebra should be found nearer the cloacal chalaza than the other (vide p. 334 supra). It was poached, cut through the long and polar axes and the latebra was found I. $3 \mathrm{~mm}$. nearer the cloacal end of the long axis (toward the pointed end of shell) the reverse of the usual condition. It is always possible that the egg was not inverted until after it had entered the "uterus" but before the shell had been laid down (cf. Taschenberg, I 894, p. 308), but I am inclined to think that had this happened the yolk would have been normally related to the air space. The occasional birds' eggs as those of Corvus frugilegus (Taschenberg, I 894) which have the pigment wreath at the pointed end of the shell instead of the blunt end should be examined with this point in mind (vide, p. 332 supra). We may say then, with some degree of certainty, that in the present case the ovum was inverted at or near the time of ovulation.

The other inverted eggs were studied in the same way but the latebra could not be accurately measured since its boundaries usually become hazy even before laying (see p. 334). However this simple explanation will not suffice for any of the other inverted eggs I examined. A consideration of Fig. 4 will show that it can only hold when the head of the embryo lies in the third quadrant, i.e., between $\mathrm{I} 80$ and $270^{\circ}$. The axis angles of the other seven inversions lies between 285 and $325^{\circ}$ with the head therefore in the fourth quadrant. If, in these cases, we are to get the relations of embryo and long axis characteristic of the bird we must turn the ovum through $\mathrm{I} 80^{\circ}$ about the long axis and view the embryo from the vegetal pole as if the yolk were transparent. Obviously this means a reversal of polarity. There is a period in oögenesis when this might happen but I do not see how it could be demonstrated. At the beginning of my "period of differentiation" namely, (I9I2, p. 286), when the nucleus is nearer the center of the oöcyte than at any other time, it is possible especially in oöcytes with the animal pole nearer the 
periphery of the ovary, that the yolk might be so laid down that the nucleus would approach the original vegetal instead of the animal pole. Thus inversion would be accomplished. It should be noted also that three of the inverted eggs of no. 5 were the first eggs of three successive clutches and a fourth was laid soon after, all of them dating from the last six months before the ostium was closed by adhesions.

It is clear from these data that inversions are exceedingly rare in pigeons' eggs, and that only certain individuals ever lay such eggs. There are two types: those which are due to an inversion of the long axis of the ovum at ovulation and those which may be explained by assuming an inversion of the polarity of the oöcyte. It might be expected in such a case that one should find situs inversus viserum but this was not noted in the one instance in which the embryo was far enough developed to reveal it (cf. Conklin, I903).

C. Variations in the Chalaze. - The most accurate and convenient method of measuring the axis angle in an egg is to determine the relation between the chalazal and embryonic axes. Patterson (I909) was, I believe, the first to use the chalazæ for this purpose and I found it by far the most satisfactory method. It is important therefore, to see exactly how variable the chalazæ are and especially how frequently the chalazal axis deviates from the long axis of the ovum which determined it as well as other characters of the principal egg axis. A similar series of observations should be made on the hen's egg where there seems to be much more irregularity.

Typically one finds the chalazæ attached to the chalaziferous albumen at the ends of the long axis of the ovum. As the animal pole flattens out more and more during incubation the points of attachment seem to approach the animal pole, still remaining in the greatest circle of the elliptical ovum. It is rare to find this condition in the pigeon during the first two days of incubation. One often finds a cap or button of clear chalaziferous albumen at the point where each chalaza is attached. Usually when the infundibular (i.e., blunt end) chalaza lies free in the albumen or has become invisible this button marks the corresponding end of the chalazal axis. Again there are eggs which show both 
chalazæ unattached and in these there is no chalazal axis. The two chalazæ are frequently unequal in size or form, as was said above (p. 327). Thus only the cloacal chalaza may be forked at the end, or it may be merely longer or stouter than the infundibular one. On the other hand, the two may be indistinguishable. The following table shows the absolute and relative frequencies with which these were encountered and it gives also the frequencies of various kinds of abnormal eggs.

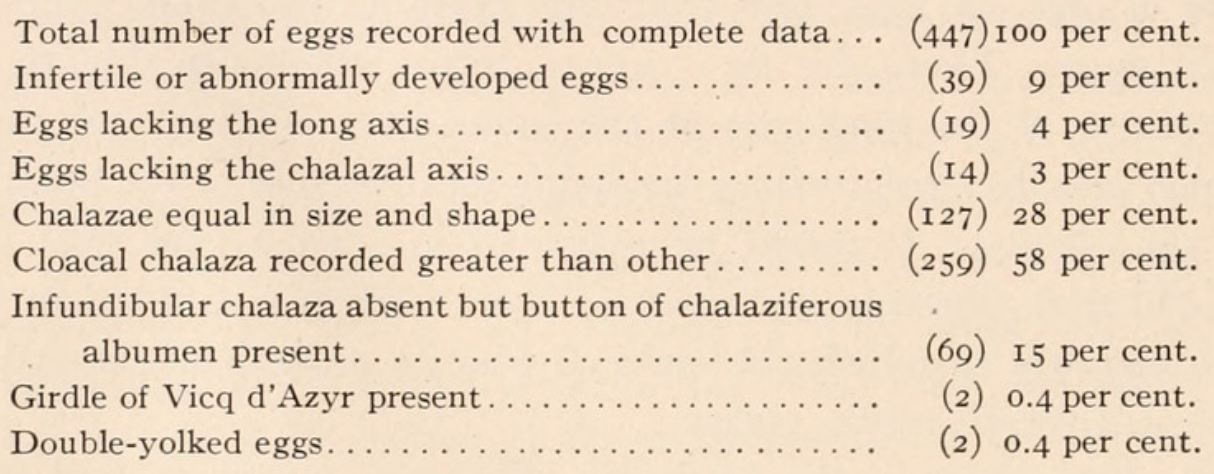

It should be said that of the I9 cases which had no long axis 5 were either infertile or had abnormal embryos. This was true of 3 which lacked the chalazal axis. On the other hand, irregular chalazæ are much more frequent. Patterson (1909) reported 8 per cent. such eggs, including those which lacked one chalaza. If we make a similar category in the present records, including those eggs which have only a button at the infundibular end of the long axis and those with accessory and unattached chalazæ we get 9I cases (20 per cent.). I have records of only two eggs which had both long and chalazal axes abnormal; approximate measurements of the axis angle can be made in 98 per cent. of normal pigeons' eggs and accurate measurements can be made in 88 per cent. of cases. When the long and chalazal axes do not coincide, as occurs in 2 per cent. of the eggs, they may diverge from 4 to $20^{\circ}$, very rarely more. Most of these were otherwise normal and it should be borne in mind that the same is true of most eggs which lack long or chalazal axes. This emphasizes the fact that this relation is an effect, not a cause; it is simply the morphological expression of the presence of certain axes of bilaterality. The embryo may develop normally whether this expression is perfect or not.

We may say then, that in the pigeon's egg the chalazæ vary 
considerably, although extreme irregularities are rare (3 per cent.). Since the two chalazæ were indistinguishable in only 28 per cent. of cases we may say that in the majority of eggs more albumen is secreted below the ovum than above it when it first enters the duct and consequently the cloacal (pointed end) chalaza is frequently larger than the other. Unfortunately I have recorded only $\mathrm{I} 4$ of the instances when this was found to be the case in early oviducal eggs.

\section{General Conclusions.}

I. The older literature on the bird's egg has been grossly neglected by recent students of this subject.

2. The bilaterality of this egg finds expression in two axes of bilateral symmetry: the embryonic axis and the principal egg axis which is defined for the most part by characters of the secondary egg envelopes.

3. These axes are definitely related to each other in such a way that the right side of the embryo is nearer one of the ends of the principal axis than the other.

4. This holds for the eggs of all the species that have been examined with this relation in mind: viz., the domestic fowl, the common pigeon, the emu, the duck and perhaps the sparrow.

5. The actual angle between the two axes (axis angle) is subject to great variation.

6. Conclusions from observations on the pigeon's egg.

(a) The axis angle was found to vary almost $180^{\circ}$ but 85 per cent. of the cases fell between 45 and $90^{\circ}$.

(b) Eggs obtained from a single bird vary much less, the maximum variation being from 32 to 68 per cent. of that found in eggs from the entire flock.

(c) Extreme variations of the axis angle are probably due to imperfect orientation of the ovum in the oviduct, to abnormalities in its action or to irregularities during the final growth period of the oöcyte. Such eggs usually show irregularities either of long axis or chalazæ.

(d) The angle in normal eggs of a given bird, while usually restricted to a range of $45^{\circ}$ is apparently determined within this range by the laws of chance during oögenesis. 
(e) In about one half the clutches studied the angles of the first and second eggs agreed closely. This is a matter of great practical importance in the study of ovarian and oviducal eggs.

$(f)$ Inversions are due either to the reversal of the long axis of the ovum at about the time of ovulation or they may be due to the reversal of the polarity of the oöcyte early in oögenesis.

(g) The long axis could be identified in 96 per cent. of the eggs studied, the chalazal axis in 97 per cent. The two coincided in 98 per cent. of normal eggs.

(h) The chalazae were found abnormal in only 3 per cent. of cases but more or less atypical in 20 per cent. of cases.

(i) In $5^{8}$ per cent. of the eggs the cloacal (i.e., pointed end) chalaza was strikingly larger than the other.

I am indebted to the Librarians of the Surgeon General's library and of the Harvard Library for the loan of several of the older works mentioned and to Miss E. Dickenson of the University of Chicago Library for help in tracing many of the earlier references.

\section{BIBLIOGRAPHY.}

The titles marked with an * do not appear or are inaccurately cited in the bibliography of Keibel und Abraham's Normentafel or the corresponding work of Grosser und Tandler.

Aldrovanus, U.

I646 Opera Omnia Lib. I-III. Bononiæ, I646.

Aristotle (324-322 B.C.)

De generatione animalium. Translated by A. Platt. Oxford, I9Io.

v. Baer, C. E.

I828-'88 Ueber die Entwickelungsgeschichte der Thiere-Beobachtung und Reflexion. I. Theil, I828; II. Theil, no. I, I837; II. Theil, no. 2, I888 (Ed. L. Stieda). Leipzig.

\section{Barry, M.}

I838 Researches in embryology, Ist Series. Philosophical Transactions, p. 301. London.

Balfour, F. M.

See Foster \& Balfour.

Bartelmez, G. W.

1912 The Bilaterality of the Pigeon's Egg. Jour. Morph., Vol. 23, p. 269.

Berthold, A. A.

1829 Ueber die Bildung und den Nutzen der Hagel (Chalazæ) im Vogeley. Isis, I 829 , p. 404.

Blanc, L.

I8́92 Note sur l'influence de la lumière sur l'orientation de l'embryon dans l'œuf de poule. Compt. Rend. Soc. Biol., T. 44, p. 774. 


\section{Blount, Mary}

r909 The Early Development of the Pigeon's Egg with Especial Reference to Polyspermy and the Origin of the Periblast Nuclei. Jour. Morph., Vol. 20, p. I.

*Bonnet, C.

I762 Considérations sur les corps organisés. Genéve (from Collection complete des œuvres. T. VI., p. 4I2).

Conklin, E. G.

I903 The Cause of Inverse Symmetry. Anat. Anz., Bd. 23.

Coste, M.

I847 Histoire général et particulière du développement des corpes organisés. Paris.

Curtis, M. R.

I9r I An Accurate Method for Determining the Weight of the Parts of the Eggs of Birds. Maine Ag. Exp. Stat. Annual Report, I9I1, pp. 93-II2.

I9I4 Factors Influencing the Size, Shape and Physical Constitution of Eggs. Arch. f. Entwkm., Bd. 39, p. 217.

I9I5 The Relation of Simultaneous Ovulation to the Production of Double Yolked Eggs. Jour. Ag. Research, Vol. 3, p. 376.

Dalton, J. C.

I88 I The Position of the Embryo in the Fowl's Egg. Medical Record, v. 20, p. 589 .

Darest, C.

I89I Recherches sur la production artificielle des monstrosities. Ed. II., Paris.

*Dutrochet, $\mathbf{H}$.

I8r9 Histoire de l'oeuf des oiseaux avant la ponte. Jour. de Physique, Chem., Hist., Nat., etc., T. 88, p. I70. Review: Deut. Arch. Physiol., Bd. 6, p. 379 .

Duval, M.

r884 De la formation de blastoderme dans l'œuf des oiseaux. Ann. des Sc. nat. Zoöl., Ser. 6. T г8. p. I.

r889 Atlas d'Embryologie. Paris.

*Erdmann

I886 Briefliches über Eierlegen. Jour. f. Ornith., Bd. 34, p. 406.

Fabricius ab Aquapedente, Hier.

1625 De formatione ovi et pulli. (From opera omnia Anat. et Physiol., I738 ed., B. S. Albini.)

Féré, Chas.

r894 Note sur l'influence des enduits partiels sur l'incubation de l'œuf de poule. C. R. Soc. Biol., I894, p. 65.

I896 Note sur l'orientation et sur l'allure du développement de l'embryon de canard. C. R. Soc. Biol., I 896.

I897 Note sur le développement et la position de l'embryon du poulet dans les œufs a deux jaunes. C. R. Soc. Biol., I897, p. 858 .

I897 Note sur les changements de position et de forme du jaune de l'œuf de poule pendendant l'incubation. C. R. Soc. Biol., I897.

$\mathbf{9 0 0}$ Note sur la multiplicité des causes des variations de l'embryon du poulet. Jour. Anat. Physiol., Ann. 36, p. 2 I0. 


\section{Ferret et Weber}

r904 Influence de la piqûre des enveloppes secondaires de l'oeuf de poule sur l'orientation de l'embryon. Ar. zoöl. exp. gén., Sér. 4, T. 2. Notes et Revues, p. lx.

Foster, M., and Balfour, F. M.

I874 The elements of embryology. London.

Galeb, O.

I879 De l'oeuf dans la série animale. Paris.

Grosser, O., und Tandler, J

I909 Normentafel zur Entwicklungsgesichte des Kiebitzes (Vanellus cristatus). Jena.

Haller, Alb.

I758 Sur la formation du coeur dans le poulet. Lausanne.

Harper, E. H.

I904 The Fertilization and Early Development of the Pigeon's Egg. Am. Jour. Anat., Vol. 3, p. 349

Harvey, William

I65 I Exercitationes de generatione animalium. London.

Haswell, W. A.

r887 Observations on the Early Stages in the Development of the emu (Dromæus novæ hollandiæ). Proc. Linn. Soc. New South Wales, II. series, Vol. 2, p. 577 .

\section{Hertwig, O.}

I906 Handbuch der vergleichenden und experimentellen Entwicklungs-

His, W. geschichte der Wirbelteire. Bd. I, Jena.

I868 Untersuchungen über die erste Anlage des Wirbeltierleibes. Die erste Entwicklung des Hünchens im Ei. Leipzig.

Home, E.

I822 On the Changes the Egg Undergoes During Incubation. Phil. Trans., Vol. II2, p. 339. London.

*Jasse, J.

I886 Aus Bericht der Ornith. Ges., Jour. f. Ornith. Bd. 34 p. I24.

Jörg, J.

I8I5 Die wieblichen Zeugungsorgane und das Ei in den verschiedenen Thierklassen. Leipzig.

Keibel, F., und Abraham, $\mathrm{K}$.

I900 Normentafel zur Entwicklungsgesichte des Huhnes. Jena.

Kionka, H.

I894 Die Furchung des Hühnereies. Anat. Hefte, Bd. 3, p. 429.

Kölliker, A. v.

I86I Die Entwicklungsgeschichte des Menschen und der höheren Wirbelthiere. Leipzig.

*König-Warthausen, $\mathrm{R}$.

I885 Die Gestalt der Vogeleier und deren Monstrositäten.

*Kutter, $\mathbf{F}$.

r878 Betrachtung über Systematik und Oölogie vom Standpuncte der Selectionstheorie. II. Teil, Jour. f. Ornith., Bd. 26, p. 300.

r880 Bermerkungen über einige oölogische Streitfragen. Jour. f. Ornith., Bd. 28 , p. I57. 
Landois, H.

I877 Missbildungen bei Hühnereiern.

Langly, W.

I674 Observationes quædam de generatione animalium. Amsterdam.

Leuckart, $\mathbf{R}$.

I853 "Zeugung" in R. Wagner, Handwörterbuch der Physiologie.

Léveillé, J. B. F.

I799 Dissertion physiologique sur la formation des foetus dans les mammifères

Lillie, F. R

et dans les oiseaux. Jour. de Physique, Ann. 7 (de la Republique), p. 386.

I908 The Development of the Chick. New York.

Locy, Wm

I908 The Makers of Biology. New York.

Maitrejean, A

I722 Observations sur la formation du poulet. Paris.

Malpighi, $\mathbf{M}$

I672 De formatio pulli in ovo dissertatio.

I675 Anatome plantarum, cui subjungitur appendix iteratus et auctas ejusdem auctoris de ovo incubato observationes continens. From Opera Omnia, R. Scott, London, I686.

Marshall, A $\mathbf{M}$

I893 Vertebrate Embryology. London.

*Mayer, F J C.

r865 Ueber das Ei der Vögel und Reptilien. Nova Acta Acad. Nat. Curios. Dresden, Bd. 32.

Meckel, H. von Hemsbach

I85I Die Bildung der für die partielle Furchung bestimmte Eier der Vögel im Vergleich mit den Graafschen Follikel und die Decidua des Menschen. Zeit. f. Wiss. Zoöl., Bd. 3, p. 420.

Mertens, $\mathbf{N}$.

I830 Beiträge zur Kenntniss der Fetushüllen im Vogelei. Meckel's Ar. f. Anat. u. Physiol., I830.

M urray, J.

r826 On the temperature of the egg of the hen, in relation to its physiology. Edinb. Philosoph. Jour., no. 27.

* Nasse, $\mathrm{O}$.

I862 Die Schleimhaut der inneren weiblichen Geschlechtsteile im Wirbelthierreich. (Inaug. Diss.) Marburg.

Nathusius, W. v.

I868 Ueber die Hüllen welche den Dotter des Vogeleis umgeben. Zeit. f. Wiss. Zoöl., Bd. I8, p. 225.

I893 Die Entwicklung der Schale und Schalenhaut des Hühnereies im Oviduct. Ibid., Bd. 55 , p. 576 .

I885 Besteht eine ausnahmslose Regel über die Lage der Pole des Vogeleies im Uterus im Verhältnis zur Kloakenmündung? Zoöl. Anz., Bd. 8, p. 4I5.

I885 Ueber die Lage des Vogeleies im Uterus. Ibid., Bd. 8, p. 7 I3.

Pander, Ch.

I8I7 Historia metamorphoseos, quam ovum incubatum prior quinque diebus subit. Wiresburgi. The same in German and illustrated.-Beiträge zur Entwicklungsgeschichte des Hühnchens im Eye. Würzburg, I8I 7 . 
*Paris, J. A.

I8I I Some Remarks on the Physiology of the Egg. Trans. Linn. Soc. London, Vol. 10, p. 304.

Patterson, J. T.

I909 Gastrulation in the Pigeon's Egg. Jour. Morph., Vol. 20, p. 65.

I9 Io Studies on the Early Development of the Hen's Egg, Pt. I. Jour. Morph., Vol. 2I, p. IOI.

Pearl, R., and Surface, F. M.

I9II A Biometrical Study of Egg Production in the Domestic Fowl, Pt. II. Seasonal Distribution.

I9I4 Pt. III. Variation and Correlation in the Physical Characters of the Egg. U. S. Dept. Agricult. Bureau of Animal Industry, Bull. I Io.

Pearl, R., and Curtis, M. R.

I9I2 Studies on the Physiology of Reproduction in the Domestic Fowl, Pt. V. Data Regarding the Physiology of the Oviduct. Jour. Exp. Zoöl., v. I2, p. 99 .

I9I4 Pt. VIII. On Some Physiological Effects of Ligation, Section or Removal of the Oviduct. Ibid. v. I7, p. 394.

Petit, Mme.

I9oo Sur la sexualité des embryons de poule en rapport avec la forme de l'œuf. C. R. Assoc. Fr. Adv. Sc., Sess. 28, p. 276.

Pfeil, C.

I823 De evolutione pulli in ovo incubato. Dissert. Berolini.

Purkinje, J. E.

1825 Observata nonnulla ad ovi avium historiam ante incubationem.

1830 Symbolæ ad ovi avium historiam ante incubationem. Lipsiæ. (This is an enlarged second edition of the above with improved illustrations.)

Rabaud, E.

1908 La position et l'orientation de l'embryon de poule sur le jaune. Ar. Zoöl. Ex. Gen., 4e Sér., T. 9, p. I.

Riddle, $O$.

I9I I On the Formation, Significance and Chemistry of the White and Yellow Yolk of Ova. Jour. Mroph., v. 22, p. 455.

1912 Preliminary Chemical Studies on Male and Female Producing Eggs of Pigeons. Science, N. S., Vol. 35, p. 462.

I9I4 The Determination of Sex and Its Experimental Control. Bull. Am. Acad. Med., Vol. I5, No. 5 .

Ryder, J. A.

I893 The Mechanical Genesis of the Fowl's Egg. Proc. Am. Philos. Soc., v. 3I, p. 201.

Samter, J.

I853 Nonnulla de evolutione ovi avium donec in oviductum ingrediatur. Dissert. Halis.

\section{Sonnenbrodt,}

I908 Die Wachstumsperiode der Oöcyte des Huhnes. Ar. f. Mik. Anat., Bd. 72 , p. 4I 5 .

\section{Spangenburg, G.}

I813 Disquisitio inauguralis anatomica circa partes gentiales fœmineas avium. Goettingen. 


\section{Tarchanoff, J R.}

I884 Ueber die Verschiedenheiten des Eiereiweisses bei gefiedert geborenen (Nestflüchter) und nackt geborenen (Nesthocker) Vögeln u. s. w. Ar. f. d. ges. Phys., Bd. 33, p. 303.

\section{Taschenberg, $\mathrm{O}$.}

I885 Zur Frage über die Entstehung der Färbung der Vogeleierschalen. Zoöl. Anz., Bd. 8, p. 243.

* I894 Die Entstehung der Färbung der Vogeleier. Zoöl. Anz., Bd. I 7, p. 304. Thompson, Allen

I839? Article "Ovum," Cyclopedia of Anatomy and Physiology. I839-I847. Tredern, L. S. ab.

I808 Dissertatio inauguaralis medica sistens ovi Avium historiæ et incubationis prodromum. Jenæ.

Valentin, G.

r835 Handbuch der Entwickelungsgeschichte des Menschen u. s. w. Berlin.

Vicq d'Azyr

I805 Oeuvres (recueillies par J. L. Moreau) T. IV., p. 388 ss. “Fragmens sur l'anatomie et la physiologie de l'œuf."

*Wicke

Ueber das pigment in den Eischalen der Vögel. Naumannia.

Wickmann, $\mathrm{H}$.

*1893 Die Entstehung der Färbung der Vogeleier. Münster.

I895 Die Lage des Vogeleis vor und während der Geburt. Jour. f. Ornith., Bd. 44 , p. 8 I.

Wolff, C. F.

I764-1766 De formatione Intestinorum.

I8I 2 Ditto übersetzt von J. F. Meckel. 


\title{
STUDIES ON THE BIOLOGY OF PARA- COPIDOSOMOPSIS.
}

\author{
IV. The Asexual Larve. ${ }^{1}$
}

J. T. PATTERSON.

I. INTRODUCTION.

In 1906 Silvestri $^{2}$ reported in his paper on the development of Litomastix truncatellus the discovery of a curious type of larva, which he regards as asexual. According to Silvestri, the egg of Litomastix produces a thousand or more sexual larvæ and a variable number of these so-called asexual larvæ. The sexual larva undergoes metamorphosis and produces the adult male or female insect. The asexual larva, which dies without undergoing metamorphosis, is characterized by the absence of certain important organs, including the reproductive system.

Silvestri has suggested the possibility that these larvæ may be asexual because of the absence of germ cells. In studying the eggs of two monembryonic species he found that the so-called nucleolus is distributed to the germ cells alone, thus serving as a "keimbahm-determinant." The nucleolus is also present in the egg of Litomastix. In the early cleavage stages the nucleolus is included in one of the first four blastomeres, where it breaks down and its contents becomes evenly scattered throughout the cytoplasm. The presence of the nucleolar material retards the subsequent divisions of this blastomere. However, Silvestri was unable to follow the history of this particular cell beyond two divisions, that is, four cells. He suggests that during the course of the development of the polygerm, embryos which receive descendants of the single blastomere possessing the nucleolar

1 Contribution from the Zoölogical Laboratories of the University of Texas, No. 140.

${ }^{2}$ Silvestri, F., I906, “Contribuzioni alla conoscenza Biologica degli Imenotteri Parassiti. I., Biologia del Litomastic truncatellus." Ann. d. Regia Scuola Superiore di Agricoltura di Portici, Vol. VI., pp. I-5I. 
material become sexual larvæ, while those failing to receive such descendants become asexual larvæ.

Various suggestions have been offered to account for the presence of the so-called asexual larvæ in Litomastix. Some have suggested that they may not arise from the egg of Litomastix at all, but are larvæ belonging to an entirely different species. Thus Wheeler ('Io, p. 406) ${ }^{1}$ expresses doubt as to Silvestri's interpretation in the following language: "First, the asexual larvæ figured and described by this investigator are suspiciously like certain very young ichneumonid larvæ, and as their development is not satisfactorily traced to the same cellmasses from which the sexual Copidosoma larvæ arise, it is not improbable that the two larval forms really belong to two very different parasites. In other words, Silvestri's Plusia caterpillars were probably infested with ichneumonid in addition to Copidosoma larvæ. Second, I have been unable to find any larvæ of the asexual type in a number of American Plusia gamma caterpillars which were heavily infested with Copidosoma truncatellum. Third, as in many species of Chalcididæ larvæ of Silvestri's sexual type are able by their own endeavors to break down and assimilate the tissues of their host, it seems improbable that a single species should have developed a peculiar sexless and moribund larva for this particular purpose."

The subject clearly needs reinvestigation. In studying the biology of Paracopidosomopsis I have found the same sort of larvæ as those described by Silvestri for Litomastix. An opportunity is thus afforded to restudy the question. In the present paper only a brief history of the asexual larvæ will be given. As soon as sufficient material can be secured a detailed account of the cytology and embryology of both types of larvæ will be published.

The material used has been collected here at Austin during the last three years. The species, Paracopidosomopsis floridanus Ashmead, is very similar to Litomastix truncatellus. It lay its egg in the egg of the common cabbage looper, Autographra brassica. The parasitic egg develops in the body cavity or tissues

1 Wheeler, W. M., I9ro, "The Effects of Parasitic and Other Kinds of Castration in Insects," Jour. of Experimental Zoölogy, Vol. 8, pp. 377-438. 
of the Autographra caterpillar. By the time the caterpillar reaches the stage for pupation, the larval parasites consume its entire contents, leaving only the skin of the host which later hardens to form the mummified carcass containing the parasitic pupæ. Since the parasites readily emerge in the laboratory the species is very favorable for experimental studies.

Whenever the infection is heavy an abundance of material can be secured from the field. But in order to avoid the possibility of the host egg or larva becoming infected by a species other than Paracopidosomopsis, I have used almost exclusively material reared in the laboratory under experimental control. The only exception in this paper is Fig. I2, Plate II.

In all of the experiments the moth eggs have been protected from parasites by having the moths lay their eggs under a belljar. The fresh eggs thus obtained are then parasitized. The female parasite has been permitted to make but a single oviposition in each moth egg. The parasitized eggs and the larvæ developing from them have been protected from subsequent infection by keeping them in a closed vessel from which all parasites were scrupulously excluded. Under these conditions of protection, I find that the parasitic egg produces asexual as well as sexual larvæ. These curious larvæ develop irrespective of whether or not the female parasite laying the egg is virgin or impregnated.

From the standpoint of experimental work, the material presents one difficulty. In a previous paper, I have shown that the female, in about two cases out of three, deposits two instead of one egg at a single oviposition. It is frequently difficult, especially in late stages, to determine in a given parasitized caterpillar whether one is dealing with a case involving the product of one or of two parasitic eggs. In early stages this difficulty seldom presents itself, because if two polygerms are present they nearly always lie some distance apart in the tissues of the host.

The age of any stage, referred to in this paper, is based upon the time of oviposition. There is, however, considerable variation in the rate of development of different eggs. Furthermore, temperature greatly influences the rate of development. In August and September about 28 to 30 days elapses between the 
laying of the egg and the emergence of the adult insects; whereas in the cooler months of October and November, it takes about 40 to 45 days.

\section{The Early Polygerm Stage.}

It will be sufficient, for the purposes of this paper, to give only a brief statement concerning the early development of the egg. The freshly deposited egg is a pear-shaped structure, with a large conspicuous nucleus situated toward the anterior or narrower end, and a deeply staining nucleolus lying at the posterior or broad end. Immediately after the egg is deposited, the nucleus undergoes the typical maturation divisions. The first polar body nucleus divides simultaneously with the second maturation division. There is thus produced an egg nucleus and three polar-body nuclei. The former then moves to the broad end of the egg, and whether fertilized or not, produces the cleavage cells. One of the first four blastomeres receives the nucleolus, the presence of which somewhat retards the subsequent divisions of this particular cell. By the time the other three blastomeres have produced about twenty-four cells, the one containing the nucleolar substance has produced but four. Beyond this point its history can not be followed. All of these early blastomeres constitute the embryonic cells. They occupy the posterior twothirds of the egg.

In the meantime, the polar-body nuclei fuse to form a single polar nucleus, which continues to divide until the protoplasm of the anterior end of the egg is filled with nuclei. The anterior third of the egg thus becomes syncytial in character, and may be called the polar region. In slightly later stages the polar region completely surrounds the mass of embryonic cells, and in stages still more advanced, it forms a nucleated membrane.

About seventy hours after oviposition, the nucleated membrane begins to invade the embryonic cells by the formation of trabeculæ, which divide the embryonic cells into several groups, or primary masses (Fig. I). During the formation of these masses, or very shortly thereafter, the young polygerm elongates in the direction of the long axis of the egg (Fig. 2). In addition to the nucleated membrane, each primary embryonic mass develops a 
second envelope, which lies just inside the nucleated membrane. Apparently, this inner envelope is formed from the peripheral layer of cells of the embryonic mass (Fig. 3). The primary embryonic masses produce secondary masses by fission. A very clear case of division is seen in Fig. 8, on the right.

\section{Origin of the Asexual Larve.}

The first sign of asexual larvæ appears in young polygerms between seventy-five and eighty hours old. One of the youngest stages observed is shown in Fig. 3. An asexual embryo lies at the upper end of the figure, and is distinguishable from the primary masses by two features of its organization. First, the asexual embryo is composed of a large number of relatively small, closely packed cells, whereas a primary mass is composed of a few large cells, showing no definite arrangement. Second, the inner of the two envelopes surrounding the embryo is decidedly hicker than the corresponding membrane of a primary mass. Both of these features become more evident in slightly older stages, such for example, as that shown in Fig. 4. In this specimen the asexual embryo stands in striking contrast to the rest of the polygerm. Furthermore, the constriction of the nucleated membrane, or outer envelope, has all but cut off the embryo from the primary masses. A similar condition is seen in Fig. 5 .

At this point it will be well to recall Silvestri's account of the origin of the asexual larvæ in Litomastix. The polygerm of Litomastix, soon after the nucleated membrane is established, begins to show differentiation into two distinct regions. The anterior region is made up of large and small cells, while the posterior region is composed of small cells only. A constriction appears in the nucleated membrane, which finally separates these two regions. Silvestri names the anterior region the massa germinigena, and the posterior the massa monembrionale. The latter subsequently differentiates into a single asexual larva. In the course of further development, the massa germinigena gives rise to a few secondary monembryonal masses, which differentiate into asexual larvæ, and to a large number of other masses. This is accomplished by constrictions in the polygerm. The masses continue to multiply by constrictions, and may from 
time to time produce a few asexual embryos; but a large majority of them differentiate into sexual embryos.

Some phases of the development of Paracopidosomopsis are directly comparable to certain stages of Litomastix. The formation of the primary masses and their subsequent mode of multiplication is very similar to the history of the massa germinigena. The chief difference is the early formation of a monembryonal mass in Litomastix, for which there is no counterpart in Paracopidosomopsis. According to Silvestri the young polygerm always differentiates into a monembryonal mass and the massa germinigena. In the American species a single asexual embryo may be found at an early stage (Figs. 3, 4, 5), but this is by no means the universal rule. In Figs. 6, 7, 8 are shown three well-developed polygerms in which no asexual embryos have as yet appeared. It is not certain whether such polygerms later produce asexual larvæ, although the evidence seems to indicate that at least some of them do. In some cases two or more asexual embryos may develop simultaneously in the very young polygerm. The specimen on the right of Fig. 9 has two such embryos, and Fig. II illustrates a similar case. The polygerm shown in Fig. I3 has given rise to four asexual embryos, all in the same stage of development, but situated in different parts of the mass.

These facts indicate clearly that the polygerm of Paracopidosomopsis may give rise to one or more asexual embryos at a very early stage of differentiation, but there is no such regularity in the formation of a single monembryonal mass as reported by Silvestri for Litomastix.

\section{Dissociation of the Polygerm.}

We have already mentioned the fact that the primary masses divide to produce the secondary masses. An early phase of this process is seen in Fig. 6. The primary mass at the extreme left and the one lying on the lower side has each undergone several divisions. There are at least four secondary masses visible in the median section of each primary center. In a still younger stage, Fig. 8 , the primary mass on the right is just completing the first division. At this stage of development each secondary mass consists of one or more large central cells and an indistinct 
peripheral layer of smaller cells. Surrounding the mass is a thin envelope formed from the trabeculæ of the nucleated membrane. The large central cells are clearly the embryonic cells proper.

The multiplication of secondary masses to produce other masses continues for a long period, at the close of which the final products of division develop into embryos. However, during the course of development, usually early in the period of multiplication, the polygerm fragments or dissociates, the secondary masses becoming widely scattered throughout the body cavity of the caterpillar. The point at which dissociation takes place varies greatly in different cases. It may occur at the close of the third day, or it may be delayed until as late as the tenth or eleventh day. Indeed, in some cases, the polygerm does not completely dissociate until the larvæ are ready to be set free in the body cavity of the host. Apparently, the dissociation is in part controlled by the relation of the polygerm to the host tissues. If the polygerm lies free in the body cavity, or in loose tissue, dissociation will occur very early; but if it is imbedded in fat or other dense tissue, the dispersal of the secondary masses may be greatly delayed.

The polygerm on the left of Fig. 9, although only seventyseven hours old, has already begun to fragment. Several secondary masses lie some distance from the main body of the polygerm. Two of these appear in the photograph. The polygerm seen in Fig. $\mathrm{I}_{3}$ is ninety-five hours old, and lies free in the body cavity. Dissociation is well advanced, and secondary masses are widely dispersed. In addition to the secondary masses, it has formed four asexual embryos at as many different points. The polygerm in Fig. I I is eleven days old. It was dissected from the fat tissue of the host. It contains a large number of secondary masses, some of which are beginning to break loose from the main mass, and two conspicuous asexual embryos. These few cases will serve to show the variation in the time at which dissociation begins.

V. Development and Fate of the Asexual Larve.

While some polygerms produce asexual embryos at a very early stage (Figs. 3, 4, 5, 9, I3), nevertheless the majority of such 
embryos do not appear until after dissociation has taken place. The production of asexual larvæ in a given polygerm is not confined to a single period of development, but is a continuous process, extending from the third to about the fifteenth day. Sections of practically every polygerm from twelve to fourteen days old will show asexual individuals in various stages of development, from young embryos to fully developed larvæ.

The method of their development in the American species is very similar to that for Litomastix as described by Silvestri. The main difference is that they frequently appear in groups, instead of arising singly from certain of the secondary masses. This is also true for some of the early cases (Figs. 9, II). Fig. I4 is a section passing through a group of asexual embryos imbedded in adipose tissue. In the upper right-hand corner of the figure is a group of secondary masses about on the point of developing into sexual embryos. They are easily distinguishable from the asexual embryos by their comparatively small size. Several other series show this same condition. Single embryos or small groups of two or three do, however, appear in some of the series.

After the period of multiplication of secondary masses is closed, that is in stages fourteen or fifteen days old, the body cavity of the host contains many groups of asexual embryos (Figs. I5, I6, I2) as well as groups of young asexual larvæ. In each of two series a group of ten or twelve individuals was found. There are also found free asexual larvæ (Figs. 20, 21, 22), and some that are on the point of being set free from the capsule (Fig. I8). That single asexual larvæ may develop in conjunction with a group of sexual embryos is clearly evident in two instances. In Fig. I7 a young asexual larvæ is closely associated with a group of sexual embryos, and in Fig. I9 a large asexual larvæ, just freed from its capsules, is still attached to a mass of embryos.

The frequent appearance of asexual embryos or larvæ in groups suggests that, like the sexual embryos, the individuals of a group have a common origin, probably arising through the division of a single secondary mass.

Since one cannot follow the course of development of a single egg, but must depend upon series of sections, it is impossible to determine whether every polygerm eventually produces asexual 
larvæ. Dissections of a large number of infected caterpillars, twelve to fifteen days old, reveal the presence of asexual larvæ in nearly every case. It is probable that in a few cases no asexual larvæ are developed. It is also difficult to determine the exact number of asexual larvæ produced by a given egg. This is due to the fact that these larvæ are formed continuously from ths third to the fifteenth day, and those first developed degenerate before the last ones appear. The smallest number of larvæ found was one, the largest fifteen. Careful dissections of a series of infected caterpillars reared in the laboratory gave the following data on asexual embryos and larvæ:

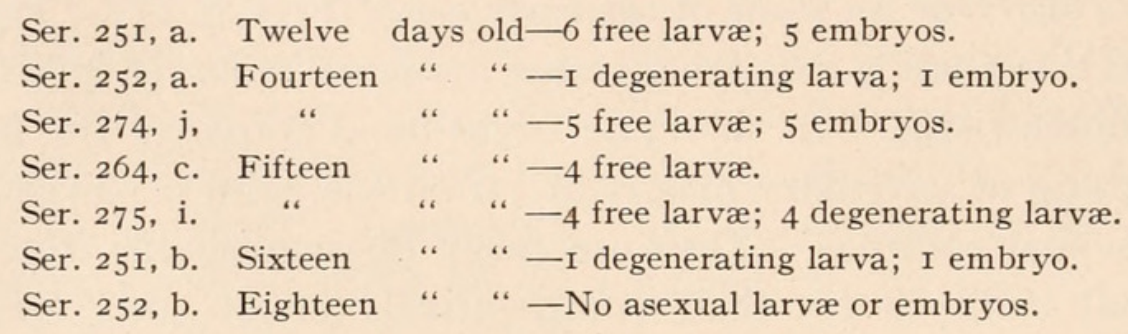

These data indicate that not more than twelve to fifteen asexual larvæ are produced by a single egg. They also show the period in which these larvæ are developed. The youngest stage containing free larvæ was twelve days old, while the oldest was sixteen days. The asexual larvæ have all degenerated by the eighteenth day. This conclusion has been verified by an extensive study of infected caterpillars from the field. No asexual larvæ have been found in caterpillars whose size indicated that they were eighteen days or older.

The general appearance of the fully developed asexual larva is shown in Figs. 20-22. I have not worked out the details of their organization, but it is clear from a study of entire mounts and sections that the reproductive system is absent. Whether, as in Litomastix, the respiratory system, circulatory system, and malpighian tubules are absent, I have not determined.

The asexual larvæ apparently do not live more than a very few days after being set free in the body cavity, probably not over three days. Free larvæ first appear on the twelfth day, and degenerating specimens are found on the fifteenth day. The last larvæ escape from their envelopes on the sixteenth day, and disappear on the eighteenth day. Without exception all asexual 
larvæ degenerate. The beginning of degeneration is marked by a foreshortening and twisting of the body (Figs. 23-25). The larva then becomes immobile and soon disintegrates (Fig. 26). So far as I can observe, the larvæ perform no function. There is no evidence that they break down the tissues of the host in preparation for assimilation by the sexual larvæ. They disappear at least a week before the sexual larvæ become free agents.

Whatever may be the underlying cause of the development of these non-viable larvæ, there is certainly no doubt as to the fact that they are formed from the egg of Paracopidosomopsis. This fact is established by the results obtained from controlled experiments in which all other parasitic species have been excluded, and by tracing their origin back to the beginning of their development in the young polygerms.

Austin, Texas,

June 20, I9I 8. 


\section{Explanation of Plate I.}

FIG. I. A median longitudinal section of a young polygerm. The egg from which this polygerm developed was about 73 hours old. The egg was laid by a fertilized female. $\times 385$.

FIG. 2. From the same lot as the preceding, but slightly more advanced in development. $\times 379$.

FIGS. 3-I0. All from sections of larvæ on the point of hatching. About 77 hours old. The eggs were laid by fertilized females. $\quad \times 389$.

FIG. 3. Longitudinal section of polygerm, showing a young asexual embryo at upper end.

FIG. 4. Same as preceding, with asexual embryo at lower end.

FIG. 5. A polygerm with asexual embryo on the right.

FIG. 6. A polygerm showing no axesual embryo.

FIG. 7. Transverse section of polygerm, showing no asexual embryo.

FIG. 8. Same as preceding. On the right is seen an embryonal mass in the act of dividing.

FIG. 9. Two polygerms in tissue of host. The one on the left has undergone partial dissociation, while the one on the right has not yet dissociated. The latter shows two asexual embryos at the upper end.

FIG. Io. Part of a dissociated polygerm, showing a well-developed asexual embryo and four embryonal masses. 


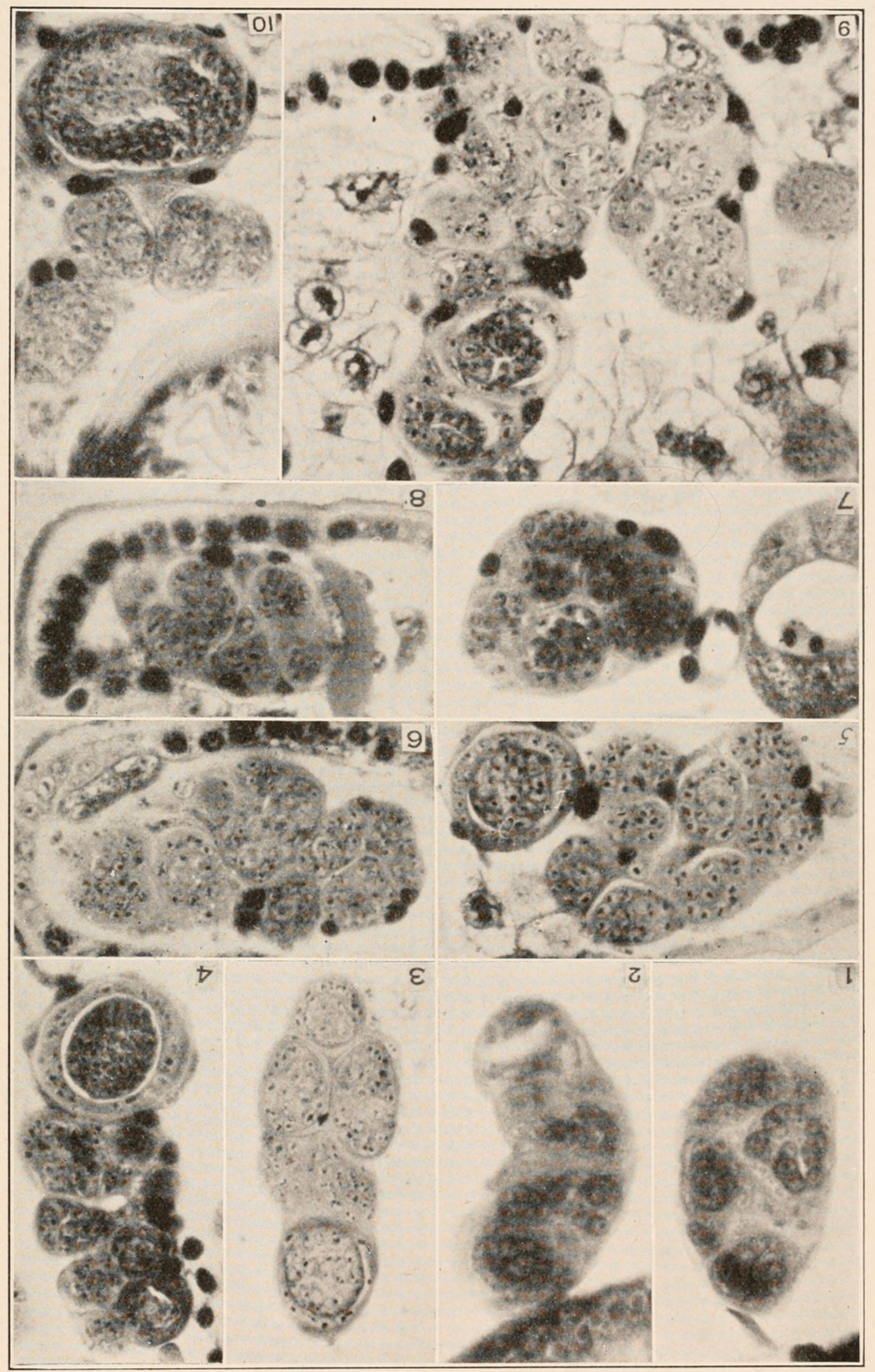






\section{Explanation of Plate II.}

FIG. II. Longitudinal section of an advanced polygerm removed from the adipose tissue of a I2-mm. caterpillar. The polygerm is II days old. The egg was laid by a fertilized female. Two large asexual embryos are shown in the upper end of the figure. $\times$ I48.

FIG. I2. A mass of sexual embryos. One of several masses removed from the body cavity of a $30 \mathrm{~mm}$. caterpillar taken from the field. $\times 4 \mathrm{I}$.

FIG. I3. Part of a longitudinal section of a polygerm in the body cavity of $5 \cdot 5$ $\mathrm{mm}$. caterpillar. The polygerm has undergone almost complete dissociation. One of the four asexual embryos present in this polygerm is seen at the right. Egg laid by fertilized female. 95 hours old. $\times 490$.

FIG. I4. Part of a dissociated polygerm, showing a group of seven asexual embryos, and a group of embryonal masses in the upper right-hand corner. All are embedded in fat tissue. The polygerm is 9 days and 23 hours old. $\times 136$. 


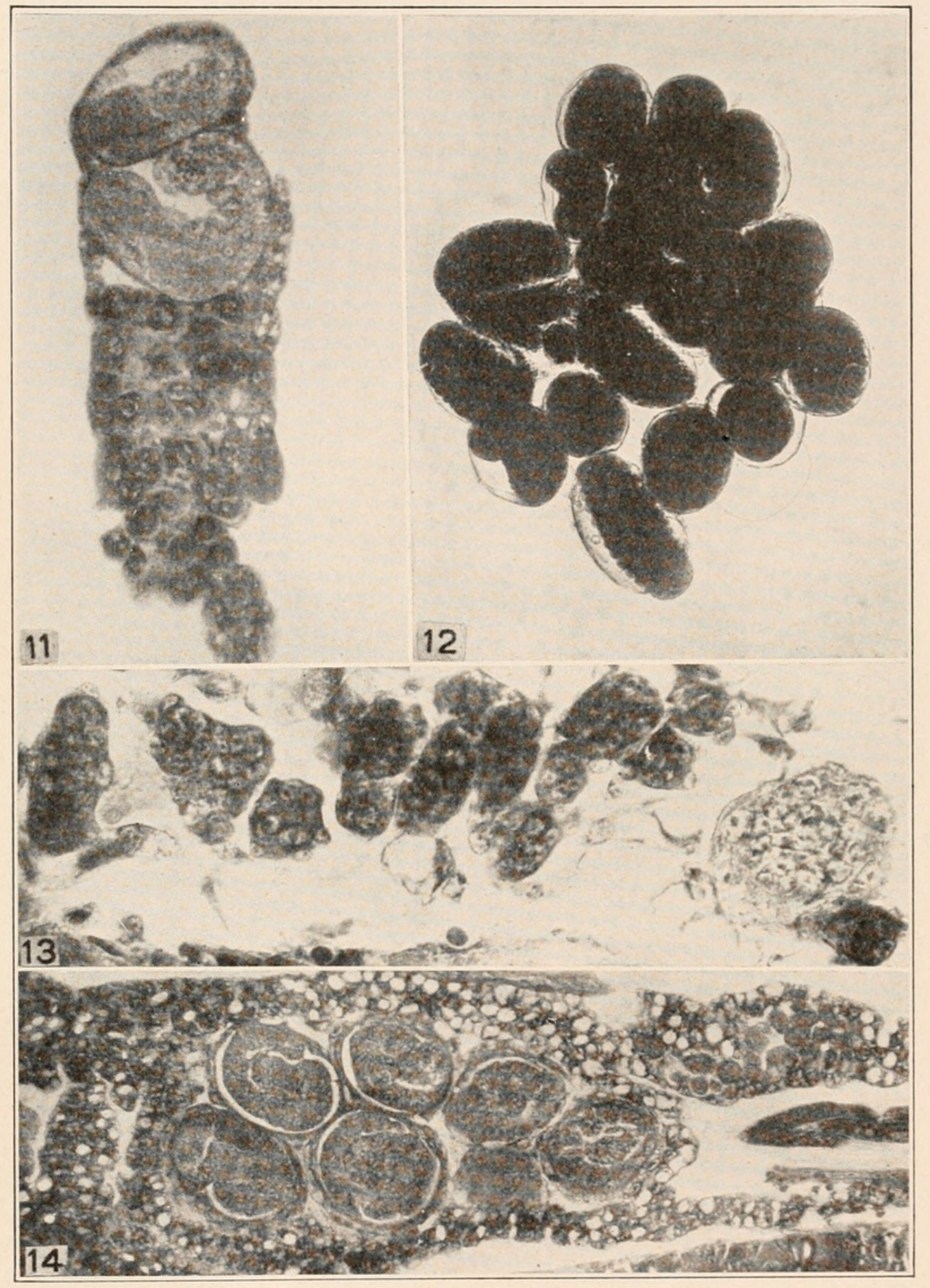

J. T. PATTERSON. 




\section{Explanation of Plate iII.}

Figs. I5, I6, I9, 22-26 are from eggs (or egg) laid by an unfertilized female. The specimens were taken from the body cavity of a half-grown caterpillar I5 days after the eggs had been deposited. The body cavity contained 4 normal and 4 degenerate asexual larvæ, in addition to many masses of sexual embryos. Figs. I 7, I 8,20 and 2I are from eggs (or egg) laid by a fertilized female. The specimens were removed from the body cavity of a $20-\mathrm{mm}$. caterpillar, I4 days after the eggs had been deposited. There were found in the body cavity of the caterpillar 6 free asexual larvæ and 4 still enclosed in their membranes, besides many masses of sexual embryos.

Figs. 15, I6. Two masses of sexual embryos. $\times$ ioo.

FIG. I7. Mass of sexual embryos with asexual embryo in capsule. $\times$ Ioo.

FIG. I8. Asexual larvæ in capsule. $\times$ ıоo.

FIg. I9. Asexual larva free from capsule but still adhering to mass of sexual embryos. $\times 88$.

FIGS. 20-22. Three asexual larvæ. $\times 88$.

FIGS. 23-26. Four degenerating asexual larvæ. $\times 88$. 


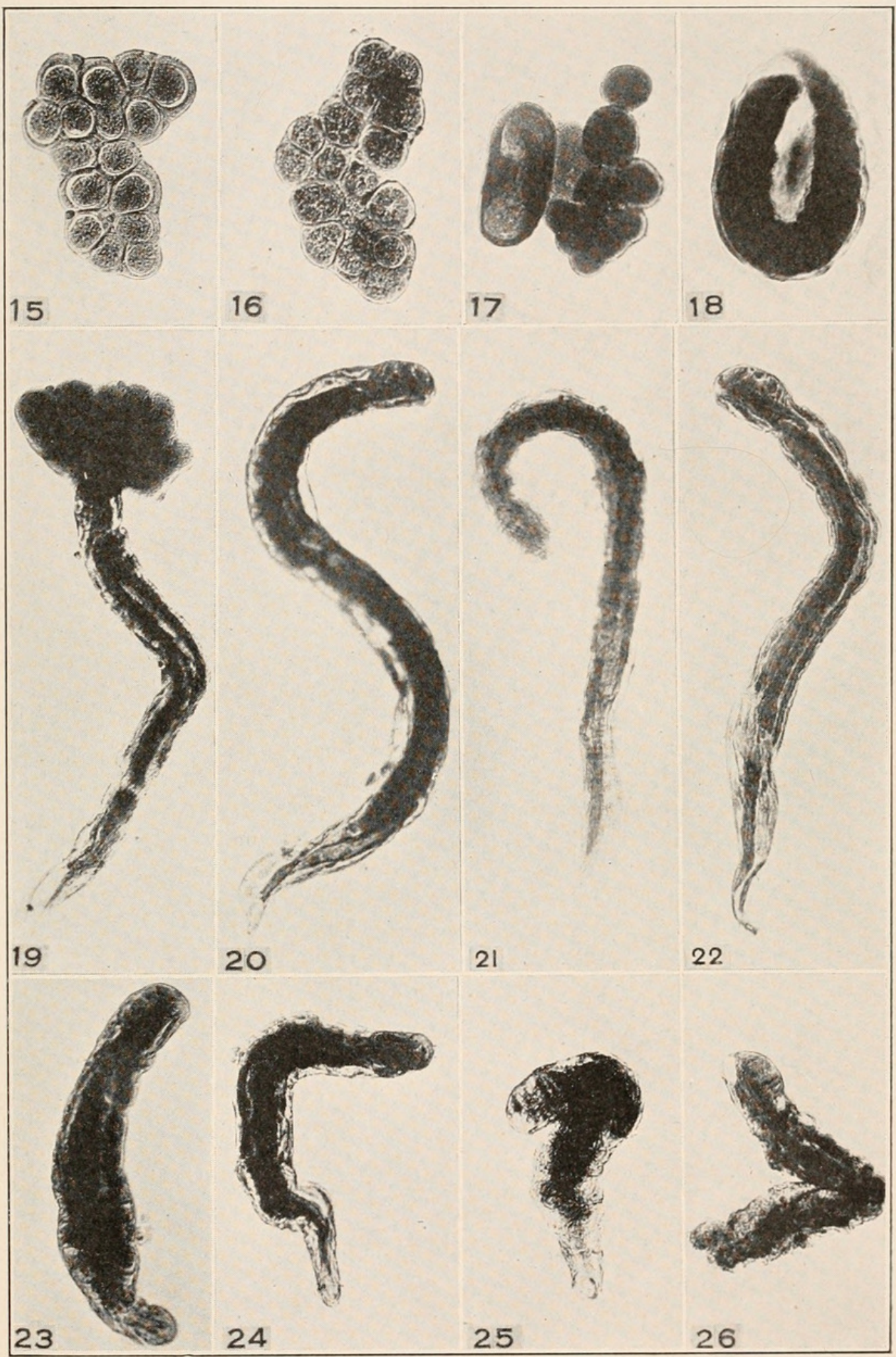

J. T. PATTERSON. 





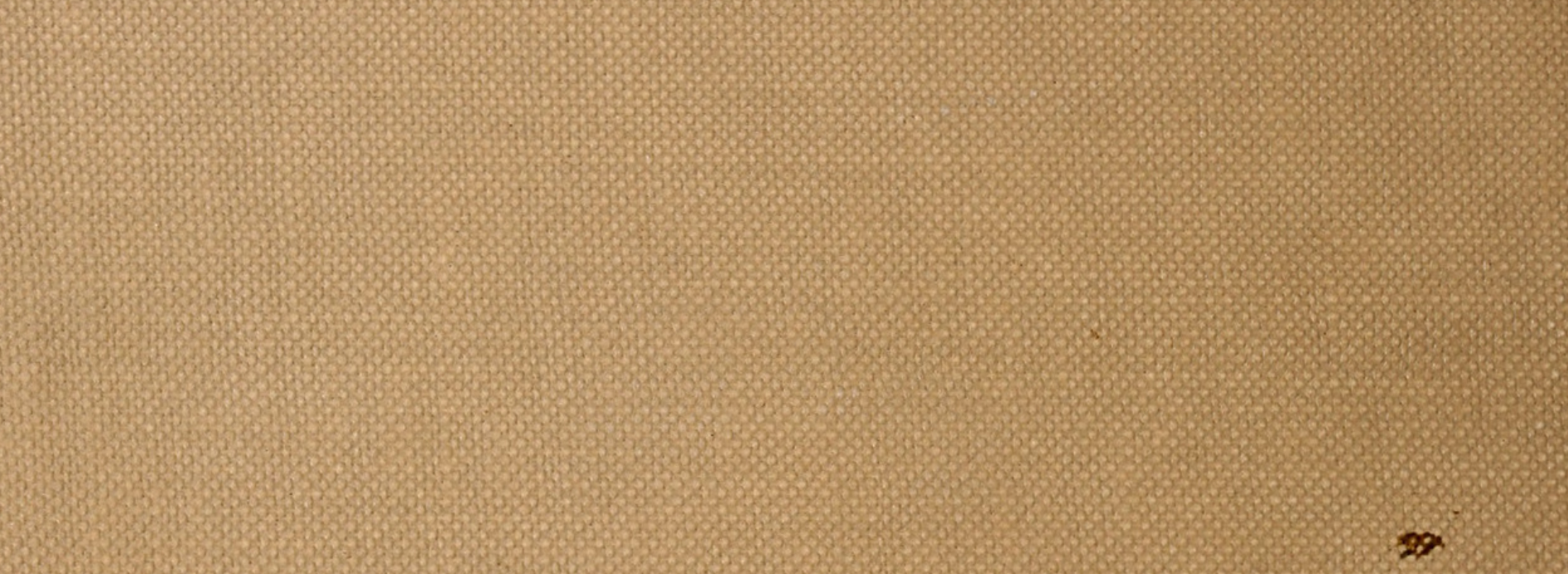
88 


\section{$2 \mathrm{BHL}$ Biodiversity Heritage Library}

Packard, Charles. 1918. "THE EFFECT QF RADIUM RADIATIONS ON THE DEVELOPMENT OF CHAeTOPTERUS." The Biological bulletin 35, 50-70. https://doi.org/10.2307/1536403.

View This Item Online: https://www.biodiversitylibrary.org/item/16928

DOI: https://doi.org/10.2307/1536403

Permalink: https://www.biodiversitylibrary.org/partpdf/13783

\section{Holding Institution}

MBLWHOI Library

\section{Sponsored by}

MBLWHOI Library

\section{Copyright \& Reuse}

Copyright Status: NOT_IN_COPYRIGHT

This document was created from content at the Biodiversity Heritage Library, the world's largest open access digital library for biodiversity literature and archives. Visit BHL at https://www.biodiversitylibrary.org. 